\title{
Impacts on terrestrial and streamside herpetofauna by mountaintop removal mining in southern West Virginia
}

Jennifer Mravintz Williams

West Virginia University

Follow this and additional works at: https://researchrepository.wvu.edu/etd

\section{Recommended Citation}

Williams, Jennifer Mravintz, "Impacts on terrestrial and streamside herpetofauna by mountaintop removal mining in southern West Virginia" (2003). Graduate Theses, Dissertations, and Problem Reports. 1938.

https://researchrepository.wvu.edu/etd/1938

This Dissertation is protected by copyright and/or related rights. It has been brought to you by the The Research Repository @ WVU with permission from the rights-holder(s). You are free to use this Dissertation in any way that is permitted by the copyright and related rights legislation that applies to your use. For other uses you must obtain permission from the rights-holder(s) directly, unless additional rights are indicated by a Creative Commons license in the record and/ or on the work itself. This Dissertation has been accepted for inclusion in WVU Graduate Theses, Dissertations, and Problem Reports collection by an authorized administrator of The Research Repository @ WVU.

For more information, please contact researchrepository@mail.wvu.edu. 
Impacts on Terrestrial and Streamside Herpetofauna

by Mountaintop Removal Mining in Southern West Virginia

\author{
Jennifer Mravintz Williams
}

\title{
Dissertation
}

Submitted to the Graduate Faculty of the

Davis College of Agriculture, Forestry, and Consumer Sciences

West Virginia University

In Partial Fulfillment of the Requirements for

the Degree of Doctor of Philosophy

in Forest Resource Science

\author{
Petra Bohall Wood, Ph.D., Chair \\ James Anderson, Ph.D. \\ Gerry Hobbs, Ph.D. \\ Tom Pauley, Ph.D. \\ Jeff Skousen, Ph.D.
}

Morgantown, West Virginia

2003

Keywords: Herpetofauna, Mountaintop Removal Mining, Valley Fills, Tree Removal, Soil Excavation, Soil Compaction, Reclaimed Grasslands, Reclaimed Shrub-pole Habitat 


\author{
ABSTRACT \\ Impacts on Terrestrial and Streamside Herpetofauna \\ of Mountaintop Removal Mining in Southern West Virginia
}

Jennifer Mravintz Williams

Mountaintop removal mining, a mining technique used in the Appalachian Mountains of West Virginia and nearby states, converts mature forests to grassland and shrub-pole habitats. I sampled terrestrial herpetofauna using drift fences with pitfalls and funnel traps from 2000-2002 to evaluate habitat use of unmined native habitat (intact forest), habitat on reclaimed mountaintop removal mines (reclaimed grassland, reclaimed shrub-pole habitat, and fragmented forest), and early successional off-mine habitats that were created by other types of disturbance and were structurally similar to reclaimed grasslands and reclaimed shrub-pole habitats. I searched transects in valley fill and reference streams from 2001-2002 to evaluate impacts of valley fill construction on streamside salamanders and sampled coverboard transects that traversed reclaimed habitats and adjacent forests from 2001-2002 to determine edge effects of reclaimed mine habitat on salamanders.

Salamander relative abundance levels were lower in reclaimed habitats in all three components of this study and increased into forests with increasing distance from reclaimed habitat edges. Snake abundance and species richness were higher in reclaimed habitats. Creation of grassland and shrub-pole habitats adversely affected less mobile habitat specialists and benefited more mobile habitat generalists. Anuran species richness and abundance did not differ among treatments; lizards and turtles were not captured in levels sufficient to conduct statistical analyses.

Soil compaction on and reduced vertical structure of reclaimed mine surfaces may deter salamanders from burrowing into minesoils. Reduced vertical structure of reclaimed habitats may make them too dry for salamanders. Higher small mammal abundance on reclaimed habitats could have favored snakes. More silt cover in valley fill streams may have reduced available habitat for stream salamanders.

Time since disturbance varied from 10-28 years in reclaimed habitats. Salamander populations in these reclaimed habitats have not reached abundance levels found in intact forests. Past research has shown that salamander populations in clearcut areas may recover and reach pre-cut abundance levels in 15-70 years. Both mountaintop removal mining and clearcutting involve tree removal. However, tree removal associated with mountaintop removal mining covers a larger area and is coupled with large-scale soil removal. These features may mean that salamander populations on reclaimed mines will take as long or longer than 15-70 years to reach levels of intact forests. 


\section{Acknowledgements}

Funding for this study was provided by the United States Environmental Protection Agency, West Virginia State Legislature, West Virginia Division of Natural Resources, Cooperative Research Units, U.S. Geological Survey, and West Virginia University Research Corporation. Drs. James Anderson (wildlife biology), Gerry Hobbs (statistics), Thomas Pauley (herpetology), and Jeffrey Skousen (mine reclamation) provided advice on study design and input on other aspects of this project. Dr. George Seidel gave invaluable statistical guidance throughout this project. I thank Arch Coal and employees at Hobet-21 (particularly John McDaniel and Larry Emerson), Dal-Tex, and Cannelton Mines, in addition to numerous landowners in the study area, for property access, information included in this report, and tours of the mine properties. John McDaniel, Eric Richmond, and Steve Houchins were very helpful in finding off-mine grassland and off-mine shrub-pole sampling points. Arc Land Company provided field housing, which Ron Vermillion was particularly helpful in coordinating. Gary

Williams made valuable editing comments and suggestions on earlier drafts of this report. Katie Weakland, Gary Williams, and Scott Bosworth assisted with creation of maps using ArcView GIS. Numerous people assisted with field work including Frank Ammer, John Anderson, Shelby Bacharach, Scott Bosworth, Andrew Brown, Josh Carlson, Amanda Carroll, H. Doug Chamblin, Tim Dellinger, Rob Dempsey, John Edwards, Elizabeth Goldsmith, John Hartman, Joshua Homyack, Megan Jones, Jessica Kapp, Lisa Kendall, J. Jae Martin, Shana Marchetti, Todd McCoy, Robin Pumphrey, Andrew Roberts, Josh Scullen, Jon Simmons, Brent Sparks, Kelly Warren, Katie Weakland, Gary Williams, Petra Wood, and Jason Woolard. I also extend extra special thanks to Amanda Carroll and Doug Chamblin. They are wonderful friends and contributed some serious sweat and labor for the better part of a year on this project; they were both always a lot of fun too. I also want to give a special thank you to Shelby Bacharach for her good nature and hilarity and for never once complaining and to Tim Dellinger for all of his good ideas, attention to detail, excellent organizational skills, and for doing the job right every time. Scott and Michelle Bosworth are great friends; they've have helped me out countless times. Scott was always supportive and understanding of the trials and tribulations of being a grad student and I feel privileged to know such an incredibly nice and funny guy. Kim Bjorgo went out of her way to make me feel welcome at WVU. She introduced me to fellow graduate students, showed me around Morgantown and the campus, and did many other kind acts to make 
my first semester at WVU a lot easier. Jason Freund, Katie Weakland, Rebecca and Brian Smith, and Melody Danley have also been very supportive during my tenure at WVU and I am glad for their friendship. Becky Nestor extended her assistance, support, and good humor on countless occasions. Dr. Skousen gave me a boost of confidence and some words of encouragement when I needed it most. Dr. Pauley, through his kindness and enthusiasm for herping, showed me how to really make a difference in this profession and also gave positive feedback that really meant a lot to me. The mountaintop crew has been really great these past several years; we've made a lot of good memories and went through a lot together on this project. We'll probably never forget the proper way to hatch out a robin egg or the best way to make $\$ 10 / \mathrm{hr}$. My family and friends have really kept me going throughout this project and I appreciate all of their unwavering support and encouragement. Petra Wood deserves much recognition for her ability to juggle five million students and projects, for pushing me to be a better student and researcher, for her excellent editing skills, for her patience and kindness when I was unclear about anything, for her tireless efforts throughout this project, for serving as my advisor, and for her sincere desire to have all of her students succeed. Last and most important, I want to extend the hugest thank you ever to my husband, Gary, for everything. I really feel that I owe this degree to him. Without his support, love, encouragement, and for his believing in me even when I was unable to, I do not think that I would have made it this far and I truly am eternally grateful for all of this. I know how lucky I am to have someone so wonderful in my life. 


\section{TABLE OF CONTENTS}

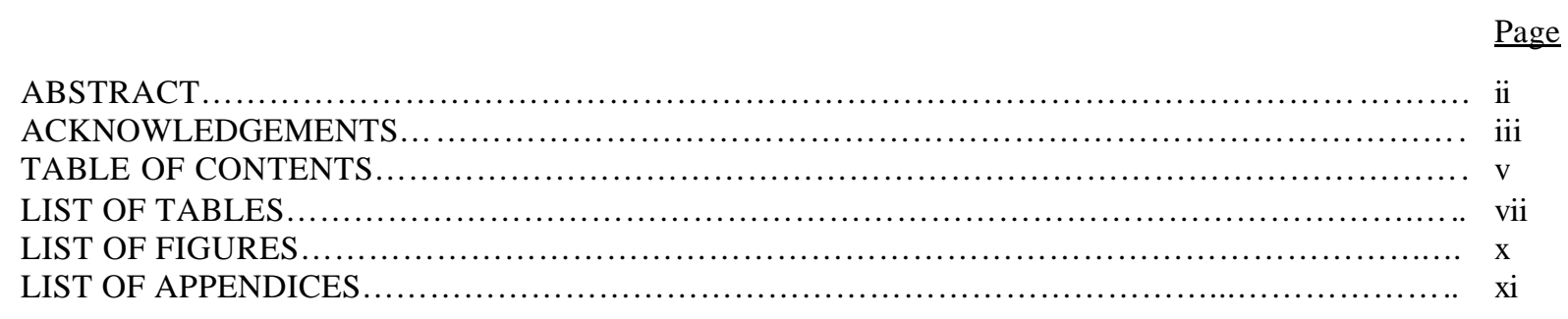

\section{CHAPTER 1: INTRODUCTION AND LITERATURE REVIEW}

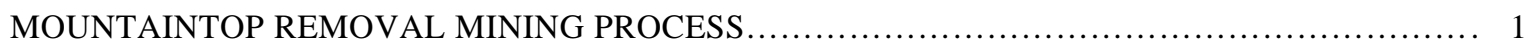

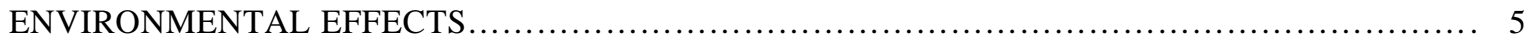

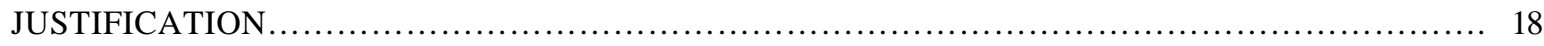

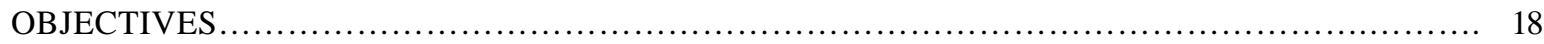

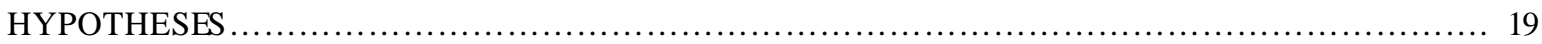

DESCRIPTION OF STUDY AREA

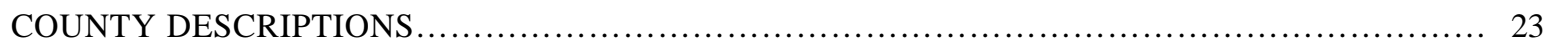

CHAPTER 2: MOUNTAINTOP REMOVAL MINING AND ITS IMPACTS ON TERRESTRIAL HERPETOFAUNAL COMMUNITIES IN SOUTHERN WEST VIRGINIA

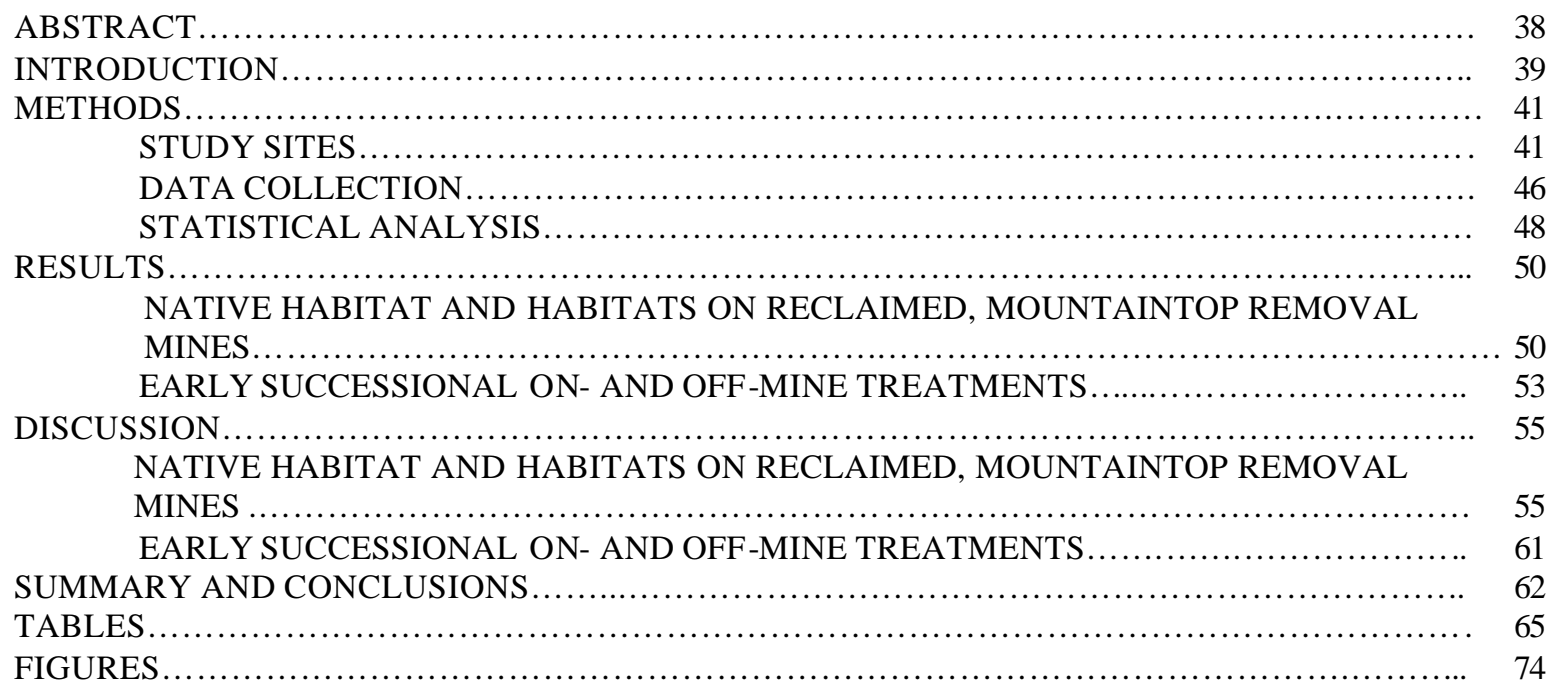

CHAPTER 3: IMPACT OF HEAD-OF-HOLLO W VALLEY FILL CONSTRUCTION ON STREAMSIDE SALAMANDERS IN SOUTHERN WEST VIRGINIA

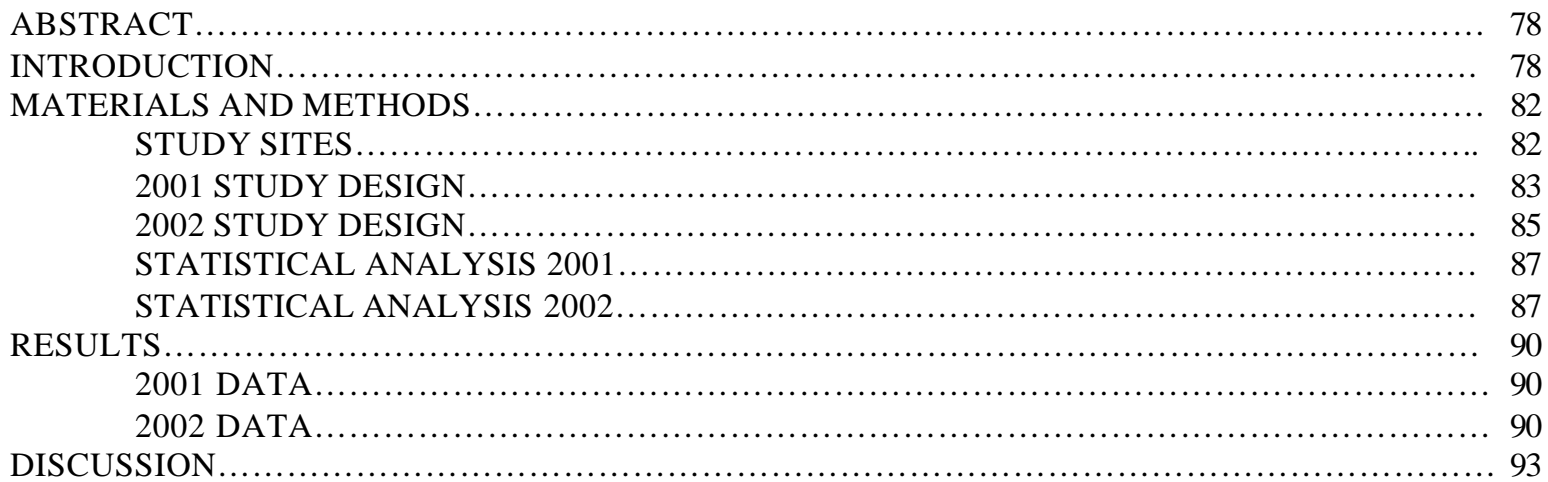


TABLES

CHAPTER 4: EDGE EFFECT OF RECLAIMED MOUNTAINTOP REMOVAL MINE HABITAT ON SALAMANDERS

$\underline{\text { Page }}$

ABSTRACT

109

INTRODUCTION

109

METHODS COVERBOARD TRANSECTS.

111

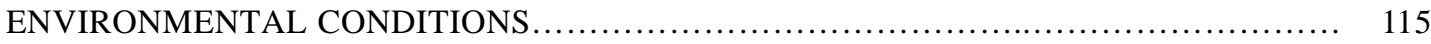

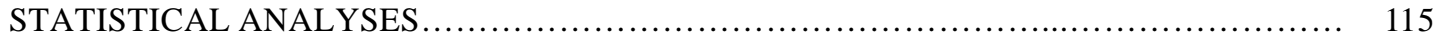

RESULTS.

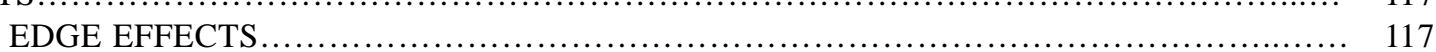

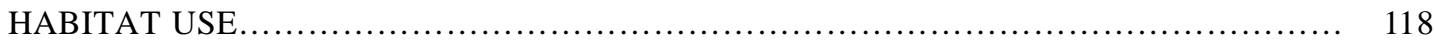

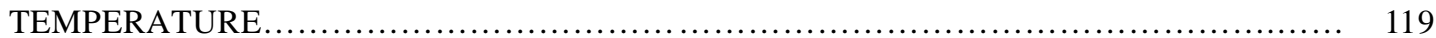

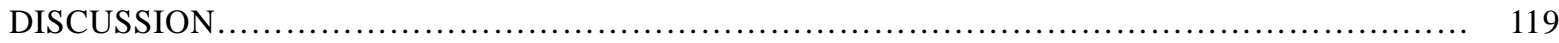

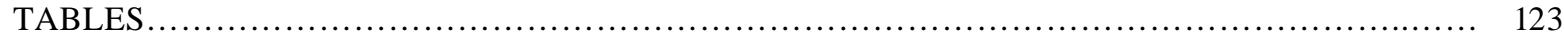

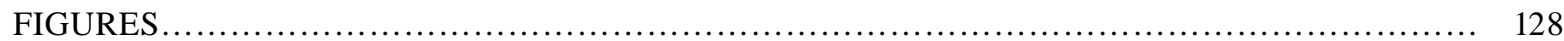

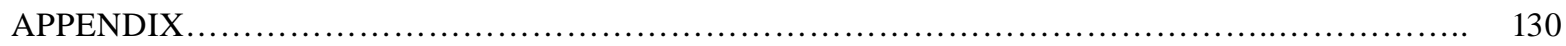

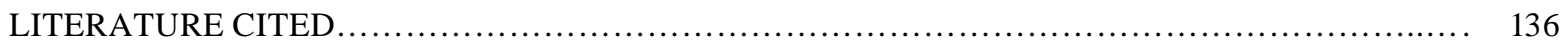

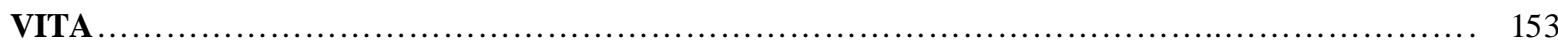




\section{LIST OF TABLES}

\section{CHAPTER 2:}

Table 1. Estimated age (in 2002) and elevation of reclaimed grassland, reclaimed shrub-pole, fragmented forest, and intact forest treatments having drift fence arrays for sampling herpetofauna and total area (in 2002) of each treatment at each mine site. A dashed line indicates that data were not applicable to that treatment or mine site.

Table 2. Watersheds and stream drainages with drift fence array sampling points by treatment in 3 watersheds in southern West Virginia.

Table 3. Number of individuals $(\mathrm{N})$ of herpetofaunal species captured in drift fence arrays and percent of drift fence arrays $(\%)$ at which a species was captured in reclaimed grassland $(\mathrm{n}=3)$, reclaimed shrub-pole $(n=3)$, fragmented forest $(n=3)$, and intact forest $(n=3)$ treatments on and near mountaintop removal mines in southern West Virginia, 2000-2002.

Table 4. Herpetofaunal species richness and relative abundance (adjusted per 100 array nights and per trap effort) from drift fence arrays in reclaimed grassland, reclaimed shrub-pole, fragmented forest, and intact forest treatments in a reclaimed mountaintop removal mine landscape in southern West Virginia, 2000-2002. Within a row, means with the same letters are not different at á $=0.10$ (Waller Duncan K-ratio t-test).

Table 5. Number of individuals and species $(\mathrm{N})$ and proportion of total individuals and total species (\%) of herpetofaunal groups captured in drift fence arrays in grassland, shrub-pole, fragmented forest, and intact forest treatments in a reclaimed mountaintop removal mine landscape in southern West Virginia, 2000-2002.

Table 6. Mean and standard error (SE) for habitat variables measured at grassland $(n=3)$, shrub-pole $(n=3)$, fragmented forest $(n=3)$, and intact forest $(n=3)$ treatments in a reclaimed mountaintop removal mine landscape in southern West Virginia, 2002.. Dashed lines indicate treatments where variables were not measured. Within a row, means with the same letters are not different at á $=0.10$ (Waller Duncan K-ratio t-test)

Table 7. Herpetofaunal species richness and relative abundance (adjusted per 100 array nights and per trap effort) from drift fence arrays in on- and off-mine treatments in a reclaimed mountaintop removal mine landscape in southern West Virginia, 2002. Within a row, means with the same letters are not different at á $=0.10$ (Waller Duncan K-ratio t-test).

Table 8. Number of individuals and species of herpetofaunal groups captured in drift fence arrays in onand off-mine treatments in southern West Virginia, 2002.

Table 9. Number of individuals $(\mathrm{N})$ of herpetofaunal species captured in drift fence arrays and percent of drift fence arrays $(\%)$ at which a species was captured in on-mine $(n=6)$ and off-mine $(n=6)$ treatments on and near mountaintop removal mines in southern West Virginia, 2002.

Table 10. Mean and standard error (SE) for habitat variables measured at on-mine $(n=6)$ and off-mine $(n=6)$ treatments in grassland and shrub-pole habitats in a reclaimed mountaintop removal mine landscape in southern West Virginia, 2002. Dashed lines indicate variables that had insufficient data to conduct statistical analyses or that had a significant interaction between treatment and habitat. Statistical results are from comparison of on- and off-mine treatments (grassland and shrub-pole habitats combined). 


\section{CHAPTER 3:}

Table 1. Habitat characteristics at reference streams $(\mathrm{N}=3)$ and valley fill streams $(\mathrm{N}=4)$ by stream order in a reclaimed mountaintop removal mine landscape in southern West Virginia, 2001. Habitat characteristics based on Amphibian Monitoring Program protocol (Jung et al. 1999): BA = bank (river edge, soil, lacks rocks); $\mathrm{RU}=$ run (smooth current); $\mathrm{BL}=$ boulder $(>1.5 \mathrm{~m}$ in diameter); $\mathrm{RA}=$ rapid (fast current broken by obstructions); $\mathrm{LR}=$ large rocks (0.5-1.5 $\mathrm{m}$ in diameter); $\mathrm{PO}=$ pool (standing water); $\mathrm{SR}=$ small rocks (0.1-0.5 $\mathrm{m}$ in diameter); $\mathrm{CA}=$ cascade (water flowing over slanting rocks); $\mathrm{RG}=$ rubble / gravel $(<0.1 \mathrm{~m}$ in diameter); RI = riffle (ripples and waves); WD = woody debris; DR = dry (no visible moisture or water).

Table 2. Number of $10 \mathrm{~m} \times 2 \mathrm{~m}$ transects in each treatment surveyed for stream salamanders in a reclaimed mountaintop removal mine landscape in Southern West Virginia, June-November, 2002.

Table 3. Description of habitat variables measured at each $10 \mathrm{~m}$ x $2 \mathrm{~m}$ stream transect, 2002. All definitions are verbatim from Jung (2002), with the exception of those marked with an asterisk. I created and defined habitat variables marked with an asterisk.

Table 4. Number of individuals and species of herpetofaunal groups captured in stream surveys in one intermittent reference stream (3 35-m stream segments sampled), two first-order reference streams (7 35-m stream segments sampled), one second-order reference stream (5 35-m stream segments sampled), and four second-order valley fill streams (17 35-m stream segments sampled), on reclaimed mountaintop removal mine areas in southern West Virginia, May-October, 2001.

Table 5. Number of individuals and species captured $(\mathrm{N})$ and percent of total captures and of total species captured in stream surveys in valley fill streams and reference streams on and near reclaimed mountaintop removal mines in southern West Virginia, May-October, 2001.

Table 6. Mean and standard error (SE) of stream salamanders per 35-m segment of valley fill and reference streams on and near reclaimed mountaintop removal mines in southwestern West Virginia, May-October 2001.

Table 7. Number of captures per stream salamander species and age class $(A=$ adult, $\mathrm{L}=$ larvae $)$ in each treatment surveyed for stream salamanders in a reclaimed mountaintop removal mine landscape in southern West Virginia, June-November, 2002. DEFU = Northern Dusky Salamander (Desmognathus fuscus); DEMO = Seal Salamander (D. monticola); DESP = Desmognathus spp.; EUCI - Southern Two-lined Salamander (Eurycea cirrigera); GYPO = Spring Salamander (Gyrinophilus porphyriticus); PSRU = Northern Red Salamander (Pseudotriton ruber); UNK = Unknown spp.

Table 8. Mean, standard error (SE), and range of relative abundance of stream salamanders (individuals $/ \mathrm{m}^{2}$ ) captured in reference streams and valley fill streams in a reclaimed mountaintop removal mine landscape in southern West Virginia, July to November, 2002. There was a significant interaction between treatment and season in 2nd order reaches for adult salamanders and adult Desmognathus spp., so I analyzed seasons separately.

Table 9. Mean, standard error (SE), and range of habitat variables measured in reference and valley fill streams in a reclaimed mountaintop removal mine landscape in southern West Virginia, June to November, 2002. O = overall ( 1 st order and 2 nd order reaches combined), $1=1$ st order stream reaches, $2=2$ nd order stream reaches. I did not compute statistics for variables with $0 \%$ cover in both treatments or for variables with sample sizes too small for statistical analyses.

Table 10. Correlations between salamander groupings and habitat variables in valley fill and reference streams in a reclaimed mountaintop mine landscape in southern West Virginia, 2002. Significant at $\mathrm{P}=0.0053$ (Bonferroni adjustment). 


\section{CHAPTER 4:}

Table 1. Number of salamanders captured $(\mathrm{N})$ per species, proportion that each species contributed to total captures, and number of mines and transects where each species was captured in a reclaimed mountaintop removal mine landscape in southern West Virginia, 2001-2002.

Table 2. Number of salamanders captured at 25-m increments along 200-m transects that spanned from 0-m at edges (E) to 100-m into reclaimed (R) (grassland: GR) and shrub-pole: S-P) and forested (F) habitats .

Table 3. Terrestrial salamanders (obligate terrestrial only) captured at 25-m increments along 200-m transects that spanned from $0-\mathrm{m}$ at edges $(\mathrm{E})$ and $100-\mathrm{m}$ into both reclaimed mountaintop removal mine habitats (R) and forested habitat (F) in southern West Virginia, 2001-2002.

Table 4. All salamanders (includes obligate terrestrial) captured at 25-m increments along 200-m transects that spanned from $0-\mathrm{m}$ at edges $(\mathrm{E})$ and $100-\mathrm{m}$ into both reclaimed mountaintop removal mine habitats $(\mathrm{R})$ and forested habitat (F) in southern West Virginia, 2001-2002.

Table 5. Terrestrial salamander (obligate terrestrial only) and all salamander (includes obligate terrestrial salamanders) comparisons of relative abundance between coverboard sampling stations spaced every 25-m along transects spanning from mountaintop removal mine edges $(0 \mathrm{~m})$ of reclaimed grassland and reclaimed shrub-pole habitat into forested habitats $(100 \mathrm{~m})$ in southern West Virginia, 2001-2002.

Table 6. Terrestrial salamanders (obligate terrestrial only) and all salamanders (includes obligate terrestrial) captured along a $200-\mathrm{m}$ transect traversing reclaimed grassland and reclaimed shrub-pole habitats (-) and forested habitats (+) in southern West Virginia, 2001-2002; edge is denoted by 0.

Table 7. Relative abundance of terrestrial salamander (obligate terrestrial only) and all salamander (includes obligate terrestrial) captures among treatments in a reclaimed mountaintop removal mine landscape in southern West Virginia, 2001-2002. Within a column, means with the same letter do not differ (alpha=0.10). 


\section{LIST OF FIGURES}

\section{CHAPTER 1:}

Figure 1. Location of mountaintop removal mine sites within watersheds in southern West Virginia.

Figure 2. Aerial photograph of Hobet 21 mountaintop removal mine with locations of sampling points in

Boone County, West Virginia.

Figure 3. Aerial photograph of Dal-Tex mountaintop removal mine with locations of sampling points in Logan County, West Virginia.

Figure 4. Aerial photograph of Cannelton mountaintop removal mine with locations of sampling points in Kanawha and Fayette counties, West Virginia

Figure 5. Aerial photograph of sampling points along Ash Fork (intact forest) in Nicholas County, West Virginia.

Figure 6. Aerial photograph of Fork Creek Wildlife Management Area and Camp Creek Road with locations of sampling points in Boone County, West Virginia

Figure 7. Aerial photograph of Mud River Wildlife Management Area with locations of sampling points in Lincoln County, West Virginia.

\section{CHAPTER 2:}

Figure 1. Placement of herpetofaunal drift fence array relative to road or stream. The central separation between drift fences was $15 \mathrm{~m}$; figure is not to scale.

Figure 2. Placement of vegetation sampling plots at the center of drift fence arrays and $35 \mathrm{~m}$ from the center at $0^{\circ}, 120^{\circ}$, and $240^{\circ}$.

Figure 3. Example of how a Robel pole is used to measure vegetative cover and grass height.

Figure 4. Sampling points on grassland vegetation subplot for vegetative cover and grass height measurements (Robel pole) and organic litter depth measurements.

\section{CHAPTER 3:}

Figure 1. Stream sampling design for reference streams (RS) and valley fill streams (VFS) in a reclaimed mountaintop mine landscape in southern West Virginia. Transect dimensions were $10 \mathrm{~m}$ x $2 \mathrm{~m}$ and were centered on riffles (RIF) and pools, 2002.

\section{CHAPTER 4:}

Figure 1. Placement of coverboard transects relative to reclaimed mine and forested treatments in a reclaimed mountaintop removal mine landscape in southern West Virginia, 2001-2002.

Figure 2. Terrestrial salamander captures (obligate terrestrial only) along a $200-\mathrm{m}$ transect traversing reclaimed mountaintop removal mine (-) and forested $(+)$ habitats in a reclaimed mountaintop removal mine landscape in southern West Virginia, 2001-2002; edge is denoted by $0 \mathrm{~m}$. 
Figure 3. All salamander (includes obligate terrestrial) captures along a 200-m transect traversing reclaimed mountaintop removal mine (-) and forested $(+)$ habitats in a reclaimed mountaintop removal mine landscape in southern West Virginia, 2001-2002; edge is denoted by $0 \mathrm{~m}$.

\section{LIST OF APPENDICES}

Appendix 1. Herpetofaunal species that may potentially occur (Exp=Expected; $x$ ) in grassland, shrub-pole, fragmented forest, and intact forest treatments (Behler and King 1995; Green and Pauley 1987; Conant and Collins 1998), compared to those actually observed (Obs) in drift fence arrays (a; 2000-2002), from incidental sightings (i; 2000-2002), during stream surveys (s; 2001-2002) and under coverboards (c; 2001-2002) in southern West Virginia in a reclaimed mountaintop removal mine landscape. Ranges of species were based

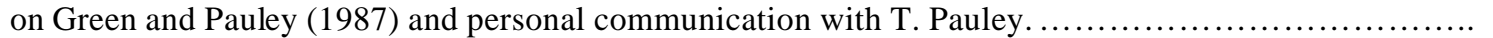




\section{CHAPTER 1}

\section{INTRODUCTION AND LITERATURE REVIEW}

Mountaintop Removal Mining Process

Mountaintop removal is defined as "a mining method in which the top of a mountain or ridge is flattened in the process of mining (Barnhisel et al., 2000)." With this large-scale surface mining technique, overburden above a coal seam is excavated and temporarily set aside (United States Environmental Protection Agency, 2000). Mountaintop removal mining is used in West Virginia, Virginia, Tennessee, Kentucky, and Pennsylvania in areas characterized by steep terrain and large contiguous coal reserves that lie close enough to the surface to be economically mineable (United States Environmental Protection Agency, 2000). Mountaintop mining is a more general term and can refer to contour mining, area mining, or mountaintop removal mining, which are three types of surface coal mining operations whereby excess spoil gets disposed into valleys (United States Environmental Protection Agency, 2000), but sometimes this term is used synonymously with mountaintop removal mining.

Overburden material becomes a mixture of topsoil and unconsolidated rock material upon its removal and subsequent replacement. Topsoil is not separately removed and then replaced on the surface of reclaimed mountaintop removal mines for a variety of reasons, one of which is cost (Daniels and Stewart, 2000). Because the geological strata become unconsolidated, they constitute a much greater volume than the once consolidated material (United States Environmental Protection Agency, 2000). Rock type also affects extent of swelling. For example, broken sandstone fills a greater space than fragmented shale (United States Environmental Protection Agency, 2000). Due to these contributing swell factors, not all overburden can be returned to the mountaintop; otherwise, long-term stability problems may stem from too steep of slopes (Sciulli et al., 1986; Bell et al., 1989; United States Environmental Protection Agency, 2000) and accelerated erosion (due to wind or water) (Brenner, 1985; Sciulli et al., 1986). Erosion increase may then impose difficulties in site revegetation (Brenner, 1985; Sciulli et al., 1986). Hauling excess spoil to other sites is also too costly (United States Environmental Protection Agency, 2000); therefore, it is deposited into valleys located within close proximity to the active minesites, creating a valley fill (Barnhisel et al., 2000; United States Environmental Protection Agency, 2000). 


\section{Valley Fills}

Head-of-hollow valley fills are positioned at the headwaters of watersheds (Daniels and Stewart, 2000). They are created by dump trucks unloading overburden into the valley from along the ridgeline. In this process, a natural segregation of large and small rocks occurs, with large, boulder-sized ones falling to the valley bottom and small rocks settling on top. This system to create valley fills, known by a variety of names such as Durable Rock Fill Method, Gravity Placement Method, or Kentucky Method, has been in use since 1980 (J. Skousen, Extension Specialist on Land Reclamation and Professor of Soil Science at West Virginia University). A more controlled method of spoil placement in valley heads is undesirable to coal operators because of difficulty in maneuvering equipment and complications in controlling grade (Toy and Black, 2000). In addition, the Kentucky method is more cost-efficient and less laborintensive than more controlled placement methods (Anonymous, 1980; Loeb, 1997).

Mountaintop removal mining disturbance encompasses a large area; therefore, reconstruction of landforms for complex head-of-the-hollow valley fills may require reclamation of first-, second-, third-, and higher-order drainage basins (Toy and Black, 2000). It is common for valley fills in the Appalachians to be hundreds of hectares in size (Daniels and Stewart, 2000) and to contain thousands of cubic meters of fill material (Plass, 2000); total valley fill coverage continually increases in West Virginia (United States Environmental Protection Agency, 2000).

Head-of-hollow valley fills are designed to control groundwater discharge, run-on, and runoff (Toy and Black, 2000). Riprap channels are positioned alongside valley fill terraces and in streams below the fill. They serve to divert surface waters around the fill and thus, reduce infiltration into the spoil (Sciulli et al., 1986; Daniels and Stewart, 2000). In addition, they function as drainage channels and erosion control structures (Sciulli et al., 1986; Plass, 2000).

Streams pose particular challenges in topographic reconstruction because channel design must consider flood-stage flows, groundwater discharge fluctuations, hillslope gradient, and other factors (Toy and Black, 2000). These considerations and others aforementioned (e.g., steep slopes) impose substantial limits on what techniques can be used to reclaim watersheds and have led to the design and use of head-of-hollow valley fills. Regulations established by the United States Bureau of Reclamation (1977) and the United States Environmental Protection Agency (1976) are adhered to when designing channels (Toy and Black, 2000). For example, discharge conditions must closely approximate the quality and quantity of pre-disturbance conditions (Toy 
and Black, 2000). Although completely accurate predictions are not possible, conservative estimates of average velocity, discharge, and flow stage are used when designing channels (Toy and Black, 2000).

Valley fill terraces are sufficiently compacted to ensure slope stability and reduce settlement; unstable slopes impose limits on land use and pose a hazard to people living downstream (Sciulli et al., 1986). Height between terraces, type of hillslope materials used, and hillslope gradient must all meet federal guidelines (e.g., vertical height between terraces rarely can exceed $12 \mathrm{~m}$; hillslope gradient must be 3-50\%) (Toy and Black, 2000). Valley fills and the surrounding mined area are then revegetated (Daniels and Stewart, 2000) according to the postmining land-use plan or reclamation objectives (Richards et al., 1993; Skousen and Zipper, 1996).

\section{Vegetation / Soil}

Species planted to revegetate a site must be tolerant of geologic materials, soil, and moisture conditions at the site (Richards et al., 1993; Brenner, 2000; Toy and Black, 2000) or the substrate must be treated so that it becomes suitable for plant growth (Richards et al., 1993). Stressful conditions on reclaimed coal surface mines that hinder plant establishment and growth include extreme soil pH (Richards et al., 1993; Slick and Curtis, 1985), erosion, excessively high surface and soil temperatures, limiting moisture (Slick and Curtis, 1985), lack of nutrients and organic matter (Richards et al., 1993; Norland, 2000), toxicity, and compaction (Richards et al., 1993). Compacted soils have soil pore spaces of insufficient size to retain water and may be impenetrable for plant roots, producing minesoils inhospitable to plant growth (Richards et al., 1993). Placement of fertilizers, lime, and mulches on the soil surface serve to ameliorate these conditions and make minesoils more suitable for plant growth (Norland, 2000). Pioneer species provide several improvements to site conditions, including organic matter, soil structure, and nitrogen (Richards et al., 1993).

Until recently, mountaintop removal mining operators were not required to return the land to approximate original contour (AOC) as required by the Surface Mining Control and Reclamation Act (Public Law 95-87, 1977), provided that a variance was obtained. A variance could be acquired if suitable post-mining land was developed, such as wildlife habitat, grazing pastures, or commercial development. In large part due to this variance, valley fills have increased in size and number in West Virginia, Kentucky, and Virginia (United States 
Environmental Protection Agency, 2000). Such post-mining land uses are no longer permitted with variances from AOC. Effective June 25, 2002, the West Virginia Surface Mining Reclamation Rule (38CSR2) limits post-mining land use to forestry or commercial forestry if an AOC variance is granted.

Geology

Acid mine drainage (AMD) is a common circumstance resulting from mining. However, in southern West Virginia, AMD is not a condition typically associated with mountaintop removal mining (J. Skousen, Extension Specialist on Land Reclamation and Professor of Soil Science at West Virginia University). Minimizing or eliminating AMD is achievable because the coalfields of southern West Virginia have low sulphur content ( $1 \% \mathrm{~S})$, compared to coal from the northern part of the state, which can be up to $6 \%$ sulphur (Gerena, 2001). In the southern coalfields, pyrite exists in small, isolated pockets within only a few coal seams (J. Skousen, Extension Specialist on Land Reclamation and Professor of Soil Science at West Virginia University). Thus, with proper overburden handling and placement, pyrite can be isolated and kept from water and air so that it does not become oxidized and produce acidic soil and water conditions. This is not to say that acid mine drainage is never produced from mountaintop removal operations; however, its occurrence is much less frequent than in areas containing high pyrite (e.g., central and eastern Pennsylvania and northeastern West Virginia).

\section{History of Mountaintop Removal Mining}

In West Virginia, mountaintop removal mining began on a small scale in the late 1960s. Several factors have contributed to its increase in popularity. First, coal in southern West Virginia has a high heat value, meaning that less coal has to be burned to provide the same amount of heat as compared to coal low in heat value. Second, amendments to the Clean Air Act in 1990 called for reductions in sulfur dioxide and nitrogen dioxide, increasing the value of and the demand for low-sulphur coal (Loeb, 1997; Gerena, 2001). Third, the advent of the dragline permits $100 \%$ extraction of the resource at a fast rate and makes it economically feasible to mine thin seams of coal. Fourth, in recent years, there has been an unprecedented increase in demand for electricity in the United States, and with this demand, comes a corresponding increase in need for coal (Loeb, 1997; Gerena, 2001), as over 50\% of electricity in this country is provided by coal (Watson, 1996). 
Although mountaintop removal mining has been implemented for over 30 years in West Virginia, the separate and synergistic effects of such large-scale disruption to soil, geologic, and hydrologic regimes have only recently come under investigation. In 1998, former West Virginia Governor Cecil Underwood formed a task force to study the effects of mountaintop removal mining on the economy, environment, and people of the state (United States Environmental Protection Agency, 2000). The Task Force recommended establishment of a state office to regulate effects of this mining method on people of the state and establishment of a nationwide stream mitigation policy. Further, they suggested the creation of commercial forestland and the abolishment of fish and wildlife habitat as postmining land uses. They also thought that further investigations into mountaintop removal mining and its effects should be conducted.

Also in 1998, an interagency group composed of the Office of Surface Mining (OSM), the United States Environmental Protection Agency (EPA), the United States Army Corps of Engineers (COE), and the United States Fish and Wildlife Service (FWS) was formed (United States Environmental Protection Agency, 2000). This group, the Federal Regulatory Operations Group (FROG), was established to address concerns about mountaintop mining operations and to examine factors associated with these operations, such as stream impacts, fill stability, efficacy of mining programs, and various other concerns, such as aquatic, terrestrial, and community issues. Recently, the mountaintop removal mining technique was litigated, in part due to suspected adverse impacts on fish, wildlife, and the general environment (Vollers, 1999) and EPA is currently conducting an environmental impact assessment of this mining technique, the draft of which was released for public comment on May 29, 2003.

\section{$\underline{\text { Environmental Effects }}$}

Disruption of terrestrial and aquatic habitats caused by mountaintop removal mining may involve a permanent alteration in topography and possibly will affect entire hydrologic systems (Starnes and Gasper, 1995). Terrestrial and aquatic impacts include direct loss or fragmentation of habitat, as well as alterations in habitat structure and water and soil chemistry. Streams may never return to their original condition due to profound changes in geomorphology spurred by mining (Research Environmental and Industrial Consultants, Inc., 2000). Soils

The excavation process involved with mountaintop removal mining results in a considerable loss of native soils (J. Skousen, Extension Specialist on Land Reclamation and 
Professor of Soil Science at West Virginia University). Minesoils are weakly to moderately structured (Sencindiver and Ammons, 2000). They often lack organic matter (Richards et al., 1993; Norland, 2000) - material that improves soil structure and water-holding capacity of soils (Richards et al., 1993). Reclaimed mine surfaces frequently contain parent materials or other materials that have been subjected to little or no weathering (Sencindiver and Ammons, 2000). In addition, they often are low in nutrients, and stay as such until significant time has passed for aging processes to occur.

The rate at which soil development occurs depends on the mining and reclamation methods used (Sencindiver and Ammons, 2000). Other factors that influence minesoil properties and soil horizon development include natural processes such as freeze-thaw and shrink-swell cycles, dissolution, leaching, oxidation, organic matter decomposition and incorporation, and aggregation of soil particles into peds (Daniels and Amos, 1981; Roberts et al., 1988a). Because high mineral content and low organic matter characterize mountaintop removal minesoils (Powell, 2000b), the land is essentially set back to primary succession. Five years may pass since time of initial disturbance before thin A horizons form on them (Haering et al., 1993; Roberts et al., 1988a,b; Thomas and Jansen, 1985), but Thomas et al. (2000) found that some seven-year-old minesoils had deeper A horizons than nearby native soils on one mountaintop removal mine in southern West Virginia. It is not possible for reclamation to replicate all geologic material and soil properties; it can only serve to simulate processes that take hundreds or thousands of years to occur (Toy and Black, 2000).

\section{Vegetation}

Grass-legume mixtures used on reclaimed mines often include Kentucky-31 fescue (Festuca arundinacea), crown vetch (Coronilla vaira), birdsfoot trefoil (Lotus corniculatus) and lespedeza (Lespedeza spp.). While useful for soil stabilization and erosion control, these same species may restrict or exclude establishment of native flora (Brenner and Goughler, 1983) and are often not conducive to wildlife habitat development, nor are they favored food species for wildlife (Brenner, 2000). Furthermore, other tall shrub species frequently planted during reclamation, such as autumn olive (Eleaganus umbellata), are useful as producers of soft mast, but quickly proliferate and effectively inhibit growth and establishment of native species that are more beneficial to wildlife species (Brenner, 2000). Surface mining can lead to increases in pioneer species coverage and declines in late successional species (Wolf, 1994). Despite these 
criticisms, many other vegetation species are not likely to survive on reclaimed mines. Planting options are limited to tolerant species or to species that can rapidly colonize a site and provide essential stability, at least until suitable soil conditions return (Powell, 2000b), which may mean selection of species that are not valuable to wildlife species as food or cover or that are not native to the area.

\section{Streams}

Destruction of first-, second-, third-, and higher-order drainage basins by cover of valley fill material or alteration of stream conditions may considerably impact areas downstream in the watershed (United States Environmental Protection Agency, 2000). Headwaters in particular are ecologically unique portions of streams. They moderate downstream flow rate, function as areas of nutrient transformation, harbor organic materials and nutrients (Wallace, 2000a), and serve as the site where important energy sources enter into lotic systems (United States Environmental Protection Agency, 2000; Wallace, 2000b). Removal of headwater habitats and higher order reaches may affect energy availability further downstream (United States Environmental Protection Agency, 2000) and disrupt other important biological functions. Additionally, aquatic biota in headwaters perform many valuable functions, such as aiding nutrient uptake and transformation (Wallace, 2000a). Headwaters also tend to be cooler in the summer and warmer in the winter compared to areas downstream (Wallace, 2000a), which may serve as a reprieve for aquatic biota from temperature extremes of either season. Construction of head-of-hollow valley fills may alter these characteristic temperatures. For example, waters exiting valley fill toes often maintain the same temperatures year-round (Wallace, 2000b).

Even though conservative estimates of average velocity, discharge and flow stage are used when designing stream channels (Toy and Black, 2000), stream functions and structures lost due to direct and indirect effects of valley fill construction have yet to be completely restored through stream reconstruction (Powell, 2000b). Reconstructed streams seldom reflect the habitat diversity present prior to mining (Brenner, 2000). Proper stream restoration should strive to reproduce the pre-mining morphology and flow patterns (Brenner, 2000). The difficulty involved in intercepting an adequate supply of groundwater to maintain a base flow (Powell, 2000a) is a major factor limiting this reproduction and full restoration of stream functions. Although reconstructed channels may adequately manage storm flows, Powell (2000a) asserted that without base flow, habitation by lotic biota in first- and second-order streams is improbable. 
Improving design of constructed wetlands that serve to mitigate loss of streams on reclaimed mountaintop removal mine sites may ameliorate some of these negative effects by boosting groundwater recharge (Wallace, 2000b).

\section{Herpetofauna}

Mountain headwaters are home to many plethodontid salamander species in the eastern United States (Bishop, 1967). Forested headwater streams comprise 60-75\% of total stream length and watershed area in Mid-Atlantic States (Jung et al., 2000). In headwaters, salamanders are often the dominant or most abundant vertebrate predators or the predators that contribute the most biomass (Burton and Likens, 1975; Hall et al., 1978; Murphy and Hall, 1981; Hairston, 1987), especially where predatory fish are absent (Burton and Likens, 1975; Krzysik, 1979; Hawkins et al., 1983). Amphibian monitoring programs use stream salamanders as potential indicators of headwater stream quality (Ohio Environmental Protection Agency, 2002) and densities of stream amphibians in general have been used as indicators of ecosystem stress (Welsh Jr. and Ollivier, 1998; Lowe and Bolger, 2002). In general, however, there is a paucity of ecological research conducted on stream amphibians in the northeastern region of the United States, according to Lowe and Bolger (2002).

Stream plethodontids typically exhibit stable population sizes and age structures and high densities (Hairston, 1987; Burton and Likens, 1975; Welsh Jr. and Ollivier, 1998; Jung et al., 2000, Rocco and Brooks, 2000). These traits, together with their porous skin that quickly reacts to changes in terrestrial and aquatic environmental quality (Jones, 1986; Blaustein and Wake, 1990; Shaffer, 1991) and their philopatry (Welsh Jr. and Lind, 1992), make them ideal for use as bioindicators (Kucken et al., 1994; Welsh Jr. and Ollivier, 1998). The long lives of amphibians make them even more desirable for use as bioindicators over the more traditionally used animals - fish and invertebrates (Welsh Jr. and Ollivier, 1998); some salamanders can live up to 55 years (Hairston, 1987). Furthermore, stream salamanders, due to their physiological constraints and anatomical characteristics, are limited in mobility (Green and Pauley, 1987), making them more reliable as bioindicators than species that exhibit seasonal movements (Welsh Jr. and Ollivier, 1998). These restrictions, coupled with their small home ranges, suggest that local abundances of stream salamanders should reflect impacts of disturbance (Corn and Bury, 1989).

Amphibian populations can aid in assessment of both terrestrial and aquatic environmental quality (Jones, 1986; Blaustein and Wake, 1990; Shaffer, 1991). Many of the 
reasons used to illustrate the ecological importance of stream salamanders generally apply to most amphibians (e.g., long-lived). Plethodontid salamanders are the most abundant forest salamanders (Burton and Likens, 1975) and have high densities (up to ten animals $/ \mathrm{m}^{2}$ ) (Gergits and Jaeger, 1990); thus, significant reductions in their abundance could have far-reaching effects on forest ecosystems (Pough et al., 1987; Welsh Jr. and Lind, 1988). The survival of woodland salamanders is dependent on soil habitability; only 2-32\% of salamander populations can be found on the surface and in leaf litter while the rest are found throughout the soil (Taub, 1961). Therefore, large-scale soil disruption sustained from mountaintop removal mining may significantly impact these salamanders.

Reptiles are relatively resistant to environmental stresses that would adversely affect amphibians (e.g., droughts) and they maintain fairly high population numbers (Read, 1992). Therefore, they are better as indicators of non-climatic environmental changes (Read, 1992) and provide a unique compliment to amphibians as study organisms.

Herpetofauna have both consumptive and nonconsumptive economic value to humans (Jones, 1986) such as tools for teaching and research (Stebbins and Cohen, 1995). Amphibian study also has contributed to advancements in medicine (Stebbins and Cohen, 1995; Pough et al., 2001) and in some countries, herpetofauna have important cultural meaning (Pough et al., 2001). Despite all of these interesting and valuable characteristics of herpetofauna, their significance in the environment is often ignored (Taub, 1961; Bury, 1983).

\section{Past Research on Impacts of Mining and Related Effects on Herpetofauna}

Impacts on herpetofauna of coal mining methods other than mountaintop mining have been documented (Riley, 1952, 1960; Myers and Klimstra, 1963; Redmond, 1980; Turner and Fowler, 1981; Gore, 1983; Fowler et al. 1985, Middelkoop et al., 1998), as have the impacts of mining for other materials (e.g., metals, phosphate) (Porter and Hakanson, 1976; Schnoes and Humphrey, 1987; Saugey et al., 1988; Twigg and Fox, 1991). None of these studies focused on mountaintop removal mines and none were conducted in West Virginia. In addition, most of these studies focused only on amphibians. Some authors did not use standardized survey methods, did not analyze their results statistically, and / or conducted their work prior to the enactment of the Surface Mining Control and Reclamation Act of 1977 (SMCRA; Public Law 95-87, 1977). The SMCRA standardized coal mining and reclamation for the nation and imposed regulations on surface impacts of mining and water quality standards (Starnes and 
Gasper, 1995). Only one study (Hamilton 2002) has examined effects of mountaintop removal mining on herpetofauna.

Hamilton (2002) compared mountaintop removal mining valley fill streams (reclaimed 6, 16, and 19 years prior to her publication date) with reference streams in southern West Virginia to determine impacts on streamside salamander communities. She found a lower relative abundance of salamanders in two of three valley fill streams when compared to two reference streams. However, with increasing time since valley fill construction, streamside salamanders in the third valley fill stream appeared to reach abundance levels similar to that of reference streams. Because one of the two reference streams chosen for study by Hamilton (2002) had been impacted by surface mining approximately 50 years prior to her study, the mining activity may have impacted the stream salamander community in such a way that relative abundance during the time of her study may not have been characteristic of what was present prior to disturbance.

\section{Water Quality}

Several researchers have completed studies on water quality of streams impacted by mountaintop removal mining (United States Environmental Protection Agency, 2000; Bryant et al., 2002; Hedrick and Ras, 2002; Hartman et al., unpubl. data); results by Hedrick and Ras (2002) were not analyzed statistically. Three of these studies found elevated levels of specific conductance in valley fill streams (Bryant et al., 2002; Hedrick and Ras, 2002; Hartman et al., unpubl. data) and two discovered high levels of sulfate, hardness, and total dissolved solids in fill streams (Hedrick and Ras, 2002; Bryant et al., 2002). Meanwhile, both Hartman et al. (unpubl. data) and Bryant et al. (2002) reported high concentrations of calcium, magnesium, manganese, and potassium. Levels of chloride (Hedrick and Ras, 2002), sodium, copper, nickel, and iron (Hartman et al., unpubl. data), as well as selenium and nitrate / nitrite concentrations and acidity (Bryant et al., 2002) were also all found to be high in valley fill streams. Benthic macroinvertebrate taxa richness decreased below valley fills, as did EPT (Ephemeroptera, Plecoptera, Trichoptera) Index and percent EPT individuals (Hedrick and Ras, 2002). Furthermore, lower densities of Ephemeroptera, Coleoptera, Odonata, scrapers, shredders, and non-insect invertebrates occurred in valley fill streams and many macroinvertebrate parameters (e.g., Ephemeroptera density, EPT density, Plecoptera density) were negatively related to heavy metals (Hartman et al., unpubl. data). 
The United States Environmental Protection Agency (2000) documented other changes in water quality due to mountaintop removal mining. Prior to mining, groundwater flowed primarily through clean fracture zones (United States Environmental Protection Agency, 2000). After mining, it most often flowed through pore spaces of spoil material (United States Environmental Protection Agency, 2000) creating pseudokarst hydrology, in which water moves throughout the large pores of discontinuous, unconsolidated material of mine backfills with no respect to gravity (J. Skousen, Extension Specialist on Land Reclamation and Professor of Soil Science at West Virginia University). This change in flow pattern may influence chemical and physical properties of receiving surface waters. One change in physical properties may include an increase in sedimentation.

Waters (1995) reported that, "surface mining has been labeled the greatest potential source of sediment generation among all forms of mining." Abandoned coal mine spoils are currently the leading contributors of sediment (Waters, 1995). Sedimentation is a common stressor to lotic ecosystems (Waters, 1995) and Toy and Black (2000) labeled sediment the "single largest source of surface-water contamination."

Sedimentation increases in severity when single watersheds contain multiple mines (Starnes, 1985). Running extensive mountaintop mining operations may have effects similar to running multiple small mines within a watershed. The steep slopes of the Appalachian coal region, where mountaintop removal mining is most common, generate the largest amount of sediment (Starnes, 1985). Mining activities often produce sediment that fills and coats stream substrate (Nelson et al., 1991).

\section{Water Chemistry}

When examining effects of water chemistry on amphibians, relationships are complex. The following factors all contribute to the type and magnitude of effect on amphibians: 1) presence and concentration of other cations, metals, or compounds (Freda, 1986; Horne and Dunson, 1995), 2) influence of other abiotic factors (e.g., temperature, ultraviolet radiation) (Freda and Dunson, 1986; Horne and Dunson, 1995; Long et al., 1995), 3) the species of amphibian(s) being studied (Horne and Dunson, 1995), 4) age class of the amphibian(s) (Freda, 1986), 5) frequency and duration of exposure (Freda and Dunson, 1984), 6) size, depth, and type

of water body, 7) opportunity for amphibians to escape to alternate, more suitable habitats, and 
8) genetic variation (Pierce and Wooten, 1992). Not only is there among-species variation to these factors, considerable within-species variation also occurs (see review by Pierce, 1993).

Most studies on the relation of water chemistry to amphibian diversity and abundance focused on anurans (e.g., Dunson and Connell, 1982; Freda and Dunson, 1984; Freda and Dunson, 1985a; Freda and Dunson, 1986; Dale et al., 1985; Clark, 1986; Beattie and TylerJones, 1992; Freda and Taylor, 1992; Long et al., 1995) and / or amphibian species of temporary pond habitats (e.g., Pough, 1976; Freda and Dunson, 1984; Dale et al. 1985; Freda and Dunson, 1985a; Freda and Dunson, 1985b; Freda and Dunson, 1986; Albers and Prouty, 1987; Rowe et al., 1992; Sadinski and Dunson, 1992); relatively few investigators have examined effects on plethodontid salamanders that reside in headwater streams, seeps, and springs (Huckabee et al., 1975; Redmond, 1980; Mathews and Morgan, 1982; Gore, 1983; Roudebush, 1988; Kucken et al., 1994). Additionally, many of these studies documented impacts of low $\mathrm{pH}$ on herpetofauna, a condition not usually found in streams affected by mountaintop removal mining, as mentioned previously. However, one researcher who looked at substrate preference by salamander species found that of 8 salamander species studied, 5 species (including Northern Dusky Salamanders [Desmognathus fuscus]) demonstrated a preference for substrates of alkaline $\mathrm{pH}$ (7.7) over acidic substrates $(\mathrm{pH}=5.5)$ (Mushinsky, 1975). The other 3 species showed no substrate preference.

Albers and Prouty (1987) found a positive correlation between magnesium concentration and Spotted Salamander (Ambystoma maculatum) egg mass abundance, while an increase in aluminum was negatively related to embryonic survival. Freda and Dunson (1985b) found that addition of sodium, calcium, and magnesium into acidic water $(\mathrm{pH}=4.5)$ increased survivability for embryos of Spotted Salamanders and Jefferson Salamanders (A. jeffersonianum), but had the reverse effect on Wood Frog (Rana sylvatica) embryos. However, further increasing concentration of sodium, calcium, and magnesium into acidic water caused Spotted Salamander and Jefferson Salamander embryos to curl up and fail to hatch. While these generalizations can be made, there were complex associations between $\mathrm{pH}$ level, species, and individual ion concentrations, each of which produced unique results.

When Freda and Dunson (1984) experimented with tadpoles of Northern Leopard Frogs (Rana pipiens), they found that an increase in calcium ion concentration in waters of low $\mathrm{pH}$ increased tadpole survivability. Calcium acted to slow the efflux of sodium from tadpoles and increased survivability by a factor of four. In another study by Freda and Dunson (1986), 
variable hatching success of amphibians at various pond $\mathrm{pHs}$ was suspected to be a result of interactions between $\mathrm{pH}$ and other chemical variables, such as sodium, potassium, magnesium, calcium, aluminum, and chloride concentrations.

A suite of water chemistry variables in ditch, bog, marsh, pond, and lake sites in Nova Scotia were measured (Dale et al., 1985). The authors concluded that presence of adults, eggs, and larvae of 11 amphibian species could not be predicted by any of the parameters measured, which included $\mathrm{pH}$, alkalinity, conductivity, sodium, potassium, magnesium, calcium, sulfate, and chloride.

Clark (1986) established a correlation between decline in densities of American Bullfrogs (Rana catesbeiana), Spring Peepers (Pseudacris crucifer), and small Green Frogs (R. clamitans) with decreasing pond alkalinity. In constrast, Wood Frogs in her study frequented acidic, low alkalinity ponds.

Horne and Dunson (1995) examined interactive effects of $\mathrm{pH}$, metals, and dissolved oxygen content (DOC) by using a fully factorial statistical design with two levels of $\mathrm{pH}$, metals, and DOC. High metal concentrations in conjunction with low $\mathrm{pH}$ negatively impacted survivability of Jefferson Salamanders and Spotted Salamanders.

Acid mine drainage waters with a $\mathrm{pH}$ of 2.79 were toxic to embryonic and larval Boreal Toads (Bufo boreas) (Porter and Hakanson, 1976). This drainage was lethal to amphibian embryonic and larval stages even when diluted to $25 \%$ concentration using distilled water. With this diluted concentration, all zygotes and larvae died within 12 hours of exposure.

Stream waters of low $\mathrm{pH}$ and high sulfate, aluminum, and manganese concentrations resulted in death of the majority of larval Shovel nosed Salamanders (Leurognathus marmoratus) in an investigation done by Huckabee et al. (1975), while high conductivity and low pH in streams limited distribution of Desmognathine larvae in a study that Gore (1983) conducted. Redmond (1980) found that heavy metal concentrations in streams impacted by coal mining prohibited occupation by Black Mountain Dusky Salamanders (Desmognathus welteri) (Redmond, 1980). In addition, Kucken et al. (1994) found that streams acidified and contaminated with metals adversely affected salamander species with aquatic larval stages; abundance of Black-bellied Salamanders (D. quadramaculatus), Blue Ridge Two-lined Salamanders (Eurycea wilderae), Allegheny Mountain Dusky Salamanders (D. ochrophaeus), and Imitator Salamanders (D. imitator) were reduced in impacted streams. 
While valley fill streams have high metal and cation concentrations, they also contain high $\mathrm{pH}$ and high alkalinity, which are conditions entirely different from those described in any of the aforementioned studies. More work on impacts of alkaline mine drainage on stream salamanders is greatly needed.

\section{Habitat Structure}

In streams impacted by coal mine operations, Redmond (1980) observed an absence of Black Mountain Dusky Salamanders and Middelkoop et al. (1998) noted a reduction of Northern Dusky Salamanders. Redmond (1980) attributed these negative impacts in part to elevated silt and sand concentrations. Hawkins et al. (1983) found salamanders only in reaches with high gradients and low percent cover of sand. Several studies documented inverse relationships between stream salamander abundance and fine sediment accumulation (Corn and Bury, 1989; Welsh Jr. and Ollivier, 1998; Lowe and Bolger, 2002). Seal Salamanders (Desmognathus monticola) were intolerant of silt and sand and thus, shifted their habitat use from deeper stream waters to streambanks (Krzysik, 1979).

Increase of silt and sand can contribute to a reduction in species richness, frequency of occurrence, and biomass for stream salamanders (Corn and Bury, 1989) and may lessen their chances for reproductive success if sediment covers their eggs (Bruce, 1978). Filling of interstitial spaces between rocks by sand and sediment reduces available habitat for adult and larval salamanders ( Murphy and Hall, 1981; Hawkins et al., 1983; Corn and Bury, 1989; Lowe and Bolger, 2002). This diminished habitat accessibility for salamanders may subsequently lead to an increase in risk of exposure to predators (Lowe and Bolger, 2002). Sediment filling of substrate crevices may have long-lasting effects on stream salamander populations, particularly in low-gradient streams where sediment will likely remain sedentary (Hall et al., 1978; Corn and Bury, 1989).

Further documentation of the importance of substrate to stream salamanders is demonstrated by their preferred use of larger-sized substrate. Several stream salamander species were found most often under cobble-sized rocks (Corn and Bury, 1989; Welsh Jr. and Ollivier, 1998), but Black Mountain Dusky Salamanders showed a more general preference for large rock, gravel, or bedrock (Redmond, 1980). Higher relative amounts of gravel and cobble were the best predictors of Pacific Giant Salamander (Dicamptodon tenebrosus) abundance in streams studied by Welsh Jr. and Ollivier (1998). Mitchell (1999) found the majority of adult and larval 
Northern Spring Salamanders (Gyrinophilus porphyriticus) under rocks in flowing water and Welsh Jr. and Lind (1992) often found adult and larval Southern Torrent Salamanders (Rhyacotriton variegatus) in coarse substrates of streams. Davic and Orr (1987) observed a positive relationship between rock density and larval, juvenile, and adult salamander population densities in a mountain stream in North Carolina.

Boulders are also important rocks for streamside salamanders. In the absence of debris, boulders provide pool habitat in high gradient streams (Murphy and Hall, 1981). Relationships between rocks and mesohabitat types also appear to be important for salamander distribution and survivorship. Larvae of Streamside Salamanders (Ambystoma barbouri) are often abundant in fishless pools (Sih et al., 1992), whereas Welsh Jr. and Ollivier (1998) found Southern Torrent Salamanders to be absent from pools. In pools with fish, rocks may serve to increase the survivability of larvae until transformation (Petranka, 1998). Larval inhabitants of pools may have increased survivorship over those in riffles because during seasonal drying, pools may retain water while riffles may not (Holomuzki, 1991).

Large coarse woody debris (CWD) functions similar to boulders. It can create pool areas (Murphy and Hall, 1981), especially in low gradient streams with little to no cover by boulders. In small, high gradient streams, CWD serves to shape stream morphology and retain sediment (Murphy and Hall, 1981).

Degree of slope (i.e., gradient) can have significant effects on stream salamander presence, biomass, and populations (Hall et al., 1978; Hawkins et al., 1983; Corn and Bury, 1989). A low gradient in streams can exacerbate problems of sedimentation, as fine particles tend to remain stationary (Hall et al., 1978; Hawkins et al., 1983; Corn and Bury, 1989). When comparing high gradient streams, Murphy and Hall (1981) observed higher salamander biomass in clear-cut coniferous forests than in old-growth coniferous forests in Oregon, and found the opposite to be true for low gradient streams.

The above-reviewed studies make evident the significance of substrate and flow to stream salamanders. Valley fill construction directly and indirectly involves a loss of stream functions and structures (Powell, 2000b) and habitat diversity in reconstructed streams is often dissimilar to that before mining (Brenner, 2000). Stream salamander communities may bear considerable losses from this component of mountaintop removal mining. 
Burying stream headwaters and higher-order stream reaches with riprap may have a significant negative impact on streamside salamander communities in these streams and avian, mammalian, and herpetofaunal predators that feed upon them. For these reasons and those previously mentioned, the watersheds below valley fills and any impacts sustained by them and their biotic components deserve considerable attention.

Edge

Mature, mixed deciduous forest is the predominant land cover in West Virginia. Forests cover $78 \%$ of West Virginia, making this state the third most heavily forested in the country (Griffith and Widmann, 2003). Thus, reclaimed mine habitats supporting early successional scrub-shrub and grassland species contrast sharply with the surrounding natural landscape and create abrupt edges, which occur at the junction of two strongly dissimilar landscape elements where little to no gradation in vegetative structure and composition exists (Yahner, 1988). Increased exposure to wind, higher temperatures, and predation associated with open areas (Waldick, 1997) may impede dispersal and movement of salamanders. Forests tend to have cooler, moister, and more homogeneous climatic conditions than grasslands (Murcia, 1995) and therefore, the native forests should better meet habitat requirements of these salamanders, particularly salamanders from the family Plethodontidae. Salamanders in this family respire through their skin (Green and Pauley, 1987), which must remain moist and cool for efficient respiration (Feder, 1983).

Several researchers have documented impacts of edge on amphibia ns (Zimmerman and Rodriguez 1990, Culotta 1995, Marsh and Pearman 1997, Pearman, 1997), but few investigators conducted studies in temperate forests (DeGraaf and Yamasaki 1992, Perison et al. 1997, deMaynadier and Hunter Jr. 1998, Gibbs 1998a). In New Hampshire, DeGraaf and Yamasaki (1992) found that abundance of Eastern Red-backed Salamanders increased up to $65 \mathrm{~m}$ into mature forests, although these results were not analyzed statistically. Gibbs (1998a) found that forest edges strongly influenced capture rates of Red-spotted Newts (Notophthalmus $v$. viridescens); rates were higher in forest interiors than at forest-road edges or forest-residential edges. In South Carolina, Perison et al. (1997) found herpetofaunal diversity to be lower at edges than in clearcuts and reference forests and suspected this result to be due to high captures at edges of Southern Toads (Bufo terrestris), habitat generalists. In Maine, deMaynadier and Hunter Jr. (1998) found that abundance of 6 salamander species increased with increasing 
distance from clearcut edges and that abundance of 3 different amphibian groups (Eastern Redbacked Salamanders, 2 Ambystoma spp. and Wood Frogs) were affected 25-35 m into forests from clearcut edges. In temperate forests, no studies to date have supported the conclusions made by deMaynadier and Hunter Jr. (1998) regarding depth of edge effects on salamanders

Research on edges created by reclaimed mountaintop removal mining poses a unique contribution to edge effect studies because most land management practices that create edge are not of the size or disturbance magnitude as those created by mountaintop mining. On the three mountaintop removal mines used for my study, reclaimed mine habitat totaled approximately 2000 ha on each mine. In a report by Fedorko and Blake (1998) of the West Virginia Geological and Economic Survey (WVGES), they reported that in just three 7.5-minute quadrangles (Amherstdale, Myrtle, and Cowen) located in southern West Virginia, 2032 ha have been impacted by mountaintop removal mining and an additional 456 ha are covered by valley fills; each quadrangle spans approximately 15,300 ha. This area of disturbance represents roughly $5 \%$ of the total area among the three quadrangles.

\section{Clearcutting}

A land disturbance somewhat similar to mountaintop removal mining is clearcutting, which involves the removal of almost all vegetation in a given area to create new growing space. Serious detrimental effects on amphibian populations due to clearcutting have been documented. Studies of salamanders or amphibians as a group have found that clearcutting can reduce abundance (Blymer and McGinnes, 1977; Bury, 1983; Herrington and Larsen, 1985; Enge and Marion, 1986; Pough et al., 1987; Ash, 1988; Bury and Corn, 1988; DeGraaf and Yamasaki, 1992; Petranka et al., 1993, 1994; DuPuis et al., 1995; Ash, 1997; Clawson et al., 1997; Sattler and Reichenbach, 1998; Harpole and Haas, 1999), biomass (Bury, 1983; Enge and Marion, 1986), species richness (Blymer and McGinnes, 1977; Petranka et al., 1993; Clawson et al., 1997; deMaynadier and Hunter Jr., 1998), density (Petranka et al., 1993; Clawson et al., 1997; Ash, 1997), and rates/levels of detection or capture (Perison et al., 1997; deMaynadier and Hunter Jr., 1998; Sattler and Reichenbach, 1998). Clearcutting also can affect age structure of populations (Ash, 1997; Sattler and Reichenbach, 1998) and destroy salamander burrows, potentially affecting population persistence (Dodd Jr., 1991). This harvesting method also may reduce invertebrate biomass (Duguay et al., 2000; Duguay and Wood, 2002), which could indirectly affect amphibian survival. Mountaintop removal may have similar consequences 
because forests are also removed with this type of mining. Further, mountaintop removal mining may be even more detrimental to herpetofaunal populations because with this mining method, adjacent streams are buried in valley fills and soil disturbance is more extensive and more severe than with clearcutting.

$\underline{\text { Justification }}$

More scientific research about effects of mountaintop removal mining are greatly needed. Of the articles published on this topic, few are peer-reviewed technical papers. Most sources of information on this topic are in popular literature (e.g. Audubon), gray literature, and brochures or pamphlets published by coal companies. Local newspapers (e.g., The Charleston Gaze tte) have given considerable attention to mountaintop removal mining, including those newspapers produced by grassroots organizations (e.g., The Highlands Voice), such as the West Virginia Highlands Conservancy. Mountaintop removal mining has even been the subject of headlines in higher profile newspapers such as The New York Times (Anonymous, 2002).

Information presented in many of these sources conflict with each other and much of it appears to be biased. For example, estimates of the linear mileage of streams buried under valley fills in West Virginia ranges from hundreds of kilometers (Loeb, 1997) to thousands of kilometers (Abramson, 2001). Time estimated for forest re-establishment on reclaimed mountaintop removal mine sites spans from 150-200 years (Abramson, 2001) to 1000 years (Gilliam, 1998). Opinions range from mined land being better in some ways (Abramson, 2001) or $200 \%$ better than the undisturbed, natural state of the land prior to mining (Williams, 2001) to mountaintop removal mining being described as "the most flagrant form of environmental abuse in the country," and reclamation of these sites being akin to "putting lipstick on a corpse" (Abramson, 2001). These contradicting assessments are due in part to the absence of real data their collection and analyses. Proponents for and opponents against mountaintop mining have had to rely on speculation to support their positions. Clearly, there is a call for for unbiased, well-designed scientific studies of effects of mountaintop removal mining on natural resources. $\underline{\text { Objectives }}$

Overall, there were four objectives to this study:

1. To evaluate habitat use of reclaimed mountaintop removal mine habitat for herpetofauna by comparing herpetofaunal species richness and abundance among unmined native habitats and 
habitats on reclaimed mountaintop removal mines and between on-mine and off-mine grassland and shrub-pole habitats.

2. To determine effects of edge created by mountaintop removal mining operations on salamanders.

3. To examine habitat use of reclaimed mountaintop removal mine habitat and unmined habitat by salamanders by comparing their relative abundance among treatments.

4. To compare habitat use between valley fill streams and reference streams based on streamside salamander abundance and habitat characteristics.

Hypotheses

1. Herpetofaunal species richness and abundance does not differ among unmined native habitats and habitats on reclaimed mountaintop removal mines or between on-mine and off-mine grassland and shrub-pole habitats.

2. There are no effects of edge created by mountaintop removal mining operations on salamanders.

3. There is no difference in habitat use by salamanders among reclaimed mountaintop removal mine habitat and unmined habitat.

4. Salamander abundance and habitat characteristics do not differ between valley fill streams and reference streams.

\section{Description of Study Area}

Study Area

Study areas were located on and near three mountaintop removal mines in southwestern West Virginia: Hobet 21, Cannelton, and Dal-Tex (Figures 1-7). These mines were located in Boone, Kanawha and Fayette, and Logan counties, and in Mud River and Little Coal River, Twentymile Creek, and Spruce Fork watersheds, respectively. They had considerable distance between them (over a hundred miles between Dal Tex and Cannelton Mines) to provide geographical perspective (Hall et al., 1978). Intact forest reference areas were within several miles of the mines, with the exception of one that was located approximately 30 miles northeast of Cannelton Mine, on the border of Clay and Nicholas counties. All sampling points were established within close proximity to water quality sampling points established by EPA, and the closest water quality sampling point located within an intact forest near Cannelton Mine was 
about 30 miles from the mine. Study sites were located within the Allegheny Plateau physiographic province, which was characterized by moderate to strong relief and contained central hardwood forests (Strausbaugh and Core, 1977). Habitat types on the mines included reclaimed grasslands, reclaimed shrub-pole, and forest fragments with reclaimed habitats covering 2431, 1819, and 2180 ha (Balcerzak and Wood, 2003).

Early successional off-mine habitats structurally similar to reclaimed grassland and reclaimed shrub-pole habitats were also located in southern West Virginia on Wildlife Management Areas (WMAs) and private property (Figures 6-7). Grassland and shrub-pole habitats generated from non-mining disturbance are rare in West Virginia; the only plots that I found in the study area that I was granted permission to access and that would be relatively undisturbed by humans were considerably smaller than the on-mine grassland and shrub-pole habitats. Fork Creek WMA, 1.6 km northeast of Nellis in Boone County, contained approximately 1 ha each of grassland and shrub-pole areas. Private property that I surveyed on Camp Creek Road is also in Boone County and was 1.28 ha. Mud River WMA is in Lincoln County, as was another private property that I surveyed; this private property abutted Mud River WMA. Total grassland area in Mud River WMA was 80 ha, and shrub-pole habitat only occurred in a few areas that were less than 1 ha each. The off-mine grassland sampling point on private property near Mud River WMA was 0.39 ha.

\section{Native Habitat}

Fragmented and intact forests contained 60-80 year-old, second-growth, mature hardwoods. Overstory species included tuliptree (Liriodendron tulipifera), red and sugar maples (Acer rubrum and A. saccharum), American sycamore (Plantanus occidentalis), northern red, white, and black oaks (Quercus rubra, Q. alba, and Q. velutina); pignut, bitternut, and shagbark hickories (Carya glabra, C. cordiformis, and C. ovata); American beech (Fagus grandifolia), white ash (Fraxinus americana), and black birch (Betula lenta; Chap 2). Understory species (seedlings, saplings, poles) included black gum (Nyssa sylvatica), flowering dogwood (Cornus florida), ironwood (Carpinus caroliniana), spicebush (Lindera benzoin), and other common hardwood species, including the aforementioned overstory species (Chap 2). Percent cover by forest in the counties of this study was: Boone (84\%), Kanawha (77\%), Logan (85\%), Fayette (85\%), Clay (87\%), and Nicholas (80\%; Griffith and Widmann, 2003). 
Off-mine grasslands contained grasses and forbs. Predominant grasses included deertongue grass (Panicum clandestinum), tall fescue (Festuca arundinacea), orchard grass (Dactylis glomerata), and broom sedge (Bromus inermis; Ammer, 2003). Some species present in lower numbers included timothy (Phleum pratense) and smooth brome (Ammer, 2003). Forbs included birdsfoot-trefoil (Lotus corniculatus), alfalfa (Medicago sativa), aster (Aster spp.), and crownvetch (Coronilla varia; Ammer, 2003). These grasslands sometimes contained a few shrub-pole species, mostly sourwood (Oxydendrum arboreum), pawpaw (Asimina triloba), spicebush (Lindera benzoin), and bladdernut (Staphylea trifolia; Chap 2).

As with reclaimed shrub-pole habitats, off-mine shrub-pole habitat contained shrub, sapling, and pole-sized stems. Predominant shrub-pole species included autumn olive (Elaeagnus umbellata), multiflora rose (Rosa multiflora), blackberry and raspberry (Rubus spp.), pawpaw, spicebush, greenbrier (Smilax spp.), box elder (Acer negundo), and ironwood (Carpinus caroliniana; Chap 2).

\section{Reclaimed Habitat}

Reclaimed grasslands ranged in age from 10-18 years post-reclamation (Table 1) and were in an arrested stage of succession. Because all of the understory, forest floor and soil were removed with mountaintop removal mining, this mining technique can be classified as a severe disturbance, such as those caused by landslides or glacier retreat (Oliver and Larson, 1996). Patterns of stand development that normally occur after disturbances in forests have not yet begun in these reclaimed grasslands. Forests in the central Appalachians are often dominated by tree regeneration within 5 years post-disturbance clearcuts and within 10 years, an overstory canopy of trees over 20 feet tall is common (Smith, 1977). Twenty years post-disturbance, reclaimed grasslands are not even dominated by tree regeneration.

Predominant grasses included tall fescue, orchard grass, broomsedge (Andropogon virginicus), perennial ryegrass (Lolium perenne), hair grass and redtop (Agrostis scabra and A. stolonifera), timothy, and smooth brome (Wood and Edwards, 2001). Forbs included birdsfoot trefoil, alfalfa, sericea and bicolor lespedezas (Lespedeza cuneata and L. bicolor), red clover (Trifolium pratense), golden rod (Solidago spp.), sweetclover (Melilotus spp.), aster, wild lettuce (Lactuca virosa), fleabane (Erigeron canadensis), plantain (Plantago spp.), crownvetch and sedge (Carex spp.; Wood and Edwards, 2001). Grasslands sometimes contained a few shrub species, mostly planted autumn olive and multi-flora rose (Wood and Edwards, 2001). 
Reclaimed shrub-pole habitats contained shrub, sapling, and pole-sized stems and were 18-28 years old (Table 1). I used vegetation to define reclaimed treatments because reclamation age of grassland and shrub-pole treatments overlapped. Predominant shrub-pole species in this treatment included autumn olive, multiflora rose, red maple, American sycamore, tuliptree, European black alder (Alnus glutinosa), blackberry and raspberry, sourwood, black locust (Robinia pseudoacacia), and scotch and white pines (Pinus sylvestris and P. strobus; Wood and Edwards, 2001). Many of the grass and forb species found in the grassland treatment also occurred in reclaimed shrub-pole habitats.

Soils

Native soils tended to be deep, well drained, steep (Van Houten et al., 1981; Wolf 1994), and had high percent cover by leaf litter (Chap 2). Thomas et al. (2000) sampled minesoils on Dal-Tex Mine and found that average sola depth (combined thickness of A, AC, and Bw horizons) was $97 \mathrm{~cm}$ in native soils and all native soils sampled had $\mathrm{O}$ horizons. These authors did not analyze their results statistically and compared 3 native soil pits to 24 minesoil pits (6 pits for each of 4 age classes), but their study is the only one of its kind that I found.

On Dal-Tex Mine, Thomas et al. (2000) also observed young minesoils to show little to no profile development and a 23-year-old minesoil that showed some development of weak B horizons. Newly reclaimed minesoils have low organic matter content due to destruction of A horizons (Stephens et al., 2001). However, A horizons of minesoils increase with time and can become deeper than native soils in as little as 7 years, according to Thomas et al. (2000), which they attributed to the seeding of grasses and legumes during reclamation. A horizons are the topmost mineral horizons and they contain some organic matter (Thomas et al., 2000). While O horizons (organic horizons above mineral soil) sometimes develop within minesoils 2 years of age, minesoils up to 11 years old may not have any (Tho mas et al., 2000). Average sola depth ranged from $12 \mathrm{~cm}$ (2 year-old reclaimed) to $31 \mathrm{~cm}$ (23 year-old reclaimed) on reclaimed soils (Thomas et al., 2000). Surface rock fragment content of minesoils showed no pattern due to age of minesoil; 11-year-old minesoils had a higher content than 23-year-old minesoils, but 2-yearold rock fragment content was lower than that in 23-year-old minesoils (Thomas et al., 2000). Thomas et al. (2000) suspected that these differences were due to variability in blasting and reclamation techniques. 
Native soils had an average water-stable aggregation of $63 \%$ in their surface horizons and $62 \%$ in their subsurface horizons, compared to $31-56 \%$ in surface horizons and $12-54 \%$ in subsurface horizons of minesoils ranging in age from 2 to 23 years. Aggregation is a measure of stability and "expresses the resistance of soil structural aggregates to breakdown when subjected to disruptive processes (Thomas et al., 2000).

\section{County Descriptions}

\section{Climate}

Boone, Kanawha, and Nicholas counties have winters with lasting cold and snow in high elevations and frequent cold and snows of short duration in the valleys (Van Houten et al., 1981; Carpenter, 1992; Wolf, 1994). (Soil surveys are not yet published or are out-of-date for Logan, Lincoln, Fayette, and Clay counties.) The average winter temperatures in these counties are 0.5$2^{\circ} \mathrm{C}$ while the average summer temperatures are $21-23^{\circ} \mathrm{C}$. Commonly, the last freezing temperature of the spring comes the last few days of April or the first few days of May, while the first freezing temperature of the fall most often comes around the end of the second week or the beginning of the third week of October.

Total annual precipitation in Boone County is $112 \mathrm{~cm}$, on average (Wolf, 1994), while average annual precipitation for Kanawha and Nicholas counties is $104 \mathrm{~cm}$ (Van Houten et al., 1981) and $119 \mathrm{~cm}$ (Carpenter, 1992), respectively. Of these amounts, 54-55\% falls from April through September, which constitutes the growing season for most crops in these areas. Average snowfall is about $58 \mathrm{~cm}$ in Boone County (Wolf, 1994), $76 \mathrm{~cm}$ in Kanawha County (Van Houten et al., 1981), and $127 \mathrm{~cm}$ in Nicholas County. Average relative humidity for these counties is roughly 55\% in midafternoon and 80\% at dawn (Van Houten et al., 1981; Carpenter, 1992; Wolf, 1994).

\section{Soil Mapping Units}

In this section, I presented soil mapping unit information at each drift fence array sampling point for which current soil survey information is available. The two fragmented forest treatments on Hobet 21 Mine and the intact forest near were of the Berks-Shelocta soil formation, which consists of steep and extremely stony soils on mountains in areas where siltstone bedrock is abundant (Wolf, 1994). The Berks soil frequently occurs on ridgetops and upper side slopes, while the Shelocta soil is often found on middle and lower side slopes, on foot 
slopes, and in coves. Slope ranges from 35 to $80 \%$ and relief ranges from approximately 183 to $396 \mathrm{~m}$.

Berks and similar soils dominate most (40\%) of the Berks-Shelocta unit, while Shelocta and similar soils make up 35\% (Wolf, 1994). The remainder of this soil formation (25\%) is made of minor soils and rock outcrops. The Berks soil is moderately deep and well drained and the Shelocta soil is deep and well drained. Typically, the surface layer of Berks soil is dark brown channery loam, about $5 \mathrm{~cm}$ thick. Similarly, Shelocta surface layers are dark brown channery silt loam about $8 \mathrm{~cm}$ thick. Wolf (1994) defines channery as "a soil that is, by volume, more than $15 \%$ thin, flat fragments of sandstone, shale, slate, limestone, or schist as much as [15.24 cm] along the longest axis. A single piece is called a channer."

Berks subsoil is colored yellowish brown and is characterized as a channery loam in the upper part. At lower depths, the subsoil is yellowish brown and is an extremely channery silt loam. The subsoil extends approximately $58 \mathrm{~cm}$ before reaching bedrock. Shelocta subsoil is colored like Berks subsoil, but is a channery silt loam, channery silty clay loam, and channery silty clay loam to a minimum of $165 \mathrm{~cm}$ deep. Minor soils are dominated by Guyandotte, Gilpin, and Wharton soils, but also include Kaymine, Cedarcreek, and Sensabaugh.

Subsoil and substratum permeability is moderate or moderately rapid in the Berks soil and moderate in the Shelocta soil (Wolf, 1994). Available water capacity is low to moderate in Berks soils and moderate or high in Shelocta soils. Both soils have rapid runoff. Natural fertility tends to be low in Berks soils, but can be low to medium in Shelocta soils. The acidity of Berks soils varies according to depth. The surface layers are extremely acid to slightly acid, and in the subsoil and substratum, soils are extremely acid to moderately acid. Throughout the Shelocta soils, they are strongly acid or strongly acid. However, the surface layer of some Shelocta soils is less acid due to repeated burning. The depth to bedrock is 51 to $102 \mathrm{~cm}$ in Berks soils, but is considerably deeper in Shelocta soils at more than $152 \mathrm{~cm}$.

The reclaimed grassland on Hobet 21 had Kaymine and Kaymine-Rock outcrop complex soils, as did the reclaimed shrub-pole sampling point on this mine (Wolf, 1994). The reclaimed shrub-pole sampling point also had Kaymine-Cedarcreek-Dekalb complex soils.

The Kaymine-Rock outcrop complex largely consists of Kaymine soils (65\%). The remaining $35 \%$ is made up of Rock outcrop and other included soils, but because all of these components are so intermingled, they were mapped together (Wolf, 1994). Kaymine soils are 
channery loam and stony. Their slopes are not steep and range from 3-8\%, although some soils in this unit slope more than $8 \%$. The Kaymine-Rock outcrop complex soils are steep and extremely stony. Kaymine and Kaymine-Rock outcrop complex soils are deep and well drained and both are in areas that were surface mined for coal.

Kaymine soils generally are on mountaintops and on gently sloping hilltops and benches (Wolf, 1994). Kaymine-Rock outcrop complex soils commonly are on slopes of mountainsides by vertical or nearly vertical highwalls, gently sloping or strongly sloping benches, and steep outslopes. Highwalls, benches, and outslopes make up approximately 15\%, 25\%, and 60\% of the unit, respectively. Highwalls are about 8-30 m above bench floors. Percent slope of benches, which are usually concave, is $3-35 \%$. Percent slope of outslopes, which are typically convex, is $35-80 \%$. While stones and boulders cover only $1-3 \%$ of the surface in most areas of Kaymine soils, they cover 3-15\% of the surface on Kaymine-Rock outcrop complex soils.

Kaymine soil surface layers are dark gray channery loam approximately $13 \mathrm{~cm}$ thick; to a depth of at least $165 \mathrm{~cm}$, the substratum is dark gray extremely channery loam with siltstone, sandstone, and coal comprising 60\%, 30\%, and 10\% of rock fragments (Wolf, 1994). Rock outcrop soil mapping units consists of bedrock exposed by surface mining.

Kaymine soils include small areas of Cedarcreek, Fiveblock, Sewell soils, Gilpin, Wharton, Berks, Shelocta and sandy soils (Wolf, 1994). Together these areas make up about $20 \%$ of this unit. Included in Kaymine-Rock outcrop complex soils are Pineville, Berks, Dekalb, Cedarcreek, Fiveblock, and Itmann soils.

Permeability is moderate or moderately rapid in the Kaymine soil substratum; available water capacity is low to high; and runoff is medium (Wolf, 1994). Natural fertility is medium or high and the soil is moderately acid to mildly alkaline. Depth to bedrock exceeds $152 \mathrm{~cm}$.

The Kaymine-Cedarcreek-Dekalb complex contains well drained soils found on slopes of mountainsides (Wolf, 1994). Kaymine and Cedarcreek soils are deep and Dekalb soils are moderately deep. Kaymine and Cedarcreek soils are in areas that were surface mined for coal, while Dekalb soils are on unmined side slopes. Slopes of Kaymine and Cedarcreek soils are gentle or strongly sloped on benches and steep or steep on outslopes. Additionally, they are adjacent to nearly vertical highwalls. Dekalb soils are steep; slopes range from 3-35\% on benches and from $35-80 \%$ on outslopes and side slopes. In surface mined areas of the Kaymine- 
Cedarcreek-Dekalb complex, stones and boulders cover 3-15\%, highwalls, 15\%; benches, 25\%; and outslopes, $60 \%$.

Kaymine and similar soils constitute the majority (35\%) of the Kaymine-CedarcreekDekalb complex, but there was a fairly even distribution of other soils: $25 \%$ Cedarcreek and similar soils, 20\% Dekalb and similar soils, and 20\% included soils (Wolf, 1994). Kaymine soil surface layers are dark gray channery loam about $13 \mathrm{~cm}$ thick and Cedarcreek soil surface layers tend to be about $8 \mathrm{~cm}$ thick. Kaymine soil substratum is dark gray extremely channery loam to a depth of at least $165 \mathrm{~cm}$ and has rock fragments consisting of 60\% siltstone, 30\% sandstone, and $10 \%$ coal. Cedarcreek subsoil is yellowish brown channery sandy loam and extends $61 \mathrm{~cm}$ until it meets bedrock.

The Kaymine-Cedarcreek-Dekalb complex soils are also mapped with a few areas of rock outcrop on vertical highwalls (Wolf, 1994). This mapping unit also contains Berks, Dekalb, Kaymine, Sewell, Pineville, Guyandotte, and Itmann soils, as well as a few other soil types. Cedarcreek substratum permeability is moderate or moderately rapid in the substratum and available water capacity is low to high. In Dekalb soils, subsoil and substratum permeability is rapid. Natural fertility is low or medium in Cedarcreek soils and low in Dekalb soils. Runoff is rapid on Cedarcreek outslopes and in Dekalb soils, and is medium or rapid on Cedarcreek benches. Cedarcreek soils and Dekalb substratum and subsoils are extremely acid to strongly acid, and is extremely acid to slightly acid in Dekalb surface layers.

A reclaimed grassland sampling point and a fragmented forest sampling point on the Cannelton Mine both had soils from the Clymer-Dekalb complex (Van Houten et al., 1981). These soils are steep and are well drained. They are also deep or moderately deep and have slopes ranging from 40-70\%. Most of this complex is Clymer channery loam ( 40\%), while $35 \%$ is Dekalb channery sandy loam. Soils of minor extent constitute $25 \%$ of this soil mapping unit.

Clymer soil surface layers are dark grayish brown and yellowish brown channery loam; they tend to be about $10 \mathrm{~cm}$ thick (Van Houten et al., 1981). Dekalb soils are colored black and brown on the surface layer and consist of about $8 \mathrm{~cm}$ thick channery sandy loam. Clymer subsoil is friable (refers to the ease with which moist soil can be crumbled; Plaster, 1997) and goes to a depth of $94 \mathrm{~cm}$, of which the upper $20 \mathrm{~cm}$ is yellowish brown channery loam; the next $51 \mathrm{~cm}$ is strong brown channery clay loam; and the bottom layer is strong brown channery light clay 
loam. The substratum of the Clymer soils is a mixture of strong brown and yellowish red channery light clay loam and is about $38 \mathrm{~cm}$ thick. Sandstone and shale bedrock are at a depth of 52 inches. Dekalb subsoil is pale brown and extends to a depth of approximately $68 \mathrm{~cm}$, of which the upper $18 \mathrm{~cm}$ is friable channery sandy loam; the next $25 \mathrm{~cm}$ is firm channery sandy loam; and the lower $25 \mathrm{~cm}$ is firm channery sandy loam coated with yellowish red. Below the subsoil at a depth of approximately $76 \mathrm{~cm}$ is sandstone bedrock.

The Clymer-Dekalb complex is mapped with Gilpin and Laidig soils, as well as stony soils and rock outcrop (Van Houten et al., 1981). Clymer soil permeability is moderate to moderately rapid and its available water capacity is moderate to high. Dekalb soil permeability is moderately rapid to rapid and its available water capacity is low to moderate. Bedrock restricts the root zone in Clymer soils at a depth of more than $102 \mathrm{~cm}$ and in Dekalb soils at a depth of 51 to $102 \mathrm{~cm}$. In unlimed areas of both Clymer and Dekalb soils, the surface layer and subsoil are often strongly acid or strongly acid. Runoff is rapid and erosion hazard is severe in the Clymer-Dekalb complex. Natural fertility is moderate in the Clymer soil and low in the Dekalb soil; some areas of this soil complex are strip mined.

The intact forest point near Cannelton Mine contained Buchanan channery fine sandy loam and Gilpin-Pineville-Guyandotte association soils (Carpenter, 1992). Buchanan channery fine sandy loam has moderately steep and steep slopes (15-35\% slopes) and is stony and moderately well drained. The Gilpin-Pineville-Guyandotte association is steep (35-70\%) and is stony and well drained. While Buchanan channery fine sandy loam occurs on foot slopes and benches, along drainageways, and in coves, the Gilpin-Pineville-Guyandotte association is found on mountain side slopes. More specifically, Gilpin soils are often on convex upper and middle slopes; Pineville soils are on lower side slopes, in south-facing coves, and on foot slopes; and Guyandotte soils are on concave, north-facing side slopes, in coves, and on foot slopes. Stones cover $3-15 \%$ of the surface in both Buchanan channery fine sandy loam and the Gilpin-PinevilleGuyandotte association.

The surface layer of the Buchanan channery fine sandy loam mapping unit is typically dark grayish brown and brown channery fine sandy loam about $18 \mathrm{~cm}$ thick (Carpenter, 1992). Gilpin soils are moderately deep, and Pineville and Guyandotte soils are deep. The Gilpin, Pineville, and Guyandotte soil surface layer are 8, 10, and $28 \mathrm{~cm}$ thick, respectively. Gilpin surface layers are usually dark brown silt loam. The surface layer of Pineville soils is typically 
dark brown channery silt loam and Guyandotte surface soil layers have dark brown and dark brown channery silt loam.

Buchanan channery fine sandy loam subsoil extends to a depth of about $152 \mathrm{~cm}$ (Carpenter, 1992). The upper $33 \mathrm{~cm}$ of the subsoil is yellowish brown channery loam. Below this is $102 \mathrm{~cm}$ of firm or firm and brittle soil, of which $20 \mathrm{~cm}$ is yellowish brown channery loam mottled with light brownish gray and $81 \mathrm{~cm}$ is yellowish brown channery loam mottled with light brownish gray. To a depth of at least $165 \mathrm{~cm}$, the substratum is light yellowish brown channery sandy loam.

The Gilpin subsoil extends to a depth of about $69 \mathrm{~cm}$ (Carpenter, 1992). This subsoil contains approximately $20 \mathrm{~cm}$ of yellowish brown silt loam, $25 \mathrm{~cm}$ of yellowish brown channery silt loam, and $15 \mathrm{~cm}$ of yellowish brown channery loam. Gilpin substratum is colored yellowish brown and is a channery loam; it extends to bedrock at a depth of about $86 \mathrm{~cm}$. The Pineville subsoil extends to a depth of about $135 \mathrm{~cm}$, of which about $97 \mathrm{~cm}$ is yellowish brown channery loam and $28 \mathrm{~cm}$ is yellowish brown channery loam. Pineville substratum is colored yellowish brown and brownish yellow with light brownish gray and extends to bedrock substratum to a depth of about $165 \mathrm{~cm}$. The Guyandotte subsoil extends to a depth of about 165 $\mathrm{cm}$, of which about $8 \mathrm{~cm}$ is dark yellowish brown channery loam; $97 \mathrm{~cm}$ is yellowish brown channery loam; and $33 \mathrm{~cm}$ is yellowish brown extremely channery loam.

The Buchanan channery fine sandy loam is mapped with Dekalb, Gilpin, Lily, and Pineville soils (Carpenter, 1992). Of this map unit, 30\% of it includes soils that are deeper to a fragipan than the Buchanan soil, soils that contain less than $1 \%$ of surface cover by stones, soils that have $15-50 \%$ of their surfaces covered with stones and boulders, and soils with $>15 \%$ slopes. A fragipan is defined as "a loamy, brittle subsurface horizon low in porosity and content of organic matter and low or moderate in clay but high in silt or fine sand. A fragipan appears cemented and restricts roots. When dry, it is hard or hard and has a higher bulk density than the horizon or horizons above. When moist, it tends to rupture suddenly under pressure rather than to deform slowly (Carpenter, 1992)."

The Gilpin-Pineville-Guyandotte association is made of about $40 \%$ Gilpin and similar soils, 30\% Pineville and similar soils, 15\% Guyandotte and similar soils, and 15\% soils of minor extent (Carpenter, 1992). Thirty percent of this mapping unit includes areas of Dekalb, Lily, and 
Buchanan soils, as well as rock outcrops, slopes $<35 \%$, and areas with $<3 \%$ or $>15 \%$ of stone and boulder surface cover.

The available water capacity is moderate for Buchanan and Gilpin soils, is moderate or high in Pineville soils, and is low to high for Guyandotte soils (Carpenter, 1992). Permeability is slow in Buchanan soils. Permeability is moderate in the Gilpin soil and in the Pineville subsoil and is moderate or moderately rapid in Guyandotte soils. Runoff is rapid or rapid in Buchanan soils and rapid in the Gilpin-Pineville-Guyandotte association. Natural fertility is medium in both the Buchanan channery fine sandy loam and in the Gilpin-Pineville-Guyandotte association. The Buchanan soil mapping unit contains a seasonal high water table, which inhibits root growth of water-sensitive plants. Gilpin soils and unlimed Buchanan soils are strongly acid to extremely acid. Pineville soils are strongly acid or strongly acid. Acidity differs with depth of Guyandotte soils. In their surface layers, reaction ranges from strongly acid to neutral, while their subsoils and substratums are strongly acid to moderately acid.

Depth to bedrock is more than $152 \mathrm{~cm}$ in Buchanan, Pineville, and Guyandotte soils and ranges from 51 to $102 \mathrm{~cm}$ in Gilpin soils. Erosion hazard is severe in Buchanan channery fine sandy loam and in the Gilpin-Pineville-Guyandotte association.

The off- mine shrub-pole sampling point on Camp Creek Road contained SensabaughLobdell loams (Wolf, 1994). Slopes in this mapping unit are nearly level or are gently sloping, with 2-8\% slopes. More specifically, Sensabaugh soils are in gently sloping areas, and Lobdell soils tend to be on the more level flood plains. Soils in this mapping unit are well drained and moderately well drained and are on bottomlands in narrow drainageways that experience infrequent flooding. This unit consists of 45\% Sensabaugh soil, 35\% Lobdell soil, and 20\% included soils, such as Potomac, Chagrin, Allegheny, Kanawha, and Pineville soils (Wolf, 1994). Additionally, this mapping unit includes a few areas of soils that are: 1) strongly acid or very strongly acid, 2) freque ntly flooded or occasionally flooded, and 3) poorly drained.

Sensabaugh surface layers are dark grayish brown loam about $15 \mathrm{~cm}$ thick and Lobdell surface layers contain a dark brown loam about $20 \mathrm{~cm}$ thick (Wolf, 1994). Below the surface layers of the Sensabaugh soils is about $13 \mathrm{~cm}$ of brown gravelly loam. Sensabaugh subsoil is dark yellowish brown gravelly loam and about $74 \mathrm{~cm}$ thick and Lobdell subsoil is brown loam approximately $48 \mathrm{~cm}$ thick with light brownish gray and yellowish brown mottles at lower depths. Sensabaugh substratum, to a depth of at least $165 \mathrm{~cm}$, is dark yellowish brown gravelly 
loam and Lobdell substratum is light brownish gray fine sandy loam and loam mottled with strong brown. Sensabaugh substratum also has a few strong brown and pale brown mottles below a depth of $140 \mathrm{~cm}$.

Permeability is moderate or moderately rapid in the subsoil and substratum of the Sensabaugh soil and in the substratum of the Lobdell soil (Wolf, 1994). Lobdell subsoil permeability is moderate. Available water capacity is moderate or high in Sensabaugh soils and high in Lobdell soils. Runoff is medium in Sensabaugh soils, but slow in Lobdell soils. Natural fertility is medium or high in the Sensabaugh-Lobdell mapping unit. In the absence of lime, Sensabaugh soil is moderately acid to neutral, Lobdell surface soil and subsoil are strongly acid to slightly acid, and Lobdell substratum is moderately acid or slightly acid. Depth to bedrock for both Sensabaugh and Lobdell soils is $152 \mathrm{~cm}$.

Lobdell soil has a seasonal high water table 61 to $107 \mathrm{~cm}$ below the surface, which restricts the root zone of some plants (Wolf, 1994). Diversions are sometimes needed to intercept runoff onto Lobdell soils from higher areas, as flooding can be a hazard on these soils. 

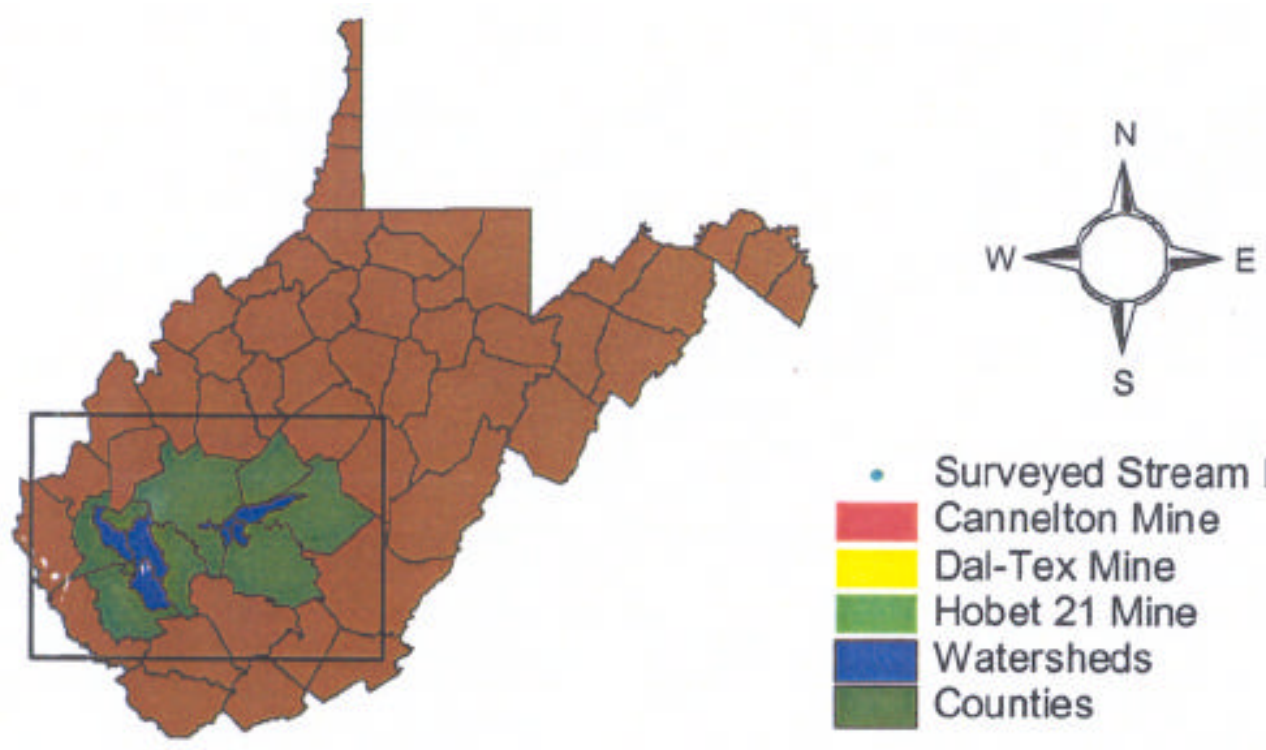

- Surveyed Stream Drainages Cannelton Mine Dal-Tex Mine Hobet 21 Mine Watersheds Counties

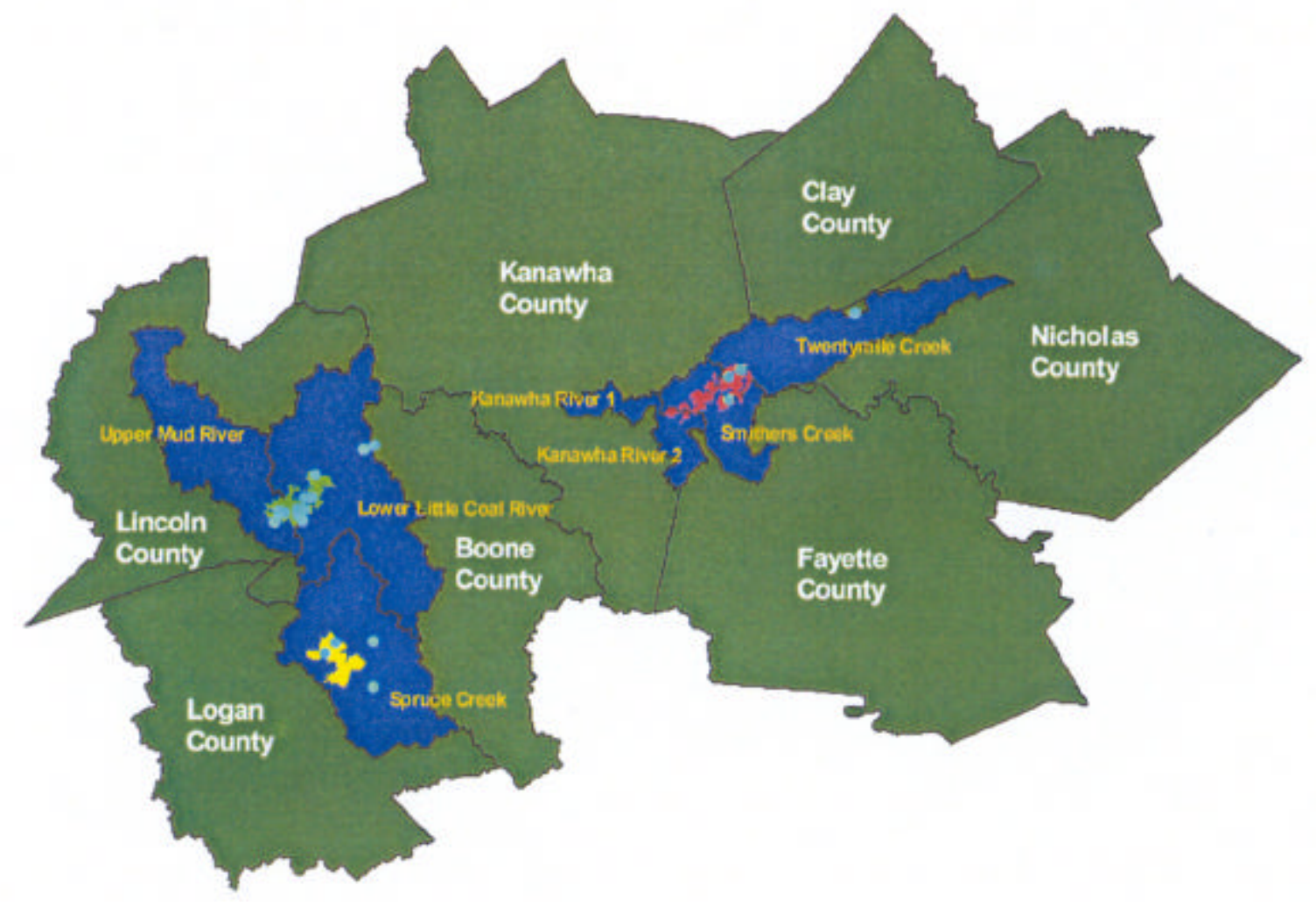

Figure 1. Location of mountaintop removal mine sites within watersheds in southern West Virginia. 


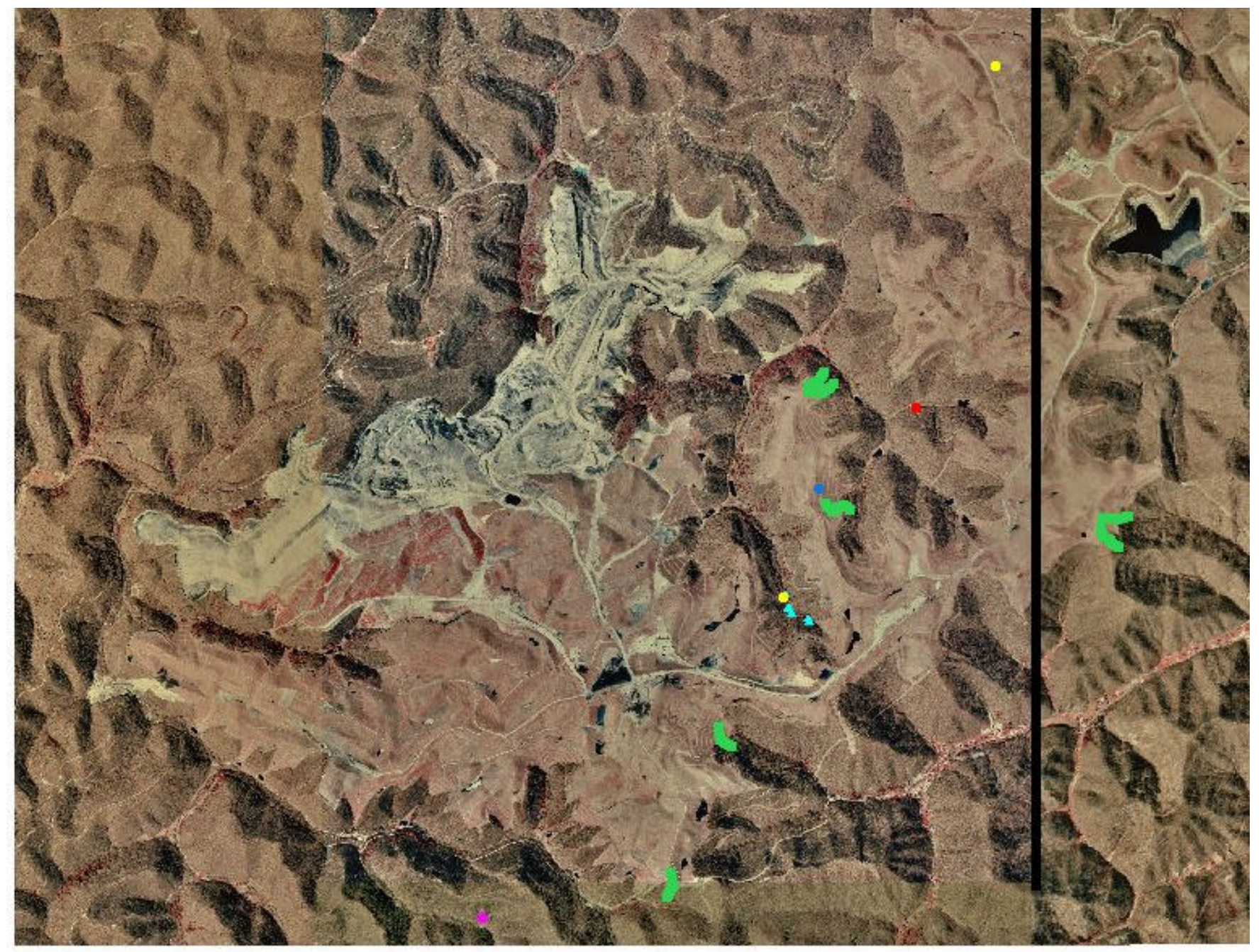

Fragmented forest drift fence array

- Valley fill stream transects

- Shrub / pole drift fence array

- Grassland drift fence array

- Intact forest drift fence array

- Coverboards

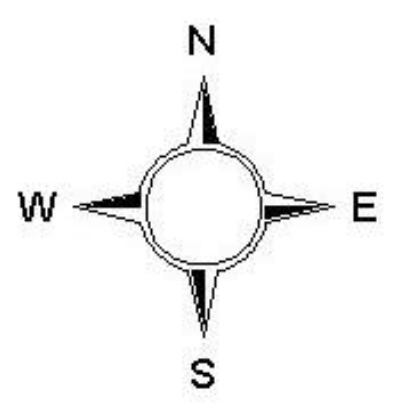

Figure 2. Aerial photograph of Hobet 21 mountaintop removal mine with locations of sampling points in Boone County, West Virginia. 


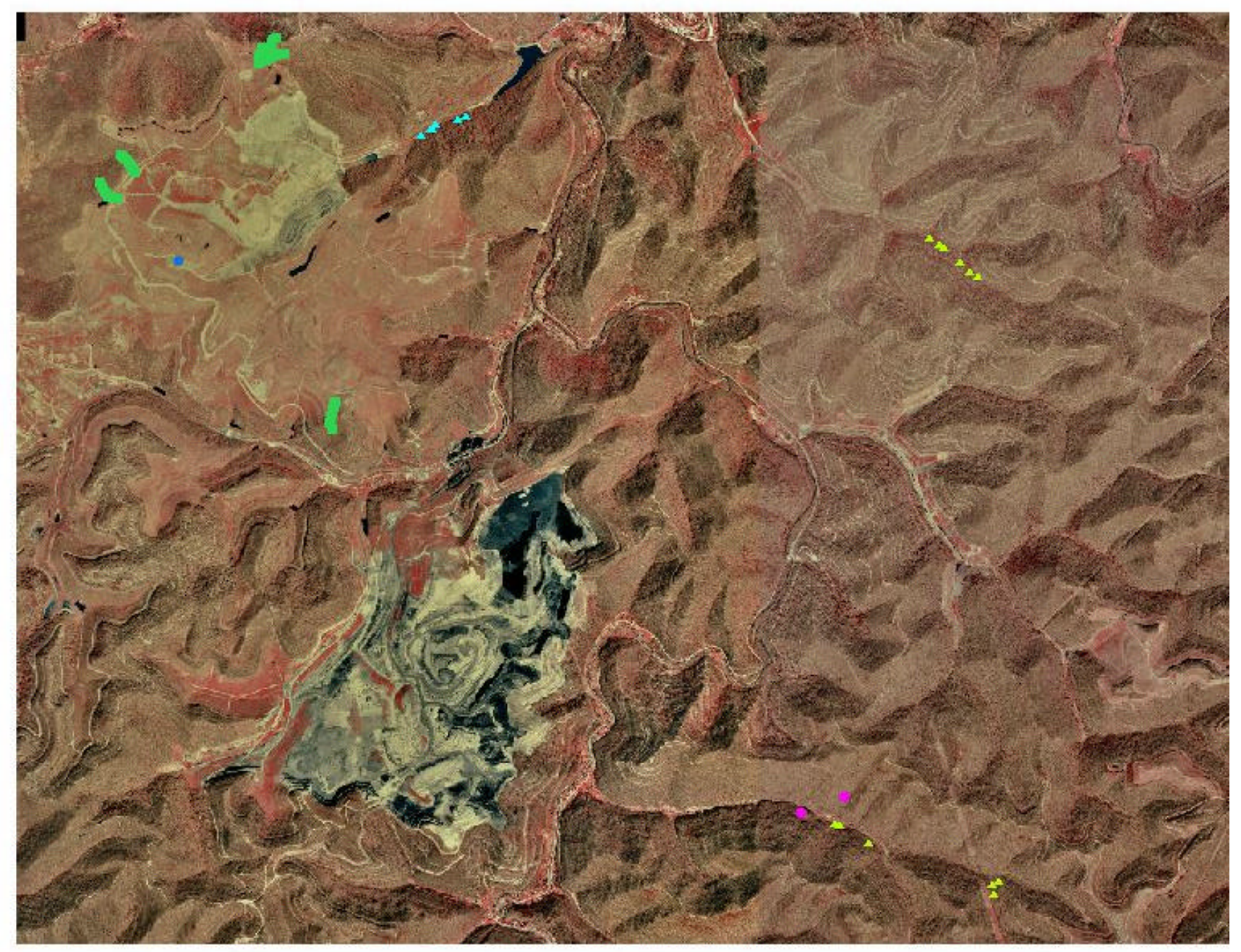

- Valley fill stream transects

- Grassland drift fence array

- Intact forest drift fence array

- Reference stream transects

- Coverboards

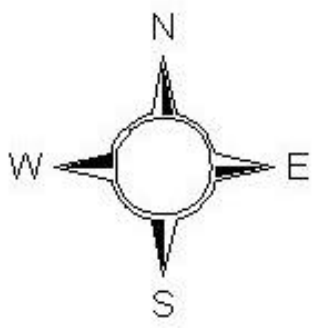

Figure 3. Aerial photograph of DalTex mountaintop removal mine with locations of sampling points in Logan County, West Virginia. 

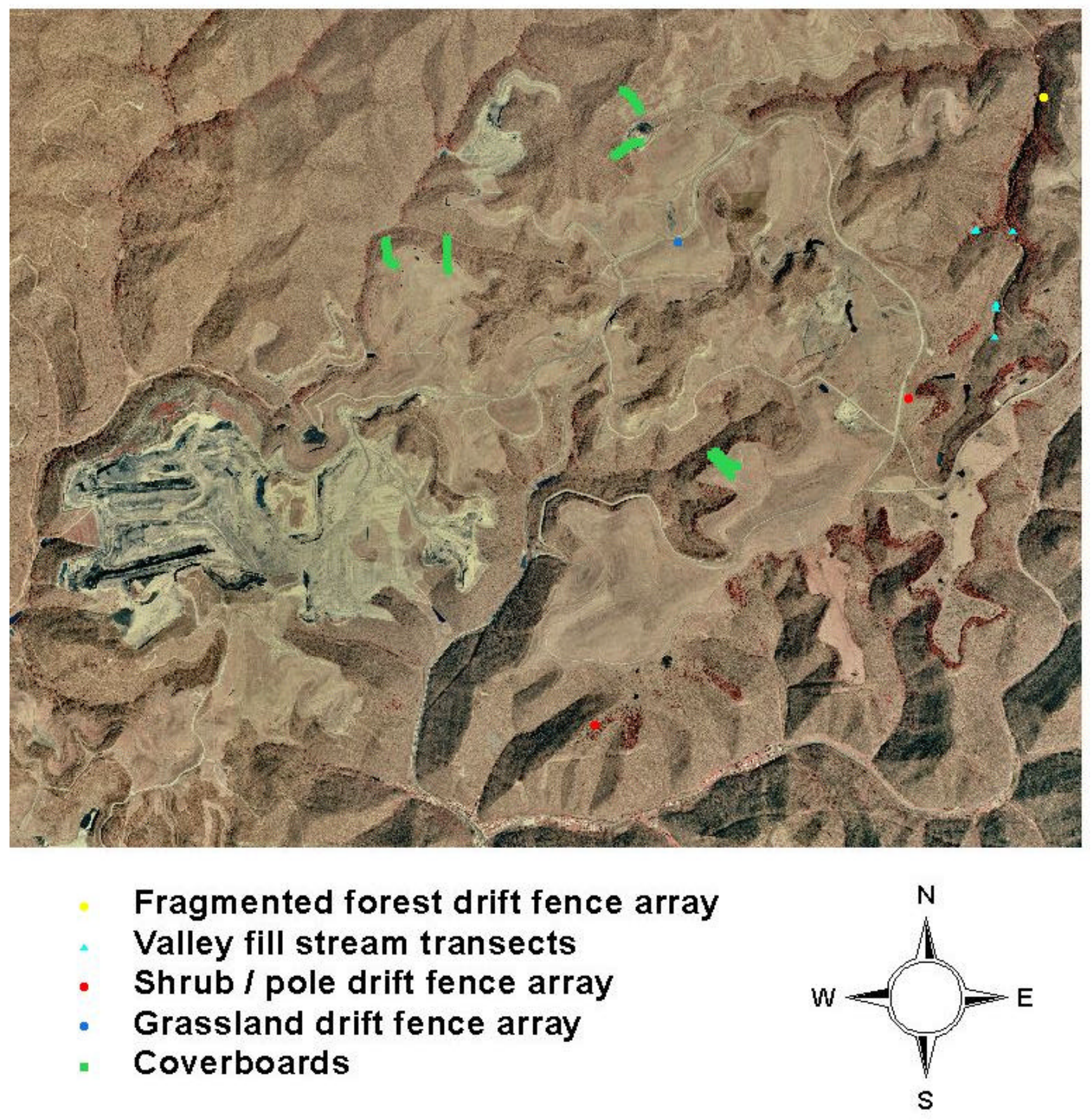

Figure 4. Aerial photograph of Cannelton mountaintop removal mine with locations of sampling points in Kanawha and Fayette counties, West Virginia. 


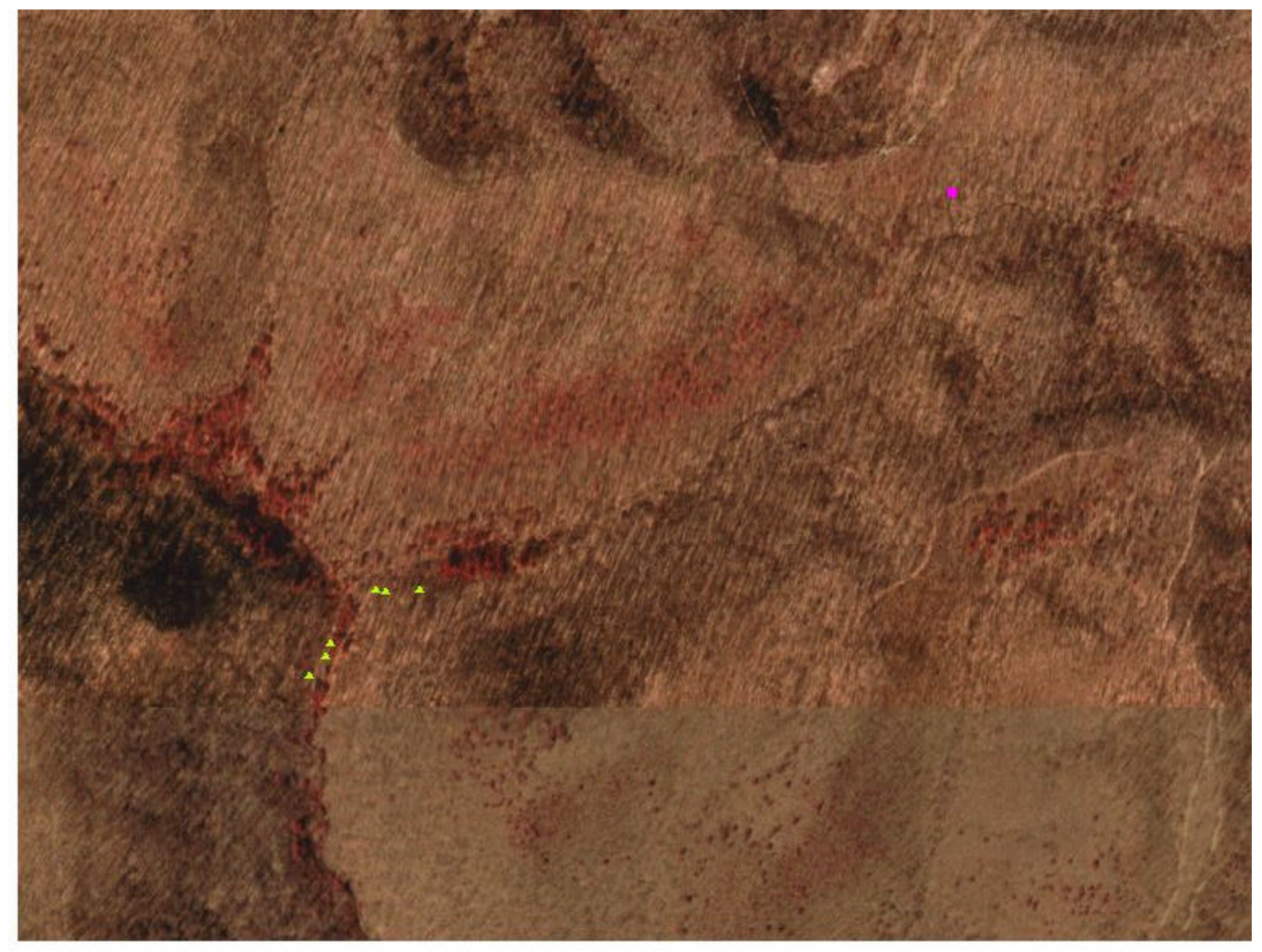

- Intact forest drift fence array - Reference stream transects
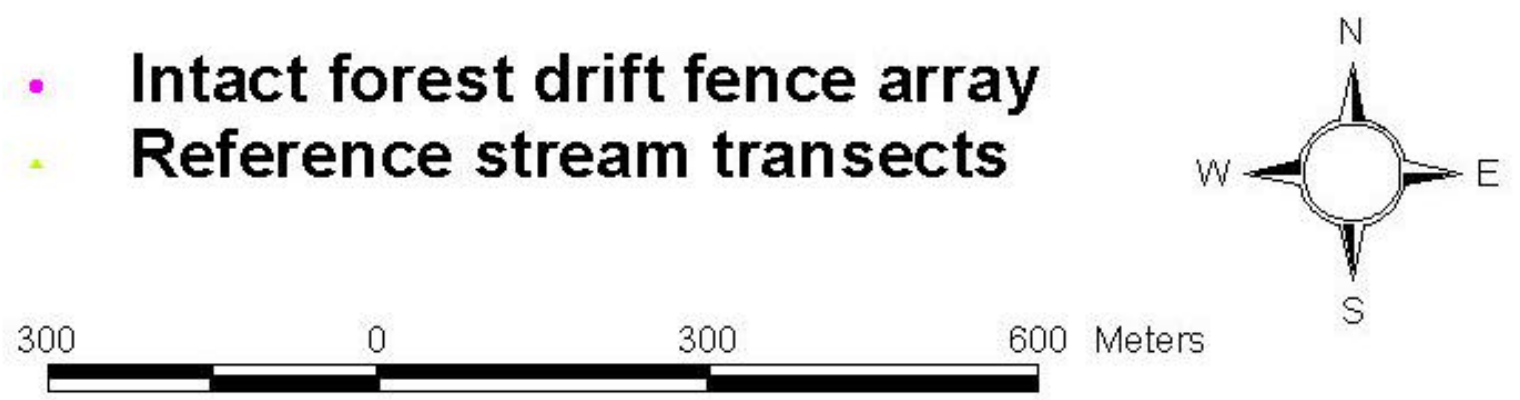

Figure 5. Aerial photograph of sampling points along Ash Fork in Nicholas County, West Virginia. 


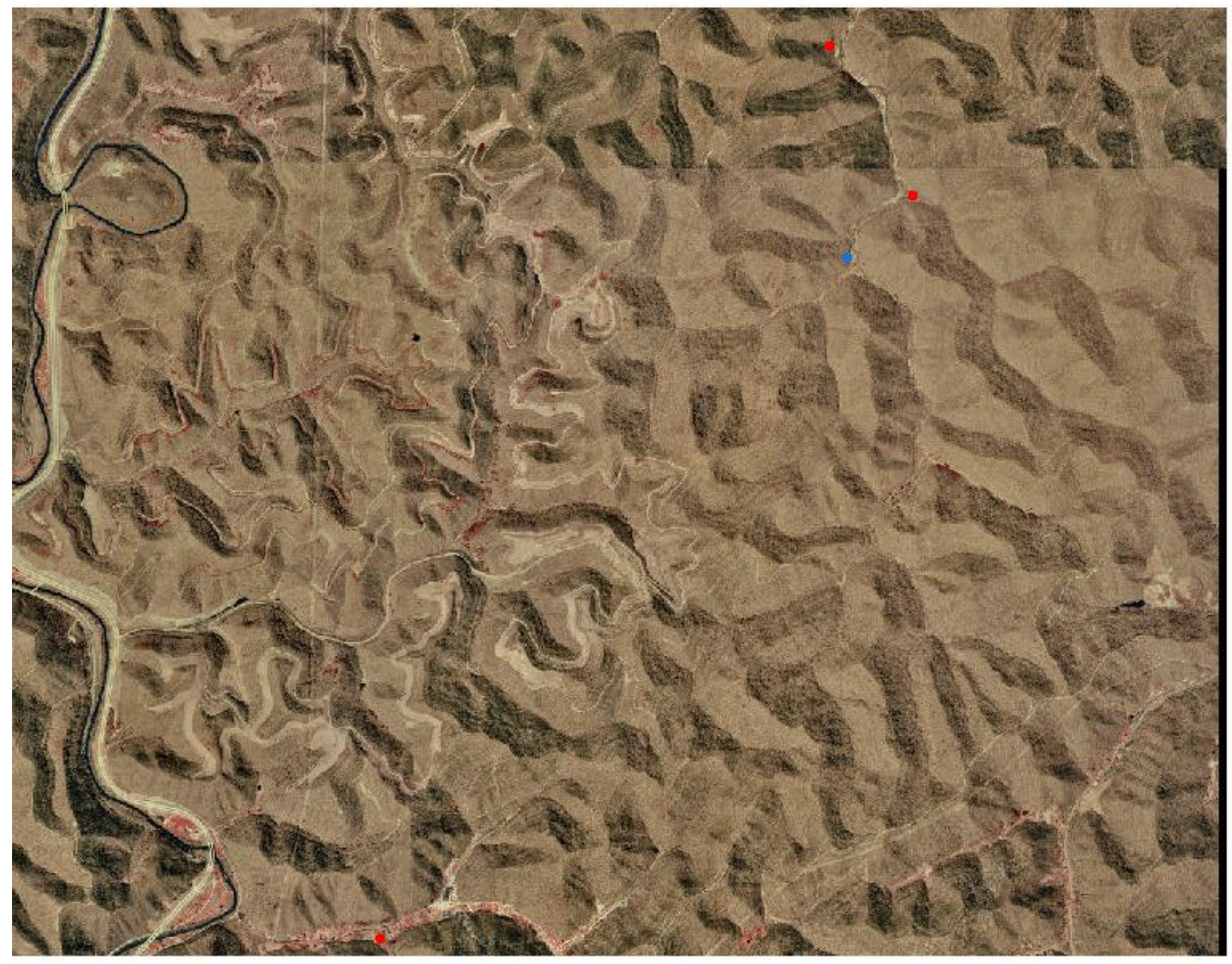

- Shrub / pole drift fence array

- Grassland drift fence array

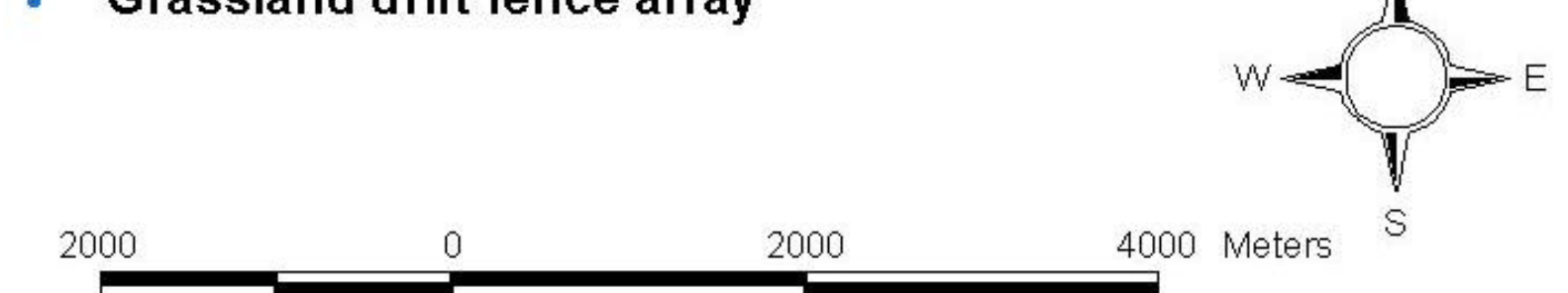

Figure 6. Aerial photograph of Fork Creek Wildlife Management Area and Camp Creek Road with locations of sampling points in Boone County, West Virginia. 


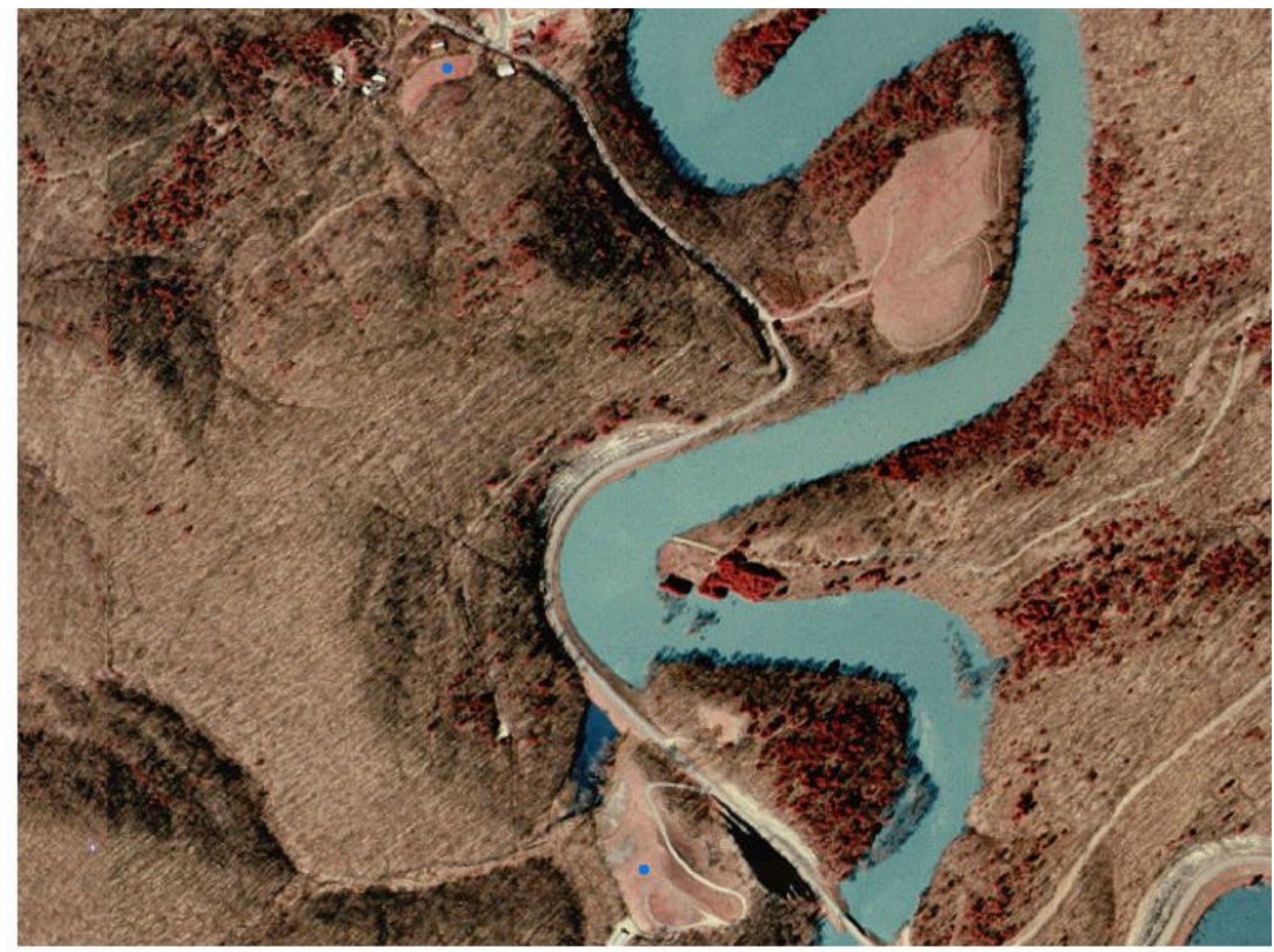

- Grassland drift fence array
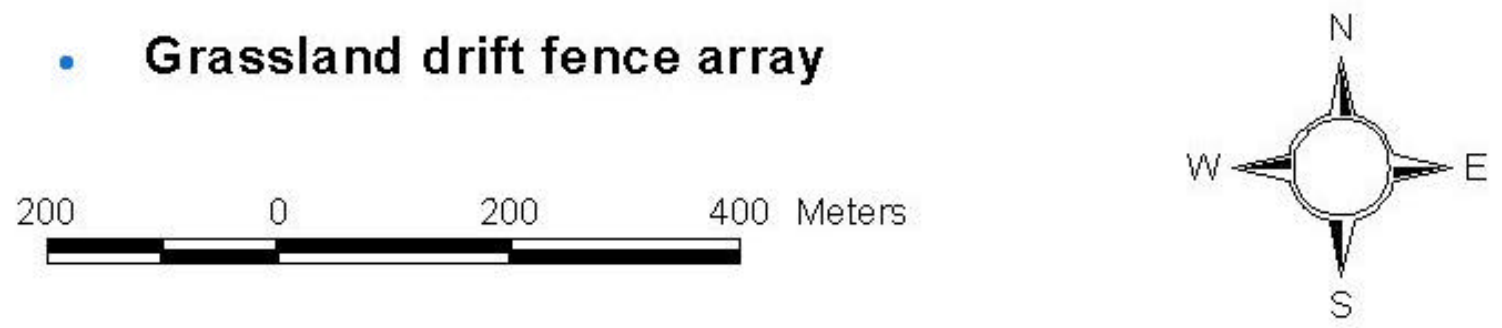

Figure 7. Aerial photograph of Mud River Wildlife Management Area with locations of sampling points in Lincoln County, West Virginia. 


\section{Chapter 2}

\section{Mountaintop Removal Mining and Its Impacts on Terrestrial Herpetofaunal Communities in Southern West Virginia}

[This chapter is formatted in the style of Conservation Biology]

Abstract: Mountaintop removal mining, a large-scale disturbance affecting vegetation and soil structure, converts large areas of eastern deciduous forest to early successional habitats in the southern Appalachians. I sampled terrestrial herpetofauna using drift fence arrays with pitfalls and funnel traps on and near mountaintop removal mines in southern West Virginia from 20002002. I compared relative abundance and species richness of herpetofauna among 4 treatments: unmined native forest habitat (intact forest) and habitats on reclaimed mountaintop removal mines (reclaimed grassland, reclaimed shrub-pole habitat, and fragmented forest) and between 2 treatments: early successional on-mine and off-mine habitats (grassland and shrub-pole). Reclaimed treatments had lower abundance and species richness of overall salamanders and lungless salamanders (Family Plethodontidae) than 1 or both forest treatments. Obligate terrestrial salamanders (genus Plethodon) had higher abundance levels in intact forests than in all other treatments. Snake abundance and species richness were greater in reclaimed treatments than in forested treatments. Anuran species richness and abundance did not differ among treatments; I did not conduct analyses on lizard and turtle species richness and abundance because their sample sizes were too small. These findings suggest that less mobile habitat specialists are unable or unwilling to use reclaimed mine habitats, but that some element(s) of these habitats effectively provide(s) for highly mobile habitat generalists. Fragmented forests did not support populations of Plethodon spp. at levels equal to that of intact forests. Large expanses of open grassland and shrub-pole habitats separate the 2 forested treatments; thus, fragmented forests might be functioning as sink habitats and their populations of Plethodon spp. could be at risk of local extinction. Reclaimed mine surfaces were probably too hot and dry to accommodate salamanders due to the openness of early successional reclaimed habitats and the removal of $O$ horizons, as organic matter improves the moistureholding capacity of soil. Additionally, removal of A horizons during mining reduces nesting sites and prey availability for salamanders because this horizon is where most invertebrates reside. Compaction of minesoils and their high rock fragment content may prohibit burrowing 
opportunities for salamanders. My study area supported a high diversity of amphibians. Mountaintop removal mining and its associated reclamation techniques may greatly limit distribution of salamanders and raise regional concerns about their population persistence.

\section{Introduction}

Great concern for potential worldwide amphibian declines arose in recent years (e.g., Pechmann et al. 1991; Blaustein et al. 1994). Possible causes of declines are often human-induced and include introduction of fishes (Bradford 1991), acidification (Beebee et al. 1990), habitat destruction (Blaustein and Wake 1990) and fragmentation (Wyman 1990), pollution, silvicultural practices, and general deforestation (Stebbins and Cohen 1995).

Effects of forest harvesting on herpetofauna has received considerable attention and serious detrimental effects of clearcutting on amphibian populations have been documented. Studies of salamanders or amphibians in general have found that clearcutting can reduce abundance (e.g., Petranka et al. 1993, 1994), biomass (Bury 1983; Enge and Marion 1986), density (e.g., Ash 1997), species richness, and rates/levels of detection or capture (deMaynadier and Hunter 1998). Clearcutting also can affect age structure of populations (Ash 1997; Sattler and Reichenbach 1998) and destroy salamander burrows, potentially affecting population persistence (Dodd 1991). However, several studies have documented or predicted recovery of post-clearcutting salamander populations in 15 years (Duguay and Wood 2002), 20-24 years (Ash 1997), and 50-70 years (Petranka et al. 1993).

Unlike amphibians, reptiles have been found to benefit from clearcutting. Reptile abundance and species richness can be higher in clearcuts than in unharvested stands (Adams et al. 1996; Perison et al. 1997). However, intensity of clearcutting and degree of site preparation appear to determine how reptile populations respond to clearcutting, but considerable betweentaxon differences occur (Enge and Marion 1986).

Mountaintop removal is defined as "a mining method in which the top of a mountain or ridge is flattened in the process of mining" (Barnhisel et al. 2000). With this large-scale surface mining technique, the overburden above a coal seam is excavated and temporarily set aside. 
Mountaintop removal mining is used in West Virginia, Virginia, Tennessee, Kentucky, and Pennsylvania in areas characterized by steep terrain and with large contiguous coal reserves that lie close enough to the surface to be economically mineable (United States Environmental Protection Agency 2000). This mining technique may impact herpetofauna in ways similar to clearcutting because forests also are removed with this disturbance; however, mountaintop removal mining may be even more harmful due to the size and magnitude of disturbance it creates. For example, on the 3 mountaintop removal mines in this study, reclaimed mine habitat totaled approximately 2000 ha on each mine (Table 1). In addition, the large-scale removal of soil involved with this mining process does not occur with clearcutting.

Overburden material becomes a mixture of topsoil and unconsolidated rock material upon its removal and subsequent replacement. Topsoil is not separately removed and then replaced on the surface of reclaimed mountaintop removal mines for a variety of reasons, including cost (Daniels and Stewart 2000). Because the geological strata become unconsolidated, they constitute a much greater volume than the once consolidated material (United States Environmental Protection Agency 2000). Therefore, not all overburden can be returned to the mountaintop; otherwise, long-term stability problems may stem from too steep of slopes (United States Environmental Protection Agency 2000). Hauling excess spoil to other sites is also too costly; therefore, it is deposited into valleys, creating a valley fill (United States Environmental Protection Agency 2000).

Although mountaintop removal mining has been implemented for over 30 years in West Virginia, the separate and synergistic effects of such large-scale disruption to soil, geologic, and hydrologic regimes have only recently come under investigation. The mountaintop removal mining technique has been litigated, in part due to adverse impacts on fish, wildlife, and the general environment (Vollers 1999). The United States Environmental Protection Agency (EPA) is currently conducting an environmental impact assessment of this mining technique, the draft of which was released May 29, 2003.

Disruption of terrestrial habitats caused by mountaintop removal mining may involve a permanent alteration in topography (Starnes and Gasper 1995). Terrestrial impacts include direct loss or fragmentation of habitat, as well as alterations in habitat structure and soil chemistry. Oliver and Larson (1996) characterize a severe disturbance as one where understory, forest floor and soil are removed; therefore, mountaintop removal mining is a severe disturbance. 
Herpetofauna can be valuable tools for investigating terrestrial impacts of mountaintop removal mining. Amphibians can function as important pollution indicators because their skin is porous and therefore, quickly reacts to changes in environmental quality (Blaustein and Wake 1990). Salamanders may be especially useful in documenting environmental changes due to their long lifespans and low fecundity (Droege et al. 1997). In many forest ecosystems, salamanders can be the most abundant vertebrates and are major contributors of biomass (Burton and Likens 1975). Some species can have densities up to ten animals $/ \mathrm{m}^{2}$ (Gergits and Jaeger, 1990). Reptiles are fairly resistant to environmental stresses that would adversely affect amphibians (e.g., droughts) and they maintain relatively high population numbers (Read 1992). Therefore, reptiles are better as indicators of non-climatic environmental changes (Read 1992) and provide a unique compliment to amphibians as study organisms. Herpetofauna serve as both predator of and prey to birds, mammals, fish, and other herpetofauna (Blaustein and Wake 1990) and they also feed upon invertebrates (Green and Pauley 1987); therefore, changes in their populations could potentially impact an entire ecosystem.

Few peer-reviewed, published scientific studies of herpetofaunal use of reclaimed coal surface mines or their use of areas bordering such mines have been conducted (Riley 1960; Myers and Klimstra 1963; Redmond 1980; Gore 1983; Middelkoop et al. 1998). To my knowledge, Myers and Klimstra (1963) are the only other investigators to publish research on terrestrial herpetofaunal use of areas disturbed by coal mining. Of these herpetofaunal studies, none were conducted in West Virginia or on reclaimed mountaintop removal mines.

I evaluated use of reclaimed mountaintop removal mine habitat for herpetofauna based on herpetofaunal species richness and abundance 1) among unmined native forested habitat and habitats on reclaimed mountaintop removal minesand 2) between on-mine reclaimed grassland and reclaimed shrub-pole habitats and structurally similar off-mine grassland and shrub-pole habitats that were created by other types of disturbance.

\section{Methods}

\section{Study Sites}

Study areas were located on and near 3 mountaintop removal mines in southwestern West Virginia: Hobet 21, Cannelton, and Dal-Tex. These mines were located in Boone, Kanawha and Fayette, and Logan counties, and in Mud River and Little Coal River, Twentymile Creek, and 
Spruce Fork watersheds, respectively. They had considerable distance between them (over a hundred miles between Dal-Tex and Cannelton Mines) to provide geographical perspective (Hall et al. 1978). Study sites were located within the Allegheny Plateau physiographic province, which is characterized by moderate to strong relief and contains central hardwood forests (Strausbaugh and Core 1977). Habitat types on the 3 mines included reclaimed grasslands, reclaimed shrub-pole, and forest fragments with reclaimed habitats covering 2431, 1819, and 2180 ha (Balcerzak and Wood 2003).

Early successional off-mine habitats structurally similar to reclaimed grassland and reclaimed shrub-pole habitats were located in southern West Virginia on Wildlife Management Areas (WMAs) and private property. Grassland and shrub-pole habitats generated from nonmining disturbance are rare in West Virginia; the only plots that I found in the study area that I was granted permission to access and that would be relatively undisturbed by humans were considerably smaller than the on-mine grassland and on-mine shrub-pole habitats. Fork Creek WMA, $1.6 \mathrm{~km}$ northeast of Nellis in Boone County, contained approximately 1 ha each of grassland and shrub-pole areas. Private property that I surveyed on Camp Creek Road is also in Boone County and was 1.28 ha. Mud River WMA is in Lincoln County, as was another private property that I surveyed; this private property abutted Mud River WMA. Total grassland area in Mud River WMA was 80 ha, and shrub-pole habitat only occurred in a few areas that were less than 1 ha each. The off-mine grassland sampling point on private property near Mud River WMA was 0.39 ha.

To compare herpetofaunal species richness and abundance among unmined habitats and habitats on reclaimed mountaintop removal mines, I sampled in 4 treatments: reclaimed grasslands, reclaimed shrub-pole habitats, fragmented forests (forests bordered on at least 3 sides by reclaimed mine habitat), and intact forests (forests not located on mine property and not directly impacted by mining activity). The latter treatment represented the natural landscape while the other treatments represented the disturbed landscape.

On Hobet 21, I placed sampling points in the following treatments: reclaimed grassland $(\mathrm{N}=1)$, reclaimed shrub-pole habitat $(\mathrm{N}=1)$, and fragmented forests $(\mathrm{N}=2$; Tables 1 and 2$)$. Just south of Hobet 21, I selected an intact forest sampling point. On DarTex, I installed 1 reclaimed grassland sampling point, and approximately $1.6 \mathrm{~km}$ east of this mine, 2 intact forest sampling points were located. In 2000 and most of 2001, there was only 1 intact forest sampling 
point near Dal Tex. In August of 2001, I installed another 1 in a particular hollow of this forest to provide baseline data in the event this area is mined with the mountaintop removal mining process. I sampled this additional point in September and October of 2001 and during all other sampling sessions throughout 2002.

Cannelton had sampling points in these treatments: reclaimed grassland $(\mathrm{N}=1)$, reclaimed shrub-pole $(\mathrm{N}=2)$, and fragmented forest $(\mathrm{N}=1$; Tables 1 and 2$)$. The intact forest treatment for Cannelton was located approximately 30 miles northeast of the mine, on the border of Clay and Nicholas counties.

To compare herpetofaunal species richness and abundance between early successional on-mine reclamation habitats and structurally similar off-mine habitats that were created by another type of disturbance, I sampled grasslands and shrub-pole habitats in 2 treatments: onmine (reclaimed) and off-mine. At Fork Creek WMA, I installed grassland ( $\mathrm{N}=1)$ and shrubpole $(\mathrm{N}=2)$ sampling points. At Mud River WMA and on private land bordering it, I installed grassland sampling points (1 in each location). On private property on Camp Creek Road, I established a shrub-pole sampling point. I collected all data for this component of the study in 2002.

Fragmented and intact forests contained 60-80 year-old, second-growth, mature hardwoods. Overstory species included tuliptree (Liriodendron tulipifera), red and sugar maples (Acer rubrum and A. saccharum), American sycamore (Plantanus occidentalis), northern red, white, and black oaks (Quercus rubra, Q. alba, and Q. velutina); pignut, bitternut, and shagbark hickories (Carya glabra, C. cordiformis, and C. ovata); American beech (Fagus grandifolia), white ash (Fraxinus americana), and black birch (Betula lenta; Chap 2). Understory species (seedlings, saplings, poles) included black gum (Nyssa sylvatica), flowering dogwood (Cornus florida), ironwood (Carpinus caroliniana), spicebush (Lindera benzoin), and other common hardwood species, including the aforementioned overstory species (Chap 2). Percent cover by forest in the counties of this study was: Boone (84\%), Kanawha (77\%), Logan (85\%), Fayette (85\%), Clay (87\%), and Nicholas (80\%; Griffith and Widmann, 2003).

Off-mine grasslands contained grasses and forbs. Predominant grasses included deertongue grass (Panicum clandestinum), tall fescue (Festuca arundinacea), orchard grass (Dactylis glomerata), and broom sedge (Bromus inermis; Ammer, 2003). Some species present in lower numbers included timothy (Phleum pratense) and smooth brome (Ammer, 2003). Forbs 
included birdsfoot-trefoil (Lotus corniculatus), alfalfa (Medicago sativa), aster (Aster spp.), and crownvetch (Coronilla varia; Ammer, 2003). These grasslands sometimes contained a few shrub-pole species, mostly sourwood (Oxydendrum arboreum), pawpaw (Asimina triloba), spicebush (Lindera benzoin), and bladdernut (Staphylea trifolia; Chap 2).

As with reclaimed shrub-pole habitats, off- mine shrub-pole habitat contained shrub, sapling, and pole-sized stems. Predominant shrub-pole species included autumn olive (Elaeagnus umbellata), multiflora rose (Rosa multiflora), blackberry and raspberry (Rubus spp.), pawpaw, spicebush, greenbrier (Smilax spp.), box elder (Acer negundo), and ironwood (Carpinus caroliniana; Chap 2).

\section{Reclaimed Habitat}

Reclaimed grasslands that I sampled ranged in age from 10-18 years post-reclamation (Table 1) and were in an arrested stage of succession. Because all of the understory, forest floor and soil were removed with mountaintop removal mining, this mining technique can be classified as a severe disturbance, such as those caused by landslides or glacier retreat (Oliver and Larson, 1996). Patterns of stand development that normally occur after disturbances in forests have not yet begun in these reclaimed grasslands. Forests in the central Appalachians are often dominated by tree regeneration within 5 years post-disturbance clearcuts and within 10 years, an overstory canopy of trees over 20 feet tall is common (Smith, 1977). Twenty years post-disturbance, reclaimed grasslands are not even dominated by tree regeneration.

Predominant grasses included tall fescue, orchard grass, broomsedge (Andropogon virginicus), perennial ryegrass (Lolium perenne), hair grass and redtop (Agrostis scabra and A. stolonifera), timothy, and smooth brome (Wood and Edwards, 2001). Forbs included birdsfoot trefoil, alfalfa, sericea and bicolor lespedezas (Lespedeza cuneata and L. bicolor), red clover (Trifolium pratense), golden rod (Solidago spp.), sweetclover (Melilotus spp.), aster, wild lettuce (Lactuca virosa), fleabane (Erigeron canadensis), plantain (Plantago spp.), crownvetch, and sedge (Carex spp.; Wood and Edwards, 2001). Grasslands sometimes contained a few shrub species, mostly planted autumn olive and multi-flora rose (Wood and Edwards, 2001).

Reclaimed shrub-pole habitats contained shrub, sapling, and pole-sized stems and were 18-28 years old (Table 1). I used vegetation to define reclaimed treatments because reclamation age of grassland and shrub-pole treatments overlapped. Predominant shrub-pole species in this treatment included autumn olive, multiflora rose, red maple, American sycamore, tuliptree, 
European black alder (Alnus glutinosa), blackberry and raspberry, sourwood, black locust (Robinia pseudoacacia), and scotch and white pines (Pinus sylvestris and P. strobus; Wood and Edwards, 2001). Many of the grass and forb species found in the grassland treatment also occurred in reclaimed shrub-pole habitats.

Soils

Native soils tended to be deep, well drained, steep (Van Houten et al., 1981; Wolf 1994), and had high percent cover by leaf litter. Thomas et al. (2000) sampled minesoils on Dal-Tex Mine and found average sola depth (combined thickness of A, AC, and Bw horizons) was $97 \mathrm{~cm}$ in native soils and all native soils sampled had $\mathrm{O}$ horizons. These authors did not analyze their results statistically and compared 3 native soil pits to 24 minesoil pits ( 6 pits for each of 4 age classes), but their study is the only one of its kind that I found.

On Dal-Tex Mine, Thomas et al. (2000) also observed young minesoils to show little to no profile development and a 23-year-old minesoil that showed some development of weak B horizons. Newly reclaimed minesoils have low organic matter content due to destruction of A horizons (Stephens et al., 2001), but A horizons of minesoils increase with time and even become deeper than native soils in as little as 7 years, according to Thomas et al. (2000), which they attributed to the seeding of grasses and legumes during reclamation. A horizons are the topmost mineral horizons and they contain some organic matter (Thomas et al., 2000). While O horizons (organic horizons above mineral soil) sometimes develop within minesoils 2 years of age, minesoils up to 11 years old may not have any (Thomas et al., 2000). Average sola depth ranged from $12 \mathrm{~cm}$ (2 year-old reclaimed) to $31 \mathrm{~cm}$ (23 year-old reclaimed) on reclaimed soils (Thomas et al., 2000). Surface rock fragment content of minesoils showed no pattern due to age of minesoil; 11-year-old minesoils had a higher content than 23-year-old minesoils, but 2-yearold rock fragment content was lower than that in 23-year-old minesoils (Thomas et al., 2000). Thomas et al. (2000) suspected that these differences were due to variability in blasting and reclamation techniques.

Native soils had an average water-stable aggregation of $63 \%$ in their surface horizons and $62 \%$ in their subsurface horizons, compared to $31-56 \%$ in surface horizons and $12-54 \%$ in subsurface horizons of minesoils ranging in age from 2 to 23 years. Aggregation is a measure of stability and "expresses the resistance of soil structural aggregates to breakdown when subjected to disruptive processes (Thomas et al., 2000). 


\section{Data Collection}

I constructed drift fence arrays with associated pitfall and funnel traps to sample for herpetofauna (Fig. 1). This is a useful method to capture large numbers of individuals (Campbell and Christman 1982), to capture individuals that might otherwise be missed (Bury and Corn 1987), and to compare relative abundance among a variety of habitat types (Campbell and Christman 1982).

Drift fences consisted of 30-cm tall, plastic silt fencing cut into $15-\mathrm{m}$ long sections and supported by wooden stakes (Enge 1997). The plus-shaped (+) fence design, chosen to intercept animals traveling from any direction (Campbell and Christman 1982), consisted of 4 15-m long “arms" (Vogt and Hine 1982) with 18.9-L plastic buckets at each end buried flush with the soil surface (Campbell and Christman 1982). Each array had a central separation of $15 \mathrm{~m}$ (Campbell and Christman 1982). I positioned funnel traps (minnow trap \#1275, Frabill, Jackson, Wisc.) in the middle on each side of every array arm (Campbell and Christman 1982). To prevent against amphibian dehydration, I wetted and placed sponges or paper towels in each pitfall and funnel trap (Daoust 1991). In addition, I provided shade to captured animals by placing cut silt fencing over the funnel traps and by elevating plastic bucket lids several inches over the pitfall openings with the use of untreated 2 x 4 lumber (Homyack 1999).

I opened all arrays for 4-12 trap nights in March and May-October 2000-2002 (with the exception of August, 2001 due to logistical constraints) and for 4 trap nights in February 2002, equaling 21 trapping sessions. I checked traps every other day in 2000 and 2001 when open (Vogt and Hine 1982; Brenner et al. 1992; Corn 1994). In 2002, I checked them every third day due to logistic constraints incurred from data collection for separate studies (Chaps 3 and 4). I identified captured individuals to species, marked them to identify recaptures, and then released animals at least $3 \mathrm{~m}$ from the drift fence array (Vogt and Hine 1982). I excluded recaptures from data summaries.

I measured habitat characteristics and vegetation in 2002 at each drift fence array sampling point using modified methods of James and Shugart (1970) and the Breeding Bird Research Database program (BBIRD; Martin et al. 1997). I used these methods because my study was part of a larger study that also sampled songbird populations (Wood and Edwards, 2001). I established vegetation subplots (each 0.04 ha) at each drift fence array sampling point at the center and $35 \mathrm{~m}$ away at $0^{\circ}, 120^{\circ}$, and $240^{\circ}$ (Fig. 2). Within each 0.04 ha subplot, I identified 
all tree species, measured their diameter at breast height (dbh), and categorized them into 1 of 2 dbh classes: $8-38 \mathrm{~cm}$ and $>38 \mathrm{~cm}$. I recorded the overall habitat type of each subplot: mature mixed forest (hardwoods and softwoods), mature hardwoods, shrub-pole, grassland, and ecotones (e.g., mature hardwoods/shrub-pole). I also established a 5.0-m radius circle at the center within each subplot, in which I recorded number of seedling, sapling, and pole stems $<8$ cm dbh.

I measured percent ground cover and percent canopy cover using an ocular sighting tube on each subplot (James and Shugart 1970) at every $2.26 \mathrm{~m}$ along each of the $411.3-\mathrm{m}$ transects that intersected in the subplot center (Fig. 2), totaling 20 measurements each. In all treatments, percent ground cover included green (grass, shrubs, fern, or herbaceous vegetation $<0.5 \mathrm{~m}$ in height), leaf litter, woody, bare ground/rock, moss, and water. I recorded percent canopy cover for 4 layer classes in each treatment based on height of vegetation: shrub (>0.5-3 m), sapling (3.1-6 m), understory (6.1-12 m), and overstory (>12 m). I visually estimated height of each layer class. Sums of each variable measured at $2.26 \mathrm{~m}$ transect locations were divided by 20 to provide quantitative measure of percent cover.

At grassland and shrub-pole treatments, I measured vegetative cover and grass height to the nearest dm using a Robel pole (Fig. 3) at the subplot center, and at 1, 3, and $5 \mathrm{~m}$ along each transect for a total of 16 measurements (Fig. 4; Robel et al. 1970). Four measurements were taken at each subplot center while facing the center from each transect direction. I also measured green height (forb and grass height) to the nearest $\mathrm{dm}$ using a measuring tape at the subplot center and at 1, 3, 5, and $10 \mathrm{~m}$ along each transect. I took maximum height measurements by choosing the tallest forb or grass within a 1-dm radius from the specified transect locations.

In all treatments, I measured organic litter depth to the nearest $\mathrm{cm}$ using a metric ruler. Depth was recorded at the subplot center and at 1,3, and $5 \mathrm{~m}$ along each transect, equaling 13 measurements. I determined distance to the closest edge type (paved road, open-canopy road, partially open-canopy road, agricultural opening, development, stream, clearcut, wildlife opening, natural gap, valley fill, grassland, forest, pond, or autumn olive block) by pacing from each subplot and measured average canopy height and percent slope using a clinometer and aspect with a compass. 


\section{Statistical Analysis}

Trapping periods differed in length and unequal trap effort resulted from theft of funnel traps, weather conditions rendering pitfall traps nonfunctional, funnel traps rolling away from drift fences, movement of funnel traps away from fences by humans or animals, obstruction of pitfall traps with plastic bucket lids used for shading due to interference by humans, fence collapse from treefall or destruction by humans. To account for these differences, I divided the sum of the number of animals captured in all pitfall and funnel traps at each array during a trapping period by the sum of the number of operable traps (maximum $=16$ operable traps per sampling point; 8 funnel traps and 8 pitfalls) for each night of the trapping session. I multiplied this value by 100 to obtain mean captures per treatment in 100 array-nights (Corn 1994).

Additionally, I adjusted the sum of the number of species per taxon using this procedure as well.

I used analysis of variance (ANOVA) to compare abundance and species richness of herpetofauna among treatments for drift fence array data. For the ANOVA models used in comparing species richness, dependent variables were mean richness of: 1) all herpetofauna, 2) amphibians, 3) reptiles, 2) salamanders, 3) toads and frogs, and 4) snakes. For the ANOVA models used in comparing abundance, dependent variables included those used for richness models as well as: 1) terrestrial salamanders (for undistubed and mining-disturbed analyses only), 2) plethodontids (for undistubed and mining-disturbed analyses only), 3) bufonids, 4) ranids, 5) snakes, 6) colubrids, and 7) individual species with 30 captures. For the undistubed and mining-disturbed component of this study, independent variables for ANOVAs were treatment, sampling point (within treatment by mine), year, and the interaction between treatment and year; I blocked for mine. I used sampling point (within treatment by mine) as an error term to test for effects of treatments. Because I used year as an independent variable and the new intact forest point was not sampled in 2000 and was only sampled in 2 of the 7 trapping sessions in 2001, all ANOVA tests excluded data from this point. However, comparison of expected and observed species included data from this sampling point and I reported them as incidental captures (Appendix 1). For the on- and off-mine grassland and shrub-pole component of this study, I tested for the main effects of treatment (on- and off-mine). The ANOVA model also accounted for effects due to habitat (grassland and shrub-pole habitats), sampling period, sampling point (within treatment by habitat), and the interactions between treatment and habitat, 
sampling period and treatment, sampling period and habitat, and sampling period, habitat, and treatment. I used sampling point (within treatment by habitat) as the error term to test for effects of treatments, habitats, and the treatment by habitat interaction.

I analyzed some herpetofaunal families, genera, and species separately because each one possesses unique traits that place differing habitat constraints on them. For example, toads from the family Bufonidae have dry, warty skin enabling the $\mathrm{m}$ to be largely terrestrial (Green and Pauley 1987), whereas frogs from the family Ranidae have moist skin and some species from this family require permanent water even after the breeding season. Additionally, by analyzing bufonids, I was able to include all captures recorded as Bufo spp. that exhibited traits of both Eastern American Toads (Bufo a. americanus) and Fowler's Toads (B. fowleri). These 2 species are capable of hybridizing (Conant and Collins 1998). Even within families, life histories can be quite different. All salamanders from family Plethodontidae are lungless; their skin must remain moist to maintain cutaneous respiration (Stebbins and Cohen 1995). The Plethodontini tribe (Petranka 1998) in this family includes species that are obligate terrestrial; they lack an aquatic larval stage (i.e., young appear as smaller versions of adults). They must replace water loss by retreating to moist environments rather than rehydrating in water like other plethodontids; otherwise, their tissues would become bloated (Stebbins and Cohen 1995). Finally, although Red Efts and Red-spotted Newts (Notophthalmus v. viridescens) are the same species, they represent different life stages (juvenile terrestrial and adult aquatic, respectively). Because the inclusion of aquatic adult data may have skewed the results of the terrestrial juvenile data, I conducted an analysis on Red Efts only (adults excluded).

To compare vegetative characteristics among treatments, I used ANOVA. Each of the habitat variables served as dependent variables and treatment was the independent variable. In these models, I also blocked for mine. I used arcsine-square root transformation for all percentage variables $\left(\right.$ Zar 1999) and $\mathrm{A}^{\prime}=(\operatorname{COS}(45-\mathrm{A})+1)$ for slope aspects (Beers et al. 1966); $\mathrm{A}^{\prime}$ is the transformation index and $\mathrm{A}$ is the direction the slope faces in degrees. This slope transformation gives northeastern facing slopes a value of 2 , reflecting mesic conditions, while southwestern exposures receive a value of 0 and reflect xeric conditions.

I used Waller-Duncan k-ratio t-tests to compare means among treatments when $\mathrm{F}$ tests from ANOVA found significant differences among treatments. I analyzed data using Statistical Analysis System 8.1 (SAS Institute 2000) at an alpha level of 0.10. Use of a higher alpha level is 
justified when researching conservation issues to avoid making a type II error (Askins et al. 1990; Caughley and Gunn 1995). Because ANOVA is robust to deviations from normality and homogeneity of variance, I did not test these assumptions (Cody and Smith 1997; Zar 1999).

\section{Results}

\section{Unmined Habitat and Habitat on Reclaimed Mountaintop Removal Mines}

During 2000-2002, I captured 963 individuals and 31 species in drift fence arrays (Table 3), although 43 total species were encountered on the study areas through various methods (Appendix 1). Array captures included 10 salamander species, 8 toad and frog species, 3 lizard species, 9 snake species, and 1 turtle species. I captured 178 salamanders and 593 toads and frogs, equaling 771 amphibians. Of the 192 reptiles captured, 18 were lizards, 171 were snakes, and 3 were turtles.

Overall abundance $(\mathrm{F}=0.58, \mathrm{df}=3, P=0.65)$ and species richness $(\mathrm{F}=1.41, \mathrm{df}=3, P=0.33)$ of herpetofauna did not differ among the 4 treatments (Table 4). Amphibian abundance ( $\mathrm{F}=0.63$, $\mathrm{df}=3, P=0.62)$ and species richness $(\mathrm{F}=2.86, \mathrm{df}=3, P=0.13)$ also were not different among treatments. However, reptile abundance $(\mathrm{F}=4.10, \mathrm{df}=3, P=0.07)$ and species richness differed among treatments $(\mathrm{F}=3.60, \mathrm{df}=3, P=0.09)$; they were higher in reclaimed shrub-pole treatments than in both forested treatments.

Salamander abundance $(\mathrm{F}=3.48, \mathrm{df}=3, P=0.09)$ and species richness $(\mathrm{F}=6.99, \mathrm{df}=3$, $P=0.02$ ) were significantly different across treatments (Table 4). Both were higher in forested treatments. This taxonomic group comprised $23-33 \%$ of captures in forested treatments and 8$13 \%$ in grassland and shrub-pole treatments (Table 5). Red Efts were the most abundant salamanders (52\% of captures) and were the only salamander species found at every sampling point (Table 3). Red Efts have rough, granular skin (Green and Pauley 1987) and are tolerant of warm, dry conditions (Pough 1974). Therefore, it may be less sensitive to disturbance than other salamander species. Excluding this species from analyses of salamander abundance demonstrated an even stronger treatment effect on salamanders $(\mathrm{F}=5.98, \mathrm{df}=3, P=0.03)$. Both forested treatments contained more salamanders than reclaimed grasslands; intact forests also had a higher abundance than reclaimed shrub-pole treatments. Red Efts were 2 of 6 herpetofaunal species that had 30 captures; their abundance did not differ among treatments $(\mathrm{N}=92 ; \mathrm{F}=0.42, \mathrm{df}=3, P=0.74 ;$ Table 4$)$. 
Red Efts and Spotted Salamanders (Ambystoma maculatum) were the only salamander species found in every treatment (Table 4). Of the other salamander species encountered, 3 were in reclaimed habitats: 2 of 18 Northern Slimy Salamanders (Plethodon glutinosus) captured were in reclaimed shrub-pole treatments, while 1 of 2 Four-toed Salamanders (Hemidactylium scutatum) captured was in a reclaimed grassland treatment. I also observed 1 incidental Eastern Red-backed Salamander (Plethodon cinereus) in a reclaimed grassland.

Salamanders of the family Plethodontidae differed in abundance among treatments ( $\mathrm{F}=5.55, \mathrm{df}=3, P=0.04$ ); intact forests contained more than reclaimed treatments (Table 4). For Plethodon spp., I found differences in abundance among treatments ( $\mathrm{F}=5.56, \mathrm{df}=3, P=0.04)$; abundance was higher in intact forest than in any other treatment.

Toads and frogs did not differ in abundance $(\mathrm{F}=0.59, \mathrm{df}=3, P=0.64)$ or species richness $(\mathrm{F}=0.73, \mathrm{df}=3, P=0.57)$ among treatments (Table 4$)$. This taxonomic group was consistently present in the highest numbers in each treatment, comprising 51-64\% of all individuals captured (Table 5). Eastern American Toads and Northern Green Frogs (Rana clamitans melanota) were the only anuran species captured at every sampling point (Table 3). I encountered these and 4 other anuran species in every treatment: American Bullfrogs (Rana catesbeiana), Northern Leopard Frogs (Rana pipiens), Northern Spring Peepers (Pseudacris c. crucifer), and Pickerel Frogs (Rana palustris; Table 4). Northern Green Frogs ( $\mathrm{N}=190)$ and Pickerel Frogs ( $\mathrm{N}=192)$ were the most abundant species in this study (Table 3), each specie s contributed 19\% of all captures. Abundances of Eastern American Toads ( $\mathrm{N}=115 ; \mathrm{F}=1.23$, $\mathrm{df}=3, P=0.38)$, Northern Green Frogs (N=187; F=2.25, df=3, $P=0.18)$, and Pickerel Frogs $(\mathrm{N}=191 ; \mathrm{F}=1.07, \mathrm{df}=3, P=0.43)$ did not differ among treatments (Table 4 ). There were no differences in abundance among treatments for bufonids $(\mathrm{N}=147 ; \mathrm{F}=1.39, \mathrm{df}=3, P=0.33)$ or ranids $(\mathrm{N}=438 ; \mathrm{F}=1.94, \mathrm{df}=3$, $P=0.22)$.

Snakes differed in abundance $(\mathrm{F}=4.12, \mathrm{df}=3, P=0.07)$ and species richness $(\mathrm{F}=3.62, \mathrm{df}=3$, $P=0.08$ ); both were higher in reclaimed shrub-pole treatments than in forested treatments (Table 4). Snakes varied from $20-27 \%$ of captures in reclaimed treatments, while in the forested treatments, they made up 10-13\% of captures (Table 5). Of 9 snake species captured in arrays, 4 were present in all 4 treatments: Eastern Ratsnake (Elaphe alleghaniensis), Eastern Gartersnake (Thamnophis s. sirtalis), Eastern Milksnake (Lampropeltis t. triangulum), and Northern Copperhead (Agkistrodon contortrix mokasen; Table 3 ). There were no snake species captured 
at all 12 sampling points (Table 3). Eastern Gartersnake abundance $(\mathrm{N}=38 ; \mathrm{F}=0.36, \mathrm{df}=3$, $P=0.78)$ did not differ among treatments. Northern Black Racers were more abundant in the shrub-pole than grassland treatment $(\mathrm{N}=56 ; \mathrm{F}=8.97, \mathrm{df}=3, P=0.01)$; they were not captured in forested treatments (Table 4). For snakes of the family Colubridae, I found significant differences in abundance among treatments $(\mathrm{N}=142 ; \mathrm{F}=3.73$, $\mathrm{df}=3, P=0.08)$ with higher abundance in reclaimed shrub-pole than in forested treatments. This ANOVA excluded only Northern Copperheads ( $\mathrm{N}=29$; Table 3); they were the only snake species captured that were from another family (F. Viperidae).

I did not capture lizards in sufficient abundance to conduct statistical analyses; they made up only 1-3\% of total herpetofauna captured in each treatment (Table 5). Three of the 5 lizard species expected to occur in my study area were captured in drift fence arrays (Appendix 1); they included Eastern Fence Lizards (Sceloporus undulatus), Common Five-lined Skinks (Eumeces fasciatus), and Little Brown Skinks (Scincella lateralis) (Table 3). While I only captured 6 Eastern Fence Lizards in 2 treatments (Table 3), I observed them in every treatment (Appendix 1). They were rare in intact forests but common in all other treatments.

I did not capture turtles in sufficient abundance to conduct statistical analyses. I captured only 1 species of turtle in array traps, the Eastern Box Turtle (Terrapene c. carolina; Table 3), although I observed it in every treatment (Appendix 1). Turtles comprised $<1 \%$ of total captures in each treatment (Table 5). I documented occurrences of 2 other turtle species on mine property (Eastern Snapping Turtle [Chelydra s. serpentina] and Eastern Spiny Softshell Turtle [Apalone s. spinifera]; Appendix 1); none were in intact forests.

All categories of stem densities differed among treatments (Table 6). There were more stems $<8 \mathrm{~cm}$ in diameter in reclaimed shrub-pole and intact forests than in fragmented forests and reclaimed grasslands. Density of trees $8-38 \mathrm{~cm}$ dbh was less in reclaimed grasslands than in the other 3 treatments. Tree density $>38 \mathrm{~cm}$ was greater in fragmented forests than in all other treatments.

Ground cover differed most often between forested and reclaimed treatments. Bare ground / rock cover was higher in intact forests than in reclaimed treatments (Table 6). Leaf litter cover was lower in reclaimed grasslands than all other treatments. Conversely, green cover was highest in reclaimed grasslands. Woody debris cover was higher in intact forests than in the 
reclaimed treatments. Percent lespedeza was greater in reclaimed treatments and did not occur in forested treatments.

Grasslands had the lowest canopy cover by shrubs (>0.5-3 m) and saplings (>3-6 m) (Table 6). Cover from understory (>6-12 m) and overstory (>12 m) vegetation in forested treatments exceeded that in reclaimed treatments, as did canopy height. Other habitat variables measured were not different among treatments.

\section{Early Successional On- and Off-mine Treatments}

Overall herpetofuanal abundance $(\mathrm{F}=0.80, \mathrm{df}=1, P=0.40)$ and species richness $(\mathrm{F}=1.52, \mathrm{df}=1$, $P=0.25)$ did not differ between on-mine and off-mine treatments (Table 7). Although eleven herpetofaunal species were captured only in off-mine treatments compared to 4 captured only in on-mine treatments, the overall number of species captured was similar (17 species on mines; 24 species off mines).

Amphibian abundance $(\mathrm{F}=0.59, \mathrm{df}=1, P=0.47)$ and species richness $(\mathrm{F}=0.72, \mathrm{df}=1$, $P=0.42)$ and salamander abundance $(\mathrm{F}=0.89, \mathrm{df}=1, P=0.37)$ did not differ between on- and offmine treatments (Table 7). Although 7 salamander species were captured off mines and only 3 on mines, species richness $(\mathrm{F}=0.00, \mathrm{df}=1, P=0.98)$ did not differ between treatments. I found the highest proportion of salamanders in on-mine grasslands (28\%) and the lowest in on-mine shrubpole habitats ( $8 \%)$; they constituted about $14 \%$ of captures in each off-mine habitat. Red Efts were the most abundant salamander species $(\mathrm{N}=26 ; 73 \%$ of salamander captures $)$ and were the only salamander species that I found in both grasslands and shrub-pole habitats, on- and offmines (Table 9). I captured 5 salamander species at off-mine treatments only (but I found only 1 individual for 3 of these species), compared to 1 salamander species found only at on-mines treatments. Two of these 5 species, the Cumberland Plateau Salamander (Plethodon kentucki) and the Northern Red Salamander (Pseudotriton r. ruber), were never observed on reclaimed treatments, even when including data from the first 2 years of study from the pre- and postmining treatment comparison (Appendix 1) and from a separate study in which I examined effects of reclaimed mine edge on salamanders (Chap 4).

Toad and frog abundance $(\mathrm{F}=0.23, \mathrm{df}=1, P=0.64)$ and species richness $(\mathrm{F}=1.20, \mathrm{df}=1$, $P=0.30$ ) were not different on- or off- mines (Table 7). This taxonomic group was consistently present in the highest numbers in each habitat on- and off-mines, comprising $43-68 \%$ of total 
captures (Table 8). Cope's Gray Treefrogs (Hyla chrysoscelis) were restricted to on- mine shrubpole habitats, and Wood Frogs (Rana sylvatica) to off-mine treatments (Table 9). Eastern American Toads ( $\mathrm{N}=37 ; 25 \%$ of all anuran captures) and Pickerel Frogs ( $\mathrm{N}=36 ; 24 \%$ of all anuran captures) were the most abundant species in this study. Abundance of toads in the family Bufonidae $(\mathrm{F}=0.82, \mathrm{df}=1, P=0.39)$ and abundance of Eastern American Toads $(\mathrm{F}=0.35, \mathrm{df}=1$, $P=0.57$ ) did not differ between on- and off-mine treatments (Table 7). Similarly, abundance of frogs from the family Ranidae $(\mathrm{F}=2.99, \mathrm{df}=1, P=0.12)$ and abundance of Pickerel Frogs $(\mathrm{F}=1.20$, $\mathrm{df}=1, P=0.31)$ did not differ between treatments either.

Reptile abundance $(\mathrm{F}=1.44, \mathrm{df}=1, P=0.26)$ did not differ between treatments, but species richness $(\mathrm{F}=3.98, \mathrm{df}=1, P=0.08)$ was higher on- than off-mines (Table 7). Likewise, snake abundance $(\mathrm{F}=2.40, \mathrm{df}=1, P=0.16)$ was not different due to treatment, but species richness $(\mathrm{F}=4.65, \mathrm{df}=1, P=0.06)$ was higher on-mines. Off- mine grasslands contained the highest proportion of snakes $(32 \%)$, while in other on-mine and off-mine habitats, they constituted around $24 \%$ of captures (Table 8). Of the 6 snake species captured, 3 were present in grasslands and shrub-pole habitats both on- and off-mine: Eastern Gartersnake, Eastern Milksnake, and Northern Copperhead (Table 9). I encountered Eastern Hog-nosed Snakes (Heterodon platirhinos) (Table 9) and only 1 incidental observation of an Eastern Ratsnake only at on- mine treatments (Appendix 1). I captured only 1 Northern Ring-necked Snake (Diadophis punctatus edwardsii) at an off-mine grassland and 1 Common Ribbonsnake (Thamnophis s. sauritus) at an off-mine shrub-pole sampling point. For snakes of the family Colubridae, I found no differences in abundance between on- and off-mine treatments $(\mathrm{F}=1.83, \mathrm{df}=1, P=0.18)$.

Lizards were not captured in high enough abundance to conduct statistical analyses; they made up only $0-5 \%$ of total herpetofauna captured in each treatment, both on- and off- mines (Table 8). The only turtle species that I found was the Eastern Box Turtle, and it was present both on- and off-mines (Appendix 1).

On mines, there was lower percent cover of bare ground / $\operatorname{rock}(\mathrm{F}=3.51, \mathrm{df}=1, P=0.10)$ and leaf litter $(\mathrm{F}=5.70, \mathrm{df}=1, P=0.04)$, as well as less canopy cover by trees in the following height classes: $0.5-3 \mathrm{~m}(\mathrm{~F}=9.25, \mathrm{df}=1, P=0.02),>6-12 \mathrm{~m}(\mathrm{~F}=28.91, \mathrm{df}=1, P=0.0007)$ and $>12 \mathrm{~m}$ $(\mathrm{F}=46.52, \mathrm{df}=1, P=0.0001$; Table 10$)$. Canopy height $(\mathrm{F}=8.53, \mathrm{df}=1, P=0.03)$ and densities of trees $>38 \mathrm{~cm}$ dbh $(\mathrm{F}=9.80, \mathrm{df}=1, P=0.01)$ also were less on mines than off mines. On mines, distance to nearest edge was greater $(\mathrm{F}=21.11, \mathrm{df}=1, P=0.002)$, organic litter was deeper 
$(\mathrm{F}=5.92, \mathrm{df}=1, P=0.04)$, percent cover by lespedeza was higher $(\mathrm{F}=17.99, \mathrm{df}=1, P=0.003)$, and elevation was lower $(\mathrm{F}=49.84, \mathrm{df}=1, P=0.09)$ than off mines.

Treatment and habitat interacted significantly for densities of stems $<8 \mathrm{~cm} \mathrm{dbh}(\mathrm{F}=4.42$, $\mathrm{df}=1, P=0.07)$ and for canopy cover by trees $>3-6 \mathrm{~m}$ tall $(\mathrm{F}=4.48, \mathrm{df}=1, P=0.07$; Table 10$)$. Comparing habitats separately, stem densities $<8 \mathrm{~cm}$ diameter did not differ for on- vs off-mine grasslands $(\mathrm{F}=2.19, \mathrm{df}=1, P=0.21)$ nor for shrub-pole habitats $(\mathrm{F}=2.57, \mathrm{df}=1, P=0.18)$. Off-mine canopy cover by trees $>3-6 \mathrm{~m}$ tall was greater than on-mine in grasslands $(\mathrm{F}=30.62, \mathrm{df}=1$, $P=0.005)$, but did not differ between on- and off-mine shrub-pole $(\mathrm{F}=0.84, \mathrm{df}=1, P=0.41)$. No other habitat variables were significantly different between on- and off-mine treatments.

\section{Discussion}

\section{Unmined Habitat and Habitat on Reclaimed Mountaintop Removal Mines}

Given the differences in physiological limiting factors between amphibians and reptiles (e.g., most amphibians desiccate in dry environments (Zug et al. 2001) but the dry scaly skin of reptiles effectively resists water loss (Green and Pauley 1987), it is not surprising that overall herpetofaunal abundance and richness did not differ among habitats. Reptile abundance tended to increase from forests to grasslands, while the reverse was true of amphibians. Thus, combining these 2 distantly related taxa may have obscured taxon-specific differences among habitat treatments. Pais et al. (1988) conducted a study in eastern Kentucky, where the herpetofaunal community is similar to that on my study sites. Using similar techniques (drift fences in conjunction with pitfalls and funnel traps), they also found no differences in total captures of herpetofauna among structurally dissimilar habitats: clearcuts, mature forest, and wildlife clearings. However, they found reduced herpetofaunal richness in mature forest than in clearcuts and wildlife clearings and were uncertain whether species richness was related to distance to water, nonwoody plant biomass, or both factors.

Within amphibians, generalist anurans were more evenly distributed across habitats than

salamander species, most of which have narrow habitat requirements (Conant and Collins 1998). Anurans constituted the majority of amphibian captures ( $77 \%)$, which may explain why I found no differences in amphibian abundance among treatments.

As expected, mountaintop removal mining and its associated reclamation appear to adversely affect salamanders. These impacts are shown in reduced abundance of salamanders in 
reclaimed treatments. Not only was there a direct loss of salamander populations with soil excavation associated with mining activities, but also a reduced carrying capacity in the reclaimed landscape due to habitat conversion from forests to grasslands and shrub-pole habitats.

Species found in reclaimed treatments that are not typically found in grassland and shrubpole habitats may have been traversing or using these habitats during seasonal migrations (e.g., Spotted Salamanders) or because they were excluded from forested habitats by territorial conspecifics (e.g., Eastern Red-backed Salamanders; deMaynadier and Hunter 1998). Proximity of some sampling points to forested habitats or other sources of moist substrates may have contributed to infrequent instances of salamander captures in non-forested treatments (e.g., a Northern Slimy Salamander at a particularly wet shrub-pole point).

Intact forests had higher abundance of terrestrial salamanders (genus Plethodon) and salamanders from the family Plethodontidae than reclaimed treatments. As $80 \%$ of plethodontids captured in this study were in the genus Plethodon, I expected similar patterns of abundance for these 2 groups among treatments. Terrestrial salamanders are greatly constrained by moisture due to their habitat requirements (Stebbins and Cohen 1995). Thus, I anticipated higher abundances in the relatively cool, moist forested treatments as opposed to the drier shrub and grassland treatments. Additionally, fragmented forests on reclaimed mines may be less suitable than intact forests for terrestrial salamanders in the genus Plethodon based on differences in abundance between these forested treatments. Because salamanders in general are limited in dispersal abilities, populations in the smaller forest patches of fragmented forests are vulnerable to local extinction events (Waldick 1997).

Sources on the distribution of herpetofauna of the region (Behler and King 1995; Conant and Collins 1998) describe Notophthalmus v. viridescens as being limited to forested areas. Similarly, other studies have found it to be sensitive to forest fragmentation (Gibbs 1998a) and forest edge (Gibbs 1998b) and Pais et al. (1988) found this species to be associated with forest canopy. However, as mentioned previously, Red-spotted Newts also were found to be tolerant of warm and dry conditions (Pough 1974; Pais et al. 1988) and have been observed in a wide variety of conditions (Pais et al. 1988), which may explain why its abundance levels were similar among treatments in my study. Similarly, deMaynadier and Hunter (1998) did not find differences in abundance of this species among even-aged silvicultural treatments (clearcuts and conifer plantations) and reference forests. 
Several habitat features in the forested treatments favor habitation by salamanders, including more trees in larger dbh classes $(>8 \mathrm{~cm})$ and greater canopy cover from saplings, understory, and overstory when compared to 1 or both reclaimed treatments. Microclimate features important to salamanders may be less suitable after tree removal because humidity and soil moisture frequently decrease and soil temperature increases (Waldick 1997), which increases the possibility of salamander desiccation. Waldick (1997) reported that quality of leaf litter could decrease with conversion of forested habitat to early successional habitats; it often becomes drier. Therefore, although cover by leaf litter did not differ between reclaimed shrubpole treatments and forested treatments, the quality may have. Furthermore, reclaimed grasslands had lower leaf litter cover than all other treatments. Leaf litter is important for salamanders because it harbors prey items (deMaynadier and Hunter 1995) and provides refuge from hot and dry conditions (Bury 1983). Woody cover also was higher in intact forests than in reclaimed treatments. Both woody cover and leaf litter provide sites for salamander species to deposit eggs and are habitat features with which salamanders frequently associate (Green and Pauley 1987).

Although bare ground / rock cover was higher in forested treatments than in reclaimed treatments, other benefits associated with the closed canopy environments of forests (e.g., percent cover by leaf litter) appear to offset this trait and make these habitats superior for salamanders. Although not directly measured, it can be assumed that quality of bare ground in forested treatments differed from that in reclaimed treatments. As mentioned previously, reclaimed mine surfaces often contain unweathered rock material (Sencindiver and Ammons, 2000). Additionally, minesoils must be greatly compacted to combat erosion (Richards et al. 1993). Soil compaction reduces soil pore space and minesoils often lack organic matter; both of these traits contribute to increased minesoil dryness. The majority of salamanders reside below the surface (only 2-32\% of populations are found within leaf litter; Taub 1961) in efforts to avoid desiccation (Stebbins and Cohen 1995). Reclamation reduces ease of burrowing for salamanders, making minesoils less hospitable for them.

High site fidelity, small home ranges, physiological limitations, low fecundity, and inability to quickly traverse large distances make salamanders especially susceptible to effects of forest alterations (Pough et al. 1987; Petranka et al. 1993; Blaustein et al. 1994; Gibbs 1998b). Because salamanders share many characteristics of other taxa that are long-lived species (e.g., 
low fecundity; Droege et al. 1997), their vulnerability to habitat disturbances increases while chances of population recovery decrease (Congdon et al. 1993, 1994).

In a review of 18 studies of amphibian responses to clearcutting, deMaynadier and Hunter (1995) found that amphibian abundance was 3.5 times higher in unharvested stands than in recent clearcuts. While Ash (1997) observed an initial decrease in salamander abundance following clearcutting, he found that within 4-6 years, salamanders returned to clearcuts and he predicted that within 20-24 years post-cutting, population levels would recover and possibly flourish. Duguay and Wood (2002) found that salamander abundance did not differ in 15-yearold clearcuts and mature second-growth forest. They also observed 4 salamander species in clearcuts that did not occur in second-growth forests; however, only 1-4 individuals were captured for 3 of these 4 species. Eastern Red-backed Salamanders were the most common captures in each treatment of their study. In contrast, Petranka et al. (1993) estimated that it would take 50-70 years for populations to recover after clearcutting. Because mining results in greater soil disturbance than clearcutting, salamander populations may take longer to recover on reclaimed sites than the time frames reported in these studies. Based on ages of the reclaimed sampling areas (10-28 years post-disturbance) used in my study (Table 1), populations on reclaimed mountaintop removal mines have not yet reached abundance and species richness levels observed in intact forests.

Unlike salamanders, reptiles in general and snakes in particular used reclaimed shrubpole habitat more often than forested habitat. Snakes from the family Colubridae made up 83\% of snake captures and snakes constituted $89 \%$ of reptile captures. Therefore, it was not surprising that similar patterns of abundance occurred among these groups. Other authors found higher species richness (Adams et al. 1996) and greater abundance of reptiles (Phelps and Lancia 1995; Perison et al. 1997) in harvested stands than in control stands.

Although 8 of 9 snake species that I captured can occur in a variety of habitats, an equal distribution of snakes among treatments should not necessarily be expected. For example, Ross et al. (2000) found snake abundance and species richness to be inversely related to tree basal area when they compared mature forest stands with stands logged 2-10 years prior to their research. Two ubiquitous snake species (Eastern Gartersnake and Northern Ring-necked Snake) made up $84 \%$ of their captures and likely drove the results of their study. Similarly, 2 ubiquitous snake 
species made up 55\% of captures in my study (Northern Black Racers and Eastern Gartersnakes).

In another study, Florida Kingsnakes (Lampropeltis getula floridana) benefited from conversion of its native habitat (cypress ponds, savannah pine lands, and prairies) to sugarcane fields via increased prey density and provision of additional shelter for snakes in the limestone dredge material along banks of irrigation canals (Pough et al. 2001). Perhaps creation of riprap channels and rock chimneys in reclaimed habitat has served snake populations on mountaintop removal mines in a similar way. Evidence for increased prey on reclaimed treatments is provided by Chamblin (2002), who conducted surveys for small mammals at the same array locations used for this study. He found a higher abundance of Peromyscus spp. (the most abundant species he captured) in reclaimed treatments, along with higher abundance levels of the House Mouse (Mus musculus), Southern Bog Lemmings (Synaptomus cooperi), and Masked Shrews (Sorex cinereus). Northern Black Racers are opportunistic feeders (Green and Pauley 1987); this abundance of Peromyscus spp. and other small mammal species in reclaimed treatments may have provided incentive for this racer species to use these habitats more often. Additionally, snakes may be attracted to reclaimed habitats because they can reach their activity ranges faster and maintain them longer in the openness of reclaimed areas (Perison et al. 1997).

Several anurans species (Cope's Gray Treefrogs, Northern Green Frogs, Northern Spring Peepers, Eastern American Toads, and Wood Frogs) that I captured readily move into disturbed areas (T. K. Pauley, Professor of Herpetology at Marshall University, personal communication). That so many function as pioneer species may help explain why anuran abundance and species richness levels did not differ among treatments. Toads and frogs are more tolerant of temperature extremes than salamanders (Stebbins and Cohen 1995), and thus can subsist in nonforested habitats. The species for which I was able to conduct individual abundance analyses, Eastern American Toads, Northern Green Frogs, and Pickerel Frogs, are all ubiquitous. Thus, it was not surprising that they did not differ in abundance among treatments. However, Pais et al. (1988) found Eastern American Toads to be associated with dense herbaceous cover in wildlife clearings and Ross et al. (2000) found toad and frog richness to have a positive relationship with increases in tree basal area and also observed a positive association between Rana spp. and woody debris within stands. The only anurans restricted to forested habitats were Wood Frogs, as was expected considering their as sociation with moist, deciduous forests and preference for 
well-developed leaf litter (Green and Pauley 1987). My sampling methods may not have effectively sampled some species, such as treefrogs, which are sometimes sampled using plastic pipes driven into the ground (Perison et al. 1997). Cope's Gray Treefrogs were found only in reclaimed shrub-pole treatments and all individuals were captured at the same sampling point, which was adjacent to a wetland. This treefrog species is often associated with open woodlands (Green and Pauley 1987) and frequently uses shrubs as well as trees (Conant and Collins 1998), so their presence in this treatment was not surprising.

The Eastern Box Turtle was the only turtle species captured during my study, although other species were observed within the study areas. Eastern Box Turtles may have a natural wariness of pitfall traps and are too large to fit through the entrance of funnel traps used in this study (Pais et al. 1988). Thus, drift fence arrays were likely not effective means of sampling this and other turtle species. Reclaimed mine sites may not have provided appropriate habitat for this species because they are sensitive to litter and soil disturbances and prefer forests during the heat of the day and during cold times of the year for refuge and overwintering sites, respectively (Dodd 2001). Because Eastern Box Turtles create depressions in which to spend the night, escape heat, and overwinter, soil friability is important and increases opportunities for concealment (Dodd 2001). I commonly sighted this turtle species as an incidental and found it in every treatment. However, of the individuals found in traps $(\mathrm{N}=3)$ and sighted as incidentals $(\mathrm{N}$ $=41$ ), only 3 were found in reclaimed grasslands and 3 in reclaimed shrub-pole habitat. Twentythree Eastern Box Turtles were in intact forests and 15 were in fragmented forests.

While lizards were not captured in high enough abundances to allow statistical analyses, casual observations of species on study sites as well as known natural history characteristics of these species permits some speculation regarding the effects of mountaintop removal mining on them. Eastern Fence Lizards were captured in low numbers in arrays, but were commonly observed in reclaimed mine treatments. This lizard occupies dry, steep forests (Green and Pauley 1987), open woodlands, and grasslands (Behler and King 1995; Table 4). Therefore, aside from the direct loss of individuals during overburden removal, the large-scale habitat conversion due to mountaintop removal mining most likely has not negatively affected this species. I found Common Five-lined Skinks at every intact forest point; it typically prefers humid or damp environments in forests or cutover woods that are sufficiently supplied with stumps, snags, and logs (Green and Pauley 1987; Behler and King 1995; Conant and Collins 
1998). Reclaimed mine treatments probably did not provide favorable conditions for this species.

A key finding involved the significant impacts on salamander abundance and species richness due to mountaintop removal mining, which is likely influenced by both forest removal and soil disturbance associated with this mining method. It appeared that forest patches on these mine sites were not sufficient to support Plethodon salamanders at levels equal to those in intact forests, suggesting that these reclaimed grasslands and reclaimed shrub-pole treatments may function as sink habitats. Another notable result to this component of the study is that reclaimed grasslands never contained the highest abundance or richness of any class, order, family, genus, or species of herpetofauna. The only species with higher abundance in reclaimed grasslands as compared to other treatments was the Northern Black Racer, but even abundance of this species was lower in reclaimed grasslands than in reclaimed shrub-pole habitats.

\section{Early Successional On- and Off-mine Treatments}

Herpetofaunal populations in off-mine and on-mine treatments only differed in species richness; species richness was greater off mines for both reptiles and snakes. Additionally, few vegetative characteristics differed between on- and off-mine treatments.

Off-mine sampling points were always adjacent to large tracts of contiguous intact forests; off-mine grassland and off-mine shrub-pole patches were small. The close proximity of intact forests to off-mine sampling points may help explain the reduced snake species richness in off-mine treatments. In the pre- and post-mining component of this study, I captured fewer snake species in forested treatments than in reclaimed shrub-pole treatments. As mentioned

previously, perhaps snakes are unable to achieve and maintain activity levels as long in the shaded environments of forests as they are in open habitats. It is also possible that smaller patches of off-mine grassland and shrub-pole habitats may have been less able to support large breeding populations of snakes than the large habitat expanses on reclaimed mines.

The short distance from off-mine sampling points to intact forests also likely explains the captures of several salamander species that are typically restricted to forested environments (e.g., Plethodon spp.). Because off-mine treatment sampling points were in areas containing native soils, the topsoil was considerably less compacted than the minesoils of the on-mine treatments. 
This feature probably made the off-mine grassland and shrub-pole habitats more habitable for salamanders.

\section{Summary and Conclusions}

Mountaintop removal mining and its creation of grasslands and shrub-pole habitats appear to negatively impact salamanders (habitat specialists) and positively affect snakes (generalists), understandably so because salamanders are considerably less mobile than snakes and are less likely to cross over reclaimed treatments to move between tracts of forests (Blaustein et al. 1994). Most snake species expected to occur in this study can occur in a variety of habitats. Of the 3 species that are habitat specialists (Timber Rattlesnake (Crotalus horridus), Smooth Greensnake (Opheodrys vernalis), and Northern Red-bellied Snake (Storeria o. occipitomaculata)), 2 prefer forests. Because mountaintop removal mining probably does not benefit all snakes in general, I would not suggest conversion of mature forests to early successional habitats as a management tactic for any herpetofaunal taxa in general, especially considering that species richness and abundance of herpetofauna that require forests (i.e., salamanders) are affected by outright loss of forested habitat and reduction of quality offered from fragmented forests. One may be tempted to observe the diversity present on the 3 postmining habitats as a whole and conclude that mountaintop removal mining is overall more beneficial to herpetofauna than it is harmful. There is a danger in adopting such a philosophy and using it when making management decisions. Generalist species that are not in need of conservation would most likely proliferate while forest interior species for which there is growing concern about their vulnerability may be unable to adapt and sustain their populations

(Noss and Csuti 1997). An interesting theme that recurs among all taxa is that none of them used grasslands over another habitat.

The richest amphibian community of any upland eastern United States forest type occurs within the mixed mesophytic forests of the Appalachian coal fields (Hinkle et al. 1989). Many salamander species and some anuran species in this region require or prefer forested habitats. This area also is where mountaintop removal mining is concentrated. Removal of large expanses of forest greatly limits distribution of salamanders, which may have serious and lasting effects on the amphibian community of the region. Because the return to forested habitats on reclaimed lands is slower than the recovery from other disturbances that remove trees (e.g., silvicultural 
practices), it is not known if salamander populations will be able to recover on these reclaimed mines nor how long it will take. Because deforestation was implicated in the worldwide amphibian decline (Stebbins and Cohen 1995), the mountaintop removal mining technique, which uses a large scale of tree removal coupled with a great upheaval of soil, should raise concerns for its role as a potential contributor to this decline.

Several measures can help ameliorate effects of mining on herpetofuana by enhancing habitat and speeding succession on reclaimed lands. These include placing slash piles throughout reclaimed habitat to serve as refugia and planting vegetation that provides more shade, vertical structure, and leaf litter than grass species. Nitrogen-fixing trees (e.g., black locust) afford these features and still provide the erosion control needed on these disturbed lands. Increased coverage by trees would also reduce temperatures of reclaimed areas and slow evapotranspiration of soil, thereby improving soil and leaf litter microclimate conditions for salamanders (Waldick 1997). Such tree species are already planted as part of reclamation; thus, I am suggesting that they replace grasses as the dominant structure on areas of these mines that would normally be planted entirely with grasses. Grasses should still be planted to grow over the bare ground between the newly planted trees but I caution against planting autumn olive, a shrub commonly planted on reclaimed mountaintop removal mines. This species quickly proliferates and effectively inhibits growth and establishment of native species (Brenner 2000). While it may provide short-term solutions to erosion and mineral deficiency problems, these benefits are outweighed by the long-term complications that it causes. Furthermore, I suggest planting an abundance of other native tree species as well. King and Skousen (2003) planted various tree species on mountaintop removal mines in West Virginia and found that American sycamores, pines (Pinus spp.), white ash, red maple, and black cherry (Prunus serotina) survived.

Therefore, planting of these species should be incorporated into reclamation measures on other mines while endurance of other tree species should also be tested.

My final suggestion is to remove, separate, and set aside $\mathrm{O}$ and A horizons during the soil excavation process and then subsequently replace them in the order removed once mineral extraction is complete. Presence of A horizons would increase the prey base for salamanders. Newly reclaimed minesoils often lack A horizons (Stephens et al., 2001), which is where most invertebrates are found (Plaster, 1997) and its absence effectively minimizes food availability for salamanders that inhabit upland habitats. Richards et al. (1993) stated that organic matter 
improves the water-holding capacity of soil, so if $\mathrm{O}$ horizons, which consist of organic material, were replaced on mountaintop removal mine surfaces, they should make soil more habitable for salamanders, moisture-limited species. Seeding of grasses and legumes may aid reclaimed minesoils in development of A horizons deeper than those of native soils (Thomas et al., 2000). Therefore, retention of A horizons from native soils and their subsequent seeding should produce A horizons deeper than minesoils that were reclaimed with mixtures of soil and unconsolidated rock material. Returning $\mathrm{O}$ and $\mathrm{A}$ horizons would also mean that the unweathered geologic materials would not be on the surface and more options for planting would be available (e.g., increased species selection). Increased tree species richness and abundance may allow a faster return of forests containing native tree species. Current methods of overburden replacement result in minesoils high in rock fragment content and low in aggregate stability, 2 other features that are not conducive to tree growth. A negative effect of reclamation would still be compaction of soil. This is a measure that could not be eliminated or altered. Otherwise, the soil would be too unstable. However, putting other suggestions into effect would drastically reduce negative impacts sustained by salamanders and may permit salamanders from nearby forests to recolonize reclaimed habitats sooner. 
Table 1. Estimated age (in 2002) and elevation of grassland, shrub-pole, fragmented forest, and intact forest treatments having drift fence arrays for sampling herpetofauna and total area (in 2000) of each mined treatment at each mine site. A dashed line indicates that data were not applicable to that treatment or mine site.

\begin{tabular}{|c|c|c|c|c|}
\hline Mine & Grassland & Shrub-pole & Fragmented Forest & Intact Forest \\
\hline \multicolumn{5}{|l|}{ Age (yrs) } \\
\hline Hobet 21 & 16 & 18 & -- & -- \\
\hline Dal-Tex & 10 & -- & -- & -- \\
\hline Cannelton & 18 & 24,28 & -- & -- \\
\hline \multicolumn{5}{|c|}{ Elevation (m) } \\
\hline Hobet 21 & 343 & 335 & 253,358 & 338 \\
\hline Dal-Tex & 473 & -- & -- & 430 \\
\hline Cannelton & 425 & 435,466 & 376 & 566 \\
\hline \multicolumn{5}{|l|}{ Area (ha) } \\
\hline Hobet 21 & 2003 & 428 & 339 & -- \\
\hline Dal-Tex & 1819 & 106 & 155 & -- \\
\hline Cannelton & 1672 & 508 & 214 & -- \\
\hline
\end{tabular}

Table 2. Watersheds and stream drainages with drift fence array sampling points by treatment in 3 watersheds in southern West Virginia.

\begin{tabular}{|c|c|c|c|c|c|}
\hline Watershed (Mine) & Stream Drainages & Grassland & Shrub-pole & $\begin{array}{c}\text { Fragmented } \\
\text { Forest }\end{array}$ & $\begin{array}{l}\text { Intact } \\
\text { Forest }\end{array}$ \\
\hline $\begin{array}{l}\text { Mud River } \\
\quad(\text { Hobet 21) }\end{array}$ & $\begin{array}{l}\text { Big Horse } \\
\text { Lavender Fork } \\
\text { Spring Branch } \\
\text { Long Branch }\end{array}$ & 1 & 1 & $\begin{array}{l}1 \\
1\end{array}$ & 1 \\
\hline $\begin{array}{c}\text { Spruce Fork } \\
\text { (Dal-Tex) }\end{array}$ & $\begin{array}{l}\text { Rockhouse Creek } \\
\text { Pigeonroost Branch } \\
\text { Bend Branch }\end{array}$ & 1 & & & 1 \\
\hline $\begin{array}{l}\text { Twentymile Creek } \\
\text { (Cannelton) }\end{array}$ & $\begin{array}{l}\text { Bullpush Fork } \\
\text { Ash Fork } \\
\text { Hughes Fork }\end{array}$ & 1 & 2 & 1 & 1 \\
\hline
\end{tabular}


Table 3. Number of individuals $(\mathrm{N})$ of herpetofaunal species captured in drift fence arrays and percent of drift fence arrays $(\%)$ at which a species was captured in grassland $(n=3)$, shrub-pole $(n=3)$, fragmented forest $(n=3)$, and intact forest $(n=3)$ treatments on and near mountaintop removal mines in southern West Virginia, 2000-2002.

\begin{tabular}{|c|c|c|c|c|c|c|c|c|}
\hline \multirow[b]{2}{*}{ Species } & \multicolumn{2}{|c|}{ Grassland } & \multicolumn{2}{|c|}{ Shrub-pole } & \multicolumn{2}{|c|}{$\begin{array}{c}\text { Fragmented } \\
\text { Forest }\end{array}$} & \multicolumn{2}{|c|}{ Intact Forest } \\
\hline & $N$ & $\%$ & $N$ & $\%$ & $N$ & $\%$ & $N$ & $\%$ \\
\hline \multicolumn{9}{|l|}{ Salamanders } \\
\hline Cumberland Plateau Salamander & & & & & 2 & 66 & 17 & 66 \\
\hline Eastern Red-backed Salamander & & & & & 2 & 33 & 6 & 33 \\
\hline Four-toed Salamander & 1 & 33 & & & 1 & 33 & & \\
\hline Northern Dusky Salamander & & & & & 1 & 33 & & \\
\hline Northern Red Salamander & & & & & & & 2 & 66 \\
\hline Northern Slimy Salamander & & & 2 & 66 & 9 & 33 & 7 & 33 \\
\hline Red-spotted Newt & 4 & 66 & 8 & 100 & 6 & 66 & 4 & 66 \\
\hline Red Eft & 20 & 100 & 9 & 100 & 36 & 100 & 26 & 100 \\
\hline Seal Salamander & & & & & 2 & 33 & 1 & 33 \\
\hline Spotted Salamander & 2 & 66 & 2 & 33 & 3 & 66 & 1 & 33 \\
\hline Spring Salamander & & & & & 1 & 33 & & \\
\hline Southern Two-lined Salamander & & & & & 2 & 33 & & \\
\hline \multicolumn{9}{|l|}{ Toads and frogs } \\
\hline American Bullfrog & 3 & 33 & 7 & 100 & 5 & 66 & 1 & 33 \\
\hline Cope's Gray Treefrog & & & 4 & 33 & & & & \\
\hline Eastern American Toad & 15 & 100 & 45 & 100 & 11 & 100 & 44 & 100 \\
\hline Fowler's Toad & 3 & 66 & & & & & & \\
\hline Northern Green Frog & 56 & 100 & 55 & 100 & 69 & 100 & 7 & 100 \\
\hline Northern Leopard Frog & 4 & 66 & 9 & 66 & 8 & 100 & 2 & 33 \\
\hline Northern Spring Peeper & & & 1 & 33 & 1 & 33 & 2 & 33 \\
\hline Pickerel Frog & 50 & 100 & 43 & 66 & 76 & 100 & 22 & 66 \\
\hline Wood Frog & & & & & 2 & 66 & 5 & 66 \\
\hline Unidentified Frog & 6 & 66 & 4 & 66 & 2 & 33 & 2 & 66 \\
\hline Unidentified Toad & 3 & 66 & 9 & 100 & 4 & 66 & 13 & 66 \\
\hline \multicolumn{9}{|l|}{ Lizards } \\
\hline Common Five-lined Skink & & & 2 & 66 & 4 & 33 & 4 & 100 \\
\hline Little Brown Skink & 1 & 33 & & & & & 1 & 33 \\
\hline Eastern Fence Lizard & 4 & 66 & 2 & 33 & & & & \\
\hline \multicolumn{9}{|l|}{ Snakes } \\
\hline Eastern Ratsnake & 5 & 66 & 6 & 100 & 2 & 33 & 1 & 33 \\
\hline Common Watersnake & 1 & 33 & 1 & 33 & & & & \\
\hline Eastern Gartersnake & 7 & 66 & 7 & 66 & 14 & 100 & 10 & 66 \\
\hline Eastern Hog-nosed Snake & 1 & 33 & 4 & 66 & & & & \\
\hline Eastern Milksnake & 6 & 66 & 5 & 66 & 7 & 100 & 2 & 66 \\
\hline Eastern Wormsnake & & & & & & & 4 & 66 \\
\hline Northern Black Racer & 19 & 100 & 37 & 100 & & & & \\
\hline Northern Copperhead & 2 & 33 & 14 & 100 & 5 & 100 & 8 & 66 \\
\hline Northern Red-bellied Snake & & & & & 1 & 33 & 1 & 33 \\
\hline Unknown Snake & 1 & 33 & & & & & & \\
\hline \multicolumn{9}{|l|}{ Turtles } \\
\hline$\overline{\text { Eastern Box Turtle }}$ & & & & & 2 & 66 & 1 & 33 \\
\hline
\end{tabular}


Table 4. Herpetofaunal species richness and relative abundance (adjusted per 100 array nights and per trap effort) from drift fence arrays in grassland, shrub-pole, fragmented forest, and intact forest treatments in a reclaimed mountaintop removal mine landscape in southern West Virginia, 2000-2002. Within a row, means with the same letters are not different at á=0.10 (Waller Duncan K-ratio t-test).

\begin{tabular}{|c|c|c|c|c|c|c|c|c|c|c|c|c|c|c|}
\hline & \multicolumn{3}{|c|}{ Grassland } & \multicolumn{3}{|c|}{ Shrub-pole } & \multicolumn{3}{|c|}{ Fragmented Forest } & \multicolumn{3}{|c|}{ Intact Forest } & \multirow[b]{2}{*}{$F$} & \multirow[b]{2}{*}{$P$} \\
\hline & Mean & & $S E$ & Mean & & $S E$ & Mean & & $S E$ & Mean & & $S E$ & & \\
\hline \multicolumn{15}{|l|}{ Species Richness } \\
\hline Overall Herpetofauna & 1.20 & A & 0.13 & 1.69 & A & 0.15 & 1.74 & A & 0.16 & 1.26 & A & 0.14 & 1.41 & 0.33 \\
\hline Amphibians & 0.69 & A & 0.10 & 0.95 & A & 0.14 & 1.41 & $\mathrm{~A}$ & 0.15 & 1.12 & A & 0.13 & 2.86 & 0.13 \\
\hline Salamanders & 0.21 & $\mathrm{~B}$ & 0.05 & 0.27 & $\mathrm{~B}$ & 0.07 & 0.59 & $\mathrm{~A}$ & 0.08 & 0.59 & A & 0.09 & 6.99 & 0.03 \\
\hline Toads and Frogs & 0.48 & A & 0.08 & 0.68 & A & 0.11 & 0.83 & A & 0.11 & 0.53 & A & 0.09 & 0.73 & 0.57 \\
\hline Reptiles & 0.51 & $\mathrm{AB}$ & 0.08 & 0.74 & A & 0.09 & 0.33 & $\mathrm{~B}$ & 0.06 & 0.34 & $\mathrm{~B}$ & 0.07 & 3.96 & 0.07 \\
\hline Snakes & 0.44 & $\mathrm{AB}$ & 0.07 & 0.68 & A & 0.08 & 0.29 & $\mathrm{~B}$ & 0.05 & 0.22 & $\mathrm{~B}$ & 0.05 & 4.65 & 0.06 \\
\hline \multicolumn{15}{|l|}{$\underline{\text { Abundance }}$} \\
\hline Overall Herpetofauna & 2.53 & A & 0.53 & 3.18 & A & 0.46 & 3.22 & A & 0.39 & 2.01 & A & 0.27 & 0.58 & 0.65 \\
\hline Amphibians & 1.97 & A & 0.53 & 2.26 & A & 0.45 & 2.82 & A & 0.39 & 1.94 & A & 0.28 & 0.63 & 0.62 \\
\hline Salamanders & 0.39 & $\mathrm{~B}$ & 0.11 & 0.35 & B & 0.10 & 0.84 & A & 0.13 & 0.74 & A & 0.14 & 3.48 & 0.09 \\
\hline Red Eft & 0.27 & A & 0.11 & 0.12 & A & 0.06 & 0.31 & A & 0.08 & 0.28 & A & 0.10 & 0.42 & 0.74 \\
\hline Family Plethodontidae & 0.02 & B & 0.02 & 0.04 & B & 0.03 & 0.28 & $\mathrm{AB}$ & 0.08 & 0.41 & A & 0.08 & 5.55 & 0.04 \\
\hline Genus Plethodon & 0.00 & $\mathrm{~B}$ & 0.00 & 0.04 & B & 0.03 & 0.19 & B & 0.06 & 0.37 & A & 0.08 & 5.56 & 0.04 \\
\hline \multicolumn{15}{|l|}{ Toads and Frogs } \\
\hline Family Bufonidae & 0.23 & A & 0.08 & 0.54 & A & 0.21 & 0.16 & A & 0.06 & 0.58 & A & 0.17 & 1.39 & 0.33 \\
\hline Eastern American Toad & 0.17 & A & 0.06 & 0.47 & A & 0.19 & 0.11 & $\mathrm{~A}$ & 0.04 & 0.41 & A & 0.11 & 1.23 & 0.38 \\
\hline Family Ranidae & 1.36 & A & 0.45 & 1.30 & A & 0.30 & 1.81 & A & 0.32 & 0.40 & A & 0.10 & 1.94 & 0.22 \\
\hline Northern Green Frog & 0.59 & A & 0.29 & 0.61 & A & 0.16 & 0.71 & A & 0.20 & 0.06 & A & 0.02 & 2.25 & 0.18 \\
\hline Pickerel Frog & 0.60 & A & 0.30 & 0.46 & A & 0.14 & 0.89 & A & 0.16 & 0.23 & A & 0.09 & 1.07 & 0.43 \\
\hline Reptiles & 0.56 & $\mathrm{AB}$ & 0.09 & 0.92 & A & 0.12 & 0.40 & $\mathrm{~B}$ & 0.08 & 0.33 & $\mathrm{~B}$ & 0.07 & 4.10 & 0.07 \\
\hline Snakes & 0.49 & $\mathrm{AB}$ & 0.08 & 0.86 & A & 0.12 & 0.34 & B & 0.07 & 0.25 & $\mathrm{~B}$ & 0.07 & 4.12 & 0.07 \\
\hline Family Colubridae & 0.46 & $\mathrm{AB}$ & 0.08 & 0.70 & A & 0.10 & 0.30 & $\mathrm{~B}$ & 0.07 & 0.18 & $\mathrm{~B}$ & 0.06 & 3.73 & 0.08 \\
\hline Eastern Gartersnake & 0.07 & A & 0.03 & 0.07 & A & 0.03 & 0.17 & A & 0.05 & 0.10 & A & 0.04 & 0.36 & 0.78 \\
\hline Northern Black Racer & 0.23 & $\mathrm{~B}$ & 0.05 & 0.45 & A & 0.08 & 0.00 & $\mathrm{C}$ & 0.00 & 0.00 & $\mathrm{C}$ & 0.00 & 8.97 & 0.01 \\
\hline
\end{tabular}


Table 5. Number of individuals and species $(\mathrm{N})$ and proportion of total individuals and total species (\%) of herpetofaunal groups captured in drift fence arrays in grassland, shrub-pole, fragmented forest, and intact forest treatments in a reclaimed mountaintop removal mine landscape in

southern West Virginia, 2000-2002.

\begin{tabular}{|c|c|c|c|c|c|c|c|c|c|c|c|c|c|c|c|c|}
\hline \multirow[b]{3}{*}{ Taxonomic Group } & \multicolumn{4}{|c|}{ Grassland } & \multicolumn{4}{|c|}{ Shrub-pole } & \multicolumn{4}{|c|}{ Fragmented Forest } & \multicolumn{4}{|c|}{ Intact Forest } \\
\hline & \multicolumn{2}{|c|}{ Individuals } & \multicolumn{2}{|c|}{ Species } & \multicolumn{2}{|c|}{ Individuals } & \multicolumn{2}{|c|}{ Species } & \multicolumn{2}{|c|}{ Individuals } & \multicolumn{2}{|c|}{ Species } & \multicolumn{2}{|c|}{ Individuals } & \multicolumn{2}{|c|}{ Species } \\
\hline & $N$ & $\%$ & $N$ & $\%$ & $N$ & $\%$ & $N$ & $\%$ & $N$ & $\%$ & $N$ & $\%$ & $N$ & $\%$ & $N$ & $\%$ \\
\hline Salamanders & 28 & 13.0 & 3 & 16.7 & 21 & 7.6 & 3 & 15.8 & 65 & 23.4 & 10 & 43.5 & 64 & 33.0 & 7 & 28.0 \\
\hline Toads and Frogs & 140 & 65.1 & 6 & 33.3 & 177 & 64.1 & 7 & 36.8 & 178 & 64.0 & 6 & 26.1 & 98 & 50.5 & 9 & 36.0 \\
\hline Lizards & 5 & 2.3 & 2 & 11.1 & 4 & 1.4 & 2 & 10.5 & 4 & 1.4 & 1 & 4.3 & 5 & 2.6 & 2 & 8.0 \\
\hline Snakes & 42 & 19.5 & 7 & 38.9 & 74 & 26.8 & 7 & 36.8 & 29 & 10.4 & 5 & 21.7 & 26 & 13.4 & 6 & 24.0 \\
\hline Turtles & 0 & 0.0 & 0 & 0.0 & 0 & 0.0 & 0 & 0.0 & 2 & 0.7 & 1 & 4.3 & 1 & 0.5 & 1 & 4.0 \\
\hline
\end{tabular}


Table 6. Mean and standard error (SE) for habitat variables measured at grassland $(n=3)$, shrub-pole $(n=3)$, fragmented forest $(n=3)$, and intact forest $(n=3)$ treatments in a reclaimed mountaintop removal mine landscape in southern West Virginia, 2002. Dashed lines indicate treatments where variables were not measured. Within a row, means with the same letters are not different at á $=0.10$ (Waller Duncan K-ratio t-test).

\begin{tabular}{|c|c|c|c|c|c|c|c|c|c|c|c|c|c|c|}
\hline \multirow[b]{2}{*}{ Variables } & \multicolumn{3}{|c|}{ Grassland } & \multicolumn{3}{|c|}{ Shrub-pole } & \multicolumn{3}{|c|}{ Fragmented Forest } & \multicolumn{3}{|c|}{ Intact forest } & \multirow[b]{2}{*}{$F$} & \multirow[b]{2}{*}{$P$} \\
\hline & Mean & & $\overline{S E}$ & Mean & & $\overline{S E}$ & Mean & & $\overline{S E}$ & Mean & & $\overline{S E}$ & & \\
\hline Slope (\%) & 22.42 & $\mathrm{AB}$ & 5.23 & 11.40 & $\bar{B}$ & 4.35 & 40.09 & $\mathrm{~A}$ & 4.99 & 34.42 & $\mathrm{~A}$ & 5.25 & 3.15 & $\overline{0.11}$ \\
\hline Aspect $\left(^{\circ}\right)$ & 196.42 & A & 35.14 & 222.40 & A & 33.81 & 215.00 & A & 42.67 & 191.83 & A & 13.30 & 0.46 & 0.72 \\
\hline Aspect Code & 1.06 & A & 0.22 & 1.26 & A & 0.17 & 1.21 & A & 0.27 & 1.03 & A & 0.22 & 0.46 & 0.72 \\
\hline Organic Litter Depth (cm) & 2.47 & A & 0.21 & 3.76 & A & 0.25 & 3.38 & A & 0.35 & 3.63 & A & 0.33 & 0.21 & 0.89 \\
\hline Distance to Edge (m) & 52.91 & A & 8.76 & 58.20 & A & 10.95 & 34.73 & A & 8.31 & 35.42 & A & 7.77 & 2.59 & 0.15 \\
\hline Robel Pole Index & 2.24 & $\mathrm{~B}$ & 0.17 & 4.26 & A & 0.27 & ----- & & ----- & ----- & & ----- & 0.27 & 0.66 \\
\hline Canopy Height (m) & ----- & & ----- & 33.80 & B & 4.06 & 73.82 & A & 4.47 & 80.17 & A & 3.48 & 17.54 & 0.01 \\
\hline Green Height (forb and grass height; dm) & 6.71 & $\mathrm{~B}$ & 0.21 & 8.76 & A & 0.34 & ----- & & ----- & ----- & & ----- & 1.56 & 0.34 \\
\hline \multicolumn{15}{|l|}{ Ground Cover (\%) } \\
\hline Water & 0.00 & A & 0.00 & 0.00 & $\mathrm{AB}$ & 0.00 & 0.91 & A & 0.91 & 0.00 & A & 0.00 & 1.36 & 0.34 \\
\hline Bareground / rock & 5.00 & $\mathrm{BC}$ & 3.43 & 0.50 & $\mathrm{C}$ & 0.50 & 4.09 & B & 1.89 & 11.67 & A & 3.16 & 3.61 & 0.08 \\
\hline Leaf Litter & 20.42 & $\mathrm{~B}$ & 4.58 & 48.50 & A & 7.42 & 67.73 & A & 6.62 & 69.58 & A & 2.57 & 9.39 & 0.01 \\
\hline Woody Debris & 0.00 & $\mathrm{~B}$ & 0.00 & 0.00 & B & 0.00 & 2.27 & $\mathrm{AB}$ & 1.83 & 2.92 & A & 0.96 & 3.58 & 0.09 \\
\hline Moss & 0.00 & A & 0.00 & 3.50 & A & 1.50 & 3.18 & A & 1.39 & 1.67 & A & 0.94 & 0.98 & 0.46 \\
\hline Green & 72.92 & A & 6.64 & 47.50 & $\mathrm{AB}$ & 7.83 & 21.82 & $\mathrm{BC}$ & 6.58 & 14.17 & $\mathrm{C}$ & 1.72 & 10.01 & 0.01 \\
\hline Lespedeza & 38.13 & A & 10.81 & 35.50 & A & 9.47 & 0.00 & B & 0.00 & 0.00 & B & 0.00 & 4.68 & 0.05 \\
\hline \multicolumn{15}{|l|}{ Stem Densities (no./ha) } \\
\hline$<8 \mathrm{~cm}$ & 1507.43 & $\mathrm{~B}$ & 1183.40 & 15106.16 & A & 1167.45 & 4508.14 & B & 1666.02 & 14373.67 & A & 5016.65 & 5.55 & 0.04 \\
\hline $8-38 \mathrm{~cm}$ & 0.00 & $\mathrm{~B}$ & 0.00 & 369.44 & A & 130.20 & 340.98 & A & 53.88 & 410.42 & A & 16.27 & 5.63 & 0.04 \\
\hline$>38 \mathrm{~cm}$ & 0.00 & $\mathrm{C}$ & 0.00 & 0.00 & $\mathrm{C}$ & 0.00 & 48.61 & A & 11.87 & 22.92 & B & 4.17 & 11.26 & 0.01 \\
\hline \multicolumn{15}{|l|}{ Canopy Cover (\%) } \\
\hline$>0.5-3 \mathrm{~m}$ & 0.83 & $\mathrm{D}$ & 0.56 & 39.00 & A & 5.95 & 36.36 & B & 5.31 & 35.00 & $\mathrm{C}$ & 4.52 & 24.48 & 0.00 \\
\hline$>3-6 m$ & 0.00 & $\mathrm{C}$ & 0.00 & 42.00 & B & 7.68 & 64.55 & A & 5.24 & 52.08 & $\mathrm{AB}$ & 6.84 & 16.20 & 0.00 \\
\hline$>6-12 \mathrm{~m}$ & 0.00 & $\mathrm{C}$ & 0.00 & 12.00 & B & 6.55 & 70.45 & A & 6.01 & 68.33 & A & 4.10 & 23.05 & 0.00 \\
\hline$>12 \mathrm{~m}$ & 0.00 & B & 0.00 & 0.00 & B & 0.13 & 29.27 & A & 5.14 & 28.42 & A & 2.56 & 82.22 & $<0.0001$ \\
\hline
\end{tabular}


Table 7. Herpetofaunal species richness and relative abundance (adjusted per 100 array nights and per trap effort) from drift fence arrays in on- and off-mine treatments in a reclaimed mountaintop removal mine landscape in southern West Virginia, 2002. Within a row, means with the same letters are not different at á $=0.10$ (Waller Duncan K-ratio $t$ test).

\begin{tabular}{|c|c|c|c|c|c|c|c|c|c|c|c|c|}
\hline & \multicolumn{3}{|c|}{$\begin{array}{l}\text { On-Mine } \\
\text { Grassland }\end{array}$} & \multicolumn{2}{|c|}{$\begin{array}{l}\text { On-Mine } \\
\text { Shrub-pole }\end{array}$} & \multicolumn{3}{|c|}{$\begin{array}{l}\text { Off-Mine } \\
\text { Grassland }\end{array}$} & \multicolumn{2}{|c|}{$\begin{array}{c}\text { Off-Mine } \\
\text { Shrub-pole }\end{array}$} & \multirow[b]{2}{*}{$F$} & \multirow[b]{2}{*}{$P$} \\
\hline & Mean & $S E$ & & Mean & $S E$ & Mean & $S E$ & & Mean & $S E$ & & \\
\hline \multicolumn{13}{|l|}{ Richness } \\
\hline Overall Herpetofauna & 1.29 & 0.24 & A & 1.64 & 0.29 & 0.98 & 0.15 & A & 1.18 & 0.23 & 1.52 & 0.25 \\
\hline Amphibians & 0.79 & 0.18 & A & 1.04 & 0.24 & 0.57 & 0.16 & A & 0.81 & 0.19 & 0.72 & 0.42 \\
\hline Salamanders & 0.28 & 0.10 & A & 0.29 & 0.13 & 0.22 & 0.08 & $\mathrm{~A}$ & 0.36 & 0.14 & 0.00 & 0.98 \\
\hline Toads and Frogs & 0.51 & 0.13 & A & 0.75 & 0.20 & 0.36 & 0.13 & A & 0.46 & 0.14 & 1.20 & 0.30 \\
\hline Reptiles & 0.50 & 0.12 & A & 0.60 & 0.14 & 0.41 & 0.09 & $\mathrm{~B}$ & 0.37 & 0.15 & 3.98 & 0.08 \\
\hline Snakes & 0.43 & 0.10 & A & 0.60 & 0.14 & 0.32 & 0.09 & B & 0.33 & 0.11 & 4.65 & 0.06 \\
\hline \multicolumn{13}{|l|}{$\underline{\text { Abundance }}$} \\
\hline Overall Herpetofauna & 2.36 & 0.50 & A & 3.01 & 0.60 & 1.55 & 0.27 & A & 2.59 & 0.56 & 0.80 & 0.40 \\
\hline Amphibians & 1.73 & 0.46 & A & 2.19 & 0.57 & 1.00 & 0.30 & A & 1.96 & 0.57 & 0.59 & 0.47 \\
\hline Salamanders & 0.79 & 0.30 & A & 0.39 & 0.17 & 0.25 & 0.09 & A & 0.49 & 0.18 & 0.89 & 0.37 \\
\hline Toads and Frogs & 0.95 & 0.25 & A & 1.80 & 0.58 & 0.75 & 0.27 & A & 1.47 & 0.59 & 0.23 & 0.64 \\
\hline Family Bufonidae & 0.31 & 0.12 & A & 0.49 & 0.26 & 0.49 & 0.21 & A & 0.93 & 0.48 & 0.82 & 0.39 \\
\hline Eastern American Toad & 0.21 & 0.10 & A & 0.27 & 0.10 & 0.26 & 0.14 & A & 0.45 & 0.36 & 0.35 & 0.57 \\
\hline Family Ranidae & 0.64 & 0.23 & A & 1.23 & 0.42 & 0.22 & 0.11 & A & 0.54 & 0.20 & 2.99 & 0.12 \\
\hline Pickerel Frog & 0.27 & 0.20 & A & 0.55 & 0.24 & 0.07 & 0.05 & A & 0.28 & 0.14 & 1.20 & 0.31 \\
\hline Reptiles & 0.62 & 0.14 & A & 0.82 & 0.19 & 0.55 & 0.12 & A & 0.63 & 0.21 & 1.44 & 0.26 \\
\hline Snakes & 0.54 & 0.11 & A & 0.82 & 0.19 & 0.45 & 0.12 & A & 0.58 & 0.19 & 2.4 & 0.16 \\
\hline Family Colubridae & 0.49 & 0.11 & A & 0.59 & 0.19 & 0.21 & 0.08 & A & 0.50 & 0.17 & 1.83 & 0.18 \\
\hline
\end{tabular}


Table 8. Number of individuals and species of herpetofaunal groups captured in drift fence arrays in on - and off-mine treatments in southern West Virginia, 2002.

\begin{tabular}{|c|c|c|c|c|c|c|c|c|c|c|c|c|c|c|c|c|}
\hline \multirow[b]{3}{*}{ Taxonomic Group } & \multicolumn{4}{|c|}{ On-mine Grassland } & \multicolumn{4}{|c|}{ On-mine Shrub-pole } & \multicolumn{4}{|c|}{ Off-mine Grassland } & \multicolumn{4}{|c|}{ Off-mine Shrub-pole } \\
\hline & \multicolumn{2}{|c|}{ Individuals } & \multicolumn{2}{|c|}{ Species } & \multirow{2}{*}{\multicolumn{2}{|c|}{ Individuals }} & \multicolumn{2}{|c|}{ Species } & \multicolumn{2}{|c|}{ Individuals } & \multicolumn{2}{|c|}{ Species } & \multicolumn{2}{|c|}{ Individuals } & \multicolumn{2}{|c|}{ Species } \\
\hline & $N$ & $\%$ & $N$ & $\%$ & & & $N$ & $\%$ & $N$ & $\%$ & $N$ & $\%$ & $N$ & $\%$ & $N$ & $\%$ \\
\hline Salamanders & 17 & 28.3 & 2 & 15.4 & 7 & & 3 & 21.4 & 6 & 13.6 & 4 & 23.5 & 10 & 13.9 & 5 & 29.4 \\
\hline Toads and Frogs & 26 & 43.3 & 6 & 46.2 & 59 & & 6 & 42.9 & 22 & 50.0 & 6 & 35.3 & 44 & 61.1 & 7 & 41.2 \\
\hline Lizards & 2 & 3.3 & 1 & 7.7 & 0 & 0.0 & 0 & 0.0 & 2 & 4.5 & 2 & 11.8 & 1 & 1.4 & 1 & 5.9 \\
\hline Snakes & 15 & 25.0 & 4 & 30.8 & 21 & 24.1 & 5 & 35.7 & 14 & 31.8 & 5 & 29.4 & 17 & 23.6 & 4 & 23.5 \\
\hline
\end{tabular}


Table 9. Number of individuals $(N)$ of herpetofaunal species captured in drift fence arrays and percent of drift fence arrays $(\%)$ at which a species was captured in on-mine $(n=6)$ and off-mine $(n=6)$ treatments on and near mountaintop removal mines in southern West Virginia, 2002.

\begin{tabular}{|c|c|c|c|c|c|c|c|c|}
\hline \multirow[b]{2}{*}{ Species } & \multicolumn{2}{|c|}{$\begin{array}{l}\text { On-mine } \\
\text { Grassland }\end{array}$} & \multicolumn{2}{|c|}{$\begin{array}{c}\text { On-mine } \\
\text { Shrub-pole }\end{array}$} & \multicolumn{2}{|c|}{$\begin{array}{l}\text { Off-mine } \\
\text { Grassland }\end{array}$} & \multicolumn{2}{|c|}{$\begin{array}{c}\text { Off-mine } \\
\text { Shrub-pole }\end{array}$} \\
\hline & $N$ & $\%$ & $N$ & $\%$ & $N$ & $\%$ & $N$ & $\%$ \\
\hline \multicolumn{9}{|l|}{ Salamanders } \\
\hline Cumberland Plateau Salamander & & & & & & & 1 & 33 \\
\hline Eastern Red-backed Salamander & & & & & & & 1 & 33 \\
\hline Four-toed Salamander & & & & & & & 1 & 33 \\
\hline Northern Red Salamander & & & & & 1 & 33 & 1 & 33 \\
\hline Northern Slimy Salamander & & & 2 & 66 & & & & \\
\hline Red-spotted Newt & 1 & 33 & 2 & 33 & & & & \\
\hline Red Eft & 15 & 100 & 2 & 66 & 3 & 100 & 6 & 66 \\
\hline Spotted Salamander & 1 & 33 & 1 & 33 & 1 & 33 & & \\
\hline Southern Two-lined Salamander & & & & & 1 & 33 & & \\
\hline \multicolumn{9}{|l|}{$\underline{\text { Toads and frogs }}$} \\
\hline American Bullfrog & 1 & 33 & 3 & 66 & 2 & 66 & 1 & 33 \\
\hline Cope's Gray Treefrog & & & 2 & 33 & & & & \\
\hline Eastern American Toad & 6 & 100 & 9 & 100 & 8 & 66 & 14 & 66 \\
\hline Fowler's Toad & 1 & 33 & & & & & 2 & 66 \\
\hline Northern Green Frog & 3 & 33 & 9 & 100 & 1 & 33 & 1 & 33 \\
\hline Northern Leopard Frog & 4 & 66 & 7 & 66 & & & 2 & 33 \\
\hline Northern Spring Peeper & & & & & 1 & 33 & & \\
\hline Pickerel Frog & 7 & 66 & 18 & 66 & 2 & 33 & 9 & 66 \\
\hline Wood Frog & & & & & 1 & 33 & 1 & 33 \\
\hline Unidentified Frog & 1 & 33 & 2 & 33 & & & 1 & 33 \\
\hline Unidentified Toad & 3 & 66 & 9 & 100 & 7 & 100 & 13 & 100 \\
\hline \multicolumn{9}{|l|}{ Lizards } \\
\hline Common Five-lined Skink & & & & & & & 1 & 33 \\
\hline Little Brown Skink & & & & & 1 & 33 & & \\
\hline Eastern Fence Lizard & 2 & 33 & & & 1 & 33 & & \\
\hline \multicolumn{9}{|l|}{ Snakes } \\
\hline$\overline{\text { Eastern Gartersnake }}$ & 1 & 33 & 1 & 33 & 2 & 33 & 13 & 100 \\
\hline Common Ribbonsnake & & & & & & & 1 & 33 \\
\hline Eastern Hog-nosed Snake & & & 2 & 33 & & & & \\
\hline Eastern Milksnake & 2 & 66 & 2 & 66 & 2 & 66 & 2 & 33 \\
\hline Northern Black Racer & 10 & 100 & 10 & 100 & 2 & 33 & & \\
\hline Northern Copperhead & 1 & 33 & 6 & 100 & 7 & 100 & 2 & 33 \\
\hline Northern Ring-necked Snake & & & & & 1 & 33 & & \\
\hline Unknown Snake & 1 & 33 & & & & & & \\
\hline
\end{tabular}


Table 10. Mean and standard error (SE) for habitat variables measured at on-mine $(n=6)$ and off-mine $(n=6)$ treatments in grassland and shrub-pole habitats in a reclaimed mountaintop removal mine landscape in southern West Virginia, 2002. Dashed lines indicate variables that had insufficient data to conduct statistical analyses or that had a significant interaction between treatment and habitat. Statistical results are from comparison of on- and off-mine treatments (grassland and shrub-pole habitats combined).

\begin{tabular}{|c|c|c|c|c|c|c|c|c|c|c|c|}
\hline \multirow[b]{2}{*}{ Variables } & \multicolumn{2}{|c|}{$\begin{array}{l}\text { On-mine } \\
\text { Grassland }\end{array}$} & \multicolumn{2}{|c|}{$\begin{array}{c}\text { On-mine } \\
\text { Shrub-pole }\end{array}$} & \multicolumn{2}{|c|}{$\begin{array}{l}\text { Off-mine } \\
\text { Grassland }\end{array}$} & \multicolumn{3}{|c|}{$\begin{array}{l}\text { Off-mine } \\
\text { Shrub-pole }\end{array}$} & \multirow[b]{2}{*}{$F$} & \multirow[b]{2}{*}{$P$} \\
\hline & Mean & $S E$ & Mean & $S E$ & Mean & $S E$ & & Mean & $S E$ & & \\
\hline Slope $(\%)$ & 22.42 & $5.23 \mathrm{~A}$ & 11.40 & 4.35 & 19.27 & 5.49 & $\mathrm{~A}$ & 8.92 & 4.10 & 0.01 & $\overline{0.92}$ \\
\hline Aspect $\left({ }^{\circ}\right)$ & 196.42 & $35.14 \mathrm{~A}$ & 222.40 & 33.81 & 236.46 & 33.65 & A & 193.33 & 33.28 & 0.02 & 0.90 \\
\hline Aspect Code & 1.06 & $0.22 \mathrm{~A}$ & 1.26 & 0.17 & 0.99 & 0.23 & A & 1.25 & 0.19 & 0.02 & 0.90 \\
\hline Organic Litter Depth (cm) & 2.47 & $0.21 \mathrm{~A}$ & 3.76 & 0.25 & 1.33 & 0.13 & B & 1.25 & 0.14 & 5.92 & 0.04 \\
\hline Elevation & 413.67 & $37.95 \mathrm{~B}$ & 412.00 & 39.53 & 818.00 & 42.00 & A & 716.00 & 18.15 & 49.84 & 0.09 \\
\hline Distance to Edge (m) & 52.91 & $8.76 \mathrm{~A}$ & 58.20 & 10.95 & 22.15 & 6.39 & B & 20.46 & 4.68 & 21.11 & 0.002 \\
\hline Robel Pole Index & 2.24 & $0.17 \mathrm{~A}$ & 4.26 & 0.27 & 2.18 & 0.30 & A & 2.07 & 0.24 & 0.95 & 0.36 \\
\hline Canopy Height (m) & -- & $--\mathrm{B}$ & 33.80 & 4.06 & 30.36 & 9.83 & A & 63.00 & 7.82 & 8.53 & 0.03 \\
\hline Green Height (dm) & 6.71 & $0.21 \mathrm{~A}$ & 8.76 & 0.34 & 6.60 & 0.37 & A & 6.16 & 0.36 & 2.32 & 0.16 \\
\hline \multicolumn{12}{|l|}{ Ground Cover (\%) } \\
\hline Water & 0.00 & 0.00 & 0.00 & 0.00 & 0.00 & 0.00 & & 0.00 & 0.00 & ----- & ----- \\
\hline Bareground / rock & 5.00 & $3.43 \mathrm{~B}$ & 0.50 & 0.50 & 11.36 & 5.05 & A & 9.17 & 3.79 & 3.51 & 0.10 \\
\hline Litter & 20.42 & $4.58 \mathrm{~B}$ & 48.50 & 7.42 & 42.73 & 7.67 & B & 44.17 & 8.28 & 5.70 & 0.04 \\
\hline Woody Debris & 0.00 & $0.00 \mathrm{~A}$ & 0.00 & 0.00 & 0.91 & 0.91 & A & 0.42 & 0.42 & 1.89 & 0.21 \\
\hline Moss & 0.00 & $0.00 \mathrm{~A}$ & 3.50 & 1.50 & 1.36 & 1.36 & A & 0.83 & 0.56 & 0.08 & 0.79 \\
\hline Green & 72.92 & $6.64 \mathrm{~A}$ & 47.50 & 7.83 & 43.64 & 7.07 & A & 45.42 & 8.11 & 2.55 & 0.15 \\
\hline Lespedeza & 38.13 & $10.81 \mathrm{~A}$ & 35.50 & 9.47 & 0.45 & 0.45 & B & 0.00 & 0.00 & 17.99 & 0.003 \\
\hline \multicolumn{12}{|l|}{ Stem Densities (no./ha) } \\
\hline$<8 \mathrm{~cm}$ & 1507.43 & 1183.4 & 15106.16 & 1167.45 & 5454.55 & 2191.93 & & 12653.93 & 2134.98 & ----- & ----- \\
\hline $8-38 \mathrm{~cm}$ & 0.00 & $0.00 \mathrm{~A}$ & 369.44 & 130.20 & 143.18 & 6.67 & A & 256.25 & 90.30 & 0.06 & 0.81 \\
\hline$>38 \mathrm{~cm}$ & 0.00 & $0.00 \mathrm{~B}$ & 0.00 & 0.00 & 13.64 & 7.81 & A & 14.58 & 4.82 & 9.80 & 0.01 \\
\hline \multicolumn{12}{|l|}{ Canopy Cover (\%) } \\
\hline$>0.5-3 \mathrm{~m}$ & 0.83 & $0.56 \mathrm{~B}$ & 39.00 & 5.95 & 16.82 & 6.30 & A & 52.92 & 7.55 & 9.25 & 0.02 \\
\hline$>3-6 \mathrm{~m}$ & 0.00 & 0.00 & 42.00 & 7.68 & 27.27 & 11.78 & & 55.00 & 8.46 & ----- & ---- \\
\hline$>6-12 \mathrm{~m}$ & 0.00 & $0.00 \mathrm{~B}$ & 12.00 & 6.55 & 21.82 & 9.78 & A & 47.08 & 9.89 & 28.91 & 0.0007 \\
\hline$>12 \mathrm{~m}$ & 0.00 & $0.00 \mathrm{~B}$ & 0.00 & 0.13 & 5.00 & 2.29 & A & 13.58 & 4.65 & 46.52 & 0.0001 \\
\hline
\end{tabular}




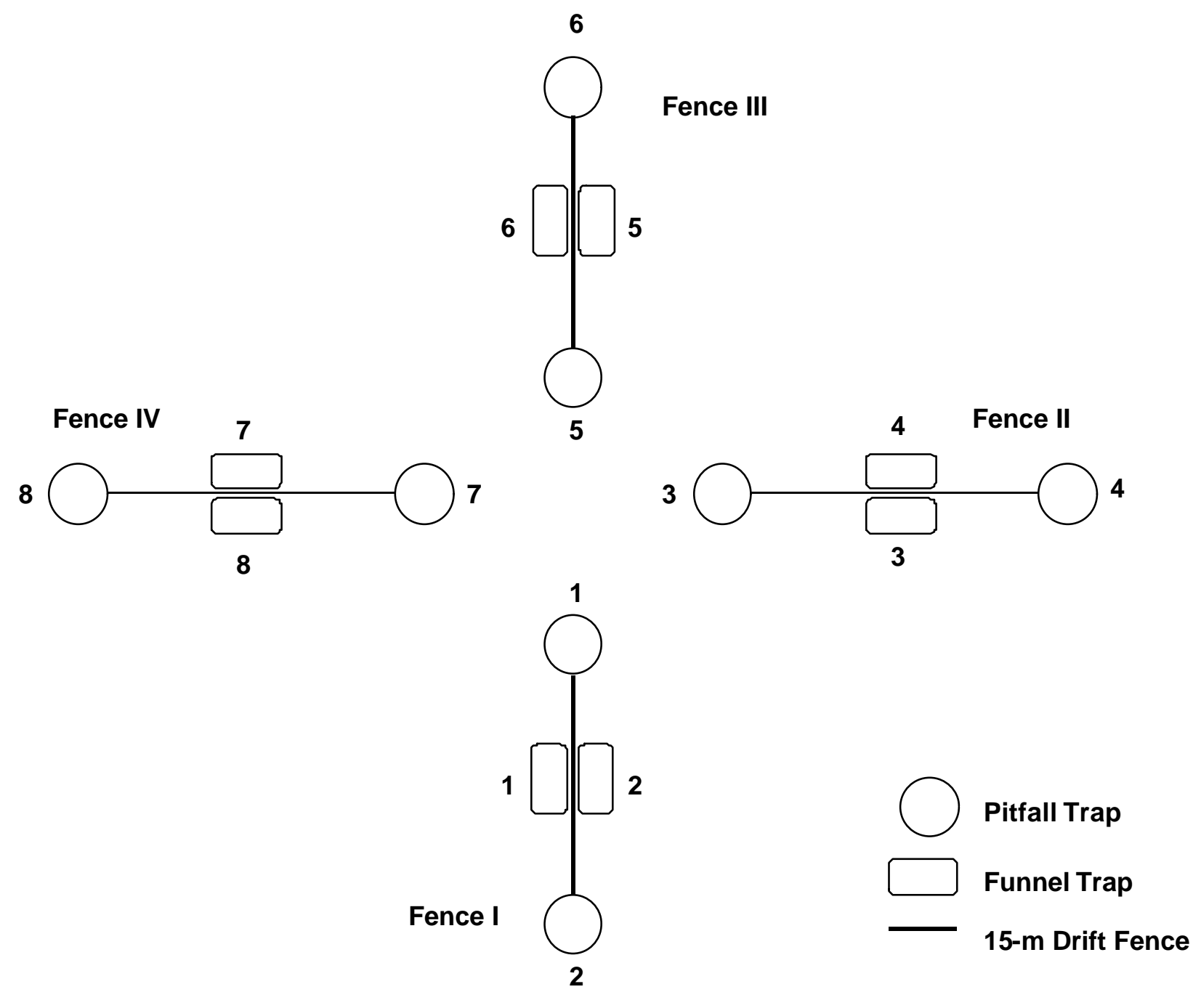

STREAM OR ROAD

Figure 1. Placement of herpetofaunal drift fence array relative to road or stream. The central separation between drift fences was $15 \mathrm{~m}$; figure is not to scale. 


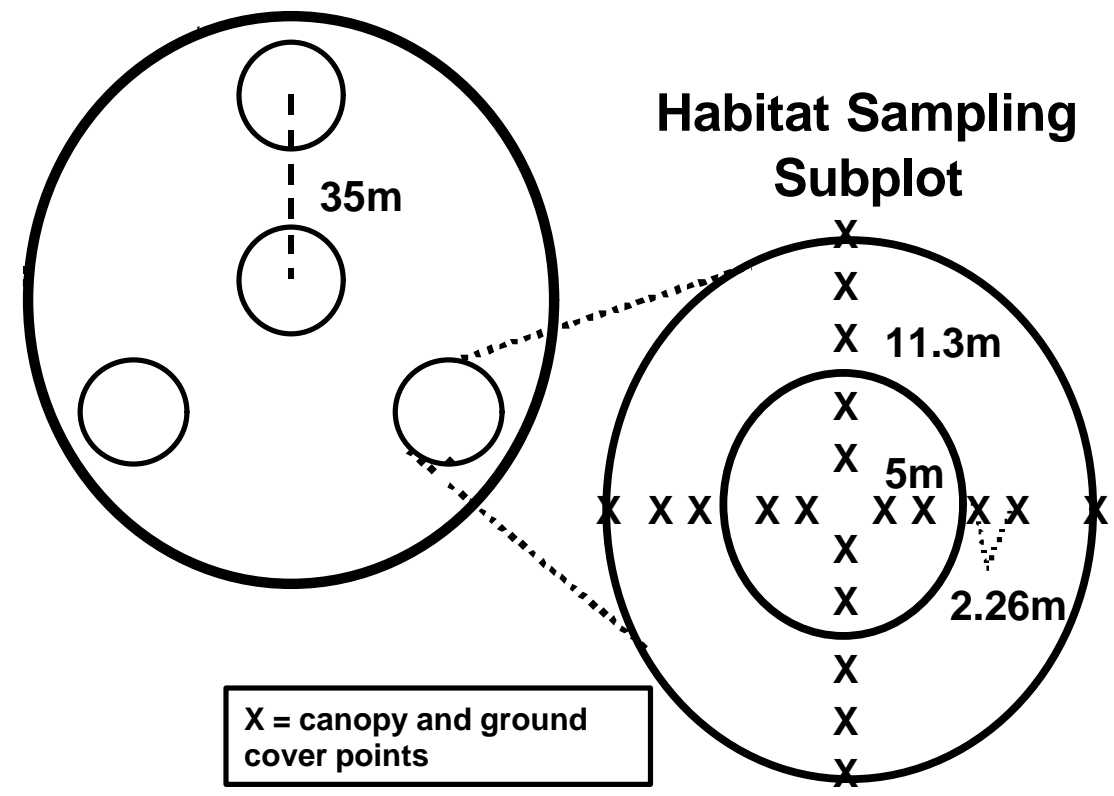

Figure 2. Placement of vegetation sampling plots at the center of drift fence arrays and $35 \mathrm{~m}$ from the center at $0^{\circ}, 120^{\circ}$, and $240^{\circ}$. 


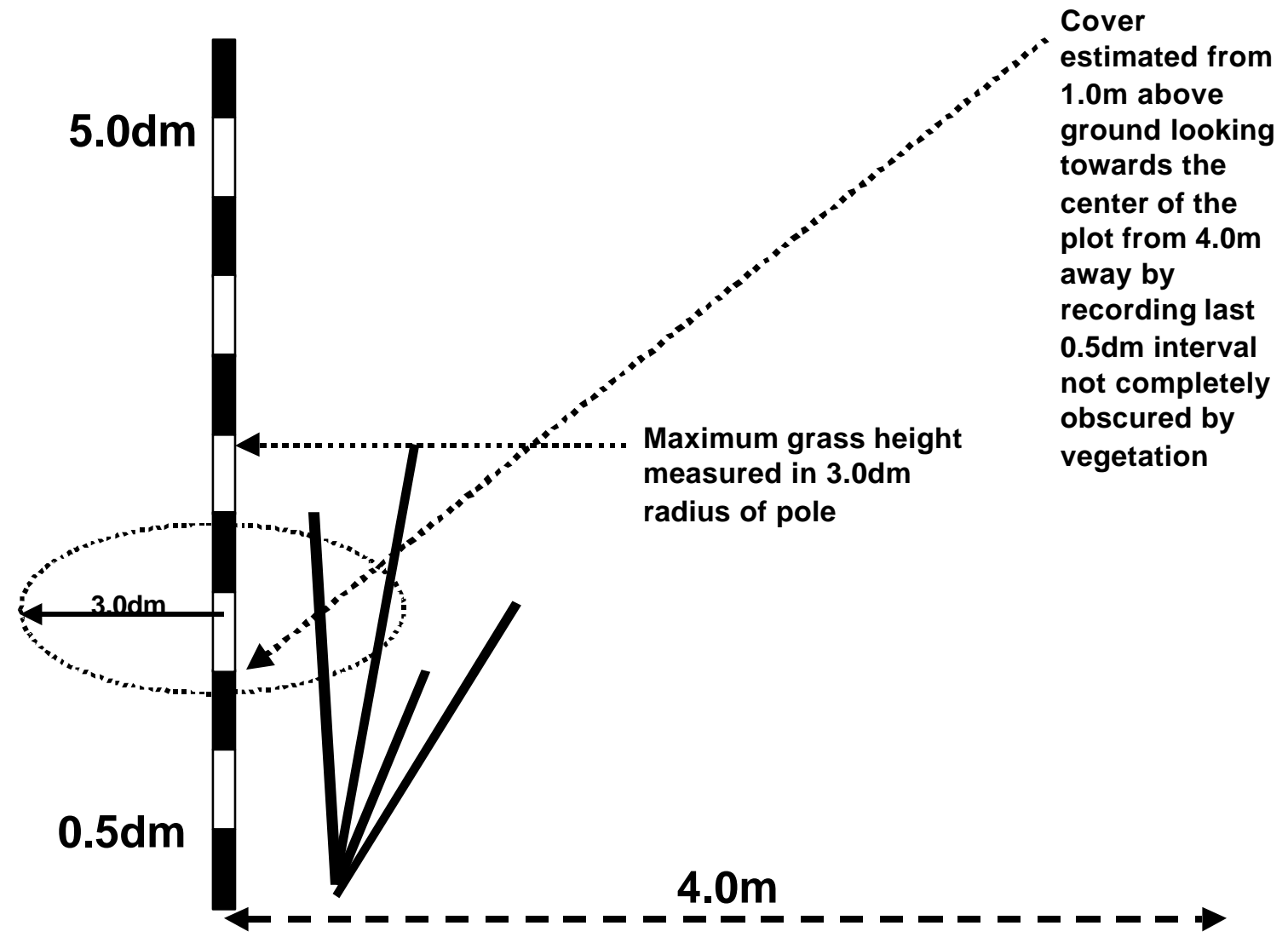

Figure 3. Example of how a Robel pole is used to measure vegetative cover and grass height. 


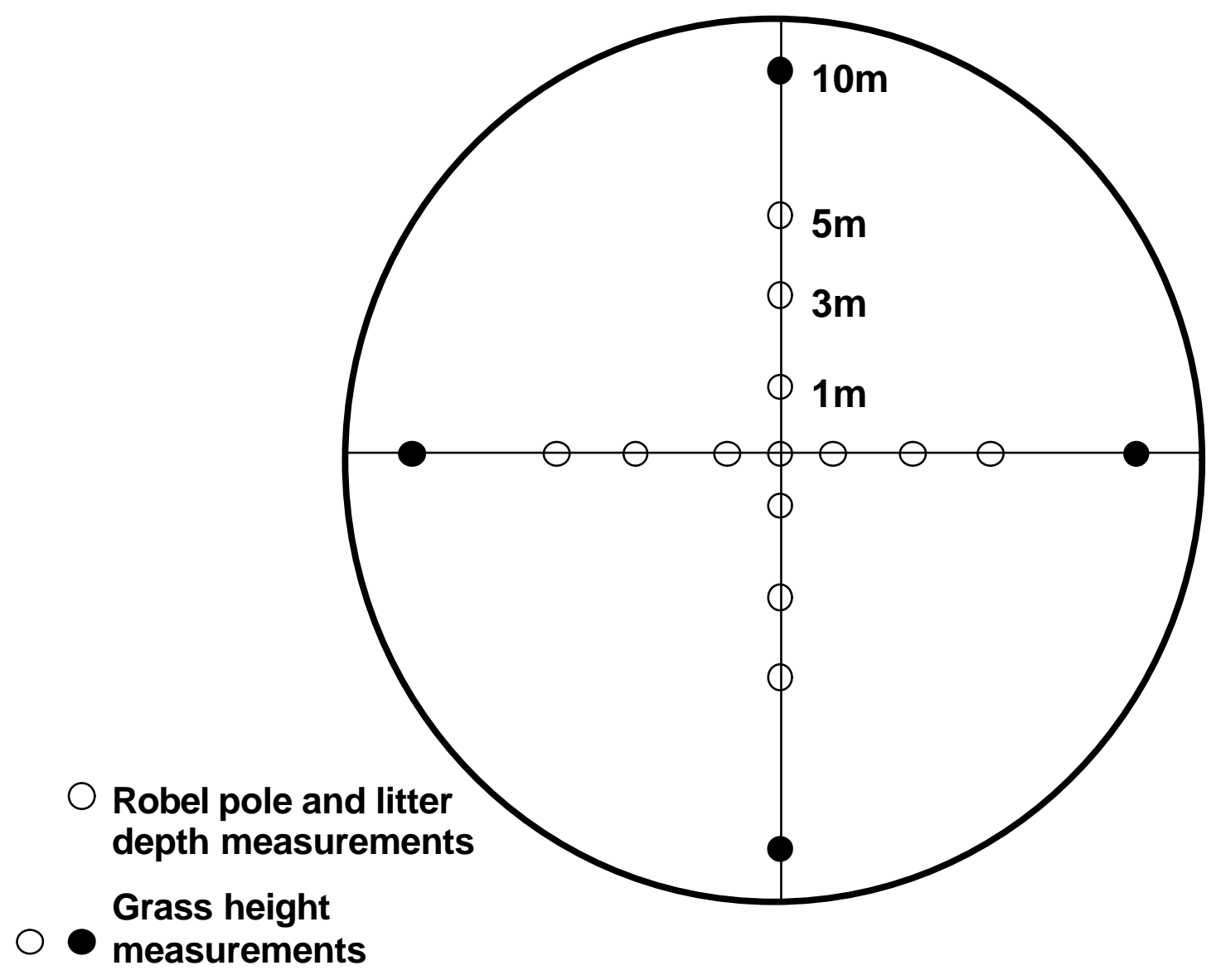

Figure 4. Sampling points on grassland vegetation subplot for vegetative cover and grass height measurements (Robel pole) and organic litter depth measurements. 


\section{CHAPTER 3}

Impact of Head-of-Hollow Valley Fill Construction on Streamside Salamanders in Southern West Virginia

[This chapter is formatted in the style of Journal of Herpetology.]

Abstract.-I quantified relative abundance of stream salamanders in southern West Virginia during 2001-2002 to examine impacts of head-of-hollow valley fill construction on these animals. Head-of-hollow valley fill construction can cover headwaters, first-order, second-order, and higher order reaches with excess spoil materials; valley fills in southern West Virginia are often hundreds of hectares in size. I sampled in streams below valley fills and in reference streams. In 2001, total captures were higher in 3 reference streams ( $R S ; N=389)$ than in 3 valley fill streams (VFS; $=289$ ). These data were not analyzed statistically because streams were not paired by order and structure. In 2002, I surveyed $3610-\mathrm{m}$ x 2-m stream transects, once in summer and once in fall; streams were paired by order and structure. In 2002, over two-thirds of 2343 total captures were from reference streams; larvae accounted for over $60 \%$ of captures. Adult densities in RS and VFS were 2.40 and 1.06 individuals $/ \mathrm{m}^{2}$, respectively, while larval densities were 4.91 and 2.29 individuals $/ \mathrm{m}^{2}$, respectively. Total salamanders (adults and larvae combined) and larval salamanders were more abundant in RS overall and in second-order reaches. Adult salamanders and adult Desmognathus salamander spp. had greater abundance in first-order RS than in first-order VFS. Percent cover of silt was greater in VFS than in RS both overall and in first-order reaches and is the most likely contributor to reduced abundance of salamanders in the VFS treatment. Second-order RS had more boulder cover than second -order VFS which may have favored total and larval salamanders and contributed to their higher abundance in RS. Other investigators conducted research on water chemistry of valley fill and reference streams in my study area and found elevated levels of metal and ion concentrations in VFS, which probably also had a significant effect on salamanders in these streams and may have negatively affected their abundance levels. Head-of-hollow valley fill construction appears to have significant negative effects on stream salamander populations due to alterations in habitat structure, water quality, and water chemistry in streams below these fills.

Mountain headwaters are home to many plethodontid salamander species in the eastern United States (Bishop, 1967). In headwaters, salamanders are often the dominant or most abundant vertebrate predators or the predators that contribute the most biomass (Burton and 
Likens, 1975; Hall et al., 1978; Murphy and Hall, 1981; Hairston, 1987). Amphibian monitoring programs use stream salamanders as potential indicators of headwater stream quality (Ohio Environmental Protection Agency, 2002) and densities of stream amphibians in general have been used as indicators of ecosystem stress (Welsh, Jr. and Ollivier, 1998; Lowe and Bolger, 2002). In general, however, there is a paucity of ecological research conducted on stream amphibians in the northeastern region of the United States (Lowe and Bolger 2002).

Stream plethodontids typically exhibit high densities and stable population sizes and age structures (Hairston, 1987; Burton and Likens, 1975; Welsh, Jr. and Ollivier, 1998; Jung et al., 2000, Rocco and Brooks, 2000). These traits, together with their porous skin that quickly reacts to changes in terrestrial and aquatic environmental quality (Jones, 1986; Blaustein and Wake, 1990; Shaffer, 1991) and their philopatry (Welsh, Jr. and Lind, 1992), make them ideal for use as bioindicators (Kucken et al., 1994; Welsh, Jr. and Ollivier, 1998). The limited mobility of salamanders due to their physiological constraints and anatomical characteristics (Green and Pauley, 1987) and the long lives of these animals make them even more desirable for use as bioindicators over the more traditionally used animals, fish and invertebrates, which may exhibit seasonal move ments (Welsh, Jr. and Ollivier, 1998). These traits, coupled with the small home ranges of salamanders, suggest that local abundances of stream salamanders should reflect impacts of disturbance (Corn and Bury, 1989).

Mountaintop Removal Mining Process

Mountaintop removal is a large-scale surface mining technique (Barnhisel et al., 2000) used in West Virginia, Virginia, Tennessee, Kentucky, and Pennsylvania (United States Environmental Protection Agency, 2000). The unconsolidated geological material resulting from overburden removal constitutes a much greater volume than the once consolidated material (United States Environmental Protection Agency, 2000). Not all overburden can be returned to the mountaintop; otherwise, long-term stability problems may stem from too steep of slopes (Sciulli et al., 1986; Bell et al., 1989; United States Environmental Protection Agency, 2000). Therefore, excess spoil is deposited into valleys near the active mine site, creating a valley fill (United States Environmental Protection Agency, 2000).

Head-of-hollow valley fills are positioned at the headwaters of watersheds (Daniels and Stewart, 2000). Dump trucks unload overburden into the valley from along the ridgeline. In this process, a natural segregation of large and small rocks occurs, with large, boulder-sized ones falling to the valley bottom and small rocks settling on top. Because mountaintop-mining 
disturbance encompasses a large area, reconstruction of landforms for complex head-of-thehollow valley fills may require reclamation of first-, second-, third-, and higher-order drainage basins (Toy and Black, 2000). It is common for valley fills in southern West Virginia to be hundreds of hectares in size (Daniels and Stewart, 2000) and to contain thousands of cubic meters of fill material (Plass, 2000).

\section{Past Research on Impacts of Mining and Related Effects on Herpetofauna}

Impacts of other methods of coal mining on herpetofauna have been documented (Riley, 1952, 1960; Myers and Klimstra, 1963; Redmond, 1980; Turner and Fowler, 1981; Gore, 1983; Fowler et al. 1985, Middelkoop et al., 1998). None of these studies focused on mountaintop removal mines and none were conducted in West Virginia. Some authors did not use standardized survey methods, did not analyze their results statistically, and / or conducted their work prior to the enactment of the Surface Mining Control and Reclamation Act of 1977 (SMCRA; Public Law 95-87, 1977). The SMCRA standardized coal mining and reclamation for the nation and imposed regulations on surface impacts of mining and water quality standards (Starnes and Gasper, 1995). Thus far, only 1 other study has examined effects of mountaintop removal mining on stream herpetofauna Hamilton (2002).

Hamilton (2002) compared mountaintop removal mining valley fill streams with reference streams in southern West Virginia to determine impacts on streamside salamander communities. She found a lower relative abundance of salamanders in 2 of 3 valley fill streams when compared to two reference streams. However, with increasing time since valley fill construction, streamside salamanders in a third valley fill stream appeared to reach abundance levels similar to that of reference streams. One of the 2 reference streams chosen for study by Hamilton (2002) had been impacted by surface mining approximately 50 years prior to her study. The mining activity may have impacted the stream salamander community in such a way that relative abundance during the time of her study may not have been characteristic of what was present prior to disturbance. This study did not examine habitat characteristics of study streams.

\section{Water Quality}

Several researchers have completed studies on water quality of streams impacted by mountaintop removal mining (United States Environmental Protection Agency, 2000; Bryant et al., 2002; Hedrick and Ras, 2002; Hartman et al., unpubl. data); results by Hedrick and Ras (2002) were not analyzed statistically. Three of these studies found elevated levels of specific conductance in valley fill streams (Bryant et al., 2002; Hedrick and Ras, 2002; Hartman et al., 
unpubl. data) and 2 discovered high levels of sulfate, hardness, and total dissolved solids in fill streams (Hedrick and Ras, 2002; Bryant et al., 2002). Meanwhile, both Hartman et al. (unpubl. data) and Bryant et al. (2002) reported high concentrations of calcium, magnesium, manganese, and potassium. Levels of chloride (Hedrick and Ras, 2002), sodium, copper, nickel, and iron (Hartman et al., unpubl. data), as well as selenium and nitrate / nitrite concentrations and acidity (Bryant et al., 2002) also were all found to be high in valley fill streams.

Mining activities often produce sediment that fills and coats stream substrate (Nelson et al., 1991). The steep slopes of the Appalachian coal region, where mountaintop removal mining is most common, generate the largest amount of sediment (Starnes, 1985). Sedimentation increases in severity when single watersheds contain multiple mines (Starnes, 1985). Running an extensive mountaintop mining operation may have effects similar to running multiple small mines within a watershed.

Most studies on the relation of water chemistry to amphibian diversity and abundance focused on anurans and / or amphibian species that occupy temporary pond habitats; relatively few studies have examined effects on plethodontid salamanders that reside in headwater streams, seeps, and springs (Freda et al., 1991). Many studies documented impacts of low pH on herpetofauna (e.g., Clark, 1986; Beattie and Tyler-Jones, 1992), a condition not usually found in streams affected by mountaintop removal mining. Acid mine drainage (AMD) is not a condition typically associated with mountaintop removal mining in southern West Virginia (J. Skousen, Extension Specialist on Land Reclamation and Professor of Soil Science at West Virginia University) because the coalfields of southern West Virginia have low sulphur content ( $1 \% \mathrm{~S}$ ), compared to coal from the northern part of the state, which can be up to $6 \%$ sulphur (Gerena, 2001). In the southern coalfields, pyrite exists in small, isolated pockets; thus, with proper overburden handling and placement, pyrite can be isolated and kept from water and air so that it does not become oxidized and produce acidic soil and water conditions (J. Skousen, Extension Specialist on Land Reclamation and Professor of Soil Science at West Virginia University).

Although mountaintop removal mining has been implemented for over 30 years in West Virginia and is used in several other states, the separate and synergistic effects of such largescale disruption to hydrologic regimes have only recently come under investigation. Disruption of aquatic habitats by mountaintop removal mining may affect entire watersheds (Starnes and Gasper, 1995). Aquatic impacts include direct loss or fragmentation of habitat, as well as alterations in habitat structure and water chemistry. The southern Appalachians exhibit 
extremely high diversity of salamander populations (Petranka, 1998); therefore, any impacts sustained by these stream salamander populations may be of regional significance. For these reasons and those previously mentioned, the watersheds below valley fills and any impacts sustained by them and their biotic components deserve considerable attention.

The first objective of this research was to determine if there were differences in relative abundance of stream salamanders between reference streams and streams impacted by head-ofhollow valley fill construction in a reclaimed mountaintop mining landscape in southern West Virginia. The second objective was to compare habitat characteristics between valley fill and reference streams to determine what habitat variables, if any, could be driving differences in salamander abundance.

\section{MATERIALS AND METHODS}

Study Sites.-Study areas were located on and near 3 mountaintop mines in southwestern West Virginia: Hobet 21, Cannelton, and Dal-Tex. These mines were located in Boone, Kanawha and Fayette, and Logan counties, and in Mud River and Little Coal River, Twentymile Creek, and Spruce Fork watersheds, respectively. There was considerable distance between mines (over a

hundred miles between Dal-Tex and Cannelton Mines) to provide geographical perspective (Hall et al., 1978). Study sites were located within the Allegheny Plateau physiographic province, which is characterized by moderate to strong relief and contains central hardwood forests (Strausbaugh and Core, 1977). Habitat types on the mines included reclaimed grasslands, reclaimed shrub / pole, and forest fragments with reclaimed habitats covering 2431, 1819, and 2180 ha (Balcerzak and Wood, 2003). In the region of my study sites, headwaters of streams are usually dominated by boulders and are fairly narrow. Further downstream, substrate becomes smaller and flow increases in velocity, particularly in higher-order reaches.

I sampled in 2 treatments: valley fill streams (VFS) and reference streams (RS). Valley fill streams were in forests that were bordered on at least 3 sides by reclaimed mine habitat (i.e. fragmented forest) and were located below head-of-hollow valley fills. In 2001, they included Big Horse Creek, Lavender Fork (both on Hobet 21 Mine), Rockhouse Creek (on Dal-Tex Mine), and Hughe's Fork (on Cannelton Mine). In 2002, I removed Lavender Fork from the study because it did not contain suitable habitat (e.g., predominance of cobble; see 2002 Study Design). Forest fragments were of a sufficient size (114 ha, 290 ha, and 58 ha) that fragment size would not have an effect on stream herpetofaunal populations. 
Reference streams were in intact forests that were not located on mine property and were not directly impacted by mountaintop removal mining. The intact forests of the region were relatively contiguous and were located within close proximity to the mines so that distance would not be a confounding factor in my study (Hall et al., 1978). In 2001, the RS were Spring Branch (near Hobet 21 Mine), Pigeonroost Branch (close to Dal-Tex Mine), and Ash Fork (near Cannelton Mine). In 2002, because Spring Branch had habitat characteristics too dissimilar from other streams, I replaced it with Bend Branch (near Dal-Tex Mine).

Both treatments were contained within mixed mesophytic forests with 60-80 year-old, second-growth, mature hardwoods. Overstory species included tuliptree (Liriodendron tulipifera), red and sugar maples (Acer rubrum and A. saccharum), American sycamore (Plantanus occidentalis), northern red, white, and black oaks (Quercus rubra, Q. alba, and $Q$. velutina); pignut, bitternut, and shagbark hickories (Carya glabra, C. cordiformis, and C. ovata); American beech (Fagus grandifolia), white ash (Fraxinus americana), and black birch (Betula lenta). Understory species (seedlings, saplings, poles) included black gum (Nyssa sylvatica), flowering dogwood (Cornus florida), ironwood (Carpinus caroliniana), spicebush (Lindera benzoin), and other common hardwood species, including the above-mentioned overstory species.

2001 Study Design.-I quantified herpetofaunal diversity and abundance by sampling 3 VFS and 3 RS once per month in May, June, and August-October. I added a fourth VFS (Rockhouse Creek) and sampled it in September and October. I sampled different 35-m segments in each stream each month. By moving down and sampling new, adjacent stream segments, my intention was to sample as much of the entire length of each stream as possible.

I classified each segment sampled by stream order (intermittent, first-order, second-order, or third-order) and by predominant structures. Stream order was determined from the following definitions from the Federal Interagency Stream Restoration Working Group (1998; pages 16; 25-26). "Intermittent streams flow only during certain times of the year. Seasonal flow in an intermittent stream usually lasts longer than 30 days per year." "The uppermost channels in a drainage network (i.e., headwater channels with no upstream tributaries) are designated as firstorder streams down to their first confluence. A second-order stream is formed below the confluence of 2 first-order channels. Third-order streams are created when 2 second-order channels join, and so on." 
Because creation of valley fills involves the burial of streambeds with large boulders, it is impossible to survey the first- and second-order stream sections that existed prior to mining. For example, coal removal and its associated filling, cons truction, and drainage installation affected over $30 \mathrm{~km}$ of Big Horse Creek. Approximately $20 \mathrm{~km}$ of first order streams and roughly $10 \mathrm{~km}$ of second order streams were impacted from filling activities, construction and drainage installation, and mineral removal (J. McDaniel, pers. comm.). In Rockhouse Creek, nearly $4 \mathrm{~km}$ of first-order streams and approximately $1.5 \mathrm{~km}$ of second-order streams were similarly impacted (J. McDaniel, pers. comm.). Therefore, for VFS, I considered first-order stream sections to be the furthest upstream portion of the valley fills from which water was free flowing and not overlain with riprap.

I used sampling methods similar to those of Crump and Scott, Jr. (1994). I turned over all cobble-sized rocks (65-256 mm; Jung, 2002) and coarse woody debris (CWD) in the stream channel and up to 1-m from the edge of the stream and checked under them for herpetofauna. I kept a count of all rocks and CWD inspected during the sample, with the exception of cover objects that clouded the water with bottom substrate upon lifting (Table 1). I recorded sampling time in person minutes, herpetofaunal species captured, length of salamanders from snout to anterior portion of vent $(\mathrm{cm}$; Fraser, 1974) and length $(\mathrm{cm})$, width $(\mathrm{cm})$, and type of substrate (e.g., rock) under which the animal was found. Person minutes are the sum total spent searching by each person; if 30 minutes was spent searching by 4 people, then the search time in person minutes would be 120 minutes. I did not identify G. porphyriticus to subspecies level (G. p. porphyriticus, Northern Spring Salamander, or G. p. duryi, Kentucky Spring Salamander). I toeclipped individuals to identify recaptures. After the 2001 field season, I refined my stream search study methods to increase sampling efficiency and statistical power.

In addition to stream searching, I placed 3 leaf litter bags in each stream and checked them monthly (June to October) to target capture of larval and juvenile salamanders. My methods followed those of Pauley and Little (1998), with slight modification (e.g., materials used in closing and cinching off bags). I cut plastic netting with $3-4 \mathrm{~cm}$ mesh size into $45-50 \mathrm{~cm}$ x $30 \mathrm{~cm}$ sections and stacked leaf litter, moss, and small CWD onto it. I then folded over the netting, creating a bag-like compartment, and cinched off the ends using cable ties and the tops using binder clips. I positioned bags in pools within the stream and anchored them down using rocks. Once each month, I emptied contents of leaf litter bags into a basin and searched through them for salamanders. 
Leaf litter bags were largely unsuccessful due to water recession or flooding. I used rocks to submerge and anchor bags in pools (T. Pauley, pers. comm.) in September of 2001; rocks were large enough to maintain the bags in place, but not so large as to bury the bags. This method proved to be successful because I obtained larval salamanders in a few bags when I checked them in October.

I planned to use leaf litter bags in 2002 by placing them within each $10 \mathrm{~m} \times 2 \mathrm{~m}$ stream segment centered on a pool and checking them during the summer and fall sampling months (see 2002 Study Design), but I ran short on time and so abandoned this technique. Recently, Chambers and Droege (2002) and Waldron et al. (2003) recommended that leaf litter bags not be used to index salamander populations because they observed a high relative amount of variation in number of individuals captured using this technique.

2002 Study Design.-I sampled 3 streams within each treatment (Figure 1). Within each stream, I sampled 1 first-order and 1 second-order portion of the stream. Within each order, I established $310 \mathrm{~m} \times 2 \mathrm{~m}$ transects, thus yielding 36 transects. I sampled all transects in summer (June, July, August) of 2002 and then again in fall (October, November) of 2002.

I quantified streamside salamander abundance with standardized stream search sampling techniques that closely modeled the Northeast Amphibian Research and Monitoring Initiative (ARMI) protocol of the United States Geological Survey (Jung 2002). I selected transects comprised mainly of cobble (Jung, 2002). For each stream and order, I attempted to center 2 transects on a riffle and a third transect on a pool (Figure 1). However, because I was unable to find 2 suitable transects that were centered on riffles in $1 \mathrm{RS}$, I established 2 transects centered on pools instead, and only 1 centered on a riffle. I did not attempt to standardize size or percent composition of mesohabitat (a collective term for different stream habitat types, such as riffle or pool; see Table 3) of stream transects because physical habitat of streams readily transforms (Power et al., 1988). Therefore, selecting reaches uniform in mesohabitat and cover proportion would have been difficult, if not impossible. I centered the 10-m length of each transect on the land / water interface; the 2-m width included $1 \mathrm{~m}$ out into the water and $1 \mathrm{~m}$ up on land (Jung, 2002).

I checked under all rocks and CWD with minimum lengths and widths of $65 \mathrm{~mm}$ for streamside salamanders within each transect (Jung 2002). I used aquarium dip nets to scoop under each cover object sampled within the water to target capture of larval salamanders and to secure adult salamanders found on land or in water. 
During each transect search, I placed each individual captured in a resealable bag and situated it in a shaded area out of the transect confines (Jung 2002). I supplied enough water in bags with adult salamanders so that their skin stayed moist, but so that they did not drown. I puffed bags up with air so that no individuals were stuck between the 2 sides of the resealable bags and filled bags containing larval salamanders with water, allowing them to be completely submerged. I did not reuse bags at other stream transects or within the same transect from summer to fall to minimize the potential for disease transfer.

I made 2 passes during each transect search. After each pass, I identified adults to species level and when possible, larvae to genus or species level; I recorded age classes for each capture. When possible, I identified to genus level adults that quickly escaped to burrows or water upon substrate lifting. As in 2001, I did not identify G. porphyriticus to subspecies level.

After each pass, I also measured and recorded total length $(\mathrm{mm})$ and length from snout to anterior portion of vent (mm) of adults (Fraser, 1974). For larvae, I recorded total length (mm) and, if the vent was easily observed, snout to anterior portion of vent (mm; Fraser, 1974). I noted type (e.g., rock) and position (e.g., in water or on shore) of substrate under which I found the animal. After measuring, I transferred adults to a large plastic container containing moist leaf litter and placed larvae in an open container of stream water; I positioned both container types in the shade (Jung, 2002). I also recorded search time in person minutes of each pass (Jung 2002).

At the beginning (downstream; $0 \mathrm{~m}$ ), middle (5 m), and end (upstream; $10 \mathrm{~m}$ ) of each transect, I measured the following variables: wet stream width $(\mathrm{cm})($ Table 3$)$, water depth $(\mathrm{cm})$, air temperature $1-\mathrm{m}$ above the water $\left({ }^{\circ} \mathrm{C}\right)$ and water temperature $\left({ }^{\circ} \mathrm{C}\right) 2 \mathrm{~cm}$ below the water surface (Jung, 2002). I also recorded sky and Beaufort scale wind codes (Table 3), date of last precipitation, and presence or absence of fish, crayfish, and aquatic invertebrates. If the sky code was 6,7 , or 8 , or if the wind code was 6 or 7 , I did not conduct a survey.

At each transect in the fall sampling season, I measured transect gradient from upstream to downstream endpoints, moist stream width, bankfull width, universal transverse mercator (UTM) north and east upstream coordinates, proportion of predominant mesohabitat, and proportion of cover within each transect (Table 3); proportions were estimated visually using a bird's-eye view (Jung, 2002). Bankfull discharge shapes stream channels and is defined as "that water discharged when stream water just begins to overflow into the active floodplain" (Wolman 
and Leopold, 1957). I measured bankfull width to gain some indication of what the past flows of each stream may have been like.

Predominant mesohabitat included the following categories: dry, moist, seep, pool, riffle, or run; totals for each transect summed to $100 \%$ (Jung, 2002). Cover proportion was also summed to $100 \%$ for each transect and included the following categories: sand, gravel, pebble, cobble, boulders, bedrock, silt, detritus, clay / hardpan, muck, and artificial (e.g., pipe). Cover by fine sediment was calculated from the sum of cover by both silt and sand. I deemed cobble to be the most important cover type because Jung (2002) recommended basing transect choice on predominance of cobble. Therefore, I also estimated "after-cobble." Furthermore, I estimated "after-boulder," as I speculated that the area offered by this would be useful as refuge for sala manders. After-cobble and after-boulder were the total percent cover of cobble and boulder, respectively, observed without consideration for their cover by detritus. I determined these values at the end of my search when I was most familiar with the substrate composite. By collecting data on habitat characteristics, I hoped to interpret any differences in relative abundance between treatments and to identify any habitat variables that may be important to stream salamanders.

Statistical Analysis 2001.-I did not analyze statistically any data from 2001 stream surveys because I did not pair sample sites by stream order, nor did I select sites based on predominant mesohabitat or cover. Therefore, sampling points within and between treatments were too dissimilar to compare. Means are presented, however, because these data do provide some insight into relative abundance of salamanders within streams on the study sites. Statistical Analysis 2002.-I used analysis of variance (ANOVA) to examine differences in relative abundance 1) between treatments overall and within each order and 2) relative to order and season. The ANOVA model that compared relative abundance between treatments included relative abundance as the dependent variable and treatment, order, season, and interactions between each of these variables as independent variables. To examine differences in relative abundance between treatments within each order, the ANOVA model included relative abundance as the dependent variable and treatment, season, and the interaction between treatment and season as the independent variables. The error term for each model was stream within treatment. Orders within streams were the experimental units.

Relative abundance was calculated by totaling the number of individuals captured on the 3 transects within a stream order for each treatment. I opted to measure relative abundance 
instead of absolute abundance for the sake of sampling effort. Rather than searching each transect until I found no more salamanders within a survey area, I used a standardized search technique suitable for comparing relative abundances among treatments. I examined relative abundance for total salamanders (adults and larvae combined), adult salamanders, larval salamanders, and adult Desmognathus salamander spp.

Total Salamanders.-For total salamanders, I log transformed relative abundance when comparing between treatments. In the ANOVA that compared relative abundance between treatments within second-order reaches, I reduced kurtosis by subtracting 30 from relative abundance and then log transformed this value.

Adult Salamanders.-I transformed relative abundance of adult salamanders using $\mathrm{X}^{-1}$ in the ANOVA that compared relative abundance between treatments. I log transformed their relative abundance in the ANOVAs that compared relative abundance between treatments within firstand second-order reaches.

Adult Desmognathus Salamander spp.-I was unsuccessful in homogenizing variances using any transformation in the ANOVA that compared relative abundance of adult Desmognathus salamander spp. between treatments, and so I ranked relative abundance (PROC RANK; SAS Institute, 1990) and ran the ANOVA on the ranks of those data (PROC GLM; SAS Institute, 1990). This procedure functions like a Kruskall-Wallis non-parametric test. However, it permits the use of complex models and unequal sample sizes between treatments (Sokal and Rohlf, 1995). In the ANOVA that compared relative abundance of adult Desmognathus salamander spp. in first-order reaches between treatments, I used a log transformation on relative abundance, while in the ANOVA comparing relative abundance within second-order reaches, I used a square root transformation on the dependent variable.

Larval Salamanders.-I used a square root transformation on larval salamander relative abundance in the ANOVA that compared relative abundance between treatments. In the ANOVA that compared relative abundance within first-order reaches, no transformations allowed the variances to homogenize, so I ranked the data and ran the ANOVA on the ranks (see Adult Desmognathus salamander spp. section) (Sokal and Rohlf, 1995). I log transformed relative abundance in the ANOVA that compared relative abundance within second-order reaches.

Interactions for Relative Abundance.- If I observed a significant interaction between treatment and season, I compared relative abundance between treatments within each season separately. 
To avoid a reduction in sample size and power and an inflation in mean square error, I used 2 contrast statements to make the 2 within-treatment comparisons (Cody and Smith, 1997). The first contrast compared summer to fall for VFS and the second compared these seasons for RS. Habitat Variables.-I compared habitat characteristics between treatments using ANOVA. All mesohabitat and cover variables were dependent variables, while treatment, order, and the interaction between treatment and order were the independent variables. Season was not included as an independent variable because I did not collect data on all habitat variables in the summer (e.g., mesohabitat data were collected only in the fall). The error term for this model was stream within treatment. To examine differences in habitat characteristics between treatments within each order, the ANOVA model included all mesohabitat and cover variables as dependent variables and treatment as the independent variable.

I used linear regression to examine the relationship between habitat variables and relative abundance of total salamanders, adult salamanders, larval salamanders, and adult Desmognathus salamander spp. The models had relative abundance as the dependent variable and treatment, order, the interaction between treatment and order, and 1 of the 19 habitat variables for independent variables. Orders within each stream were the experimental units. Again, I did not consider season in my regression models because I sampled most of the habitat data only in the fall.

I assigned values of 1 and -1 to treatment variables (VFS, RS) and to order variables (first-order, second-order). This allowed me to use these variables in PROC REG even though they are categorical variables (G. Seidel, pers. comm.). Thus, with this numerical classification, these variables and the interaction between them were expressed as a set of orthogonal contrasts and served as blocking factors (G. Seidel, pers. comm.). I could not include all habitat variables into 1 model because I had too many independent variables and not enough data points. To control the experimentwise error rate due to running several linear regressions, I made a Bonferroni adjustment by taking my chosen á level and dividing it by the number of regression models $(0.10 / 19=0.0053)($ Schlotzhauer and Littell, 1997).

I used SAS 8.1 (SAS Institute, 2000) for data analyses. I used the Shapiro-Wilk test for normality and Levene's test for homogeneity of variance. A $P$-value of 0.10 was considered significant for statistical tests other than the regression models, which used a $P$-value of 0.0053 . Use of a higher alpha level is justified when researching conservation issues to avoid making a type II error (Askins et al. 1990; Caughley and Gunn 1995). 


\section{RESULTS}

2001 Data.-In 2001, I captured 678 stream herpetofauna of 15 species in stream surveys, 13 species in VFS and 10 in RS (Table 4). Total captures were higher in RS $(n=389)$ than in VFS $(n=289$; Table 5), although I sampled 2 extra stream segments in VFS (Table 6). Salamanders comprised $97 \%$ of total captures and were the only taxa included in abundance calculations per stream segment. Second-order VFS had the highest $(68.5 \pm 7.5)$ and lowest $(1.8 \pm 0.97)$ means of salamanders per stream segment (Table 6).

Using leaf litter bags, I found 20 larvae in RS and 3 in VFS. Of those captured in RS, 9 were Northern Dusky Salamanders (Desmognathus fuscus), 1 was a Southern Two-lined Salamander (Eurycea cirrigera) and the remaining 10 could not be identified. In the VFS, 1 larvae was a Southern Two-lined Salamander and the other 2 were unidentifiable. 2002 Data.-I had 2343 captures of stream salamanders in 2002 (Table 7). Reference streams had over 2 times the number of captures $(\mathrm{N}=1563)$ as VFS $(\mathrm{N}=780)$. Larvae represented $63.1 \%$ of total captures in RS and $67.3 \%$ in VFS. I captured 3 species in both RS and VFS: Northern Dusky Salamander, Seal Salamander (D. monticola), and Southern Two-lined Salamander. I captured 1 adult Spring Salamander (Gyrinophilus porphyriticus) in RS and 1 adult Northern Red Salamander (Pseudotriton r. ruber) in VFS. In RS, Desmognathus spp. constituted $94.7 \%$ of adult captures $(\mathrm{N}=570)$ and $93.3 \%$ in VFS $(\mathrm{N}=254)$. Few adult Southern Two-lined Salamanders were captured in RS $(\mathrm{N}=29)$ and VFS $(\mathrm{N}=16)$.

I captured several other herpetofaunal species that I excluded from statistical analyses. In RS, I captured 1 each of the following: Common Watersnake (Nerodia s. sipedon), Northern Green Frog (Rana clamitans melanota), and Eastern Red-backed Salamander (Plethodon cinereus). In VFS, I captured 1 each of the following: Pickerel Frog (R. palustris) and American Bullfrog (R. catesbeiana). I captured 1 Rana spp. in each treatment; both escaped before I was able to identify them to species.

Total Salamanders.-Relative abundance of total salamanders was significantly higher in RS than in VFS (Table 8). Relative abundance did not differ by order $(\mathrm{F}=0.60, P=0.48)$ or season $(\mathrm{F}=$ $1.19, P=0.34)$. There were no interaction effects between treatment and order $(\mathrm{F}=1.53, P=$ $0.28)$ or between treatment and season $(\mathrm{F}=0.80, P=0.42)$.

I found no differences in relative abundance of total salamanders between treatments in first-order streams, but in second-order streams, relative abundance was higher in RS (Table 8). 
In first-order streams, relative abundance was not different between seasons $(\mathrm{F}=0.18, P=0.69)$ and there was no treatment by season interaction $(\mathrm{F}=0.08, P=0.79)$. Similarly, in second-order reaches, relative abundance was not different between seasons $(\mathrm{F}=3.56, P=0.13)$ and there was no treatment by season interaction $(\mathrm{F}=1.74, P=0.26)$.

Adult Salamanders.-Relative abundance of adult salamanders was not significantly different between treatments (Table 8) and no differences were found relative to order $(\mathrm{F}=1.65, P=0.27)$ or season $(\mathrm{F}=0.05, P=0.84)$. No interaction effect occurred between treatment and order $(\mathrm{F}=$ $0.15, P=0.72)$ or between treatment and season $(\mathrm{F}=2.82, P=0.17)$.

I found significantly higher relative abundance in RS than in VFS in first-order reaches, but there were no differences in second-order reaches (Table 8). In first-order streams, relative abundance was not different among seasons $(\mathrm{F}=0.41, P=0.56)$ and there was no treatment by season interaction $(\mathrm{F}=0.28, P=0.62)$. In second-order streams, relative abundance also did not differ among seasons $(\mathrm{F}=1.73, P=0.26)$. In second-order reaches, I analyzed relative abundance separately by seasons because of a significant interaction between season and treatment $(\mathrm{F}=5.38, P=0.08)$. In summer, RS supported $155 \%$ more adult salamanders than VFS (Table 8), while fall relative abundance was $42 \%$ more in RS than in VFS. However, I found no significant difference between treatments in summer $(\mathrm{F}=2.25, P=0.21)$ or in fall $(\mathrm{F}=$ $0.36, P=0.58)$. Comparing seasons within treatments, I found a significant decrease of $44 \%$ from summer to fall in $\mathrm{RS}(\mathrm{F}=9.66, \mathrm{P}=0.04)$, but no significant change ( $\sim \%$ decrease) in VFS $(\mathrm{F}=0.07, P=0.81)$.

Adult Desmognathus salamander spp.-Relative abundance of adult Desmognathus salamander spp. was not significantly different between treatments (Table 8$)$ or seasons $(\mathrm{F}=1.91, P=0.24)$. Relative abundance was greater in first order reaches $(\mathrm{F}=5.44, \mathrm{P}=0.08)$ than in second order reaches within treatments; it was $69 \%$ greater in first-order RS and $21 \%$ greater in first-order VFS. I found no interaction between treatment and order $(\mathrm{F}=2.75, P=0.17)$, nor between treatment and season $(\mathrm{F}=0.92, P=0.39)$.

In first order reaches, I found a higher relative abundance of adult Desmognathus salamander spp. in RS than in VFS (Table 8), but no season $(\mathrm{F}=0.35, P=0.59)$ or season by treatment $(\mathrm{F}=0.31, P=0.61)$ effects. In second-order reaches, I analyzed relative abundance separately by seasons because of a significant interaction between season and treatment $(\mathrm{F}=$ 9.98, $P=0.03$ ). In summer, RS supported $152 \%$ more adult Desmognathus salamander spp. than VFS (Table 8), while fall relative abundance was $18 \%$ greater in RS. However, I found no 
significant difference between treatments in summer $(\mathrm{F}=2.09, P=0.22)$ or in fall $(\mathrm{F}=0.09, P=$ 0.78). Comparing seasons within treatments, I found a significant decrease of $56 \%$ from summer to fall in RS (F=18.39, $P=0.01)$, but no significant change (5\% decrease) in VFS $(\mathrm{F}=0.03, P$ $=0.87)$.

Larval Salamanders.-Relative abundance of larval salamanders was significantly higher in RS than in VFS (Table 8). Larval salamander relative abundance did not differ among orders ( $\mathrm{F}=$ $0.04, P=0.85)$ or seasons $(\mathrm{F}=1.35, P=0.31)$. Interactions between treatment and order $(\mathrm{F}=$ 2.20, $P=0.21)$ and between treatment and season $(\mathrm{F}=0.65, P=0.47)$ were not significant.

In first-order reaches, relative abundance of larval salamanders was not different between treatments (Table 8$)$ or seasons $(\mathrm{F}=1.50, P=0.29)$ and there was no treatment by season interaction $(\mathrm{F}=1.50, P=0.29)$. In second-order reaches, however larval salamanders were significantly more abundant in RS than in VFS. I found no seasonal differences $(\mathrm{F}=2.87, P=$ $0.17)$ and no treatment by season interaction $(\mathrm{F}=1.49, P=0.29)$.

Habitat Characteristics.-Percent cover of silt was significantly higher in VFS than in RS overall and in VFS first-order reaches; percent cover of fine sediment was also significantly higher in first-order VFS than in RS (Table 9). Wet stream width $(\mathrm{F}=16.10, P=0.02)$ and moist stream width $(\mathrm{F}=19.14, P=0.01)$ were different between orders. Second-order reaches had wet stream widths $41 \%$ wider than first-order reaches in RS and $45 \%$ wider in VFS. Second-order reaches also had moist stream widths $46 \%$ wider than first-order reaches in RS and $22 \%$ wider in VFS.

There was a significant interaction between order and treatment for gradient $(\mathrm{F}=4.37, P$ $=0.10$ ). However, I found no significant difference in gradient between treatments in first- or second-order reaches (Table 9). Comparing orders within treatments, there was a significant difference between orders in $\mathrm{RS}(\mathrm{F}=8.18, P=0.05)$, but there were no differences in VFS $(\mathrm{F}=$ $0.01, P=0.93)$. The approximate difference between orders in RS was $1.6 \%$ in RS, with firstorder reaches having a 3\% mean gradient. Both first- and second-order reaches in VFS had gradient means of approximately $1.6 \%$.

The overall difference in percent cover of boulders approached significance, with a greater percent cover in RS than in VFS and in second-order reaches. Boulder cover was significantly higher in RS than in VFS (Table 9). For all other habitat variables, there were no significant differences between treatments, significant effects due to order, or order by treatment interactions. 
Percent cover by fine sediment was inversely associated relative abundance of total stream salamanders $\left(\mathrm{R}^{2}=0.86, \mathrm{~F}=6.39, P=0.03\right)$, adults $\left(\mathrm{R}^{2}=0.72, \mathrm{~F}=4.53, P=0.04\right)$, and adult Desmognathus salamander spp. $\left(\mathrm{R}^{2}=0.75, \mathrm{~F}=5.18, P=0.03\right.$; Table 10). Percent gravel cover was inversely related to adult salamander $\left(\mathrm{R}^{2}=0.85, \mathrm{~F}=10.20, P=0.005\right)$ and adult Desmognathus salamander spp. $\left(\mathrm{R}^{2}=0.87, \mathrm{~F}=12.12, P=0.003\right)$ relative abundance. Percent sand cover was also inversely related to adult salamander $\left(\mathrm{R}^{2}=0.93, \mathrm{~F}=22.42, P=0.0004\right)$ and adult Desmognathus salamander spp. $\left(\mathrm{R}^{2}=0.93, \mathrm{~F}=23.77, P=0.0004\right)$ relative abundance. Larval salamander relative abundance was positively related to percent cover of cobble $\left(\mathrm{R}^{2}=\right.$ $0.87, \mathrm{~F}=11.93, P=0.003)$.

\section{DISCUSSION}

Species assemblages of stream salamanders in states bordering West Virginia were similar to those found on my study areas. In southwestern Pennsylvania, Krzysik (1979) documented Seal Salamanders, Northern Dusky Salamanders, and Allegheny Mountain Dusky Salamanders (Desmognathus ochrophaeus) as the most abundant streambank species captured, while he encountered Northern Spring Salamanders and Northern Red Salamanders infrequently and described them as uncommon and rare, respectively. Rocco and Brooks (2000) captured 7 species of stream salamanders in Pennsylvania. Northern Two-lined Salamanders (Eurycea bislineata) accounted for 52\% of all captured individuals, followed by Allegheny Mountain Dusky Salamanders (22\% of all captures) and Northern Dusky Salamanders (15\%). The other $11 \%$ consisted of Seal Salamanders, Northern Red Salamanders, Northern Spring Salamanders, and Long-tailed Salamanders (Eurycea l. longicauda). Mitchell (1999) found Seal Salamanders, Northern Two-lined Salamanders, and Northern Spring Salamanders to comprise the majority of captures in his study of watersheds in Virginia.

Petranka (1998) made the general statement that in optimal habitats larval densities in streams frequently exceed 2-3 individuals $/ \mathrm{m}^{2}$ and adult densities in streambeds or on forest floors may surpass 1-2 individuals $/ \mathrm{m}^{2}$. In my study, data from VFS fell within the ranges reported by Petranka (1998) for both age groups, while data from RS exceeded the ranges in each age group. Densities in RS were double those of VFS for both age classes. While the ANOVA models did not always detect a statistically significant difference in relative abundance between treatments, abundance trends were similar for every analysis. The reference streams always supported a higher relative abundance of stream salamanders. 
Upper portions of first-order streams are often lost to valley fills (United States Environmental Protection Agency, 2003). With large or complex head-of-hollow valley fills, first-, second-, third-, and higher-order drainage basins may be filled and reconstructed (Toy and Black, 2000). In first-order reaches of RS, I found a greater relative abundance of adult salamanders and adult Desmognathus salamander spp., while second-order reaches of RS supported a higher relative abundance of both total salamanders and larval salamanders than VFS. These results illustrate the importance of maintaining first- and second-order portions of watersheds as natural habitats in southern West Virginia; their salamander densities indicate that these habitats are of the highest quality.

Although the valley fill streams on my study areas maintained flow year-round, this does not occur for all streams below valley fills. Powell (2000a) cited inadequate groundwater supply as a major limitation in maintaining base flow of streams impacted by mining, which restricts habitation by aquatic biota in first- and second-order streams. My study suggests that even with adequate flow, streams below valley fills do not support populations of salamanders in the abundances found in streams not impacted by valley fills. Similarly, Hamilton (2002) found a lower relative abundance of salamanders in 2 of 3 valley fill streams compared to reference streams in southern West Virginia.

Percent silt cover was twice as high in VFS than in RS (28.3\% versus $13.5 \%$, respectively) overall and over 4 times higher in first-order reaches (28.9\% versus $7 \%)$. Therefore, silt cover may have contributed to the overall lower abundance of total salamanders and larval salamanders in VFS and the lower relative abundance of adult and adult Desmognathus salamander spp. found in first-order reaches of VFS. Although sand cover did not differ between treatments, it was inversely related to relative abundance of adult stream salamanders and adult Desmognathus salamander spp. Fine sediment percent cover, which represents both silt and sand, negatively affected both adult salamander groups as well as total salamanders and it was higher in first-order VFS than RS. Redmond (1980) found that elevated silt and sand concentrations prohibited occupation of coal mining impacted streams by Black Mountain Dusky Salamanders, a Desmognathus sp. Sand can negatively affect a suite of salamander population factors, including species richness, frequency of occurrence, biomass (Corn and Bury, 1989), and reproductive success (Bruce, 1978). It also can reduce habitat quality and prey availability (Hall et al., 1978; Murphy and Hall, 1981; Hawkins et al., 1983; 
Corn and Bury, 1989; Lowe and Bolger, 2002). Intolerance of sand also influenced salamander distribution in streams studied by Hawkins et al. (1983) and Krzysik (1979).

Hartman et al. (unpubl. data) found no difference in fine sediment levels in first-order headwaters between streams located below valley fills and reference streams. They defined fine sediment to be less than $0.5 \mathrm{~mm}$, which could include both silt and sand, according to the classification system that I used (Jung, 2002). Hartman et al. (unpubl. data) suspected that there was an initial spike in sediment during and immediately following valley fill construction from placement of overburden into streams, but that over time, the sediment dissipated. When I combined silt and sand percent cover into 1 variable (fine sediment), percent cover was higher in first-order RS than first-order VFS, but there were no overall differences.

While I found no difference in gradient between treatments, and gradient was not a good predictor of stream salamander relative abundance, it was steeper in first- than in second-order RS streams. A low gradient in streams exacerbates problems of sedimentation, as fine particles tend to remain stationary (Hall et al., 1978; Hawkins et al., 1983; Corn and Bury, 1989). In my study, first-order reference reaches generally had less silt cover than second-order. Gradient significantly affected stream salamander presence, biomass, and populations in other studies (Hall et al., 1978; Hawkins et al., 1983; Corn and Bury, 1989).

I found a negative relationship between relative abundances of adult salamander and adult Desmognathus salamander spp. and percent cover of gravel, suggesting that salamander abundance decreased as gravel cover increased. In contrast, other researchers found gravel to be a favored substrate for stream salamanders. It was among the substrates preferred by Black Mountain Dusky Salamanders and Northern Dusky Salamanders (Redmond, 1980) and it was 1 of the best predictors of Pacific Giant Salamander abundance in streams studied by Welsh, Jr. and Ollivier (1998). Welsh, Jr. and Ollivier (1998) defined gravel using the same terms that I used, but Redmond (1980) did not specify how he classified substrate particles mentioned in his study, which included silt, sand, small gravel, coarse gravel, gravel, and large rock.

I also observed a positive relationship between relative abundance of larval salamanders and percent cover of cobble that approached significance. Likewise, numerous other researchers found several stream salamander species to prefer cobble-sized rocks for refuge (Corn and Bury, 1989; Welsh, Jr. and Ollivier, 1998).

In second-order reaches, boulder cover was significantly higher in RS than in VFS. Overall, differences in boulder cover approached significance with higher cover in RS than in 
VFS. Boulders serve as important habitat components for stream salamanders by providing pool habitat in high gradient streams (Murphy and Hall, 1981). Because pools may retain water during seasonal drying when riffles cannot, larval inhabitants in such pools may have increased survivorship (Holomuzki, 1991). In fishless pools, larvae of Streamside Salamanders (Ambystoma barbouri) are often abundant (Sih et al., 1992) and in pools with fish, presence of boulders and other rocks may serve to increase the survivability of larvae until transformation (Petranka, 1998). In second-order streams and overall, relative abundance of total salamanders and larvae were higher in RS. Boulder cover differed by just roughly $4 \%$ in second-order streams and 3\% overall and boulder cover was not a good predictor of relative abundance for any category of salamander (which may be due to the conservative alpha used in the Bonferroni adjustment). However, this difference may have been enough to favor stream habitation by total salamanders and larvae in second-order streams and overall in RS, or perhaps overall lower boulder cover coupled with higher levels of silt in streams below valley fills drove the abundance levels down in VFS.

Perhaps if I had collected data on the layered strata within the stream transects I could have explained more of the variation in results. By recording only a bird's eye view of cover in each transect, which is commonly done in stream substrate sampling, the data only reflect what is present on the uppermost strata and all variables summed together must equal $100 \%$. Using the bird's eye method, sand may cover an entire stream bottom, but if it is entirely overlain with cobble, it would be recorded as $0 \%$. Recording layered data would allow the investigator to record percent coverage for each habitat variable without consideration to other habitat variables; therefore, all variables summed together could be in excess of $100 \%$. The assumption made when just recording bird's eye view data is that the uppermost substrate is most important to stream salamanders and is adequate for determining habitat quality and predicting relative abundance. The uppermost substrate certainly has its place in helping to determine habitat quality. For example, the coating of substrate with sand or silt renders it less suitable; such conditions would be highlighted using the bird's eye me thod. However, other suitable cover may be available below the silt (cobble, boulders, etc.) and is equally noteworthy. Lowe and Bolger (2002) addressed similar concerns by recording "embedded cover," which they defined as those objects that had "visible vertical surfaces . . . buried in either silt or sand (modified from Welsh et al. 1997)." 
Water quality has significant effects on amphibians (see Chap 1 for review). The exact effects are difficult to determine, as they vary among and within species and in relation to the combination and concentration of chemical components, among other factors. Although I was unable to collect water quality data simultaneously with my salamander sampling, work done in valley fill and reference streams by Hedrick and Ras (2002), Bryant et al. (2002), and Hartman et al. (unpubl. data) are helpful in interpreting my results. Their reports of significant alterations in water chemistry below valley fills, coupled with my findings of increased sedimentation in VFS are the most probable direct causes of reduced salamander densities in VFS.

Many studies have examined the effects of low $\mathrm{pH}$ and acidic conditions on amphibians (see Chapter 1 for review), but more work on impacts of alkaline mine drainage on stream salamanders is greatly needed. While valley fill streams have high metal and cation concentrations, they also contain high $\mathrm{pH}$ and high alkalinity. Mean $\mathrm{pH}$ levels reported by Hartman et al. (unpubl. data) for valley fill streams (7.2) and reference streams (7.7) are not within the range found harmful to amphibians (see reviews by Freda, 1986 and Pierce, 1993). Five salamander species preferred an alkaline $\mathrm{pH}$ of 7.7 over acidic substrates with $\mathrm{pHs}$ of 5.5 (Mushinsky 1975), which indicates that both valley fill streams and reference streams contain $\mathrm{pH}$ levels suitable for occupancy by salamanders.

My study was of relatively short duration so I was not able to assess year-to-year variation. However, natural fluctuations are of less concern with stream plethodontids because they are known to have stable population sizes and age structures (Hairston, 1987; Burton and Likens, 1975; Welsh, Jr. and Ollivier, 1998; Jung et al., 2000, Rocco and Brooks, 2000). Therefore, the differences in relative abundance between treatments were not likely due to natural fluctuation. The pilot study that I conducted in 2001 provides further support for this statement because its results also suggested greater relative abundance in RS. Between-year statistical comparisons were not appropriate because the streams sampled in 2001 were not paired by order and mesohabitat and because I used different search techniques between years. While density is not always a reliable indicator of habitat quality for other taxa (e.g. birds; Van Horne, 1983), Krzysik (1979) defines an optimal locality for a streambank salamander to be one that supports the highest densities of a given species. Furthermore, Corn and Bury (1989) state that density of stream amphibians is likely to be a good indicator of habitat quality. Therefore, my results strongly suggest that RS provide more suitable habitats for stream salamanders than VFS. 
Table 1. Habitat characteristics at reference streams $(\mathrm{N}=3)$ and valley fill streams $(\mathrm{N}=4)$ by stream orderin a reclaimed mountaintop removal mine landscape in southern West Virginia, 2001. Habitat characteristics based on Amphibian Monitoring Program protocol (Jung et al. 1999): BA = bank (river edge, soil, lacks rocks); $\mathrm{RU}=$ run (smooth current); $\mathrm{BL}=$ boulder $(>1.5 \mathrm{~m}$ in diameter); $\mathrm{RA}=$ rapid (fast current broken by obstructions); $\mathrm{LR}=$ large rocks ( $0.5-1.5 \mathrm{~m}$ in diameter); $\mathrm{PO}=$ pool (standing water); $\mathrm{SR}=$ small rocks (0.1-0.5 $\mathrm{m}$ in diameter); $\mathrm{CA}=$ cascade (water flowing over slanting rocks); $\mathrm{RG}$ $=$ rubble $/$ gravel $(<0.1 \mathrm{~m}$ in diameter $) ; \mathrm{RI}=$ riffle (ripples and waves); $\mathrm{WD}=$ woody debris; $\mathrm{DR}=$ dry (no visible moisture or water).

\begin{tabular}{|c|c|c|c|c|c|}
\hline $\begin{array}{l}\text { Site } \\
\text { No. }\end{array}$ & Segment & Substrate Type & $\begin{array}{c}\text { Channel } \\
\text { Type }\end{array}$ & $\begin{array}{c}\text { No. of Coarse } \\
\text { Woody Debris } \\
\text { Sampled }\end{array}$ & $\begin{array}{c}\text { No. of Rocks } \\
\text { Sampled }\end{array}$ \\
\hline \multicolumn{6}{|c|}{ Valley Fill Streams - Second Order } \\
\hline \multirow[t]{5}{*}{5} & 1 & SR, RG & RI & 21 & 689 \\
\hline & 2 & $\mathrm{SR}, \mathrm{RG}$ & RI & 7 & 480 \\
\hline & 3 & $\mathrm{SR}, \mathrm{RG}$ & RI & 12 & 137 \\
\hline & 4 & SR, RG, BA & RI & 6 & 1554 \\
\hline & 5 & SR, RG, BA & RI & 19 & 821 \\
\hline \multirow[t]{5}{*}{44} & 1 & SR, RG, WD & $\mathrm{PO}, \mathrm{RU}$ & 24 & 67 \\
\hline & 2 & SR, RG, WD & RU & 74 & 71 \\
\hline & 3 & SR, RG, WD & RU & 39 & 98 \\
\hline & 4 & SR, RG, BA, WD & RI, PO, RU & 95 & 75 \\
\hline & 5 & SR, RG, BA, WD & RI, PO, RU & 104 & 127 \\
\hline \multirow[t]{2}{*}{173} & 1 & SR, RG, BA, WD & RI, PO & 19 & 3012 \\
\hline & 2 & SR, RG, BA & RI & 0 & 1495 \\
\hline \multicolumn{6}{|c|}{ Valley Fill Streams - Third Order } \\
\hline \multirow[t]{5}{*}{131} & 1 & SR, RG, LR & RA & 5 & 758 \\
\hline & 2 & SR, RG, LR & RA & 5 & 457 \\
\hline & 3 & $\mathrm{SR}, \mathrm{RG}, \mathrm{LR}, \mathrm{BL}$ & $\mathrm{RA}, \mathrm{PO}$ & 0 & 343 \\
\hline & 4 & SR, RG, BA, LR & RI & 6 & 1266 \\
\hline & 5 & SR, RG, BA & RI, PO & 25 & 1935 \\
\hline \multicolumn{6}{|c|}{ Reference Streams - Intermittent } \\
\hline \multirow[t]{3}{*}{112} & 1 & SR, LR & $\mathrm{RI}, \mathrm{PO}, \mathrm{CA}$ & 25 & 638 \\
\hline & 2 & SR, LR & DR & 37 & 527 \\
\hline & 5 & SR, LR, BA & DR & 28 & 1144 \\
\hline \multicolumn{6}{|c|}{ Reference Streams - First Order } \\
\hline \multirow[t]{5}{*}{21} & 1 & SR & RI & 67 & 392 \\
\hline & 2 & SR & RI & 38 & 579 \\
\hline & 3 & SR, RG, WD & RI & 18 & 345 \\
\hline & 4 & SR, WD & $\mathrm{RI}, \mathrm{PO}$ & 61 & 1473 \\
\hline & 5 & SR, WD & RI, PO & 3 & 1219 \\
\hline \multirow[t]{5}{*}{165} & 1 & SR, LR & RI, PO & 13 & 157 \\
\hline & 2 & SR, WD & $\mathrm{PO}$ & 46 & 140 \\
\hline & 3 & SR, WD & DR & 70 & 34 \\
\hline & 4 & SR, BA, WD & $\mathrm{DR}, \mathrm{PO}$ & 16 & 223 \\
\hline & 5 & SR, BA, WD, LR & DR, PO & 111 & 698 \\
\hline \multicolumn{6}{|c|}{ Reference Streams - Second Order } \\
\hline 112 & 3 & $\mathrm{SR}, \mathrm{R} / \mathrm{G}$ & RI, PO & 9 & 342 \\
\hline & 4 & $\mathrm{SR}, \mathrm{R} / \mathrm{G}, \mathrm{BA}$ & $\mathrm{RI}, \mathrm{PO}$ & 3 & 2928 \\
\hline
\end{tabular}


Table 2. Number of $10 \mathrm{~m} \times 2 \mathrm{~m}$ transects in each treatment surveyed for stream salamanders in a reclaimed mountaintop removal mine landscape in southern West Virginia, June-November, 2002.

\begin{tabular}{|c|c|c|c|c|}
\hline \multirow[b]{2}{*}{ Streams } & \multicolumn{2}{|c|}{$1^{\text {st }}$ Order } & \multicolumn{2}{|c|}{$2^{\text {nd }}$ Order } \\
\hline & Pool & Riffle & Pool & Riffle \\
\hline \multicolumn{5}{|l|}{ Reference Streams } \\
\hline Pigeonroost Branch & 1 & 2 & 1 & 2 \\
\hline Bend Branch & 2 & 1 & 1 & 2 \\
\hline Ash Fork & 1 & 2 & 1 & 2 \\
\hline Total & 4 & 5 & 3 & 6 \\
\hline \multicolumn{5}{|l|}{ Valley Fill Streams } \\
\hline Big Horse Creek & 1 & 2 & 1 & 2 \\
\hline Rockhouse Creek & 1 & 2 & 1 & 2 \\
\hline Hughe's Fork & 1 & 2 & 1 & 2 \\
\hline Total & 3 & 6 & 3 & 6 \\
\hline
\end{tabular}


Table 3. Description of habitat variables measured at each $10 \mathrm{~m}$ x $2 \mathrm{~m}$ stream transect, 2002. All definitions are verbatim from Jung (2002), with the exception of those marked with an asterisk. I created and defined habitat variables marked with an asterisk.

\begin{tabular}{|c|c|}
\hline Habitat Variables & Descriptions \\
\hline Wet Stream Width* & Width of stream between the water edges. \\
\hline Moist Stream Width* & Width of stream beyond the water edges, where the soil is moist. \\
\hline Bankfull Width* & Width of stream between bank edges. \\
\hline \multicolumn{2}{|l|}{ Sky Codes } \\
\hline 0 & Clear or few clouds (<20\% of sky covered with clouds) \\
\hline 1 & Partly cloudy or variable (20-50\% of sky covered with clouds) \\
\hline 2 & Cloudy or overcast (> 50\% of sky covered wtih clouds) \\
\hline 3 & Fog \\
\hline 4 & Mist or drizzle \\
\hline 5 & Showers or light rain \\
\hline 6 & Heavy rain \\
\hline 7 & Sleet or hail \\
\hline 8 & Snow \\
\hline \multicolumn{2}{|l|}{ Wind Codes } \\
\hline 0 & $<1 \mathrm{mph}$, calm, smoke rises vertically \\
\hline 1 & 2-3 mph, light air movement, smoke drifts \\
\hline 2 & 4-7 mph, light breeze, wind felt on face, leaves rustle \\
\hline 3 & $8-12 \mathrm{mph}$, gentle breeze, leaves in constant motion, raises dust \\
\hline 4 & 13-18 mph, moderate breeze, small branches move \\
\hline 5 & 19-24 mph, fresh breeze, small trees begin to sway \\
\hline 6 & 25-31 mph, strong breeze, large branches move \\
\hline 7 & $32-38$, near gale, large trees begin to sway, difficult to walk \\
\hline \multicolumn{2}{|l|}{ Mesohabitat Types } \\
\hline Dry & No visible moisture or water \\
\hline Moist & No flow, but moist soil \\
\hline Seep & Slow flow, trickle or drip \\
\hline Pool & Standing / stagnant water \\
\hline Riffle & Riffle / small waves, not caused by obstruction \\
\hline Run & Swiftly-moving, smooth surface current \\
\hline \multicolumn{2}{|l|}{ Cover Types } \\
\hline Sand & $<2 \mathrm{~mm}$, gritty texture \\
\hline Gravel & $2-32 \mathrm{~mm}$ \\
\hline Pebble & $33-64 \mathrm{~mm}$ \\
\hline Cobble & $65-256 \mathrm{~mm}$ \\
\hline Boulders & $>256 \mathrm{~mm}$ \\
\hline Silt & Particles $<2 \mathrm{~mm}$, greasy texture when rubbed with fingers; clay and fine organic \\
\hline Fine sediment & Sand and silt \\
\hline Detritus & Partially or undecayed stickes, wood, leaves, or other plant material \\
\hline Clay / Hardpan & Hard and gummy, hard to penetrate \\
\hline Muck & Decayed organic matter with little or no clay \\
\hline After-cobble* & Total percent cover of cobble when detritus was not taken into consideration \\
\hline After-boulder* & Total percent cover of boulders when detritus was not taken into consideration \\
\hline
\end{tabular}


Table 4. Number of individuals and species of herpetofaunal groups captured in stream surveys in 1 intermittent reference stream (3 35-m stream segments sampled), 2 first-order reference streams (7 35-m stream segments sampled), 1 second-order reference stream (5 35-m stream segments sampled), and 4 second-order valley fill streams (17 35-m stream segments sampled), on reclaimed mountaintop removal mine areas in southern West Virginia, May-October, 2001.

\begin{tabular}{|c|c|c|c|c|c|}
\hline \multirow[b]{2}{*}{ Species } & \multicolumn{2}{|c|}{ Valley Fill Streams } & \multicolumn{3}{|c|}{ Reference Streams } \\
\hline & $\begin{array}{c}\text { Second } \\
\text { Order }\end{array}$ & $\begin{array}{l}\text { Third } \\
\text { Order }\end{array}$ & Intermittent & $\begin{array}{l}\text { First } \\
\text { Order }\end{array}$ & $\begin{array}{l}\text { Second } \\
\text { Order }\end{array}$ \\
\hline \multicolumn{6}{|l|}{ Salamanders } \\
\hline Cumberland Plateau Salamander & & & 1 & & \\
\hline Eastern Red-backed Salamander & & & 8 & & \\
\hline Seal Salamander & 7 & 8 & 34 & 57 & 17 \\
\hline Northern Dusky Salamander & 76 & 42 & & 102 & 47 \\
\hline $\begin{array}{l}\text { Desmognathus spp. (Seal or N. } \\
\text { Dusky) }\end{array}$ & 7 & 8 & 8 & 22 & 8 \\
\hline Southern Two-lined Salamander & 57 & 15 & 8 & 21 & 7 \\
\hline Long-tailed Salamander & 1 & 1 & & & \\
\hline Northern Spring Salamander & 2 & & 1 & 2 & 1 \\
\hline Red-Spotted Newt & 6 & 2 & & 1 & 4 \\
\hline Northern Red Salamander & & 1 & 1 & & \\
\hline Unidentified Salamander & 20 & 20 & 2 & 28 & 6 \\
\hline Total & 176 & 97 & 63 & 233 & 90 \\
\hline \multicolumn{6}{|l|}{ Toads and Frogs } \\
\hline Fowler's Toad & 1 & & & & \\
\hline American Bullfrog & 1 & & & 1 & \\
\hline Northern Green Frog & 5 & & & & \\
\hline Pickerel Frog & 3 & & & 1 & \\
\hline Rana spp. & 3 & & & & \\
\hline Unidentified Frog & & & & 1 & \\
\hline Total & 13 & 0 & 0 & 3 & 0 \\
\hline \multicolumn{6}{|l|}{ Snakes } \\
\hline Northern Ring-necked Snake & 1 & & & & \\
\hline Common Watersnake & 1 & 1 & & & \\
\hline \multirow{2}{*}{ Total } & 2 & 1 & 0 & 0 & 0 \\
\hline & 191 & 98 & 63 & 236 & 90 \\
\hline Grand Total & & & & & \\
\hline
\end{tabular}


Table 5. Number of individuals and species captured $(\mathrm{N})$ and percent of total captures and of total species captured in stream surveys in valley fill streams and reference streams on and near reclaimed mountaintop removal mines in southern West Virginia, May-October, 2001.

\begin{tabular}{|c|c|c|c|c|c|c|c|c|}
\hline \multirow[b]{3}{*}{ Taxonomic Group } & \multicolumn{4}{|c|}{ Valley Fill Streams } & \multicolumn{4}{|c|}{ Reference Streams } \\
\hline & \multicolumn{2}{|c|}{ Individuals } & \multicolumn{2}{|c|}{ Species } & \multicolumn{2}{|c|}{ Individuals } & \multicolumn{2}{|c|}{ Species } \\
\hline & $\mathrm{N}$ & $\%$ & $\mathrm{~N}$ & $\%$ & $\mathrm{~N}$ & $\%$ & $\mathrm{~N}$ & $\%$ \\
\hline Salamanders & 270 & 93.4 & 7 & 53.8 & 385 & 99.2 & 8 & 80.0 \\
\hline Toads and frogs & 16 & 5.5 & 4 & 30.8 & 3 & 0.8 & 2 & 20.0 \\
\hline Lizards & 0 & 0.0 & 0 & 0.0 & 0 & 0.0 & 0 & 0.0 \\
\hline Snakes & 3 & 1.1 & 2 & 15.4 & 0 & 0.0 & 0 & 0.0 \\
\hline Turtles & 0 & 0.0 & 0 & 0.0 & 0 & 0.0 & 0 & 0.0 \\
\hline
\end{tabular}

Table 6. Mean and standard error (SE) of stream salamanders per 35-m segment of valley fill and reference streams on and near reclaimed mountaintop removal mines in southwestern West Virginia, May-October 2001.

\begin{tabular}{|c|c|c|c|c|c|}
\hline Treatment & Stream & $\begin{array}{c}\text { No. } \\
\text { Segments } \\
\text { Sampled }\end{array}$ & $\begin{array}{l}\text { Stream } \\
\text { Classification }\end{array}$ & Mean & SE \\
\hline \multirow[t]{4}{*}{ Reference Stream } & Pigeonroost Branch & 3 & Intermittent & 21.00 & 6.11 \\
\hline & Spring Branch & 5 & First Order & 16.00 & 2.74 \\
\hline & Ash Fork & 5 & First Order & 30.60 & 9.08 \\
\hline & Pigeonroost Branch & 2 & Second Order & 45.00 & 25.00 \\
\hline \multirow[t]{4}{*}{ Valley Fill Stream } & Big Horse Creek & 5 & Second Order & 5.40 & 0.93 \\
\hline & Lavender Fork & 5 & Second Order & 1.80 & 0.97 \\
\hline & Rockhouse Creek & 2 & Second Order & 68.50 & 7.50 \\
\hline & Hughe's Fork & 5 & Third Order & 19.40 & 7.53 \\
\hline
\end{tabular}


Table 7. Number of captures per stream salamander species and age class $(\mathrm{A}=$ adult, $\mathrm{L}=$ larvae $)$ in each treatment surveyed for stream salamanders in a reclaimed mountaintop removal mine landscape in southern West Virginia, June-November, 2002. DEFU = Northern Dusky Salamander (Desmognathus fuscus); DEMO = Seal Salamander (D. monticola); DESP = Desmognathus spp.; EUCI - Southern Two-lined Salamander (Eurycea cirrigera); GYPO = Spring Salamander (Gyrinophilus porphyriticus); PSRU = Northern Red Salamander (Pseudotriton ruber); UNK = Unknown spp.

\begin{tabular}{|c|c|c|c|c|c|c|c|c|c|c|c|c|c|c|}
\hline \multirow[b]{3}{*}{ Stream } & \multicolumn{14}{|c|}{ Species } \\
\hline & \multicolumn{2}{|c|}{ DEFU } & \multicolumn{2}{|c|}{ DEMO } & \multicolumn{2}{|c|}{ DESP } & \multicolumn{2}{|c|}{ EUCI } & \multicolumn{2}{|c|}{ GYPO } & \multicolumn{2}{|c|}{ PSRU } & \multicolumn{2}{|c|}{ UNK } \\
\hline & A & $\mathrm{L}$ & A & $\mathrm{L}$ & A & $\mathrm{L}$ & A & $\mathrm{L}$ & A & $\mathrm{L}$ & A & $\mathrm{L}$ & A & $\mathrm{L}$ \\
\hline \multicolumn{15}{|l|}{ Reference Streams } \\
\hline Pigeonroost Branch & 54 & 16 & 47 & 0 & 27 & 24 & 6 & 0 & 0 & 4 & 0 & 0 & 0 & 437 \\
\hline Bend Branch & 22 & 0 & 77 & 0 & 42 & 46 & 12 & 0 & 0 & 26 & 0 & 0 & 2 & 91 \\
\hline Ash Fork & 88 & 1 & 109 & 3 & 75 & 118 & 11 & 15 & 1 & 43 & 0 & 0 & 2 & 164 \\
\hline Total & 164 & 17 & 233 & 3 & 144 & 188 & 29 & 15 & 1 & 73 & 0 & 0 & 4 & 692 \\
\hline \multicolumn{15}{|l|}{ Valley Fill Streams } \\
\hline Big Horse Creek & 13 & 0 & 19 & 0 & 3 & 16 & 0 & 0 & 0 & 3 & 1 & 0 & 1 & 166 \\
\hline Rockhouse Creek & 92 & 7 & 22 & 0 & 8 & 53 & 15 & 70 & 0 & 2 & 0 & 0 & 0 & 30 \\
\hline Hughe's Fork & 66 & 0 & 8 & 0 & 6 & 53 & 1 & 6 & 0 & 1 & 0 & 0 & 0 & 118 \\
\hline Total & 171 & 7 & 49 & 0 & 17 & 122 & 16 & 76 & 0 & 6 & 1 & 0 & 1 & 314 \\
\hline
\end{tabular}


Table 8. Mean, standard error (SE), and range of relative abundance of stream salamanders (individuals $/ \mathrm{m}^{2}$ ) captured in reference streams and valley fill streams in a reclaimed mountaintop removal mine landscape in southern West Virginia, July to November, 2002. There was a significant interaction between treatment and season in 2 nd order reaches for adult salamanders and adult Desmognathus spp., so I analyzed seasons separately.

\begin{tabular}{|c|c|c|c|c|c|c|c|c|}
\hline \multirow[b]{2}{*}{ Group } & \multicolumn{3}{|c|}{ Reference Streams } & \multicolumn{3}{|c|}{ Valley Fill Streams } & \multirow[b]{2}{*}{$\mathrm{F}$} & \multirow[b]{2}{*}{$P$} \\
\hline & Mean & $\mathrm{SE}$ & Range & Mean & $\mathrm{SE}$ & Range & & \\
\hline Total Salamanders & 6.52 & 0.95 & $2.40-14.70$ & 3.25 & 0.32 & $1.60-4.85$ & 7.99 & 0.05 \\
\hline Summer & 6.72 & 1.75 & $2.40-14.70$ & 2.65 & 0.39 & $1.60-4.30$ & & \\
\hline Fall & 6.32 & 0.94 & $3.95-9.65$ & 3.85 & 0.38 & $2.25-4.85$ & & \\
\hline 1 st order & 5.99 & 0.92 & $3.95-9.65$ & 3.63 & 0.29 & $2.65-4.50$ & 3.54 & 0.13 \\
\hline Summer & 5.93 & 0.96 & $4.05-7.20$ & 3.33 & 0.50 & $2.65-4.30$ & & \\
\hline Fall & 6.05 & 1.81 & $3.95-9.65$ & 3.93 & 0.31 & $3.45-4.50$ & & \\
\hline 2nd order & 7.04 & 1.73 & $2.40-14.70$ & 2.87 & 0.54 & $1.60-4.85$ & 8.00 & 0.05 \\
\hline Summer & 7.5 & 3.7 & $2.40-14.70$ & 1.97 & 0.22 & $1.60-2.35$ & & \\
\hline Fall & 6.58 & 1.03 & $4.95-8.50$ & 3.77 & 0.78 & $2.25-4.85$ & & \\
\hline Adult Salamanders & 2.40 & 0.42 & $0.50-5.60$ & 1.06 & 0.20 & $0.20-2.75$ & 1.74 & 0.26 \\
\hline Summer & 3.00 & 0.72 & $1.35-5.60$ & 1.14 & 0.38 & $0.20-2.75$ & & \\
\hline Fall & 1.80 & 0.36 & $0.50-3.10$ & 0.98 & 0.16 & $0.35-1.35$ & & \\
\hline 1 st order & 2.92 & 0.61 & $1.60-5.60$ & 1.18 & 0.33 & $0.60-2.75$ & 9.35 & 0.04 \\
\hline Summer & 3.58 & 1.12 & $1.75-5.60$ & 1.33 & 0.71 & $0.60-2.75$ & & \\
\hline Fall & 2.25 & 0.44 & $1.60-3.10$ & 1.02 & 0.16 & $0.70-1.25$ & & \\
\hline 2 nd order & 1.88 & 0.55 & $0.50-4.40$ & 0.95 & 0.23 & $0.20-1.65$ & -- & -- \\
\hline Summer & 2.42 & 0.99 & $1.35-4.40$ & 0.95 & 0.42 & $0.20-1.65$ & & \\
\hline Fall & 1.35 & 0.51 & $0.50-2.20$ & 0.95 & 0.31 & $0.35-1.35$ & & \\
\hline Adult Desmognathus & 2.26 & 0.44 & $0.50-5.55$ & 0.99 & 0.17 & $0.15-2.40$ & 3.58 & 0.13 \\
\hline Summer & 2.92 & 0.72 & $1.20-5.55$ & 1.06 & 0.33 & $0.15-2.40$ & & \\
\hline Fall & 1.6 & 0.38 & $0.50-3.10$ & 0.92 & 0.14 & $0.35-1.25$ & & \\
\hline 1 st order & 2.84 & 0.63 & $1.45-5.55$ & 1.08 & 0.28 & $0.55-2.40$ & 11.64 & 0.03 \\
\hline Summer & 3.52 & 1.14 & $1.60-5.55$ & 1.20 & 0.6 & $0.55-2.40$ & & \\
\hline Fall & 2.17 & 0.49 & $1.45-3.10$ & 0.97 & 0.16 & $0.70-1.25$ & & \\
\hline 2 nd order & 1.68 & 0.55 & $0.50-4.25$ & 0.89 & 0.22 & $0.15-1.60$ & -- & -- \\
\hline Summer & 2.32 & 0.97 & $1.20-4.25$ & 0.92 & 0.42 & $0.15-1.60$ & 2.09 & 0.22 \\
\hline Fall & 1.03 & 0.41 & $0.50-1.85$ & 0.87 & 0.26 & $0.35-1.15$ & 0.09 & 0.78 \\
\hline Larval Salamanders & 4.91 & 0.88 & $1.50-11.90$ & 2.29 & 0.29 & $0.60-3.55$ & 5.54 & 0.08 \\
\hline Summer & 4.86 & 1.55 & $1.50-11.95$ & 1.56 & 0.29 & $0.60-2.45$ & & \\
\hline Fall & 4.97 & 0.99 & $2.25-8.10$ & 3.03 & 0.26 & $2.05-3.55$ & & \\
\hline 1 st order & 4.10 & 0.90 & $1.90-7.80$ & 2.58 & 0.29 & $1.75-3.50$ & 0.92 & 0.39 \\
\hline Summer & 3.73 & 1.02 & $1.90-5.45$ & 2.07 & 0.20 & $1.75-2.45$ & & \\
\hline Fall & 4.47 & 1.70 & $2.25-7.80$ & 3.10 & 0.35 & $2.40-3.50$ & & \\
\hline 2nd order & 5.73 & 1.52 & $1.50-11.95$ & 2.00 & 0.50 & $0.60-3.55$ & 8.88 & 0.04 \\
\hline Summer & 5.98 & 3.10 & $1.50-11.95$ & 1.05 & 0.35 & $0.60-1.75$ & & \\
\hline Fall & 5.47 & 1.33 & $3.85-8.10$ & 2.95 & 0.46 & $2.05-3.55$ & & \\
\hline
\end{tabular}


Table 9. Mean, standard error (SE), and range of habitat variables measured in reference and valley fill streams in a reclaimed mountaintop removal mine landscape in southern West Virginia, June to November, 2002. $\mathrm{O}=$ overall ( 1 st order and 2 nd order reaches combined), $1=1$ st order stream reaches, $2=2$ nd order stream reaches. I did not compute statistics for variables with $0 \%$ cover in both treatments or for variables with sample sizes too small for statistical analyses.

\begin{tabular}{|c|c|c|c|c|c|c|c|c|c|}
\hline \multirow[b]{2}{*}{ Variable } & \multirow[b]{2}{*}{ Order } & \multicolumn{3}{|c|}{ Reference Streams } & \multicolumn{3}{|c|}{ Valley Fill Streams } & \multirow[b]{2}{*}{$\mathrm{F}$} & \multirow[b]{2}{*}{$P$} \\
\hline & & Mean & $\mathrm{SE}$ & Range & Mean & $\mathrm{SE}$ & Range & & \\
\hline \multirow[t]{3}{*}{ Gradient (\%) } & $\mathrm{O}$ & 2.23 & 0.42 & $0-6$ & 1.56 & 0.20 & $0.5-4$ & 0.40 & 0.56 \\
\hline & 1 & 3.00 & 0.63 & $1.0-6$ & 1.56 & 0.39 & $0.5-4$ & 1.32 & 0.32 \\
\hline & 2 & 1.36 & 0.36 & $0-3$ & 1.56 & 0.18 & $1-2$ & 0.43 & 0.55 \\
\hline \multicolumn{10}{|c|}{ Stream Width (cm) } \\
\hline \multirow[t]{3}{*}{ Wet } & $\mathrm{O}$ & 184.92 & 8.51 & $35-430$ & 227.43 & 10.20 & $47-542$ & 1.44 & 0.30 \\
\hline & 1 & 151.41 & 7.66 & $50-260$ & 186.83 & 11.32 & $47-362$ & 1.20 & 0.33 \\
\hline & 2 & 213.46 & 13.22 & $35-430$ & 270.41 & 15.16 & $95-542$ & 1.24 & 0.33 \\
\hline \multirow[t]{3}{*}{ Moist } & $\mathrm{O}$ & 246.80 & 11.24 & $120-468$ & 294.69 & 17.72 & $105-555$ & 0.50 & 0.52 \\
\hline & 1 & 201.00 & 11.44 & $120-302$ & 265.74 & 24.19 & $105-530$ & 1.02 & 0.37 \\
\hline & 2 & 292.59 & 14.94 & $165-468$ & 323.63 & 25.12 & $120-555$ & 0.17 & 0.70 \\
\hline \multirow[t]{3}{*}{ Bankfull } & $\mathrm{O}$ & 463.57 & 16.28 & $200-750$ & 501.20 & 33.07 & 160-1099 & 0.08 & 0.79 \\
\hline & 1 & 439.19 & 27.17 & $200-750$ & 524.59 & 47.18 & 230-1099 & 0.36 & 0.58 \\
\hline & 2 & 487.96 & 17.21 & $260-700$ & 477.82 & 46.81 & $160-1050$ & 0.01 & 0.94 \\
\hline \multicolumn{10}{|c|}{ Mesohabitat (\%) } \\
\hline \multirow[t]{3}{*}{ Dry } & $\mathrm{O}$ & 0.00 & 0.00 & $0-0$ & 0.00 & 0.00 & $0-0$ & ---- & ---- \\
\hline & 1 & 0.00 & 0.00 & $0-0$ & 0.00 & 0.00 & $0-0$ & ---- & ---- \\
\hline & 2 & 0.00 & 0.00 & $0-0$ & 0.00 & 0.00 & $0-0$ & ----- & ---- \\
\hline \multirow[t]{3}{*}{ Moist } & $\mathrm{O}$ & 46.47 & 2.56 & $10-51.5$ & 46.16 & 3.08 & $2-55$ & 0.00 & 0.98 \\
\hline & 1 & 47.22 & 2.78 & $25-50$ & 42.75 & 5.71 & $2-55$ & 0.33 & 0.60 \\
\hline & 2 & 45.72 & 4.47 & $10-51.5$ & 50.00 & 0.00 & $50-50$ & 0.89 & 0.40 \\
\hline \multirow[t]{3}{*}{ Seep } & $\mathrm{O}$ & 0.00 & 0.00 & $0-0$ & 0.00 & 0.00 & $0-0$ & ----- & ----- \\
\hline & 1 & 0.00 & 0.00 & $0-0$ & 0.00 & 0.00 & $0-0$ & ----- & ---- \\
\hline & 2 & 0.00 & 0.00 & $0-0$ & 0.00 & 0.00 & $0-0$ & ---- & ---- \\
\hline \multirow[t]{3}{*}{ Pool } & $\mathrm{O}$ & 11.75 & 2.33 & $0-30$ & 9.38 & 2.87 & $0-40$ & 0.38 & 0.57 \\
\hline & 1 & 14.06 & 2.67 & $4-25$ & 7.17 & 2.52 & $0-25$ & 1.83 & 0.25 \\
\hline & 2 & 9.44 & 3.83 & $0-30$ & 11.88 & 5.48 & $0-40$ & 0.42 & 0.55 \\
\hline \multirow[t]{3}{*}{ Riffle } & $\mathrm{O}$ & 39.36 & 3.29 & $20-80$ & 40.60 & 4.13 & $10-85$ & 0.02 & 0.90 \\
\hline & 1 & 35.94 & 2.67 & $25-46$ & 42.81 & 6.31 & $23.25-85$ & 1.15 & 0.34 \\
\hline & 2 & 42.78 & 5.99 & $20-80$ & 38.13 & 5.48 & $10-50$ & 0.68 & 0.45 \\
\hline \multirow[t]{3}{*}{ Run } & $\mathrm{O}$ & 2.50 & 1.73 & $0-25$ & 2.09 & 1.51 & $0-25$ & 0.09 & 0.78 \\
\hline & 1 & 2.78 & 2.78 & $0-25$ & 3.94 & 2.78 & $0-25$ & 0.10 & 0.77 \\
\hline & 2 & 2.22 & 2.22 & $0-20$ & 0.00 & 0.00 & $0-0$ & 1.00 & 0.37 \\
\hline \multirow[t]{3}{*}{ Sand } & $\mathrm{O}$ & 2.86 & 0.56 & $0-6$ & 2.28 & 0.67 & $0-8.5$ & 0.08 & 0.79 \\
\hline & 1 & 2.94 & 0.83 & $0-6$ & 2.56 & 0.97 & $0-7$ & 0.04 & 0.86 \\
\hline & 2 & 2.78 & 0.81 & $0-5$ & 2.00 & 0.98 & $0-8.5$ & 0.13 & 0.74 \\
\hline
\end{tabular}


Table 9. Cont'd.

\begin{tabular}{|c|c|c|c|c|c|c|c|c|c|}
\hline \multirow[b]{2}{*}{ Variable } & \multirow[b]{2}{*}{ Order } & \multicolumn{3}{|c|}{ Reference Streams } & \multicolumn{3}{|c|}{ Valley Fill Streams } & \multirow[b]{2}{*}{$\mathrm{F}$} & \multirow[b]{2}{*}{$P$} \\
\hline & & Mean & SE & Range & Mean & SE & Range & & \\
\hline \multirow[t]{3}{*}{ Gravel } & $\mathrm{O}$ & 8.11 & 1.46 & $0-20$ & 4.64 & 1.30 & $0-20$ & 0.76 & 0.43 \\
\hline & 1 & 9.17 & 2.50 & $0-20$ & 3.61 & 1.29 & $0-10$ & 1.25 & 0.33 \\
\hline & 2 & 7.06 & 1.59 & $1-15$ & 5.67 & 2.29 & $0-20$ & 0.13 & 0.73 \\
\hline \multirow[t]{3}{*}{ Pebble } & $\mathrm{O}$ & 6.89 & 1.63 & $0-30$ & 5.92 & 1.75 & $0-23$ & 0.10 & 0.77 \\
\hline & 1 & 7.17 & 3.21 & $0-30$ & 4.00 & 1.96 & $0-18.5$ & 0.37 & 0.58 \\
\hline & 2 & 6.61 & 0.96 & $2-10$ & 7.83 & 2.88 & $0-23$ & 0.10 & 0.76 \\
\hline \multirow[t]{3}{*}{ Cobble } & $\mathrm{O}$ & 24.67 & 3.44 & $2-50$ & 14.89 & 2.11 & $3-30$ & 2.10 & 0.22 \\
\hline & 1 & 25.83 & 4.64 & $15-50$ & 16.67 & 2.64 & $5-30$ & 1.05 & 0.36 \\
\hline & 2 & 23.50 & 5.34 & $2-42$ & 13.11 & 3.34 & $3-30$ & 1.40 & 0.30 \\
\hline \multirow[t]{3}{*}{ After Cobble } & $\mathrm{O}$ & 54.41 & 5.35 & $20-85$ & 47.86 & 5.16 & $30-90$ & 0.11 & 0.76 \\
\hline & 1 & 55.56 & 7.69 & $27.5-85$ & 49.58 & 8.67 & $30-90$ & 0.09 & 0.78 \\
\hline & 2 & 53.13 & 7.92 & $20-80$ & 46.56 & 6.76 & $30-80$ & 0.04 & 0.84 \\
\hline \multirow[t]{3}{*}{ Boulder } & $\mathrm{O}$ & 7.78 & 0.79 & $2-15$ & 5.03 & 0.95 & $0-15$ & 4.24 & 0.11 \\
\hline & 1 & 7.78 & 1.24 & $3.5-15$ & 6.11 & 1.02 & $1.5-12.5$ & 1.11 & 0.35 \\
\hline & 2 & 7.78 & 1.06 & $2-10$ & 3.94 & 1.59 & $0-15$ & 4.49 & 0.10 \\
\hline \multirow[t]{3}{*}{ After Boulder } & $\mathrm{O}$ & 9.12 & 1.34 & $2-20$ & 5.82 & 1.21 & $0-15$ & 1.75 & 0.26 \\
\hline & 1 & 10.00 & 2.22 & $3.5-20$ & 6.83 & 1.69 & $0-12.5$ & 0.72 & 0.46 \\
\hline & 2 & 8.13 & 1.48 & $2-15$ & 5.06 & 1.75 & $0-15$ & 3.48 & 0.14 \\
\hline \multirow[t]{3}{*}{ Bedrock } & $\mathrm{O}$ & 0.56 & 0.38 & $0-5$ & 0.00 & 0.00 & $0-0$ & ----- & ----- \\
\hline & 1 & 0.56 & 0.56 & $0-5$ & 0.00 & 0.00 & $0-0$ & ----- & ---- \\
\hline & 2 & 0.56 & 0.56 & $0-5$ & 0.00 & 0.00 & $0-0$ & ----- & ----- \\
\hline \multirow[t]{3}{*}{ Silt } & $\mathrm{O}$ & 13.53 & 3.16 & $0-35$ & 28.33 & 3.65 & $0-50$ & 7.05 & 0.06 \\
\hline & 1 & 7.00 & 2.98 & $0-23$ & 28.89 & 4.13 & $10-45$ & 9.57 & 0.04 \\
\hline & 2 & 20.06 & 4.79 & $0-35$ & 27.78 & 6.30 & $0-50$ & 0.78 & 0.43 \\
\hline \multirow[t]{3}{*}{ Fine sediment } & $\mathrm{O}$ & 16.39 & 3.36 & $0-40$ & 30.61 & 3.77 & $0-50$ & 4.30 & 0.11 \\
\hline & 1 & 9.94 & 3.49 & $0-28$ & 31.44 & 4.05 & $10-45$ & 7.87 & 0.05 \\
\hline & 2 & 22.83 & 5.04 & $0-40$ & 29.78 & 6.62 & $0-50$ & 0.49 & 0.52 \\
\hline \multirow[t]{3}{*}{ Detritus } & $\mathrm{O}$ & 35.89 & 5.70 & $5-80$ & 38.00 & 4.13 & $10-75$ & 0.02 & 0.89 \\
\hline & 1 & 40.11 & 10.65 & $5-80$ & 36.89 & 6.05 & $10-72$ & 0.02 & 0.88 \\
\hline & 2 & 31.67 & 4.47 & $7.5-50$ & 39.11 & 5.97 & $10-75$ & 0.46 & 0.53 \\
\hline \multirow[t]{3}{*}{ Muck } & $\mathrm{O}$ & 0.00 & 0.00 & $0-0$ & 0.86 & 0.39 & $0-5$ & 1.00 & 0.37 \\
\hline & 1 & 0.00 & 0.00 & $0-0$ & 1.28 & 0.72 & $0-5$ & 1.00 & 0.37 \\
\hline & 2 & 0.00 & 0.00 & $0-0$ & 0.44 & 0.31 & $0-2.5$ & 1.00 & 0.37 \\
\hline
\end{tabular}


Table 10. Correlations between salamander groupings and habitat variables in valley fill and reference streams in a reclaimed mountaintop mine landscape in southern West Virginia, 2002. Significant at $P=0.0053$ (Bonferroni adjustment).

\begin{tabular}{|c|c|c|c|c|c|c|c|c|c|c|c|c|}
\hline \multirow[b]{2}{*}{ Habitat Variables } & \multicolumn{3}{|c|}{ Total Salamanders } & \multicolumn{3}{|c|}{ Adult Salamanders } & \multicolumn{3}{|c|}{ Adult Desmognathus spp. } & \multicolumn{3}{|c|}{ Larval Salamanders } \\
\hline & $\mathrm{R}^{2}$ & $\mathrm{~F}$ & $P$ & $\mathrm{R}^{2}$ & $\mathrm{~F}$ & $P$ & $\mathrm{R}^{2}$ & $\mathrm{~F}$ & $P$ & $\mathrm{R}^{2}$ & $\mathrm{~F}$ & $P$ \\
\hline Gradient (\%) & 0.61 & 2.72 & 0.12 & 0.64 & 3.15 & 0.09 & 0.66 & 3.40 & 0.08 & 0.71 & 4.36 & 0.04 \\
\hline Wet & 0.57 & 2.30 & 0.16 & 0.64 & 3.05 & 0.09 & 0.65 & 3.32 & 0.08 & 0.51 & 1.81 & 0.23 \\
\hline Moist & 0.51 & 1.79 & 0.24 & 0.66 & 3.40 & 0.08 & 0.67 & 3.54 & 0.07 & 0.52 & 1.90 & 0.22 \\
\hline Bankfull & 0.51 & 1.79 & 0.24 & 0.67 & 3.48 & 0.07 & 0.67 & 3.54 & 0.07 & 0.53 & 1.97 & 0.20 \\
\hline Moist & 0.53 & 1.97 & 0.20 & 0.61 & 2.70 & 0.12 & 0.64 & 3.08 & 0.09 & 0.50 & 1.73 & 0.25 \\
\hline Pool & 0.51 & 1.80 & 0.23 & 0.57 & 2.34 & 0.15 & 0.61 & 2.75 & 0.11 & 0.49 & 1.70 & 0.25 \\
\hline Riffle & 0.54 & 2.03 & 0.19 & 0.64 & 3.06 & 0.09 & 0.67 & 3.55 & 0.07 & 0.50 & 1.76 & 0.24 \\
\hline Run & 0.51 & 1.79 & 0.24 & 0.54 & 2.06 & 0.19 & 0.58 & 2.40 & 0.15 & 0.49 & 1.70 & 0.25 \\
\hline \multicolumn{13}{|l|}{ Cover $(\%)$} \\
\hline Cobble & 0.80 & 6.82 & 0.01 & 0.54 & 2.04 & 0.19 & 0.57 & 2.28 & 0.16 & 0.87 & 11.93 & 0.003 \\
\hline After Cobble & 0.86 & 9.56 & 0.01 & 0.63 & 2.55 & 0.15 & 0.66 & 2.88 & 0.12 & 0.78 & 5.42 & 0.03 \\
\hline Boulder & 0.77 & 5.97 & 0.02 & 0.54 & 2.07 & 0.19 & 0.58 & 2.37 & 0.15 & 0.82 & 8.09 & 0.009 \\
\hline After Boulder & 0.68 & 3.15 & 0.10 & 0.52 & 1.60 & 0.29 & 0.55 & 1.82 & 0.24 & 0.73 & 4.14 & 0.06 \\
\hline Bedrock & 0.79 & 6.41 & 0.02 & 0.58 & 2.42 & 0.14 & 0.62 & 2.87 & 0.11 & 0.79 & 6.72 & 0.02 \\
\hline Silt & 0.53 & 1.93 & 0.21 & 0.63 & 3.03 & 0.10 & 0.66 & 3.46 & 0.07 & 0.50 & 1.73 & 0.25 \\
\hline Fine sediment & 0.86 & 6.39 & 0.03 & 0.72 & 4.53 & 0.04 & 0.75 & 5.18 & 0.03 & 1.73 & 0.50 & 0.25 \\
\hline Detritus & 0.51 & 1.83 & 0.23 & 0.80 & 6.97 & 0.01 & 0.82 & 7.85 & 0.01 & 0.55 & 2.14 & 0.18 \\
\hline Muck & 0.51 & 1.81 & 0.23 & 0.59 & 2.55 & 0.13 & 0.61 & 2.79 & 0.11 & 0.50 & 1.72 & 0.25 \\
\hline
\end{tabular}




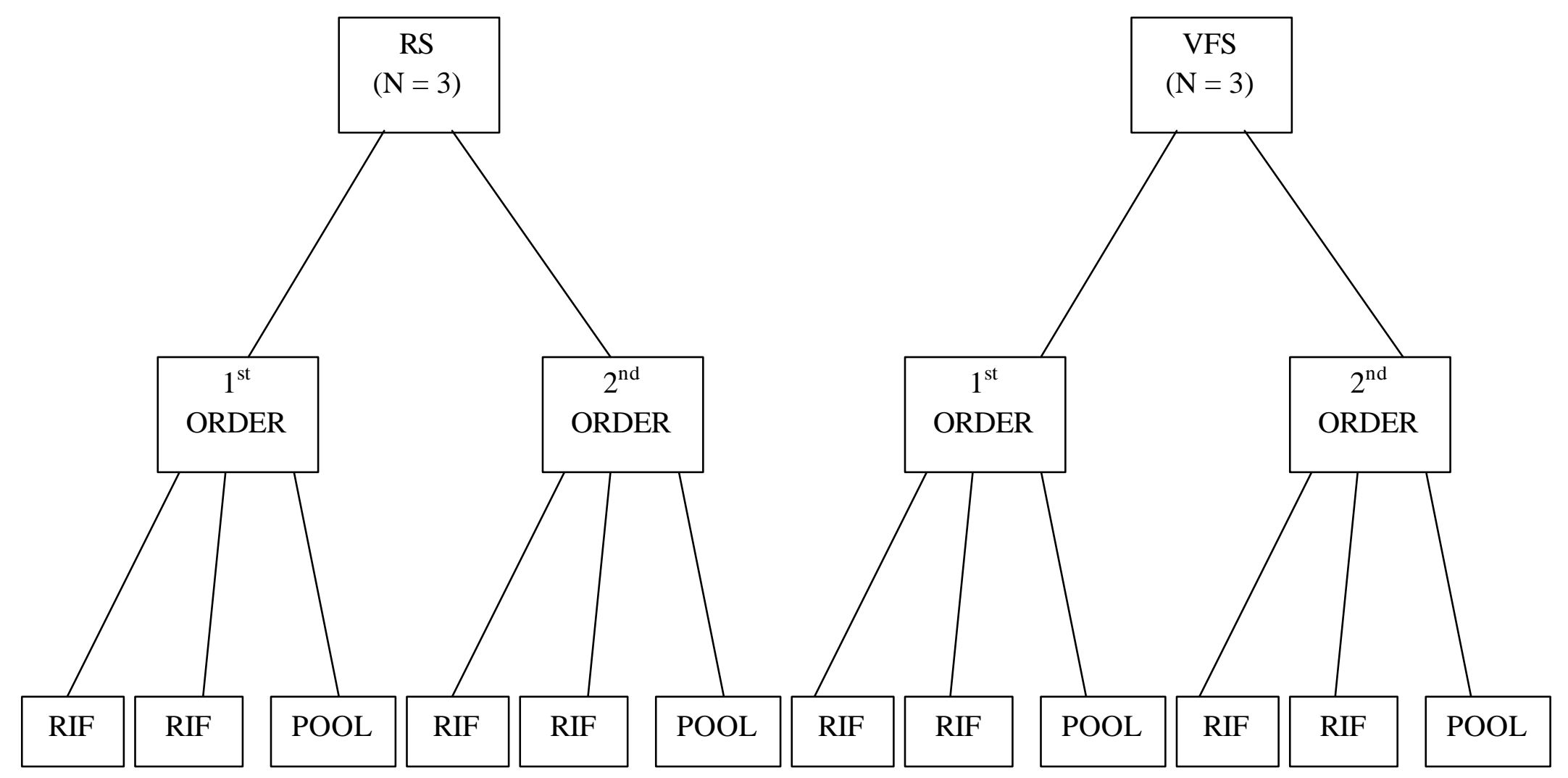

Figure 1. Stream sampling design for reference streams (RS) and valley fill streams (VFS) in a reclaimed mountaintop removal mine landscape in southern West Virginia. Transect dimensions were $10 \mathrm{~m} \mathrm{x} 2 \mathrm{~m}$ and were centered on riffles (RIF) and pools, 2002. 


\section{CHAPTER 4}

[This chapter is formatted in the style of Wildlife Society Bulletin.]

RH: Reclaimed mine edge effect on salamanders•Williams and Wood

\section{Edge effect of reclaimed mountaintop removal mine habitat on salamanders}

Abstract: Mountaintop removal mining converts landscapes from mature forests to extensive grasslands and shrub-pole habitats. This study is the first to document impacts of reclaimed mine edge on salamanders and to investigate use of reclaimed mine edge habitats by salamanders. Salamanders were sampled using 200-m coverboard transects that extended $100 \mathrm{~m}$ into forests and $100 \mathrm{~m}$ into reclaimed habitats. Relative abundance was compared among 5 treatments: forests, reclaimed grasslands, reclaimed shrub-pole habitats, edges between reclaimed grasslands and forests, and edges between reclaimed shrub-pole habitats and forests. Salamanders increased in relative abundance within forests with increasing distance from edge. Reclaimed grassland and shrub-pole habitats appeared to be less suitable for occupancy by salamanders than forests. Characteristics of reclaimed habitats included inadequate soil development, reduced vertical structure, lower percent canopy cover from overstory trees, and reduced percent cover by woody debris, all of which likely influenced habitat suitability for salamanders. Past research has shown that salamander populations reduced by clearcutting may rebound in 15 years. Time since disturbance varied from 7-19 years in reclaimed habitats and salamander populations have not yet recovered.

Key words: edge, forests, reclaimed habitats, salamanders, soil, terrestrial, vegetation

\section{Introduction}

Mountaintop removal mining, a large-scale surface mining method practiced in West Virginia, Virginia, Pennsylvania, Kentucky, and Tennessee (Barnhisel et al. 2000), results in conversion of large tracts of eastern deciduous forest to early successional habitats. During mining, geological strata become unconsolidated and intermixed with soil; topsoil is not separated before removal of other overburden (defined as geological strata above coal seams; Riley 1960).

Therefore, reclaimed mine surfaces frequently contain parent materials or other materials that have been subjected to little or no weathering (Sencindiver and Ammons 2000). Erosion, high surface and soil temperatures, limited moisture, extreme soil pH (Slick and Curtis 1985), lack of nutrients and organic matter (Norland 2000), and compaction of soil (Richards et al. 1993) are among the factors that inhibit plant establishment and growth. Many of these conditions also make habitat unsuitable for salamanders, particularly terrestrial salamanders. 
Terrestrial salamanders (ge nera Plethodon and Aneides) lack an aquatic larval stage with young appearing as smaller versions of adults (Grover 1998). Because they are entirely terrestrial, the habitability of terrestrial environments is crucial to their survival. In addition to conditions on the surface of mines, subsurface conditions also are important for salamanders. Salamanders can burrow to depths ranging from several $\mathrm{cm}$ (Taub 1961) to $90 \mathrm{~cm}$ (Grizzell 1949) and 68-98\% of their populations may be found throughout the soil (Taub 1961). The eastern red-backed salamander (Plethodon cinereus), for instance, prefers mature forests with deep soils (Burger 1935). Minesoils are greatly compacted to prevent erosion (Richards et al. 1993) and likely are inhospitable to salamanders.

Mature, mixed deciduous forest is the predominant land cover in West Virginia. Forests cover $78 \%$ of West Virginia, making this state the third most heavily forested in the United States (Griffith and Widmann 2003). Thus, reclaimed mines supporting early successional scrub-shrub and grassland habitats contrast sharply with the surrounding natural landscape and create abrupt edges, which occur at the junction of 2 strongly dissimilar landscape elements where little to no gradation in vegetative structure and composition exists (Yahner 1988). Increased exposure to wind, higher temperatures, and predation associated with open areas (Waldick 1997) may impede dispersal and movement of salamanders. Forests tend to have cooler, moister, and more homogeneous climatic conditions than grasslands (Murcia 1995) and therefore, the native forests should better meet habitat requirements of these salamanders, particularly salamanders from the family Plethodontidae. Salamanders in this family respire through their skin (Green and Pauley 1987) and their skin must remain moist and cool to be effective (Feder 1983).

Several researchers have documented impacts of edge on amphibians (Zimmerman and Rodriguez 1990, Culotta 1995, Marsh and Pearman 1997, Pearman, 1997), but few investigators conducted studies in temperate forests (Perison et al. 1997, deMaynadier and Hunter Jr. 1998, Gibbs 1998a, Spurgeon 2002). Gibbs (1998a) found that forest edges strongly influenced capture rates of the red-spotted newt (Notophthalmus v. viridescens); rates were higher in forest interiors than at forest-road edges or forest-residential edges. In South Carolina, Perison et al. (1997) found herpetofaunal diversity to be lower at edges than in clearcuts and reference forests and suspected this result to be due to high captures of the southern toad (Bufo terrestris), a habitat generalist, at edges. In Maine, deMaynadier and Hunter Jr. (1998) found that abundance of 6 salamander species increased with increasing distance from clearcut edges and that abundance of 3 different amphibian groups (eastern red-backed salamanders, 2 Ambystoma spp. and wood frogs [Rana sylvatica]) were 
affected 25-35 m into forests from clearcut edges. Spurgeon (2002) found that abundance of overall herpetofauna, eastern red-backed salamanders, red-spotted newts, and eastern American toads did not differ between edges and forest interiors in West Virginia, but that wood frog abundance was greater in forests than at edges. Overall herpetofaunal species richness and species diversity did not differ between these 2 treatments. Spurgeon (2002) observed no differences in overall herpetofaunal abundance and abundances of eastern red-backed salamanders, Allegheny Mountain dusky salamanders (Desmognathus ocrophaeus), and Seal Salamanders (D. monticola) among 5 distances from edges into forests: $25 \mathrm{~m}, 50 \mathrm{~m}, 75 \mathrm{~m}, 100 \mathrm{~m}$, and $125 \mathrm{~m}$. No studies to date have supported the conclusions made by deMaynadier and Hunter Jr. (1998) regarding depth of edge effects on salamanders in temperate forests.

Research on edges created by reclaimed mountaintop removal mining poses a unique contribution to edge effect studies because most land management practices that create edge are not of the size or disturbance magnitude as those created by mountaintop mining. On the 3 mountaintop removal mines used for my study, reclaimed mine habitat totaled 1,819 to 2,431 ha (Balcerzak and Wood 2003).

My primary objective was to determine effects of edge created by mountaintop removal mining operations on terrestrial salamanders and on salamanders in general. I examined terrestrial salamanders separately because they only occupy terrestrial habitats; they do not require aquatic habitat during any stage of their life histories. However, because all salamanders share common physiological constraints, I combined terrestrial salamanders with other salamanders and examined impacts on the salamander community collectively. Specifically, I examined abundance relative to distance from edge and relative to the 5 treatments and related salamander presence to environmental variables.

\section{Methods}

Study areas were located on and near 3 mountaintop mines in southwestern West Virginia: Hobet 21, Cannelton, and Dal-Tex, which have reclaimed mine habitat totaling 2,431, 2,180, and 1,819 ha, respectively. Hobet 21 is located in Boone County in the Mud River and Little Coal River Watersheds. Cannelton is on the border of Kanawha and Fayette counties in the Twentymile Creek Watershed. Dal Tex is in Logan County in the Spruce Fork Watershed. Study sites were located within the Allegheny Plateau physiographic province, which is characterized by moderate to strong relief (Strausbaugh and Core 1977). I surveyed 5 treatments: 1) forest, 2) reclaimed grassland, 3) 
reclaimed shrub-pole, 4) edge between forest and reclaimed grassland, and 5) edge between forest and reclaimed shrub-pole.

\section{Native Habitat}

Forests contained 60-80-year-old, second growth, mature hardwoods. Overstory species included tuliptree (Liriodendron tulipifera), red and sugar maples (Acer rubrum and A. saccharum), American sycamore (Plantanus occidentalis), northern red, white, and black oaks (Quercus rubra, Q. alba, and Q. velutina); pignut, bitternut, and shagbark hickories (Carya glabra, C. cordiformis, and C. ovata); American beech (Fagus grandifolia), white ash (Fraxinus americana), and black birch (Betula lenta; Chap 2). Understory species (seedlings, saplings, poles) included black gum (Nyssa sylvatica), flowering dogwood (Cornus florida), ironwood (Carpinus caroliniana), spicebush (Lindera benzoin), and other common hardwood species, including the above-mentioned overstory species (Chap 2). Native soils tended to be deep, well drained, steep (Van Houten et al. 1981, Carpenter 1992, Wolf 1994), and had high litter cover (Chap 2). On Dal-Tex Mine, average

sola depth (combined thickness of $\mathrm{A}, \mathrm{AC}$, and $\mathrm{Bw}$ horizons) was $97 \mathrm{~cm}$ in native soils and all native soils sampled had O horizons (Thomas et al. 2000). These authors did not analyze their results statistically and compared 3 native soil pits to 24 minesoil pits ( 6 pits for each of 4 age classes), but their study is the only one of its kind that I found.

\section{Reclaimed Habitat}

Reclaimed grasslands ranged in age from 12-19 years post-reclamation and were in an arrested stage of succession due to poor soil conditions. Because all of the understory, forest floor and soil were removed with mountaintop removal mining, this mining technique can be classified as a severe disturbance, such as those caused by landslides or glacier retreat (Oliver and Larson 1996). It may take hundreds or thousands of years for reclaimed minesoils to return to pre-disturbance quality and planting options are limited to tolerant species or to species that can rapidly colonize a site and provide essential stability, at least until suitable soil conditions return. The increase in pioneer species coverage and the decline of late successional species in Boone County has been credited to surface mining (Wolf 1994). Patterns of stand development that normally occur after disturbances in forests have not yet begun in these reclaimed grasslands. Forests in the central Appalachians are often dominated by tree regeneration within 5 years post-disturbance clearcuts and within 10 years, an overstory canopy of trees over 20 feet tall is common (Smith, 1977). Twenty years post-disturbance, reclaimed grasslands are not even dominated by tree regeneration. 
Predominant grasses included tall fescue (Festuca arundinacea), orchard grass (Dactylis glomerata), broomsedge (Andropogon virginicus), perennial ryegrass (Lolium perenne), hair grass and redtop (Agrostis scabra and A. stolonifera), timothy (Phleum pratense), and smooth brome (Bromus inermis; Wood and Edwards, 2001). Forbs included birdsfoot trefoil (Lotus corniculatus), alfalfa (Medicago sativa), sericea and bicolor lespedezas (Lespedeza cuneata and L. bicolor), red clover (Trifolium pratense), golden rod (Solidago spp.), sweetclover (Melilotus spp.), aster (Aster spp.), wild lettuce (Lactuca virosa), fleabane (Erigeron canadensis), plantain (Plantago spp.), crownvetch (Coronilla varia), and sedge (Carex spp.; Wood and Edwards, 2001). Grasslands sometimes contained a few shrub species, mostly autumn olive (Elaeagnus umbellata) and multiflora rose (Rosa multiflora; Wood and Edwards, 2001).

Shrub-pole areas contained shrub, sapling, and pole-sized stems and were 7-19 years old. I used vegetation to define these treatments because reclamation age of grassland and shrub-pole treatments overlapped. Predominant shrub-pole species in this treatment included autumn olive, multiflora rose, red maple, American sycamore, tuliptree, European black alder (Alnus glutinosa), blackberry and raspberry (Rubus spp.), sourwood (Oxydendrum arboreum), black locust (Robinia pseudoacacia), and scotch and white pines (Pinus sylvestris and P. strobes; Chap 2). Many of the grass and forb species found in the grassland treatment also occurred in the shrubpole.

Thomas et al. (2000) sampled minesoils on Dal-Tex Mine and found that young minesoils showed little to no profile development, but a 23-year-old minesoil showed some development of weak B horizons. Newly reclaimed minesoils have low organic matter content due to destruction of A horizons (Stephens et al. 2001), but A horizons of minesoils increase with time and can recover in as little as 7 years, according to Thomas et al. (2000), which they attributed to the seeding of grasses and legumes during reclamation. A horizons are the topmost mineral horizons and contain some organic matter. While $\mathrm{O}$ horizons (organic horizons above mineral soil) can be found within minesoils at 2 years of age, minesoils up to 11 years old may have no $\mathrm{O}$ horizon (Thomas et al. 2000). Average sola depth ranged from $12 \mathrm{~cm}$ (2-year-old reclaimed) to $31 \mathrm{~cm}$ (23-year-old reclaimed) on reclaimed soils (Thomas et al. 2000). Surface rock fragment content of minesoils showed no pattern due to age of minesoil; 11-year-old minesoils had a higher content than 23-yearold minesoils, but 2-year-old rock fragment content was lower than that in 23-year-old minesoils (Thomas et al., 2000). Thomas et al. (2000) suspected that these differences were due to variability in blasting and reclamation techniques. 
Native soils had an average water-stable aggregation of $63 \%$ in their surface horizons and $62 \%$ in their subsurface horizons, compared to $31-56 \%$ in surface horizons and $12-54 \%$ in subsurface horizons of minesoils ranging in age from 2 to 23 years. Aggregation is a measure of stability and "expresses the resistance of soil structural aggregates to breakdown when subjected to disruptive processes (Thomas et al., 2000).

\section{Coverboard Transects}

I established 200-m long transects that extended $100 \mathrm{~m}$ into forests and $100 \mathrm{~m}$ into reclaimed habitats (Fig. 1) during the summer of 2001. Transects were perpendicular to edges with sampling stations placed at the edge and at 25- $\mathrm{m}$ increments into each habitat (i.e., $25 \mathrm{~m}, 50 \mathrm{~m}, 75$ $\mathrm{m}$, and $100 \mathrm{~m}$ ). Each transect consisted of 108 coverboards (12 at each 25-m sampling station, 9 sampling stations per transect). Coverboards were approximately $20 \mathrm{~cm}$ x $10 \mathrm{~cm}$ x $1.3-2.5 \mathrm{~cm}$ ), made of untreated, rough sawn wood and arranged in a 3 x 4 pattern. T.K. Pauley (Professor of Herpetology at Marshall University, personal communication) tested various coverboard sizes, designs, and placement schemes. The $3 \times 4$ pattern yielded a higher number of captures, contained a higher percentage of recaptures, and was used 2-6 times more by salamanders in comparison to other patterns. I exercised great care to ensure that each sampling station was at least " $\mathrm{X}$ " $\mathrm{m}$ from all other edges (i.e., boards $75 \mathrm{~m}$ into a forested habitat were at least $75 \mathrm{~m}$ from all non-forest edges).

Forest treatments included a wide range of forest patch shapes and sizes. Patch sizes were as follows: 8.6 ha $(\mathrm{N}=2), 19.7$ ha $(\mathrm{N}=1), 46$ ha $(\mathrm{N}=1), 61$ ha $(\mathrm{N}=1), 69$ ha $(\mathrm{N}=1)$, and 154 ha $(\mathrm{N}=$ 3). The other 9 transects extended into large expanses of contiguous forests. The shortest distance from the $100-\mathrm{m}$ forest sampling station to the other side of a forest patch was $250 \mathrm{~m}$, and this width characterized 2 transects; the maximum distance was $650 \mathrm{~m}$.

I installed 7, 5, and 6 transects on Hobet 21, Dal-Tex, and Cannelton Mines, respectively. More specifically, on Hobet 21 Mine, 4 transects included shrub-pole reclaimed habitat and 3 went into grassland habitat. On Dal-Tex Mine, all 5 transects traversed shrub-pole reclaimed habitat. Cannelton Mine contained 3 transects with shrub-pole reclaimed habitat and 3 with grassland reclamation. Thus, 12 transects covered shrub-pole reclaimed areas and 6 covered grassland reclamation.

For coverboard placement, I scraped away leaf litter so that each board made contact with soil (Droege et al. 1997, Yahner et al. 2001) and then used available surrounding natural substrate to scatter over the boards. I checked under coverboards for salamanders once per month (Fellers and 
Drost 1994, Droege et al. 1997, Rodewald and Yahner 1999) in September and October 2001 and in April-June and September-November 2002. I sampled during spring and fall because terrestrial salamander surface densities are greatest during these seasons (Droege et al. 1997). I checked each transect 8 times. On any given day of checking, all treatments were represented (i.e., I checked entire transects, which contained reclaimed, edge, and forest habitats) to eliminate temporal effects among treatments. I did not conduct surveys during heavy rain to avoid introducing a variable that may influence captures.

I identified salamanders to species and toe-clipped to identify recaptures. I minimized possibility of dehydration associated with handling animals by rehydrating them with stream water (modified from Fellers et al. 1994). To minimize handling time and stress to the animal, I measured SVL after placing individuals in resealable plastic bags (Droege et al. 1997). I used different bags with each individual to reduce the likelihood of disease transmission among individuals (Fellers et al. 1994).

\section{Environmental Conditions}

During the first 2 sampling periods (September and October 2001), I did not record environmental variables. During the remaining sampling periods, I recorded air and soil temperatures and time of day at 3 transect locations: 100-m reclaimed, 0 - $\mathrm{m}$ edge, and 100-m forest, I measured air temperature $1 \mathrm{~m}$ above the ground (Jung, 2002) using a -30 to $50{ }^{\circ} \mathrm{C}$ Pocket Thermometer (Ben Meadows Company) and soil temperature $3 \mathrm{~cm}$ below the soil surface with a REOTEMP Heavy Duty Soil Thermometer (Ben Meadows Company).

\section{Statistical Analyses}

Total trap effort equaled the number of undisturbed 25-m sampling stations per transect. A loss of trap effort sometimes occurred because boards at a sampling station would be scattered or missing. Because each of the 18 transects had $925-\mathrm{m}$ sampling stations and I checked each transect 8 times, I checked a total number of 129625 - m sampling stations during the course of the study. Of these 1296 25-m sampling stations, 15 were inoperable at some point, which was only $1 \%$ loss of trap effort. These 15 sampling stations were not included in statistical analyses.

To examine edge effect on salamanders, I used Poisson regression (PROC GENMOD in the Statistical Analysis System (SAS) software; SAS Institute 2000) because count data tend to have a Poisson distribution. The regression model included number of captures as the dependent variable; independent variables were distance and a block on treatment by mine by habitat. Because the 
effect of distance may not have been a linear function, each distance value was tested up to the fifth power.

The prediction equation included all values up to this fifth power and summed them to determine 1 capture value at each distance. I then used contrast statements to examine all pairwise comparisons of 25-m sampling stations from the edge to 100-m into the forest (Cody and Smith 1997) to determine which distances differed in predicted captures.

To examine differences in salamander abundance among the 5 treatments, I used repeated measures ANOVA with PROC GENMOD (SAS Institute 2000). In this model, number of captures was the dependent variable while mine, treatment, sampling period, and the interaction between sampling period and treatment were the independent variables. I used a REPEATED statement in PROC GENMOD to test for an interaction between transect and treatment (SAS Institute 2000). When differences occurred among treatments, I used the least significant means multiple comparison test to determine which treatments differed (SAS Institute 2000). To test whether captures differed between forest patches and contiguous forest tracts, I also used repeated measure ANOVA with PROC GENMOD similar to the model used to test for differences in salamander abundance among treatments (SAS Institute 2000).

I used weighted logistic regression to examine relationships between captures and temperatures of air and soil and between captures and major habitat group (forest, edge, reclaimed). Captures were converted to presence-absence data and were weighted to reflect sampling effort (i.e., 4 for forest and reclaimed habitats and 1 for edge). I blocked for sampling period by mine and compared each variable (air, soil, habitat) using separate models. I then used contrast statements to compare captures among habitats.

I conducted all analyses on 2 datasets: terrestrial salamander data and all salamander data. I denoted these response groups by use of capital letters with TERRESTRIAL for terrestrial salamanders and ALL for all salamanders (terrestrial and non-terrestrial) throughout the remainder of the text to avoid ambiguity for readers. I analyzed data using Statistical Analysis System 8.1 (SAS Institute 2000) at an alpha level of 0.10. Use of a higher alpha level is justified when researching conservation issues to avoid making a type II error (Askins et al. 1990; Caughley and Gunn 1995). 


\section{Results}

During coverboard checks, I captured 51 salamanders (including 1 recapture of the southern ravine salamander [Plethodon richmondi]) of 7 species (Table 1). I also captured 2 snake species, including the northern ring-necked snake (Diadophis punctatus edwardsii; $\mathrm{N}=2$ ) and the eastern ratsnake (Elaphe alleghaniensis; $\mathrm{N}=1$ ). TERRESTRIAL (Plethodon spp.) accounted for $76.5 \%$ of all captures and included 4 species: the eastern red-backed salamander, the northern slimy salamander (P. glutinosus), the Cumberland Plateau salamander (P. kentucki), and the southern ravine salamander (Table 1). Most TERRESTRIAL captures were in the forested treatment (Table 2). The remaining captures occurred within the shrub-pole habitat (Table 2) during fall months (Table 3) when coverboards were frequently checked during light rains.

I found the most frequently captured species, the eastern red-backed salamander (Table 1), primarily in the forested treatment (Table 2). Although this species was captured on only 1 mine (Hobet 21), it was widely distributed being captured on 5 of 7 transects.

The southern ravine salamander was the second most frequently captured species (Table 1). Similar to the eastern red-backed salamander, I captured most southern ravine salamanders in the forested treatment (Table 2). The only non-forest capture of this species occurred at an edge bordering reclaimed shrub-pole and forest. This species was captured on all 3 mines (Table 1).

Non-terrestrial species of salamanders accounted for $23.5 \%$ of all captures. They included 3 species of 3 different families and genera (Ambystoma, Eurycea, and Notophthalmus). The red efts, the juvenile terrestrial form of the red-spotted newt, represented the most commonly captured nonterrestrial species. I captured the majority of red efts in the forest far from edges $(\mathrm{N}=5,63 \%$;

Table 2). The remaining 3 captures were on the edge or at $25-\mathrm{m}$ into a reclaimed habitat.

Captures varied over the sampling period for TERRESTRIAL (Table 3; Wald $\chi^{2}=21.41, P$ $=0.003$ ), but not ALL (Table 4; Wald $\chi^{2}=10.66, P=0.15$ ). There was no interaction between sampling period and treatment for either group (TERRESTRIAL: Wald $\chi^{2} .=26.24, P=0.56$; ALL: Wald $\chi^{2}=35.58, P=0.15$ ).

\section{Edge Effects}

TERRESTRIAL.-I found a fifth order relationship between distance and captures (Wald $\chi^{2}=7.84$, $P=0.005)$ for TERRESTRIAL. Captures increased with increasing distance from reclaimed mine habitat into forests (Figure 2).

TERRESTRIAL captures were higher at 25- $\mathrm{m}$ into the forest than at edges (edges of reclaimed grasslands and reclaimed shrub-pole combined), but there were no differences in captures 
between edges and 50-m (Tables 5 and 6). These results indicate that TERRESTRIAL were affected at a minimum distance of 25- $\mathrm{m}$ from a reclaimed edge on mountaintop removal mines. Based on a visual interpretation of the data (Fig. 2), TERRESTRIAL captures continued to increase at sampling stations further from edges. I captured more TERRESTRIAL salamanders at 75-m into forests than at edges (Table 5). The lower number of captures at 50-m into forests may be a relict of small sample size rather than a true representation of the data.

ALL. - There was a fifth order relationship between distance and captures $\left(\right.$ Wald $\chi^{2}=7.64, P=$ 0.006) for ALL. As was true for TERRESTRIAL, captures of ALL increased with increasing distance from reclaimed mine habitat into the forest (Figure 3).

I found no differences in captures between edges (edges of reclaimed grasslands and reclaimed shrub-pole combined) and 25-m distances (Tables 5 and 6) for ALL. Therefore, although captures increased with increasing distance from edge, I was unable to determine to what distance edge effects occurred. A graphical representation of the data (Fig. 3), suggests that ALL captures also appeared to increase at sampling stations further into forests. Furthermore, I captured more ALL at 75-m and at 100- $\mathrm{m}$ into forests than at edges (Table 5). As with TERRESTRIAL, captures at 50-m into forests are inconsistent with the general pattern seen along transects, which again may be may be an artifact of small sample size rather than a true representation of the data.

\section{Habitat Use}

TERRESTRIAL.-I found differences in captures of TERRESTRIAL due to treatment $\left(\right.$ Wald $\chi^{2}=$ 13.86, $P=0.008$; Table 7). Forested treatments supported higher relative abundance than reclaimed grasslands $\left(\chi^{2}=12.10, P=0.0005\right)$, reclaimed shrub-pole habitats $\left(\chi^{2}=6.43, P=0.01\right)$, edge between reclaimed grasslands and forests $\left(\chi^{2}=10.64, P=0.001\right)$, and edge between reclaimed shrub-pole habitats and forests $\left(\chi^{2}=9.65, P=0.002\right)$. Captures within the 4 non-forest treatments did not differ among each other $(P>0.10)$. Relative abundance did not differ between forest patches $($ Mean \pm SE: $0.053 \pm 0.016)$ and contiguous forest tracts $\left(\right.$ Mean \pm SE: $0.052 \pm 0.017 ; \chi^{2}=$ $0.02, P=0.87)$.

ALL.- I found differences in captures for ALL due to treatment ( Wald $\chi^{2}=15.10, P=0.005$; Table 7). As with TERRESTRIAL, forested habitats supported higher relative abundance than reclaimed grasslands $\left(\chi^{2}=9.21, P=0.002\right)$, reclaimed shrub-pole habitats $\left(\chi^{2}=7.97, P=0.005\right)$, edge between reclaimed grasslands and forests $\left(\chi^{2}=9.31, P=0.002\right)$, and edge between reclaimed 
shrub-pole habitats and forests $\left(\chi^{2}=14.38, P=0.0001\right)$. Captures within the 4 non-forest treatments did not differ among each other $(P<0.10)$.

Habitat categories affected relative abundance of TERRESTRIAL $\left(\right.$ Wald $\left.\chi^{2}=48.38, P<0.0001\right)$ and of ALL (Wald $\left.\chi^{2}=47.64, P<0.0001\right)$. TERRESTRIAL captures were lower in reclaimed habitats than edges (Wald $\chi^{2}=3.00, P=0.08$ ), in reclaimed habitats than forests ( Wald $\chi^{2}=34.18$, $P<0.0001)$, and in edges than forests $\left(\right.$ Wald $\left.\chi^{2} .=12.24, P=0.0005\right)$. Similarly, ALL captures were lower in reclaimed habitats then edges ( Wald $\chi^{2}=6.19, P=0.01$ ), in reclaimed habitats than forests $\left(\right.$ Wald $\left.\chi^{2}=34.32, P<0.0001\right)$, and in edges than forests $\left(\right.$ Wald $\left.\chi^{2} .=15.38, P<0.0001\right)$. Relative abundance did not differ between forest patches (Mean \pm SE: $0.067 \pm 0.018$ ) and contiguous forest tracts (Mean $\pm \mathrm{SE}: 0.063 \pm 0.017 ; \chi^{2}=0.00, P=0.99$ ).

\section{Temperature}

Soil temperature was inversely related to TERRESTRIAL captures ( Wald $\chi^{2} .=3.60, P=0.06$ ), but not to ALL ( Wald $\chi^{2}=0.84, P=0.36$ ). Air temperature had no effect on captures for either salamander group (TERRESTRIAL: Wald $\chi^{2}=0.02, P=0.90 ;$ ALL: Wald $\chi^{2}=0.03, P=0.85$ ).

Soil temperatures did not differ among the habitat groups $\left(\right.$ Wald $\left.\chi^{2}=0.03, P=0.99\right)$. Air temperatures also did not differ with respect to habitat (ALL: Wald $\chi^{2}=0.47, P=0.79$ ).

\section{Discussion}

There is clearly an edge effect on both TERRESTRIAL and ALL due to reclaimed mine treatments. Depths of edge effects for TERRESTRIAL $(25-<50 \mathrm{~m})$, were similar to those reported by deMaynadier and Hunter $(25-35 \mathrm{~m} ; 1998)$. In my study, ALL were not affected as far $(<25 \mathrm{~m})$, but did appear to be significantly impacted by edges on mountaintop removal mines. Few salamanders were captured in reclaimed habitats. The majority in reclaimed habitats were in shrub/pole and generally within $50 \mathrm{~m}$ of the edge. Relative abundance peaked at $75 \mathrm{~m}$ from edges in forests and maintained high levels at $100 \mathrm{~m}$. Characteristics typical of edges that likely contributed to the reduced abundance of salamanders near edges includes increased sunlight and wind and reduced soil moisture and shade (Noss and Csuti 1997).

Reclaimed mine habitats and edges between these habitats and forests were less favorable for occupancy by both TERRESTRIAL and ALL. While both salamander groups used reclaimed mine habitats, they were more abundant in forested treatments over all other treatments. Although there were no statistical differences among non-forested treatments for captures, trends in mean captures adjusted for sampling effort suggested that reclaimed grasslands were less suitable for 
colonization by salamanders, particularly TERRESTRIAL, than reclaimed shrub-pole habitat. One hundred percent of grassland captures and $40 \%$ of shrub-pole captures were at edges or $25-\mathrm{m}$ from the edge into reclaimed treatments.

Reclaimed shrub-pole treatments supported more trees of small dbh (saplings and poles) and larger dbh (up to $38 \mathrm{~cm}$ ) than reclaimed grasslands (Chap 2). Additionally, reclaimed shrub-pole treatments had more litter cover, more canopy cover from shrubs, saplings, understory trees, and subcanopy trees, and greater height of herbaceous vegetation than reclaimed grasslands (Chap 2). Forested treatments had more canopy cover from codominant and dominant trees, greater numbers of trees 8.1-38 cm dbh, and more woody debris than did reclaimed treatments (Chap 2). Shade reduces evaporative water loss from soils and woody debris provides shelter from predators and adverse climate conditions (Waldick 1997). These conditions favor salamanders, as they are limited in mobility due to anatomical (small in size) and physiological (require moisture) constraints (Green and Pauley 1987). These characteristics limit their ability to traverse or move into open areas like reclaimed grasslands and reclaimed shrub-pole treatments.

Soil quality also likely influenced use of reclaimed habitats by salamanders in this study. Soil compaction and high rock content of reclaimed minesoils probably prevents or deters salamanders from burrowing in minesoils. Up to 5 years may pass since time of initial disturbance before thin A horizons form on reclaimed mine surfaces (Haering et al. 1993; Roberts et al. 1988a, $b$; Thomas and Jansen 1985). As this is the horizon where most invertebrates can be found, its removal also likely reduces prey availability for salamanders. While thin O horizons (organic horizons above mineral soil) can be found within minesoils at 2 years of age, minesoils up to 11 years old may have no O horizon (Thomas et al. 2000). Organic matter improves water-holding capacity of soils (Richards et al. 1993); thus, its reduction may further exacerbate dryness of soils from increased exposure to sun and wind on reclaimed mountaintop removal mines. Myers and Klimstra (1963) also found low numbers of salamanders on strip-mines in southern Illinois and attributed this to the low organic content characteristic of minesoils.

Although I found differences in captures of TERRESTRIAL and ALL but no differences in soil temperatures among reclaimed, edge, and forested habitats, soil temperature was negatively related to captures of TERRESTRIAL. Soil temperatures at 100-m reclaimed, edge, and 100-m forested were as follows (Mean $\pm \mathrm{SE}$ ): $16.86 \pm 0.66,15.68 \pm 0.64$, and $14.22 \pm 0.66$. Thus, while not statistically significant, the $1-2^{\circ}$ temperature difference among treatments may be biologically significant to TERRESTRIAL. As ectotherms, salamanders often control body temperatures by 
moving among microhabitats (Stebbins and Cohen 1995). TERRESTRIAL in particular are greatly constrained by temperature because they require cool and moist conditions (Stebbins and Cohen 1995). Thus, they modify their behavior to accommodate these restrictions by selecting environments of preferred temperatures (Stebbins and Cohen 1995).

The proportion of eastern red-backed salamanders captured in closed-canopy transects (71.4\%) by deMaynadier and Hunter (1998) was similar to the proportion that I found (69.2\%). deMaynadier and Hunter (1998) found the eastern red-backed salamander to be the species considered most sensitive to edge in their study, even though they found over 60 animals in clearcuts. They suspected that these individuals, most of which were juveniles, were displaced from forested habitats by conspecific terrestrial adults; Gabor and Jaeger (1995) showed that the eastern red-backed salamander will aggressively defend territories of higher quality. Conversely, Ash (1997) documented the Jordan's salamander (Plethodon jordani) adults as the primary colonizers of clearcuts and suggested that they may be better equipped to deal with the harsher environments of regenerating clearcuts than juveniles. Likewise, I found that all of the eastern red-backed salamander captures in reclaimed treatments were adults. Perhaps the 8 eastern red-backed salamanders captured at reclaimed and edge treatments in this study were competitively inferior to adults from forested treatments; 10 of 13 eastern red-backed salamanders captured in forests were adults.

Ash (1997) and Petranka et al. (1993) studied effects of clearcutting on salamanders. Time for populations to return to pre-clearcutting levels was predicted by Ash (1997) to take 20-24 years, whereas Petranka et al. (1993) anticipated a recovery period of 50-70 years. Duguay and Wood (2002) found that salamander populations in clearcuts in West Virginia were similar to mature forests within 15 years. Populations on the mine sites that I sampled have not yet recovered 10-19 years post-disturbance. While clearcutting is a harvesting practice used since the $19^{\text {th }}$ century, mountaintop removal mining is a relatively new mining technique used in West Virginia only since the late 1960s. Thus, no data of its impacts on salamanders are available to compare. However, given that grasslands have not started the stand initiation stage of forest development, salamanders were not afforded the benefits of increasing vertical structure and leaf litter cover that comes with forest succession. Although captures were not statistically different between grasslands and shrubpole treatments, I did capture more salamanders per unit effort in shrub-pole than in grasslands. Perhaps the greater vertical structure improved the microclimate and soil conditions in reclaimed shrub-pole habitats and presented more tolerable conditions for salamanders. 
Silvicultural edges may be only temporary at the stand scale because forest succession gradually lessens the contrast between disturbed areas and adjacent mature forest (DeGraaf 1992). However, although such effects may only be transient, they may not reflect large-scale, cumulative impacts on salamanders, such as those at a landscape or ecosystem level (deMaynadier and Hunter Jr. 1998). Because edges created by mountaintop removal mining are slow to disappear, edge effects from reclamation on salamanders may be even more serious than those created by silvicultural or logging practices. Furthermore, strength of edge effects are often positively related to degree of contrast between the adjoining habitats (Noss and Csuti 1997), which is considerable on these reclaimed mines. As mountaintop removal mining continues in the southern Appalachians, the total amount of edge in this landscape will increase over time and will result in a decrease in salamander populations due to edge effects as well as outright loss of forest habitat. 
Table 1. Number of salamanders captured $(\mathrm{N})$ per species, proportion that each species contributed to total captures, and number of mines and transects where each species was captured in a reclaimed mountaintop removal mine landscape in southern West Virginia, 2001-2002.

\begin{tabular}{|c|c|c|c|c|}
\hline Species & $\mathrm{N}$ & $\begin{array}{c}\% \text { of } \\
\text { Captures }\end{array}$ & $\begin{array}{c}\text { No. of Mines } \\
\text { Where Captured }\end{array}$ & $\begin{array}{l}\text { No. of Transects } \\
\text { Where Captured }\end{array}$ \\
\hline \multicolumn{5}{|l|}{$\begin{array}{l}\text { Terrestrial Salamanders } \\
\text { (Obligate Terrestrial Only) }\end{array}$} \\
\hline $\begin{array}{l}\text { Eastern Red-backed Salamander } \\
\text { (Plethodon cinereus) }\end{array}$ & 26 & 51 & 1 & 5 \\
\hline $\begin{array}{l}\text { Northern Slimy Salamander } \\
\text { (P. glutinosus) }\end{array}$ & 1 & 2 & 1 & 1 \\
\hline $\begin{array}{l}\text { Cumberland Plateau Salamander } \\
(P . \text { kentucki) }\end{array}$ & 1 & 2 & 1 & 1 \\
\hline $\begin{array}{l}\text { Southern Ravine Salamander } \\
\text { (P. richmondi) }\end{array}$ & 11 & 21.6 & 3 & 7 \\
\hline \multicolumn{5}{|l|}{ Other Salamanders } \\
\hline $\begin{array}{l}\text { Spotted Salamander } \\
\text { (Ambystoma maculatum) }\end{array}$ & 1 & 2 & 1 & 1 \\
\hline $\begin{array}{l}\text { Southern Two-lined Salamander } \\
\text { (Eurycea cirrigera) }\end{array}$ & 3 & 5.9 & 2 & 3 \\
\hline $\begin{array}{l}\text { Red Eft } \\
\text { (Notophthalmus v. viridescens) }\end{array}$ & 8 & 15.7 & 3 & 5 \\
\hline All Salamanders & 51 & 100 & 3 & 13 \\
\hline
\end{tabular}


Table 2. Number of salamanders captured at 25-m increments along 200-m transects that spanned from 0-m at edges (E) to 100-m into reclaimed (R) (grassland: GR) and shrub-pole: S-P) and forested (F) habitats.

\begin{tabular}{|c|c|c|c|c|c|c|c|c|c|c|}
\hline \multirow[b]{2}{*}{ Species } & \multirow{2}{*}{$\begin{array}{l}\text { Reclaimed } \\
\text { Treatment } \\
\end{array}$} & \multicolumn{9}{|c|}{ Transect Increments } \\
\hline & & $100 \mathrm{R}$ & $75 \mathrm{R}$ & $50 \mathrm{R}$ & $25 \mathrm{R}$ & $0 \mathrm{E}$ & $25 \mathrm{~F}$ & $50 \mathrm{~F}$ & $75 \mathrm{~F}$ & $100 \mathrm{~F}$ \\
\hline Terrestrial Salamanders & GR & & & & & 1 & 2 & 2 & 2 & 2 \\
\hline (Obligate Terrestrial Only) & $\underline{\mathrm{S}-\mathrm{P}}$ & 1 & 1 & 3 & & 3 & 7 & 1 & 9 & 5 \\
\hline \multirow{2}{*}{$\begin{array}{l}\text { Eastern Red-backed Salamander } \\
\text { (Plethodon cinereus) }\end{array}$} & GR & & & & & 1 & & & & 1 \\
\hline & $\underline{\mathrm{S}-\mathrm{P}}$ & 1 & 1 & 3 & & 2 & 5 & 1 & 7 & 4 \\
\hline \multirow{2}{*}{$\begin{array}{l}\text { Northern Slimy Salamander } \\
\text { (P. glutinosus) }\end{array}$} & GR & & & & & & & & 1 & \\
\hline & $\underline{\mathrm{S}-\mathrm{P}}$ & & & & & & & & & \\
\hline \multirow{2}{*}{$\begin{array}{l}\text { Cumberland Plateau Salamander } \\
\text { (P. kentucki) }\end{array}$} & GR & & & & & & 1 & & & \\
\hline & $\underline{\mathrm{S}-\mathrm{P}}$ & & & & & & & & & \\
\hline \multirow{2}{*}{$\begin{array}{l}\text { Southern Ravine Salamander } \\
\text { (P. richmondi) }\end{array}$} & GR & & & & & & 1 & 2 & 1 & 1 \\
\hline & $\underline{\mathrm{S}-\mathrm{P}}$ & & & & & 1 & 2 & & 2 & 1 \\
\hline \multirow[t]{2}{*}{ Other Salamanders } & GR & & & & 2 & 1 & & & 3 & 1 \\
\hline & $\underline{\mathrm{S}-\mathrm{P}}$ & & & 1 & 1 & & & & & 3 \\
\hline \multirow{2}{*}{$\begin{array}{l}\text { Spotted Salamander } \\
(\text { Ambystoma maculatum) }\end{array}$} & GR & & & & & & & & & \\
\hline & $\underline{\mathrm{S}-\mathrm{P}}$ & & & 1 & & & & & & \\
\hline \multirow{2}{*}{$\begin{array}{l}\text { Southern Two-lined Salamander } \\
\text { (Eurycea cirrigera) }\end{array}$} & GR & & & & 1 & & & & 1 & 1 \\
\hline & $\underline{\mathrm{S}-\mathrm{P}}$ & & & & & & & & & \\
\hline \multirow{2}{*}{$\begin{array}{l}\text { Red Eft } \\
\text { (Notophthalmus v. viridescens) }\end{array}$} & GR & & & & 1 & 1 & & & 2 & \\
\hline & $\underline{\mathrm{S}-\mathrm{P}}$ & & & & 1 & & & & & 3 \\
\hline \multirow{2}{*}{$\begin{array}{l}\text { All Salamanders } \\
\text { (Includes Obligate Terrestrial) } \\
\end{array}$} & GR & & & & 2 & 2 & 2 & 2 & 5 & 3 \\
\hline & S-P & 1 & 1 & 4 & 1 & 3 & 7 & 1 & 9 & 8 \\
\hline
\end{tabular}


Table 3. Terrestrial salamanders (obligate terrestrial only) captured at 25-m increments along 200-m transects that spanned from $0-\mathrm{m}$ at edges $(\mathrm{E})$ and $100-\mathrm{m}$ into both reclaimed mountaintop removal mine habitats (R) and forested habitat (F) in southern West Virginia, 2001-2002.

\begin{tabular}{|c|c|c|c|c|c|c|c|c|c|c|c|}
\hline \multirow[b]{2}{*}{ Month } & \multirow[b]{2}{*}{ Check\# } & \multirow[b]{2}{*}{ Total Captures } & \multicolumn{9}{|c|}{ Transect Increments } \\
\hline & & & $100 \mathrm{R}$ & $75 \mathrm{R}$ & $50 \mathrm{R}$ & $25 \mathrm{R}$ & $0 \mathrm{E}$ & $25 \mathrm{~F}$ & $50 \mathrm{~F}$ & $75 \mathrm{~F}$ & $100 \mathrm{~F}$ \\
\hline Sep & 1 & 0 & & & & & & & & & \\
\hline Oct & 2 & 6 & & & 2 & & & 1 & & & 3 \\
\hline Apr & 3 & 4 & & & & & 1 & 2 & & 1 & \\
\hline May & 4 & 1 & & & & & & & 1 & & \\
\hline Jun & 5 & 2 & & & & & & & $1^{1}$ & 1 & \\
\hline Sep and Oct & 6 & 8 & & & & & & 1 & 1 & 4 & 2 \\
\hline Oct & 7 & 13 & 1 & 1 & & & 1 & 4 & & 5 & 1 \\
\hline Nov & 8 & 5 & & & 1 & & 2 & 1 & & & 1 \\
\hline
\end{tabular}

${ }^{1}$ This individual is a recapture.

Table 4. All salamanders (includes obligate terrestrial) captured at 25-m increments along 200-m transects that spanned from $0-\mathrm{m}$ at edges $(\mathrm{E})$ and $100-\mathrm{m}$ into both reclaimed mountaintop removal mine habitats (R) and forested habitat (F) in southern West Virginia, 2001-2002.

\begin{tabular}{cccccccccccc}
\hline & & \multicolumn{8}{c}{ Transect Increments } \\
\cline { 3 - 10 } Month & Check \# & Total Captures & 100R & $75 \mathrm{R}$ & $50 \mathrm{R}$ & $25 \mathrm{R}$ & $0 \mathrm{E}$ & $25 \mathrm{~F}$ & $50 \mathrm{~F}$ & $75 \mathrm{~F}$ & $100 \mathrm{~F}$ \\
\hline Sep & 1 & 3 & & & & & & & & 1 & 2 \\
Oct & 2 & 6 & & & 2 & & & 1 & & & 3 \\
Apr & 3 & 6 & & & 1 & & 1 & 2 & & 2 & \\
May & 4 & 2 & & & & 1 & & & 1 & & \\
Jun & 5 & 4 & & & & & 1 & & 1 & 1 & 1 \\
Sep and Oct & 6 & 11 & & & & 1 & & 1 & 1 & 5 & 3 \\
Oct & 7 & 13 & 1 & 1 & & & 1 & 4 & & 5 & 1 \\
Nov & 8 & 6 & & & 1 & 1 & 2 & 1 & & & 1 \\
\hline
\end{tabular}

${ }^{1}$ This individual is a recapture. 
Table 5. Terrestrial salamander (obligate terrestrial only) and all salamander (includes obligate terrestrial salamanders) comparisons of relative abundance between coverboard sampling stations spaced every $25-\mathrm{m}$ along transects spanning from mountaintop removal mine edges $(0 \mathrm{~m})$ of reclaimed grassland and reclaimed shrub-pole habitat into forested habitats $(100 \mathrm{~m})$ in southern West Virginia, 2001-2002.

\begin{tabular}{lccccc}
\hline & \multicolumn{2}{c}{ Terrestrial Salamanders } & & \multicolumn{2}{c}{ All Salamanders } \\
\cline { 2 - 3 } \cline { 5 - 5 } Distance Comparisons & $\chi^{2}$ & $P$ & & $\chi^{2}$ & $P$ \\
\hline 0 and 25 & 3.28 & 0.07 & & 1.63 & 0.20 \\
0 and 50 & 0.13 & 0.72 & & 0.41 & 0.52 \\
0 and 75 & 6.64 & 0.01 & & 8.36 & 0.004 \\
0 and 100 & 1.28 & 0.26 & & 3.79 & 0.05 \\
25 and 50 & 4.75 & 0.03 & & 3.68 & 0.06 \\
25 and 75 & 0.59 & 0.44 & & 2.62 & 0.11 \\
25 and 100 & 0.46 & 0.50 & & 0.46 & 0.50 \\
50 and 75 & 8.67 & 0.003 & & 12.49 & 0.001 \\
50 and 100 & 2.24 & 0.13 & & 6.70 & 0.01 \\
75 and 100 & 2.08 & 0.15 & & 0.89 & 0.35 \\
\hline
\end{tabular}

Table 6. Terrestrial salamanders (obligate terrestrial only) and all salamanders (includes obligate terrestrial) captured along a $200-\mathrm{m}$ transect traversing reclaimed grassland and reclaimed shrub-pole habitats (-) and forested habitats (+) in southern West Virginia, 2001-2002; edge is denoted by 0.

\begin{tabular}{|c|c|c|c|c|}
\hline \multirow[b]{2}{*}{ Distance } & \multicolumn{2}{|c|}{ Terrestrial Salamanders } & \multicolumn{2}{|c|}{ All Salamanders } \\
\hline & Mean & $\mathrm{SE}$ & Mean & $\mathrm{SE}$ \\
\hline-100 & 0.007 & 0.007 & 0.007 & 0.007 \\
\hline-75 & 0.007 & 0.007 & 0.007 & 0.007 \\
\hline-50 & 0.021 & 0.012 & 0.028 & 0.014 \\
\hline-25 & 0.000 & 0.000 & 0.022 & 0.012 \\
\hline 0 & 0.028 & 0.014 & 0.035 & 0.015 \\
\hline 25 & 0.063 & 0.025 & 0.063 & 0.025 \\
\hline 50 & 0.021 & 0.012 & 0.021 & 0.012 \\
\hline 75 & 0.077 & 0.032 & 0.099 & 0.035 \\
\hline 100 & 0.049 & 0.018 & 0.077 & 0.023 \\
\hline
\end{tabular}


Table 7. Relative abundance of terrestrial salamander (obligate terrestrial only) and all salamander (includes obligate terrestrial) captures among treatments in a reclaimed mountaintop removal mine landscape in southern West Virginia, 2001-2002. Within a column, means with the same letter do not differ (alpha=0.1).

\begin{tabular}{lcccccc}
\hline & \multicolumn{2}{c}{ Terrestrial Salamanders } & & \multicolumn{2}{c}{ All Salamanders } \\
\cline { 6 - 7 } \cline { 5 - 6 } Habitat & Mean & SE & & Mean & SE \\
\hline Reclaimed Grassland & $0.000 \mathrm{~B}$ & & 0.000 & & $0.011 \mathrm{~B}$ & 0.008 \\
Reclaimed Shrub-pole & $0.013 \mathrm{~B}$ & & 0.006 & & $0.018 \mathrm{~B}$ & 0.007 \\
Edge between Reclaimed Grassland and Forest & & $0.021 \mathrm{~B}$ & 0.021 & & $0.043 \mathrm{~B}$ & 0.030 \\
Edge between Reclaimed Shrub-pole and Forest & $0.031 \mathrm{~B}$ & 0.018 & & $0.031 \mathrm{~B}$ & 0.018 \\
Forest & $0.053 \mathrm{~A}$ & 0.011 & & $0.065 \mathrm{~A}$ & 0.012 \\
\hline
\end{tabular}


$100 \mathrm{~m} \quad 75 \mathrm{~m} \quad 50 \mathrm{~m} \quad 25 \mathrm{~m} \quad$ Edge $\quad 25 \mathrm{~m} \quad 50 \mathrm{~m} \quad 75 \mathrm{~m} \quad 100 \mathrm{~m}$

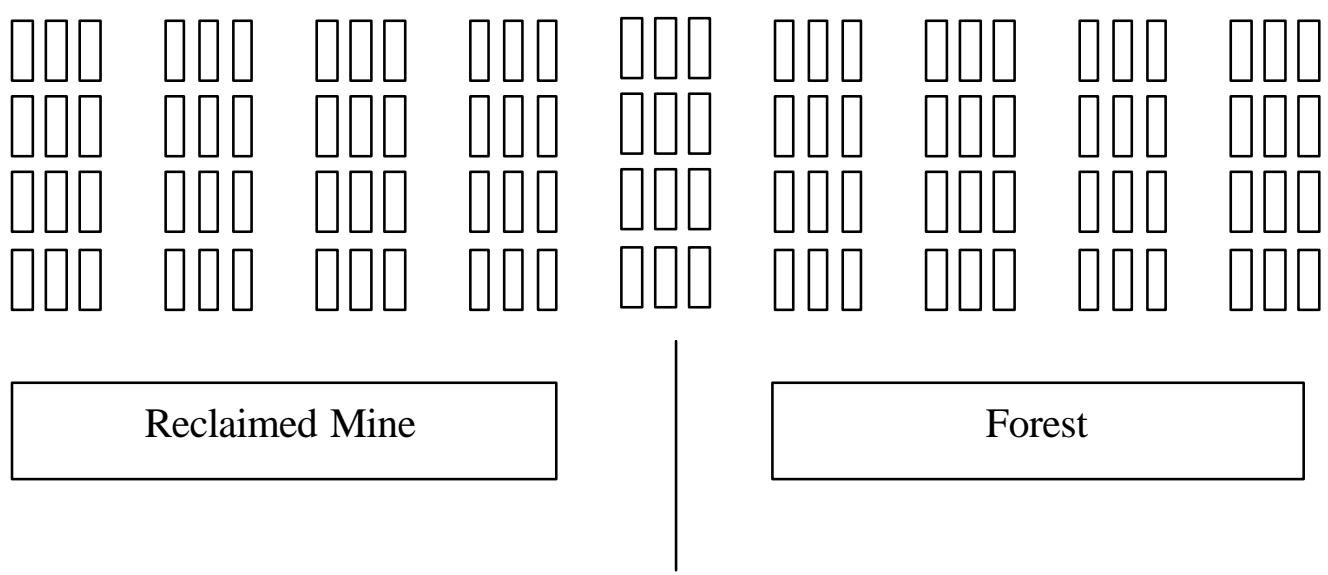

Figure 1. Placement of coverboard transects relative to reclaimed mine and forested treatments in a reclaimed mountaintop removal mine landscape in southern West Virginia, 2001-2002. 


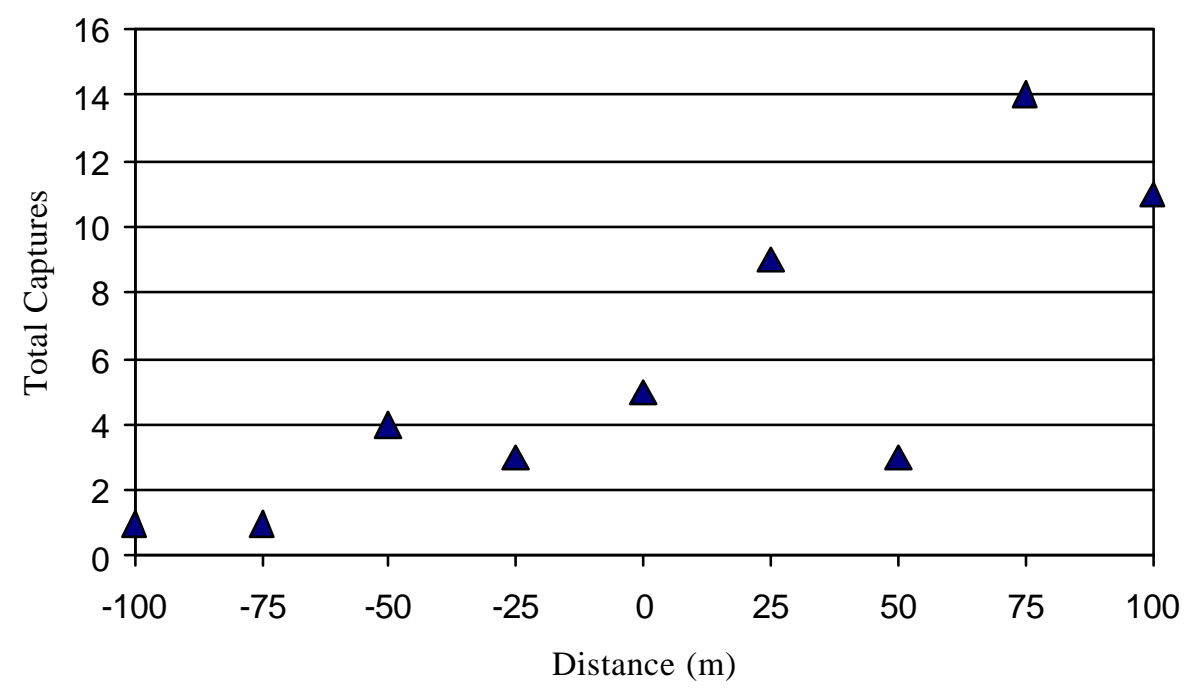

Figure 2. Terrestrial salamander captures (obligate terrestrial only) along a 200- $\mathrm{m}$ transect traversing reclaimed mountaintop removal mine $(-)$ and forested $(+)$ habitats in a reclaimed mountaintop removal mine landscape in southern West Virginia, 2001-2002; edge is denoted by 0 $\mathrm{m}$.

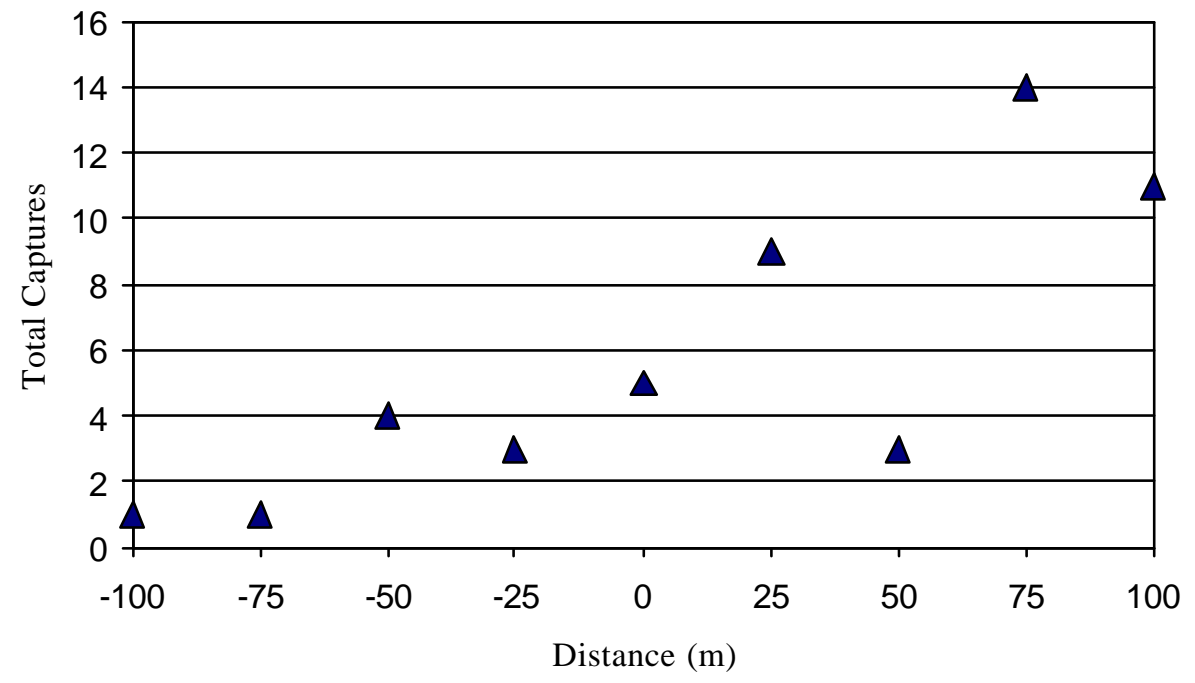

Figure 3. All salamander (includes obligate terrestrial) captures along a 200-m transect traversing reclaimed mountaintop removal mine (-) and forested (+) habitats in a reclaimed mountaintop removal mine landscape in southern West Virginia, 2001-2002; edge is denoted by $0 \mathrm{~m}$. 


\section{Appendix 1}

Over the 3 years of sampling (2000-2003), we captured or observed 1817 individuals with drift fence arrays and incidental sightings for the pre- and post-mining treatment component of this study. Of a possible 59 species expected to occur in the study area, we encountered 43 (Appendix 1). The 43 species included 13 salamander species, 10 toad and frog species, 3 lizard species, 14 snake species, and 3 turtle species.

The West Virginia Wildlife Diversity Program and Natural Heritage Program assigns state ranks to rare, threatened, and endangered animals and plants based on documented occurrences and distributions of species within the state, habitat requirements of species, and threats to existing populations (West Virginia Division of Natural Resources 2003). We documented the presence of 8 species with special status: Northern Leopard Frog, Northern Red Salamander, Little Brown Skink, Eastern Wormsnake (Carphophis a. amoenus), Timber Rattlesnake, Eastern Hog-nosed Snake, Northern Rough Greensnake (Opheodrys a. aestivus), and Eastern Smooth Earthsnake (Virginia v. valeriae). Northern Leopard Frogs have an S2 status, meaning that there have been only 6-20 documented occurrences, or few remaining individuals within the state. Species with this status are described as "very rare and imperiled" and some factor renders it susceptible to extinction. The other 7 species had S3 status, indicating that 21-100 occurrences have been documented; these species are potentially vulnerable to extirpation. All 8 of these species are common globally.

Using drift fence arrays and incidental sightings, 32 Northern Leopard Frogs were observed: 4 in reclaimed grasslands, 9 in reclaimed shrub-pole habitat, 14 in fragmented forests, 3 in intact forests, and 2 in off-mine shrub-pole habitat. We captured 2 Northern Red Salamanders in fragmented forests and 3 in intact forests. We trapped 3 Little Brown Skinks: 1 in a reclaimed grassland, 1 in an intact forest, and 1 in an off-mine grassland. All 4 Eastern Wormsnakes that we captured were in intact forests. Of the 8 Timber Rattlesnakes observed over the 3 years of study, 4 were seen in reclaimed shrub-pole habitat, 1 on the edge between reclaimed shrub-pole and fragmented forest habitats, 1 in a fragmented forest, and 1 in an intact forest. Two of 6 Eastern Hog-nosed Snakes that we captured or sighted were in reclaimed grasslands; the rest were in reclaimed shrub-pole habitat. We sighted 2 Northern Rough Greensnakes -1 in an intact forest along a road and 1 in reclaimed shrub-pole habitat. One Eastern Smooth Earthsnake was captured in an intact forest. 
Appendix 1. Herpetofaunal species that may potentially occur (Exp=Expected; $x)$ in reclaimed grassland, reclaimed shrub-pole, fragmente d forest, and intact forest treatments (Behler and King 1995; Green and Pauley 1987; Conant and Collins 1998), compared to those actually observed (Obs) in drift fence arrays (a; 2000-2002), from incidental sightings $(i ; 2000-2002)$, during stream surveys $(s ; 2001-2002)$ and under coverboards (c; 2001-2002) in southern West Virginia in a reclaimed mountaintop removal mine landscape. Ranges of species were based on Green and Pauley (1987) and personal communication with T. Pauley.*

\begin{tabular}{|c|c|c|c|c|c|c|c|c|}
\hline \multirow[b]{2}{*}{ Species } & \multicolumn{2}{|c|}{ Grassland } & \multicolumn{2}{|c|}{ Shrub-pole } & \multicolumn{2}{|c|}{$\begin{array}{l}\text { Fragmented } \\
\text { Forest } \\
\end{array}$} & \multicolumn{2}{|c|}{ Intact Forest } \\
\hline & $\operatorname{Exp}$ & Obs & $\operatorname{Exp}$ & Obs & Exp & Obs & Exp & Obs \\
\hline \multicolumn{9}{|l|}{ Salamanders (Order Caudata) } \\
\hline \multicolumn{9}{|l|}{ Family Cryptobranchidae } \\
\hline $\begin{array}{l}\text { Eastern Hellbender (Cryptobranchus a. alleganiensis) } \\
\text { (Entirely aquatic; rivers and permanent, higher-order } \\
\text { streams) }\end{array}$ & & & & & $\mathrm{x}$ & & $\mathrm{x}$ & \\
\hline \multicolumn{9}{|l|}{ F. Proteidae } \\
\hline $\begin{array}{l}\text { Common Mudpuppy (Necturus m. maculosus) } \\
\text { (Entirely aquatic; require permanent water bodies) }\end{array}$ & & & & & $\mathrm{x}$ & & $\mathrm{x}$ & \\
\hline \multicolumn{9}{|l|}{ F. Ambystomatidae } \\
\hline $\begin{array}{l}\text { Jefferson Salamander (Ambystoma jeffersonianum) } \\
\text { (Vernal pools must be near) }\end{array}$ & & & & & $\mathrm{x}$ & & $\mathrm{x}$ & \\
\hline $\begin{array}{l}\text { Spotted Salamander (A. maculatum) } \\
\text { (Vernal pools must be near) }\end{array}$ & & $\mathrm{a}, \mathrm{i}$ & & $\mathrm{a}, \mathrm{c}$ & $\mathrm{x}$ & a & $\mathrm{x}$ & a \\
\hline $\begin{array}{l}\text { Marbled Salamander (A. opacum) } \\
\text { (Vernal pools must be near) }\end{array}$ & & & & & $\mathrm{x}$ & & $\mathrm{x}$ & \\
\hline \multicolumn{9}{|l|}{ F. Salamandridae } \\
\hline $\begin{array}{l}\text { Red-spotted Newt (Notophthalmus v. viridescens) } \\
\text { (Adults of this spp. need permanent or semi - } \\
\text { permanent water) }\end{array}$ & & $\mathrm{a}, \mathrm{i}$ & & $\mathrm{a}, \mathrm{i}$ & $\mathrm{x}$ & $\mathrm{a}, \mathrm{i}, \mathrm{s}$ & $\mathrm{x}$ & $\mathrm{a}, \mathrm{i}$ \\
\hline $\begin{array}{l}\text { Red Eft (Notophthalmus v. viridescens) } \\
\text { (Juveniles of this spp. are terrestrial) }\end{array}$ & & $\mathrm{c}$ & & $\mathrm{c}$ & & $\mathrm{s}, \mathrm{c}$ & & $\mathrm{s}, \mathrm{c}$ \\
\hline \multicolumn{9}{|l|}{ F. Plethodontidae } \\
\hline $\begin{array}{l}\text { Green Salamander (Aneides aeneus) } \\
\text { (Rock faces with crevices) }\end{array}$ & & & & & $\mathrm{x}$ & & $\mathrm{x}$ & \\
\hline $\begin{array}{l}\text { Northern Dusky Salamander (Desmognathus fuscus) } \\
\text { (Streams, springs, brooks, etc.) }\end{array}$ & & & & & $\mathrm{x}$ & $\mathrm{a}, \mathrm{i}, \mathrm{s}$ & $\mathrm{x}$ & $\mathrm{i}, \mathrm{s}$ \\
\hline $\begin{array}{l}\text { Seal Salamander (D. monticola) } \\
\text { (In streams) }\end{array}$ & & & & & $\mathrm{x}$ & $\mathrm{a}, \mathrm{i}, \mathrm{s}$ & $\mathrm{x}$ & $\mathrm{a}, \mathrm{i}, \mathrm{s}$ \\
\hline $\begin{array}{l}\text { Spring Salamander (Gyrinophilus porphyriticus) } \\
\text { (Springs, streams, seepages) }\end{array}$ & & & & & $\mathrm{x}$ & $\mathrm{a}, \mathrm{s}$ & $\mathrm{x}$ & $\mathrm{i}, \mathrm{s}$ \\
\hline $\begin{array}{l}\text { Four-toed Salamander (Hemidactylium scutatum) } \\
\text { (Forests, especially near fens; breed in } \\
\text { sphagnum bogs) }\end{array}$ & & $\mathrm{a}$ & & & $\mathrm{x}$ & $\mathrm{a}$ & $\mathrm{x}$ & \\
\hline
\end{tabular}


Appendix 1. Cont'd.

\begin{tabular}{|c|c|c|c|c|c|c|c|c|}
\hline \multirow[b]{2}{*}{ Species } & \multicolumn{2}{|c|}{ Grassland } & \multicolumn{2}{|c|}{ Shrub-pole } & \multicolumn{2}{|c|}{$\begin{array}{l}\text { Fragmented } \\
\text { Forest }\end{array}$} & \multicolumn{2}{|c|}{ Intact Forest } \\
\hline & $\operatorname{Exp}$ & Obs & $\operatorname{Exp}$ & Obs & $\operatorname{Exp}$ & $O b s$ & $\operatorname{Exp}$ & Obs \\
\hline $\begin{array}{l}\text { Southern Two-lined Salamander } \\
\text { (Eurycea cirrigera) } \\
\text { (Streams, seepages, but will go far from } \\
\text { streamsides into wooded areas) }\end{array}$ & & $\mathrm{c}$ & & & $\mathrm{X}$ & $\mathrm{a}, \mathrm{i}, \mathrm{s}, \mathrm{c}$ & $\mathrm{x}$ & $\mathrm{i}, \mathrm{s}$ \\
\hline $\begin{array}{l}\text { Long-tailed Salamander } \\
\text { (E. l. longicauda) } \\
\text { (In or near streams, springs, or seepages) }\end{array}$ & & & & & $\mathrm{x}$ & $\mathrm{i}, \mathrm{s}$ & $\mathrm{X}$ & \\
\hline $\begin{array}{l}\text { Eastern Red-backed Salamander } \\
\text { (Plethodon cinereus) }\end{array}$ & & $\mathrm{i}$ & & $\mathrm{c}$ & $\mathrm{x}$ & $\mathrm{a}, \mathrm{i}, \mathrm{s}, \mathrm{c}$ & $\mathrm{X}$ & $\mathrm{a}, \mathrm{i}, \mathrm{s}, \mathrm{c}$ \\
\hline $\begin{array}{l}\text { Northern Slimy Salamander } \\
\text { (P. glutinosus) }\end{array}$ & & & & $\mathrm{a}$ & $\mathrm{x}$ & $\mathrm{a}, \mathrm{i}, \mathrm{c}$ & $\mathrm{x}$ & $\mathrm{a}, \mathrm{i}$ \\
\hline $\begin{array}{l}\text { Cumberland Plateau Salamander } \\
\text { (P. kentucki) }\end{array}$ & & & & & $\mathrm{x}$ & $\mathrm{a}, \mathrm{c}$ & $\mathrm{X}$ & $\mathrm{a}, \mathrm{i}, \mathrm{s}$ \\
\hline $\begin{array}{l}\text { Southern Ravine Salamander } \\
(P . \text { richmondi) }\end{array}$ & & & & & $\mathrm{x}$ & $\mathrm{i}, \mathrm{c}$ & $\mathrm{x}$ & $\mathrm{c}$ \\
\hline $\begin{array}{l}\text { Wehrle's Salamander } \\
(P . \text { wehrlei })\end{array}$ & & & & & $\mathrm{x}$ & & $\mathrm{x}$ & \\
\hline $\begin{array}{l}\text { Midland Mud Salamander } \\
\text { (Muddy springs, seepages, brooks, swampy } \\
\text { areas) }\end{array}$ & & & & & $\mathrm{x}$ & & $\mathrm{x}$ & \\
\hline (Pseudotriton montanus diastictus) & & & & & & & & \\
\hline $\begin{array}{l}\text { Northern Red Salamander } \\
(P . r . \text { ruber }) \\
\text { (Springs, seeps, brooks) }\end{array}$ & $\mathrm{x}$ & & $\mathrm{x}$ & & $\mathrm{x}$ & $\mathrm{s}$ & $\mathrm{x}$ & $\mathrm{a}, \mathrm{s}$ \\
\hline $\begin{array}{l}\text { Toads and Frogs (O. Anura) } \\
\text { F. Pelobatidae }\end{array}$ & & & & & & & & \\
\hline $\begin{array}{l}\text { Eastern Spadefoot } \\
\text { (Scaphiopus holbrookii) } \\
\text { (Primary habitat feature selected for is sandy, } \\
\text { gravelly soil) }\end{array}$ & $\mathrm{x}$ & & $\mathrm{x}$ & & $\mathrm{x}$ & & $\mathrm{x}$ & \\
\hline F. Bufonidae & & & & & & & & \\
\hline $\begin{array}{l}\text { Eastern American Toad } \\
\text { (Bufo a. americanus) } \\
\text { (Breed in pools, swamps, etc.; spend summer } \\
\text { in upland habitat in pastures and woods) }\end{array}$ & $\mathrm{x}$ & $\mathrm{a}, \mathrm{i}$ & $\mathrm{x}$ & $\mathrm{a}, \mathrm{i}$ & $\mathrm{x}$ & $\mathrm{a}, \mathrm{i}$ & $\mathrm{x}$ & $\mathrm{a}, \mathrm{i}$ \\
\hline $\begin{array}{l}\text { Fowler's Toad } \\
\text { (B. fowleri) } \\
\text { (Breed in streams, lakes; use wide variety of } \\
\text { terrestrial habitats) }\end{array}$ & & $\mathrm{a}$ & $\mathrm{x}$ & & $\mathrm{x}$ & $\mathrm{i}, \mathrm{s}$ & $\mathrm{x}$ & $\mathrm{i}$ \\
\hline
\end{tabular}


Appendix 1. Cont'd.

\begin{tabular}{|c|c|c|c|c|c|c|c|c|}
\hline \multirow[b]{2}{*}{ Species } & \multicolumn{2}{|c|}{ Grassland } & \multicolumn{2}{|c|}{ Shrub-pole } & \multicolumn{2}{|c|}{$\begin{array}{l}\text { Fragmented } \\
\text { Forest }\end{array}$} & \multicolumn{2}{|c|}{$\begin{array}{l}\text { Intact } \\
\text { Forest }\end{array}$} \\
\hline & $\operatorname{Exp}$ & $O b s$ & Exp & $O b s$ & $\operatorname{Exp}$ & $O b s$ & $\operatorname{Exp}$ & $O b s$ \\
\hline F. Hylidae & & & & & & & & \\
\hline $\begin{array}{l}\text { Cope's Gray Treefrog } \\
\text { (Hyla chrysoscelis) } \\
\text { (Most often in trees and shrubs, but will breed } \\
\text { in flooded grasslands) }\end{array}$ & $\mathrm{x}$ & & $\mathrm{x}$ & $\mathrm{a}, \mathrm{i}$ & $\mathrm{x}$ & $\mathrm{i}$ & $\mathrm{x}$ & $\mathrm{i}$ \\
\hline $\begin{array}{l}\text { Northern Spring Peeper } \\
\text { (Pseudacris } \text { c. crucifer) } \\
\text { (Near water) }\end{array}$ & & $\mathrm{i}$ & $\mathrm{x}$ & $\mathrm{a}, \mathrm{i}$ & $\mathrm{x}$ & $\mathrm{a}, \mathrm{i}$ & $\mathrm{x}$ & $\mathrm{a}, \mathrm{i}$ \\
\hline $\begin{array}{l}\text { Mountain Chorus Frog } \\
\text { (P. brachyphona) } \\
\text { (Woodlands) }\end{array}$ & & & & $\mathrm{i}$ & $\mathrm{x}$ & & $\mathrm{x}$ & $\mathrm{i}$ \\
\hline F. Ranidae & & & & & & & & \\
\hline $\begin{array}{l}\text { American Bullfrog } \\
\text { (Rana catesbeiana) } \\
\text { (Primary habitat feature selected for is } \\
\text { permanent water) }\end{array}$ & $\mathrm{x}$ & $\mathrm{a}, \mathrm{i}$ & $\mathrm{x}$ & $\mathrm{a}, \mathrm{i}$ & $\mathrm{x}$ & $\mathrm{a}, \mathrm{i}, \mathrm{s}$ & $\mathrm{x}$ & $\mathrm{a}, \mathrm{i}, \mathrm{s}$ \\
\hline $\begin{array}{l}\text { Northern Green Frog } \\
\text { (R. clamitans melanota) } \\
\text { (Requires permanent water sources) }\end{array}$ & $\mathrm{x}$ & $\mathrm{a}, \mathrm{i}$ & $\mathrm{x}$ & $\mathrm{a}, \mathrm{i}$ & $\mathrm{x}$ & $\mathrm{a}, \mathrm{i}, \mathrm{s}$ & $\mathrm{x}$ & $\mathrm{a}, \mathrm{i}, \mathrm{s}$ \\
\hline $\begin{array}{l}\text { Pickerel Frog } \\
\text { (R. palustris) }\end{array}$ & $\mathrm{x}$ & $\mathrm{a}$ & $\mathrm{x}$ & $\mathrm{a}, \mathrm{i}$ & $\mathrm{x}$ & $\mathrm{a}, \mathrm{i}, \mathrm{s}$ & $\mathrm{x}$ & $\mathrm{a}, \mathrm{i}, \mathrm{s}$ \\
\hline $\begin{array}{l}\text { Northern Leopard Frog } \\
\text { (R. pipiens) } \\
\text { (Use wide variety of aquatic habitats; in } \\
\text { summer, will use meadows and forests) }\end{array}$ & $\mathrm{x}$ & $\mathrm{a}$ & $\mathrm{x}$ & $\mathrm{a}, \mathrm{i}$ & $\mathrm{x}$ & $\mathrm{a}, \mathrm{i}$ & $\mathrm{x}$ & $\mathrm{a}, \mathrm{i}$ \\
\hline $\begin{array}{l}\text { Wood Frog } \\
(\text { R. sylvatica })\end{array}$ & & & & & $\mathrm{x}$ & $\mathrm{a}$ & $\mathrm{x}$ & $\mathrm{a}, \mathrm{I}$ \\
\hline $\begin{array}{l}\text { Lizards (O. Squamata, Suborder Lacertilia) } \\
\text { F. Scincidae }\end{array}$ & & & & & & & & \\
\hline $\begin{array}{l}\text { Broad-headed Skink } \\
\text { (Eumeces laticeps) } \\
\text { (Will use open areas provided there is low } \\
\text { shelter and debris) }\end{array}$ & $\mathrm{x}$ & & $\mathrm{x}$ & & $\mathrm{x}$ & & $\mathrm{x}$ & \\
\hline $\begin{array}{l}\text { Coal Skink } \\
\text { (E. anthracinus) } \\
\text { (Damp woodlands with abundant leaf litter and } \\
\text { loose stones) }\end{array}$ & & & & & $\mathrm{x}$ & & $\mathrm{x}$ & \\
\hline
\end{tabular}


Appendix 1. Cont'd.

\begin{tabular}{|c|c|c|c|c|c|c|c|c|}
\hline \multirow[b]{2}{*}{ Species } & \multicolumn{2}{|c|}{ Grassland } & \multicolumn{2}{|c|}{ Shrub-pole } & \multicolumn{2}{|c|}{$\begin{array}{l}\text { Fragmented } \\
\text { Forest }\end{array}$} & \multicolumn{2}{|c|}{$\begin{array}{l}\text { Intact } \\
\text { Forest }\end{array}$} \\
\hline & $\operatorname{Exp}$ & $O b s$ & $\operatorname{Exp}$ & $O b s$ & $\operatorname{Exp}$ & $O b s$ & $\operatorname{Exp}$ & $O b s$ \\
\hline $\begin{array}{l}\text { Common Five-lined Skink } \\
\text { (E.fasciatus) } \\
\text { (Will use open areas with ample debris and } \\
\text { cover objects) }\end{array}$ & $\mathrm{x}$ & & $\mathrm{x}$ & $\mathrm{a}$ & $\mathrm{x}$ & $\mathrm{a}$ & $\mathrm{x}$ & $\mathrm{a}$ \\
\hline $\begin{array}{l}\text { Little Brown Skink } \\
\text { (Scincella lateralis) } \\
\text { (Dry, open woodlands) }\end{array}$ & & $\mathrm{a}$ & $\mathrm{x}$ & & $\mathrm{x}$ & & $\mathrm{x}$ & $\mathrm{a}$ \\
\hline $\begin{array}{l}\text { F. Phrynosomatidae } \\
\text { Eastern Fence Lizard } \\
\text { (Sceloporus undulatus) } \\
\text { (Dry and / or sunny areas) }\end{array}$ & $\mathrm{x}$ & $\mathrm{a}, \mathrm{i}$ & $\mathrm{x}$ & $\mathrm{a}, \mathrm{i}$ & $\mathrm{x}$ & $\mathrm{i}$ & $\mathrm{x}$ & $\mathrm{i}$ \\
\hline $\begin{array}{l}\text { Snakes (O. Squamata, S.O. Serpentes) } \\
\text { F. Colubridae }\end{array}$ & & & & & & & & \\
\hline $\begin{array}{l}\text { Eastern Ratsnake } \\
\text { (Elaphe alleghaniensis) }\end{array}$ & $\mathrm{x}$ & $\mathrm{a}, \mathrm{i}, \mathrm{s}$ & $\mathrm{x}$ & $\mathrm{a}, \mathrm{i}$ & $\mathrm{x}$ & $\mathrm{a}, \mathrm{i}$ & $\mathrm{x}$ & $\mathrm{a}, \mathrm{i}$ \\
\hline $\begin{array}{l}\text { Common Watersnake } \\
\text { (Nerodia s. sipedon) } \\
\text { (Aquatic habitat must be present) }\end{array}$ & $\mathrm{x}$ & $\mathrm{a}$ & $\mathrm{x}$ & $\mathrm{a}$ & $\mathrm{x}$ & $\mathrm{i}, \mathrm{s}$ & $\mathrm{x}$ & $\mathrm{s}$ \\
\hline $\begin{array}{l}\text { Eastern Black Kingsnake } \\
\text { (Lampropeltis getulus niger) }\end{array}$ & $\mathrm{x}$ & & $\mathrm{x}$ & & $\mathrm{x}$ & & $\mathrm{x}$ & \\
\hline $\begin{array}{l}\text { Eastern Milksnake } \\
\text { (L.t.triangulum) }\end{array}$ & $\mathrm{x}$ & $\mathrm{a}$ & $\mathrm{x}$ & $\mathrm{a}$ & $\mathrm{x}$ & $\mathrm{a}$ & $\mathrm{x}$ & $\mathrm{a}, \mathrm{i}$ \\
\hline $\begin{array}{l}\text { Eastern Gartersnake } \\
\text { (Thamnophis s. sirtalis) }\end{array}$ & $\mathrm{x}$ & $\mathrm{a}$ & $\mathrm{x}$ & $\mathrm{a}$ & $\mathrm{x}$ & $\mathrm{a}, \mathrm{i}$ & $\mathrm{x}$ & $\mathrm{a}, \mathrm{i}$ \\
\hline $\begin{array}{l}\text { Common Ribbonsnake } \\
\text { (T. s. sauritus) } \\
\text { (Near water) }\end{array}$ & $\mathrm{x}$ & & $\mathrm{x}$ & & & & & \\
\hline $\begin{array}{l}\text { Eastern Hog-nosed Snake } \\
\text { (Heterodon platirhinos) } \\
\text { (Sandy or loose soils) }\end{array}$ & $\mathrm{x}$ & $\mathrm{a}, \mathrm{i}$ & $\mathrm{x}$ & $\mathrm{a}$ & $\mathrm{x}$ & & $\mathrm{x}$ & \\
\hline $\begin{array}{l}\text { Eastern Smooth Earthsnake } \\
\text { (Virginia v. valeriae) }\end{array}$ & $\mathrm{x}$ & & $\mathrm{x}$ & & $\mathrm{x}$ & & $\mathrm{x}$ & $\mathrm{i}$ \\
\hline $\begin{array}{l}\text { Eastern Wormsnake } \\
\text { (Carphophis a. amoenus) } \\
\text { (Forests; moist, rocky soils) }\end{array}$ & $\mathrm{x}$ & & $\mathrm{x}$ & & $\mathrm{x}$ & & $\mathrm{x}$ & $\mathrm{a}$ \\
\hline $\begin{array}{l}\text { Northern Black Racer } \\
\text { (Coluber c. constrictor) }\end{array}$ & $\mathrm{x}$ & $\mathrm{a}, \mathrm{i}$ & $\mathrm{x}$ & $\mathrm{a}$ & $\mathrm{x}$ & $\mathrm{i}$ & $\mathrm{x}$ & $\mathrm{i}$ \\
\hline $\begin{array}{l}\text { Northern Brownsnake } \\
\text { (Storeria } \text { d. dekayi) } \\
\text { (Wooded habitat; hillsides; swampy areas) }\end{array}$ & $\mathrm{x}$ & & $\mathrm{x}$ & & $\mathrm{x}$ & & $\mathrm{x}$ & \\
\hline $\begin{array}{l}\text { Northern Red-bellied Snake } \\
(\text { S. o. occipitomaculata })\end{array}$ & & & & & $\mathrm{x}$ & $\mathrm{a}$ & $\mathrm{x}$ & $\mathrm{a}, \mathrm{i}$ \\
\hline
\end{tabular}


Appendix 1. Cont'd.

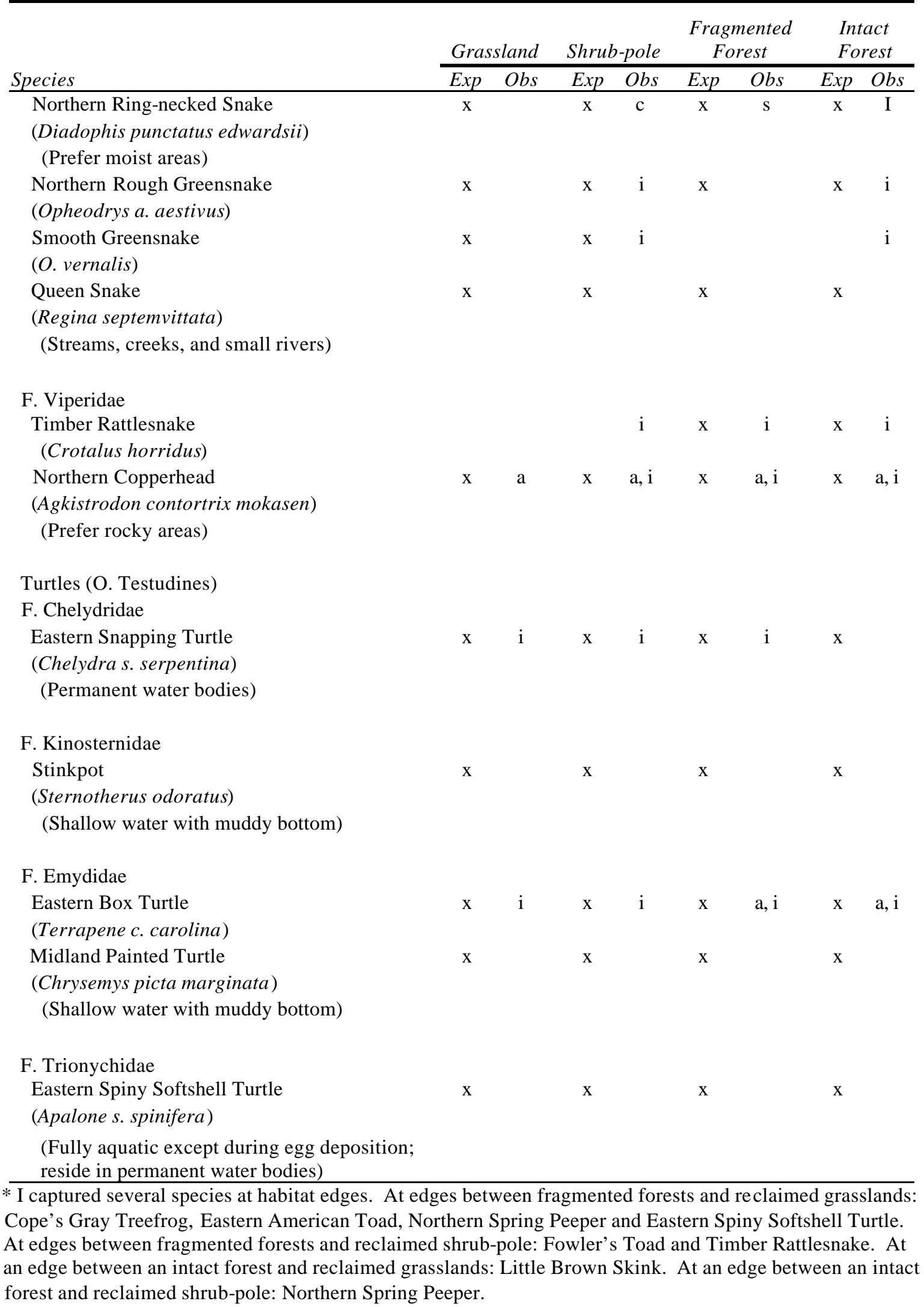




\section{LITERATURE CITED}

ABRAMSON, R. 2001. Mountaintop Removal: Necessity or Nightmare? Now \& Then, Winter:2024.

ADAMS, J. P., M. J. LACKI, AND M. D. BAKER. 1996. Response of herpetofauna to silvicultural prescriptions in the Daniel Boone National Forest, Kentucky. Proceedings of the Annual Conference of the Southeastern Association of Fish and Wildlife Agencies 50:312-320.

ALBERS, P. H., AND R. M. PROUTY. 1987. Survival of spotted salamander eggs in temporary woodland ponds of coastal Maryland. Environmental Pollution 46:45-61.

AMMER, F. K. 2003. Population level dynamics of grasshopper sparrow populations breeding on reclaimed mountaintop mines in West Virginia. Ph.D. Dissertation, West Virginia University, Morgantown.

ANONYMOUS. 1980. New technique advances valley fill technology. Green Lands 10:34-35, 38.

ANONYMOUS. 2002. Burying valleys, poisoning streams. Editorial/Op-ed. The New York Times, Co., May 4, 2002. 1 pp.

ASH, A. N. 1988. Disappearance of salamanders for clearcut plots. The Journal of the Elisha Mitchell Scientific Society. 104:116-122.

----. 1997. Disappearance and return of plethodontid salamanders to clearcut plots in the southern Blue Ridge Mountains. Conservation Biology 11:983-989.

ASKINS, R. A., J. F. LYNCH, AND R. GREENBERG. 1990. Population declines in migratory birds in eastern North America. Current Ornithology 7:1-57.

BALCERZAK, M. J., AND P. B. WOOD. 2003. Red-shouldered hawk (Buteo lineatus) abundance and habitat in a reclaimed mine landscape. Journal of Raptor Research 37: 188197.

BARNHISEL, R. I., R. G. DARMODY, AND W. L. DANIELS (eds.). 2000. Reclamation of Drastically Disturbed Lands. American Society of Agronomy, Inc., Madison. 1082 pp.

BEATTIE, R. C. and R. TYLER-JONES. 1992. The effects of low $\mathrm{pH}$ and aluminum on breeding success in the frog Rana temporaria. Journal of Herpetology 26:353-360.

BEEBEE, T. J. C., R. J. FlOWER, A. C. STEVEnSON, S. T. PATRICK, P. G. APPLEBY, C. FLETCHER, C. MARSH, J. NATKANSKI, B. RIPPEY, AND R. W. BATTARBEE. 1990. Decline of the Natterjack Toad Bufo calamita in Britain: palaeoecological, documentary and experimental evidence for breeding site acidification. Biological Conservation 53:1-20. 
BEERS, T. W., P. E. DRESS, AND L. C. WENSEL. 1966. Aspect transformation in site productivity research. Journal of Forestry 64:691-692.

BEHLER, J. L., AND F. W. KING. 1995. National Audobon Society field guide to North American reptiles and amphibians. Alfred A. Knopf, New York, New York.

BELL, J. C., W. L. DANIELS, AND C. E. ZIPPER. 1989. The practice of "approximate original contour" in the Central Appalachians. I. Slope stability and erosion potential. Landscape and Urban Planning 18:127-128.

BISHOP, S. C. 1967. Handbook of Salamanders. Comstock Publishing, Ithaca. 555 pp.

BLAUSTEIN, A.R., AND D.B. WAKE. 1990. Declining amphibian populations: a global phenomenon? Trends in Ecology and Evolution 5:203-204.

BLAUSTEIN, A.R., D.B. WAKE, AND W.P. SOUSA. 1994. Amphibian declines: judging stability, persistence, and susceptibility of populations to local and global extinctions. Conservation Biology 8:60-71.

BLYMER, M. J., AND B. S. MCGINNES. 1977. Observations on possible detrimental effects of clearcutting on terrestrial amphibians. Bulletin of the Maryland Herpetological Society. 13(2):79-83.

BRADFORD, D. F. 1991. Mass mortality and extinction in a high-elevation population of Rana muscosa. Journal of Herpetology 25:174-177.

BRENNER, F. J. 1985. Land reclamation after strip coal mining in the United States. Mining Magazine. September, p. 211-217.

-----. 2000. Wildlife and fishery considerations. In R. I. Barnhisel, R. G. Darmody, and W. L. Daniels (eds.). Reclamation of Drastically Disturbed Lands, pp. 399-413. American Society of Agronomy, Inc., Madison. 1082 pp.

BRENNER, F. J., E. K. BRENNER, AND P. E. BRENNER. 1992. Analysis of drift fence arrays as a census method for vertebrate communities on a proposed mine site. Journal of the Pennsylvania Academy of Science 65:117-122.

BRENNER, F. J., AND C. GOUGHLER. 1983. Role of nurse crops in encouraging establishment of natives on reclaimed lands: An evaluation (Pennsylvania). Restoration Management Notes. 1:31-32.

BRUCE, R. C. 1978. Life history patterns of the salamander Gyrinophilus porphyriticus in the Cowee Mountains, North Carolina. Herpetologica 34:325-332.

BRYANT, G., S. MCPHILLIAMY, AND H. CHILDERS. 2002. A survey of the water quality of streams in the primary region of mountaintop / valley fill coal mining: October 1999 to January 2001. United States Environmental Protection Agency, Region III and Signal Corporation, Wheeling. 
BURGER, J. W. 1935. Plethodon cinereus (Green) in eastern Pennsylvania and New Jersey. The American Naturalist 64:578-586.

BURTON, T. M., AND G. E. LIKENS. 1975. Salamander populations and biomass in the Hubbard Brook Experimental Forest, New Hampshire. Copeia 541-546.

BURY, R. B. 1983. Differences in amphibian populations in logged and old growth redwood forest. Northwest Science. 57:167-178.

BURY, R. B., AND P. S. CORN. 1987. Evaluation of pitfall trapping in northwestern forests: trap arrays with drift fences. Journal of Wildlife Management 51:112-119.

CAMPBELL, H. W., AND S. P. CHRISTMAN. 1982. Field techniques for herpetofaunal community analysis. Pages 193-200 in N. J. Scott, editor. Herpetological communities. U. S. Fish and Wildlife Service Resource Report Number 13.

CARPENTER, S. G. 1992. Soil survey of Nicholas County, West Virginia. United States Department of Agriculture, Soil Conservation Service. United States Government Printing Office, Washington, D.C. 138 pp.

CAUGHLEY, G., AND A. GUNN. 1995. Conservation biology in theory and practice. Blackwell Science, Cambridge, MA.

CHAMBERS, R. J., AND S. DROEGE. 2002. Leaf litter bags as an index to populations of northern two-lined salamanders (Eurycea bislineata). Wildlife Society Bulletin 30:71-74.

CHAMBLIN, H. D. 2002. Small mammal communities on a reclaimed mountaintop mine valley fill landscape in southern West Virginia. M. S. Thesis. West Virginia University, Morgantown, West Virginia.

CLARK, K. L. 1986. Distributions of anuran populations in central Ontario relative to habitat acidity. Water, Air, and Soil Pollution 30:727-734.

CLAWSON, R. G., B. G. LOCKABY, AND R. H. JONES. 1997. Amphibian responses to helicopter harvesting in forested floodplains of low order, blackwater streams. Forest Ecology and Management 90:225-235.

CODY, R. P., AND J. K. SMITH. 1997. Applied Statistics and the SAS Programming Language. 4th ed. Prentice Hall, Upper Saddle River.

CONANT, R., AND J. T. COLLINS. 1998. Reptiles and amphibians: eastern/central North America. $3^{\text {rd }}$ edition. Houghton Mifflin Company, Boston, Massachusetts.

CONGDON, J. D., A. E. DUNHAM, AND R. C. VAN LOBEN SELS. 1993. Delayed sexual maturity and demographics of Blanding's turtles (Emydoidea blandingii): implications for conservation and management of long-lived organisms. Conservation Biology 7:826-833. 
-----. 1994. Demographics of common snapping turtles (Chelydra serpentina): implications for conservation and management of long-lived organisms. American Zoologist 34:397-408.

CORN, S. P. 1994. Straight line drift fences and pitfall traps. Pages 109-117 in W. K. Heyer, M. A. Donnelly, R. W. McDarmid, L. C. Hayek, and M. S. Foster, editors. Measuring and monitoring biological diversity: standard methods for amphibians. Smithsonian Institute Press, Washington D. C.

CORN, P. S., AND R. B. BURY. 1989. Logging in western Oregon: responses of headwater habitats and stream amphibians. Forest Ecology and Management 29:39-57.

CRUMP, M. L. AND N. J. SCOTT, JR. 1994. Visual encounter surveys. In W. K. Heyer, M. A. Donnelly, R. W. McDarmid, L. C. Hayek, and M. S. Foster (eds.), Measuring and Monitoring Biological Diversity: Standard Methods for Amphibians, pp. 84-92. Smithsonian Institute Press, Washington D. C.

CULOTTA, E. 1995. Ecologists flock to snowbird for varied banquet of findings. Science 269:1045-1046.

DALE, J. M., B. FREEDMAN, AND J. KEREKES. 1985. Acidity and associated water chemistry of amphibian habitats in Nova Scotia. Canadian Journal of Zoology 63:97-105.

DANIELS, W. L., AND D. F. AMOS. 1981. Mapping, characterization and genesis of mine soils on a reclamation research area in Wise County, Virginia. P. 261-265 In Proceedings from the Symposium on Surface Mining, Hydrology, Sedimentology, and Reclamation, Lexington, KY, 7-11 December. Office of Engineering Services, College of Engineering, University of Kentucky, Lexington, KY.

DANIELS, W. L., AND B. R. STEWART. 2000. Reclamation of Appalachian coal refuse disposal areas. In R. I. Barnhisel, R. G. Darmody, and W. L. Daniels (eds.). Reclamation of Drastically Disturbed Lands, pp. 433-459. American Society of Agronomy, Inc., Madison. $1082 \mathrm{pp}$.

DAOUST, J. L. 1991. Coping with dehydration of trapped terrestrial anurans. Herpetological Review 22:95.

DAVIC, R. D., AND L. P. ORR. 1987. The relationship between rock density and salamander density in a mountain stream. Herpetologica 43:357-361.

DEGRAAF, R. M. 1992. Effects of even-aged management on forest birds at northern hardwood stand interfaces. Forest Ecology and Management 46:95-110.

DEGRAAF, R. M. AND M. YAMASAKI. 1992. A nondestructive technique to monitor the relative abundance of terrestrial salamanders. Wildlife Society Bulletin 20:260-264. 
DEMAYNADIER, P. G., AND M. L. HUNTER, JR. 1995. The relationship between forest management and amphibian ecology: a review of the North American literature.

Environmental Review 3:230-261.

-----. 1998. Effects of silvicultural edges on the distribution and abundance of amphibians in Maine. Conservation Biology. 12:340-352.

DROEGE, S., L. MONTI, AND D. LANTZ. 1997. The terrestrial monitoring program: rationale, protocol, call for participation, and methodological experiments. http://www.mp1pwrc.usgs.gov/sally/amphibs.html

DODD, JR. C. K. 1991. The status of the red hills salamander Phaeognathus hubrichti, Alabama, USA, 1976-1988. Biological Conservation. 55:57-75.

-----. 2001. North American Box Turtles: A Natural History. University of Oklahoma Press, Norman, Oklahoma.

DUGUAY, J. P., AND P. B. WOOD. 2002. Salamander abundance in regenerating forest stands on the Monongahela National Forest, West Virginia. Forest Science 48:331-335.

DUGUAY, J. P., P. B. WOOD, AND G. W. MILLER. 2000. Effects of timber harvest on invertebrate biomass and avian nest success. Wildlife Society Bulletin 28:1-9.

DUNSON, W. A. and J. CONNELL. 1982. Specific inhibition of hatching in amphibian embryos by low pH. Journal of Herpetology 16:314-316.

DUPUIS, L. A., J. N. M. SMITH, AND F. BUNNELL. 1995. Relation of terrestrial-breeding amphibian abundance to tree-stand age. Conservation Biology. 9:645-652.

ENGE, K. M. 1997. Use of silt fencing and funnel traps for drift fences. Herpetological Review 28:30-31.

ENGE, K. M., AND W. R. MARION. 1986. Effects of clearcutting and site preparation on herpetofauna of a north Florida flatwoods. Forest Ecology and Management. 14:177-192.

FEDER, M. E. 1983. Integrating the ecology and physiology of plethodontid salamanders. Herpetologica 39:291-310.

FEDERAL INTERAGENCY STREAM RESTORATION WORKING GROUP. 1998. Stream Corridor Restoration: Principles, Processes, and Practices. GPO Item No. 0120-A; SuDocs No. A 57.6/2:EN 3/PT.653.

FEDORKO, N., AND M. BLAKE. 1998. A geologic overview of mountaintop removal mining in West Virginia. Executive summary of a report to the Committee on Post-Mining Land Use and Economic Aspects of Mountaintop Removal Mining, October 26, 1998. 16 pp.

FELLERS, G.M., AND C.A. DROST. 1994. Sampling with artificial cover. Pages 146-150 in W. R. Heyer, M. A. Donnely, R. W. McDarmid, L. C. Hayek, and M. S. Foster, editors. 
Measuring and monitoring biological diversity: standard methods for amphibians. Smithsonian Institute Press, Washington D. C., USA.

FELLERS G. M., C. A. DROST, AND W. R. HEYER. 1994. Handling live amphibians. Pages 275-276 in W. R. Heyer, M. A. Donnely, R. W. McDarmid, L. C. Hayek, and M. S. Foster, editors. Measuring and monitoring biological diversity: standard methods for amphibians. Smithsonian Institute Press, Washington D. C., USA

FOWLER D. F., D. M. HILL, AND L. J. FOWLER. 1985. Colonization of coal surface mine sediment ponds in southern Appalachia by aquatic organisms and breeding amphibians. In Brooks R. P., J. B. Hill, F. J. Brenner, and S. Carpets (eds.), Wetlands and Water Management on Mined Lands: Proceedings of a Conference, pp. 261-280. The Pennsylvania State University, State College.

FRASER, D. F. 1974. Interactions between salamanders of the genus Plethodon in the central Appalachians: studies on coexistence and competition. Ph.D. Dissertation, University of Maryland, College Park.

FREDA, J. 1986. The influence of acidic pond water on amphibians: a review. Water, Air, and Soil Pollution 30:439-450.

FREDA, J., AND W. A. DUNSON. 1984. Sodium balance of amphibian larvae exposed to low environmental pH. Physiological Zoology 57:435-443.

----. 1985a. Field and laboratory studies of ion balance and growth rates of ranid tadpoles chronically exposed to low pH. Copeia 1985:415-423.

-----. 1985b. The influence of external cation concentration on the hatching of amphibian embryos in water of low pH. Canadian Journal of Zoology 63:2649-2656.

----. 1986. Effects of low $\mathrm{pH}$ and other chemical variables on the local distribution of amphibians. Copeia 1986:454-466.

FREDA, J., and D. H. TAYLOR. 1992. Behavioral response of amphibian larvae to acidic water. Journal of Herpetology 26:429-433.

GABOR, C. R., AND R. G. JAEGER. 1995. Resource quality affects the agonistic behaviour of territorial salamanders. Animal Behavior 49:71-79.

GERENA, C. 2001. Smarter but smaller: competition and regulatory uncertainty pose challenges for West Virginia's coal producers. Region Focus 5:13-21.

GERGITS, W. F., AND R. G. JAEGER. 1990. Site attachment by the red-backed salamander, Plethodon cinereus. Journal of Herpetology 24:91-93.

GIBBS, J. P. 1998a. Amphibian movements in response to forest edges, roads, and streambeds in southern New England. Journal of Wildlife Management 62:584-589. 
GIBBS, J.P. 1998b. Distribution of woodland amphibians along a forest fragmentation gradient. Landscape Ecology 13:263-268.

GILLIAM, F. S. 1998. Will the forests ever grow back? The Highlands Voice September, 1998. $3 \mathrm{pp}$.

GORE, J. A. 1983. The distribution of Desmognathine larvae (Amphibia: Plethodontidae) in coal surface mine impacted streams of the Cumberland Plateau, USA. Journal of Freshwater Ecology 2:13-23.

GREEN, N. B., AND T. K. PAULEY. 1987. Amphibians and reptiles in West Virginia. Univ. of Pittsburgh Press, Pittsburgh. 241 p.

GRIFFITH, D. M., AND R. H., WIDMANN. 2003. Forest statistics for West Virginia: 1989 and 2000. United States Department of Agriculture, Forest Service. Newtown Square, Pennsylvania. $119 \mathrm{p}$.

GRIZZELL, R. A., Jr. 1949. The hibernation site of three snakes and a salamander. Copeia 1949:231-232.

GROVER, M. C. 1998. Influence of cover and moisture on abundances of the terrestrial salamanders Plethodon cinereus and Plethodon glutinosus. Journal of Herpetology 32:489497.

HAERING, K. C., W. L. DANIELS, AND J. A. ROBERTS. 1993. Changes in mine soil properties resulting from overburden weathering. Journal of Environmental Quality 22:194-200.

HAIRSTON, SR. N. G. 1987. Community ecology and salamander guilds. Cambridge University Press, New York, New York. 230 pp.

HALL, J.D., M.L. MURPHY, AND R.S. AHO. 1978. An improved design for assessing impacts of watershed practices on small streams. Verhandlungen der Internationalen Vereinigung fur Theoretische und Angewandte Limnologie 20: 1359-1365.

HAMILTON, M. S. 2002. Effects of developmental activities on streamside salamander communities in Boone County, West Virginia. M. S. Thesis. Marshall University, Huntington, West Virginia. $81 \mathrm{pp}$.

HARPOLE, D. N., AND C. A. HAAS. 1999. Effects of seven silvicultural treatments on terrestrial salamanders. Forest Ecology and Management. 114:349-356.

HARTMAN, K. J., M. J. KALLER, AND J. HOWELL. (in review). Valley-fills influence aquatic macroinvertebrate communities. Hydrobiologia.

HAWKINS, C. P., M. L. MURPHY, N. H. ANDERSON, AND M. A. WILZBACH. 1983. Density of fish and salamanders in relation to riparian canopy and physical habitat in streams of the northwestern United States. Canadian Journal of Fisheries and Aquatic Sciences 40:11731185. 
HEDRICK, J., AND L. RAS. 2002. Determination of aquatic impacts resulting from valley fill construction. Research, Environmental, and Industrial Consultants, Inc. Cool Ridge, West Virginia. 2002 West Virginia Surface Mine Drainage Task Force Symposium Papers http://www.wvu.edu/ agexten/landrec/02ppridx.htm 4 pp.

HERRINGTON, R. E., AND J. H. LARSEN. 1985. Current status, habitat requirements and management of the Larch Mountain salamander Plethodon larselli Burns. Biological Conservation. 34:169-179.

HINKLE, C. R., W. C. MCCOMB, AND S. J. MARCUS, JR. 1989. Mixed mesophytic forest. Chapter 14, in W. H. Martin, ed. The Biotic Communities of the Southeastern U. S. Wiley Publishing Co., New York.

HOLOMUZKI, J. R. 1991. Macrohabitat effects on egg deposition and larval growth, survival, and instream dispersal in Ambystoma barbouri. Copeia 1991:687-694.

HOMYACK, J. D. 1999. Effects of pasture streambank fencing on reptile and amphibian communities in southwestern Pennsylvania. M. S. Thesis. California University of Pennsylvania, California, Pennsylvania.

HORNE, M. T., AND W. A. DUNSON. 1995. The interactive effects of low pH, toxic metals, and DOC on a simulated temporary pond community. Environmental Pollution 89:155-161.

HUCKABEE, J. W., C. P. GOODYEAR, and R. D. JONES. 1975. Acid rock in the Great Smokies: unanticipated impact of aquatic biota of road construction in regions of sulfide mineralization. Transaction of the American Fisheries Society 1975:677-684.

JAMES, F. C., AND H. H. SHUGART. 1970. A quantitative method of habitat description. Audobon Field Notes 24:727-736.

JONES, K. B. 1986. Amphibians and reptiles. Pages 267-290 in Cooperrider, A. Y., J. B. Raymond, and H. R. Stardt, Eds. Inventory and monitoring of wildlife habitat. United States Department of the Interior, Bureau of Land Management Service Center, Denver, Colorado. $858 \mathrm{p}$.

JUNG, R. E., S. DROEGE, J. R. SAUER, AND R. B. LANDY. 2000. Evaluation of terrestrial and streamside salamander monitoring techniques at Shenandoah National Park. Environmental Monitoring and Assessment 63:65-79.

KING, J., AND J. SKOUSEN. 2003. Tree survival on a mountaintop surface mine in West Virginia. Paper presented at the 2003 National Meeting of the American Society of Mining and Reclamation and the $9^{\text {th }}$ billings Land Reclamation Symposium, Billing, Montana, June 3-6, 2003. Published by American Society of Mine Reclamation, Lexington, Kentucky.

KRZYSIK, A. J. 1979. Resource allocation, coexistence, and the niche structure of a streambank salamander community. Journal of Environmental Quality. Ecological Monograph. 1979:173-194. 
KUCKEN, D. J., J. S. DAVIS, J. W. PETRANKA, AND C. K. SMITH. 1994. Anakeesta stream acidification and metal contamination: effects on a salamander community. Journal of Environmental Quality 23:1311-1317.

LOEB, P. 1997. Shear madness: Environmentalists predict that in two decades half the peaks of southern West Virginia's skyline might vanish. U.S. News \& World Report, August 11, 1997. 7 pp.

LONG, L. E., L. S. SAYLOR, and M. E. SOULE. 1995. A pH/UV-B synergism in amphibians. Conservation Biology 9:1301-1303.

LOWE, W. H., AND D. T. BOLGER. 2002. Local and landscape-scale predictors of salamander abundance in New Hampshire headwater streams. Conservation Biology 16:183-193.

MARSH, D. M. AND P. B. PEARMAN. 1997. Effects of habitat fragmentation on the abundance of two species of leptodactylid frogs in an Andean montane forest. Conservation Biology 11:1323-1328.

MARTIN, T. E., C. PAINE, C. J. CONWAY, W. M. HOCKACHKA, P. ALLEN, AND W. JENKINS. 1997. BBIRD Field Protocol. USGS, Biological Resources Division, Montana Cooperative Fish and Wildlife Research Unit, Missoula, Montana.

MATHEWS, R. C. JR., and E. L. MORGAN. 1982. Toxicity of Anakeesta leachates to shovel nosed salamanders, Great Smoky Mountains National Park. Journal of Environmental Quality 11:102-106.

MIDDELKOOP, J., T. WATTS, AND M. SCHORR. 1998. Acid mine drainage and its effects on physicoche mical conditions and salamander populations in a Cumberland Plateau stream. Journal of the Tennessee Academy of Science 73:36.

MITCHELL, J. C. 1999. Amphibian diversity in three montane streams with different levels of acidity, Shenandoah National Park, Virginia. Banisteria 14:28-35.

MURCIA, C. 1995. Edge effects in fragmented forests: implications for conservation. Trends in Ecology and Evolution. 10(2): 58-62.

MURPHY, M. L., AND J. D. HALL. 1981. Varied effects of clear-cut logging on predators and their habitat in small streams of the Cascade Mountains, Oregon. Canadian Journal of Fisheries and Aquatic Sciences 38:137-145.

MUSHINSKY, H. R. 1975. Selection of substrate $\mathrm{pH}$ by salamanders. The American Midland Naturalist 93:440-442.

MYERS, C. W., AND W. D. KLIMSTRA. 1963. Amphibians and reptiles of an ecologically disturbed (strip-mined) area in southern Illinois. American Midland Naturalist 70:127-132. 
NELSON, R. L., M. L. MCHENRY, AND W. S. PLATTS. 1991. Mining. In Influences of Forest and Rangeland Management on Salmonid Fishes and Their Habitats. Meehan, W. R. (ed.). American Fisheries Society Special Publication 19:425-427.

NORLAND, M. R. 2000. Use of mulches and soil stabilizers for land reclamation. In R. I. Barnhisel, R. G. Darmody, and W. L. Daniels (eds.). Reclamation of Drastically Disturbed Lands, pp. 645-666. American Society of Agronomy, Inc., Madison.

NOSS, R. F., AND B. CSUTI. 1997. Habitat fragmentation. In G. K. Meffe, C. R. Carroll, and Contributors. Principles of Conservation Biology, pp. 269-304. Sinauer Associates, Inc. Publishers, Sunderland, Massachusetts.

OHIO ENVIRONMENTAL PROTECTION AGENCY. 2002. Technical report: Ohio's primary headwater streams: fish and amphibian assemblages. Division of Surface Water, Columbus. $28 \mathrm{pp}$.

OLIVER, C. D., AND B. C. LARSON. 1996. Forest stand dynamics. Update edition. John Wiley $\&$ Sons, Inc. New York, New York. 520 p.

PAIS, R. C., S. A. BONNEY, AND W. C. MCCOMB. 1988. Herpetofaunal species richness and habitat associations in an eastern Kentucky forest. Proceedings of the Annual Conference of the Southeastern Association of Fish and Wildlife Agencies 42:448-455.

PAULEY, T. K., AND M. LITTLE. 1998. A new technique to monitor larval and juvenile salamanders in stream habitats. Banisteria 12:32-36.

PEARMAN, P. B. 1997. Correlates of amphibian diversity in an altered landscape of Amazonian Ecuador. Conservation Biology 11:1211-1225.

PECHMANN, J. H. K., D. E. SCOTT, R. D. SEMLITSCH, J. P. CALDWELL, L. J. VITT, AND J. W. GIBBONS. 1991. Declining amphibian populations in perspective: Natural fluctuations and human impacts. Science 253:892-895.

PERISON, D., J. PHELPS, C. PAVEL, AND R. KELLISON. 1997. The effects of timber harvest in a South Carolina blackwater bottomland. Forest Ecology and Management. 90:171-185.

PETRANKA, J. W. 1998. Salamanders of the United States and Canada. Smithsonian Institute Press, Washington. 587 pp.

PETRANKA, J. W., M. P. BRANNON, M. E. HOPEY, AND C. K. SMITH. 1994. Effects of timber harvesting on low elevation populations of southern Appalachian salamanders. Forest Ecology and Management. 67:135-147.

PETRANKA, J. W., M. E. ELDRIDGE, AND K. E. HALEY. 1993. Effects of timber harvesting on southern Appalachian salamanders. Conservation Biology. 7:363-370.

PHELPS, J. P., AND R. A. LANCIA. 1995. Effects of a clearcut on the herpetofauna of a South Carolina bottomland swamp. Brimleyana 22:31-45. 
PIERCE, B. A. 1993. The effects of acid precipitation on amphibians. Ecotoxicology 2:65-77.

PIERCE, B. A. AND D. K. WOOTEN. 1992. Genetic variation in tolerance of amphibians to low pH. Journal of Herpetology 26:422-429.

PLASS, W. T. 2000. History of surface mining reclamation and associated legislation. In R. I. Barnhisel, R. G. Darmody, and W. L. Daniels (eds.). Reclamation of Drastically Disturbed Lands, pp. 433-459. American Society of Agronomy, Inc., Madison.

PLASTER, E. J. 1997. Soil science and management. $3^{\text {rd }}$ Edition. Delmar Publishers, Albany. $402 \mathrm{p}$.

PORTER, K. R., AND D. E. HAKANSON. 1976. Toxicity of mine drainage to embryonic and larval boreal toads (Bufonidae: Bufo boreas). Copeia. 2:327-331.

POUGH, F. H. 1974. Natural daily temperature acclimation of eastern red efts, Notophthalmus $v$. viridescens. Comparative Biochemistry and Physiology 47A:71-78.

-----. 1976. Acid precipitation and embryonic mortality of spotted salamanders, Ambystoma maculatum. Science 192:68-70.

POUGH, F. H., R. M. ANDREWS, J. E. CADLE, M. L. CRUMP, A.H. SAVITZKY, AND K. D. WELLS. 2001. Herpetology. $2^{\text {nd }}$ Edition. Prentice Hall. Upper Saddle River, New Jersey. $612 \mathrm{pp}$.

POUGH, F. H., E. M. SMITH, D. H. RHODES, AND A. COLLAZO. 1987. The abundance of salamanders in forest stands with different histories of disturbance. Forest Ecology and Management. 20:1-9.

POWELL, R. 2000a. Panelist comments and discussion. Aquatic resources: comments by Mr. Powell. In Aquatic ecosystem enhancement at mountaintop mining symposium, Charleston, West Virginia. January 12, 2000. 2 pp.

-----. 2000b. An evaluation of aquatic ecosystem enhancement at four mountaintop mining / valley fill sites in West Virginia. In Aquatic ecosystem enhancement at mountaintop mining symposium, Charleston, West Virginia. January 12, 2000. 5 pp.

POWER, M. E., R. J. STOUT, C. E. CUSHING, P. P. HARPER, F. R. HAUSER, W. J. MATTHEWS, P. B. MOYLE, B. STATZNER, AND I. R. WAIS DE BADGEN. 1988. Biotic and abiotic communities. Journal of the North American Benthological Society 7:125.

READ, J. L. 1992. Influence of habitats, climate, grazing, and mining on terrestrial vertebrates at Olympic Dam, south Australia. Journal of Rangeland Management. 14(2):143-156.

REDMOND, W. H. 1980. Notes on the distribution and ecology of the black mountain dusky salamander Desmognathus welteri Barbour (Amphibia: Plethodontidae) in Tennessee. Brimleyana 4:123-131. 
RESEARCH ENVIRONMENTAL AND INDUSTRIAL CONSULTANTS, INC. 2000. Amphibian utilization of sediment control structures compared to a natural vernal pool located on mine permitted areas in southern West Virginia. Conducted for Pen Coal Corporation, Dunlow, West Virginia. 28 pp.

RICHARDS, I. G., J. P. PALMER, AND P. A. BARRATT. 1993. The Reclamation of Former Coal Mines and Steelworks: Studies in Environmental Science Volume 56. Elsevier, Amsterdam. 718 p.

RILEY, C. V. 1952. An evaluation of reclaimed coal strip mined lands as wildlife habitat. Unpubl. Ph. D. Diss., The Ohio State University, Columbus. 289 pp.

-----. 1960. The ecology of water areas as sociated with coal strip-mined lands in Ohio. The Ohio Journal of Science 60:106-121.

ROBEL, R. J., J. N. BRIGGS, A. D. DAYTON, AND L. C. HULBERT. 1970. Relationships between visual obstruction measurements and weight of grassland vegetation. Journal of Range Management 23:295-297.

ROBERTS, J. A., W. L. DANIELS, J. C. BELL, AND J. A. BURGER. 1988a. Early stages of mine soil genesis in a southwest Virginia spoil lithosequence. Soil Science Society of America Journal 52:716-723.

-----. 1988b. Early stages of mine soil genesis as affected by topsoiling and organic amendments. Soil Science Society of America Journal 52:730-738.

ROCCO, G. L., AND R. P. BROOKS. 2000. Abundance and distribution of a stream plethodontid salamander assemblage in 14 ecologically dissimilar watersheds in the Pennsylvania Central Appalachians. Final Report. Report No. 2000-4. Penn State Cooperative Wetlands Center, Forest Resources Laboratory, Pennsylvania State Univ., State College. Prepared for U.S. Environmental Protection Agency Region III. 82 p.

RODEWALD, A.D., AND R.H. YAHNER. 1999. Effects of forest-management and landscape composition on woodland salamanders. Northeast Wildlife 54:45-54.

ROSS, B., T. FREDERICKSEN, E. ROSS, W. HOFFMAN, M. L. MORRISON, J. BEYEA, M. B. LESTER, B. N. JOHNSON, AND N. J. FREDERICKSEN. 2000. Relative abundance and species richness of herpetofauna in forest stands in Pennsylvania. Forest Science 46:139146.

ROUDEBUSH, R. E. 1988. A behavioral assay for acid sensitivity in two desmognathine species of salamanders. Herpetologica 44:392-395.

ROWE, C. L., W. J. SADINSKI, and W. A. DUNSON. 1992. Effects of acute and chronic acidification on three larval amphibians that breed in temporary ponds. Archives of Environmental Contamination and Toxicology 23:339-350. 
SADINSKI, W. J. and W. A. DUNSON. 1992. A multilevel study of effects of low pH on amphibians of temporary ponds. Journal of Herpetology 26:413-422.

SIH, A., L. B. KATS, and R. D. MOORE. 1992. Effects of predatory sunfish on the density, drift, and refuge use of stream salamander larvae. Behavioral Ecology and Sociobiology 23:335339.

SATTLER, P., AND N. REICHENBACH. 1998. The effects of timbering on Plethodon hubrichti: short-term effects. Journal of Herpetology. 32:399-404.

SAUGEY, D. A., G. A. HEIDT, AND D. R. HEATH. 1988. Utilization of abandoned mine drifts and fracture caves by bats and salamanders: unique subterranean habitat in the Ouachita Mountains. In: R.C. Szaro, K.E. Severson, and D.R. Patton. Eds. Management of amphibians, reptiles, and mammals in North America. Technical Report RM-166. U.S. Department of Agriculture, Forest Service, Rocky Mountain Forest and Range Experiment Station, Fort Collins, Colorado.

SCHLOTZHAUER, S. D., AND R. C. LITTELL. 1997. SAS system for Elementary Statistical Analysis. SAS Institute, Inc., Cary.

SCHNOES, R. S., AND S. R. HUMPHREY. 1987. Terrestrial plant and wildlife communities on phosphate-mined lands in central Florida. Bulletin of the Florida State Museum, Biological Sciences. 30(3):53-116.

SCIULLI, A. G., G. P. BALLOCK, AND K. K. WU. 1986. Environmental approach to coal refuse disposal. Mining Engineering 38:181-186.

SENCINDIVER, J. C., AND J. T. AMMONS. 2000. Minesoil genesis and classification. In R. I. Barnhisel, R. G. Darmody, and W. L. Daniels (eds.). Reclamation of Drastically Disturbed Lands, pp. 595-613. American Society of Agronomy, Inc., Madison.

SHAFFER, L. L. 1991. Pennsylvania Amphibians and Reptiles. Pennsylvania Fish Commission. Harrisburg, Pennsylvania. $161 \mathrm{pp}$.

SKOUSEN, J., AND C. E. ZIPPER. 1996. Revegetation species and practices. In Virginia Cooperative Extension Publication 460-120. Reclamation Guidelines for Surface Mined Land in Southwestern Virginia, pp. 1-18. Virginia Tech, Blacksburg.

SLICK, B. M., AND W. R. CURTIS. 1985. A guide for the use of organic materials as mulches in reclamation of coal minesoils in the eastern United States. USDA-FS GTR NE 98. United States Government Printing Office, Washington, D. C.

SMITH, H. C. 1977. Height of the tallest saplings in 10-year-old Appalachian hardwood clearcuts. Research Paper N3-381. Upper Darby, PA: USDA Forest Service.

SOKAL, R. R., AND F. J. ROHLF. 1995. Biometry. 3rd ed. W. H. Freeman and Co., New York. 
SPURGEON, A. B. 2002. Comparison of herpetofaunal species composition and response to edge on the Camp Dawson Collective Training Area, Preston County, West Virginia. M. S. Thesis. West Virginia University, Morgantown, West Virginia.

STARNES, L. B. 1985. Aquatic community response to techniques utilized to reclaim eastern U.S. coal surface mine-impacted streams. In J. A. Gore (ed.). The Restoration of Rivers and Streams: Theories and Experience, pp. 193-222. Butterworth, Boston.

STARNES, L., AND D. C. GASPER. 1995. Effects of surface mining on aquatic resources in North America. Fisheries 20:20-26.

STATISTICAL ANALYSIS SOFTWARE INSTITUTE. 1990. SAS Users' Guide. Version 6. SAS Institute, Cary.

----. 2000. The SAS system for windows: statistical analysis system 8.1. SAS Institute, Cary, North Carolina.

STEBBINS, R.C., AND N.W. COHEN. 1995. A natural history of amphibians. Princeton University Press. Princeton, New Jersey. 316 pp.

STEPHENS, K. M., A. J. SEXSTONE, J. C. SENCINDIVER, J. G. SKOUSEN, AND K. A. THOMAS. 2001. Microbial indicators of minesoil quality in southern West Virginia. Paper presented at the 2001 National Meeting of the American Society for Surface Mining and Reclamation, Albuquerque, New Mexico, June 3-7, 2001.

STRAUSBAUGH, P. D., AND E. L., CORE. 1977. Flora of West Virginia. 2nd edition. Seneca Books, Inc., Morgantown, West Virginia.

TAUB, F.B. 1961. Red-backed salamanders in soil. Ecology. 42:681-698.

THOMAS, D., AND I. JANSEN. 1985. Soil development in coal mine spoils. Journal of Soil and Water Conservation 40:439-442.

THOMAS, K. A., J. C. SENCINDIVER, J. G. SKOUSEN, AND J. M. GORMAN. 2000. Soil horizon development on a mountaintop surface mine in southern West Virginia. Green Lands Summer:41-51.

TORBERT, J. L., AND J. A. BURGER. 2000. Forest land reclamation. In R. I. Barnhisel, R. G. Darmody, and W. L. Daniels (eds.). Reclamation of Drastically Disturbed Lands, pp. 371398. American Society of Agronomy, Inc., Madison.

TOY, T. J., AND J. P. BLACK. 2000. Topographic reconstruction: The theory and practice. In R. I. Barnhisel, R. G. Darmody, and W. L. Daniels (eds.). Reclamation of Drastically Disturbed Lands, pp. 41-75. American Society of Agronomy, Inc., Madison.

TURNER, L. J., AND D. K. FOWLER. 1981. Utilization of surface mine ponds in east Tennessee by breeding amphibians. U. S. Fish and Wildlife Service Report FWS/OBS-81/08. 13 pp. 
TWIGG, L. E., AND B. J. FOX. 1991. Recolonization of regenerating open forest by terrestrial lizards following sand mining. Australian Journal of Ecology 16:137-148.

UNITED STATES BUREAU OF RECLAMATION. 1977. Design of small dams. United States Department of the Interior, Water Resource Technical Publication. United States Government Printing Office, Washington, D.C. 860 p.

UNITED STATES ENVIRONMENTAL PROTECTION AGENCY. 1976. Erosion and sediment control, surface mining in the eastern U.S. EPA Technological Transfer Publication, EPA625/3-76-006. United States Government Printing Office, Washington, D.C.

-----. 2003. Mountaintop mining / valley fills in Appalachia: draft programmatic environmental impact statement. June 2003, EPA 9-03-R-00013, Environmental Protection Agency Region 3, Philadelphia, Pennsylvania.

-----. 2000. Mountaintop mining / valley fill environmental impact statement. Preliminary draft January 2001, EPA/903/R-00/013EPA Region 3, Philadelphia, Pennsylvania.

VAN HORNE, B. 1983. Density as a misleading indicator of habitat quality. Journal of Wildlife Management 47:893-901.

VAN HOUTEN, D. G., F. D. CHILDS, C. C. TEETS, R. ESTEPP, AND F. A. DOONAN. 1981. Soil survey of Kanawha County, West Virginia. O - 254-032. United States Department of Agriculture, Soil Conservation Service. United States Government Printing Office, Washington, D.C. 111 pp.

VOGT, R. C., AND R. L. HINE. 1982. Evaluation of techniques for assessment of amphibian and reptile populations in Wisconson. Pages 201-217 in N. J. Scott, editor. Herpetological communities. U. S. Fish and Wildlife Service Resource Report No. 13.

VOLLERS, M. 1999. Miners fight to keep their towns on the map. UTNE Reader. Nov/Dec: 6973.

WALDICK, R. 1997. Effects of forestry practices on amphibian populations in eastern North America. In M. Green (ed.). Amphibians in Decline: Canadian Studies of a Global Problem, pp. 191-205. Society for the Study of Amphibians and Reptiles, St. Louis.

WALDRON, J. L., C. K. DODD JR., AND J. D. CORSER. 2003. Leaf litterbags: factors affecting capture of stream-dwelling salamanders. Applied Herpetology: 1:23-36.

WALLACE, B. 2000a. Overview of first order watersheds. In Aquatic ecosystem enhancement at mountaintop mining symposium, Charleston, West Virginia. January 12, 2000. 4 pp.

WALLACE, B. 2000b. Panelist comments and discussion. Aquatic resources: comments by Dr. Wallace. In Aquatic ecosystem enhancement at mountaintop mining symposium, Charleston, West Virginia. January 12, 2000. 2 pp. 
WATERS, T. F. 1995. Sediment in streams: sources, biological effects, and control. American Fisheries Society, Bethesda, Maryland. 251 p.

WATSON, W. D. 1996. Preserving natural environments on coal lands at minimum cost. Energy Journal 17:91-127.

WELSH, JR. H.H., AND A.J. LIND. 1988. Old growth forests and the distribution of the terrestrial herpetofauna. Pages 439-455 In R.C. Szaro, K.E. Severson, and D.R. Patton. Eds. Management of amphibians, reptiles, and mammals in North America. Technical Report RM-166. U.S. Department of Agriculture, Forest Service, Rocky Mountain Forest and Range Experiment Station, Fort Collins Colorado.

-----. 1992. Population ecology of two relictual salamanders from the Klamath Mountains of Northwestern California. Pages 419-437 in D. R. McCullough and R. H. Barrett, editors. Wildlife 2001: populations. Elsevier Applied Science, London, UK.

WELSH, JR. H. H., AND L. M. OLLIVIER. 1998. Stream amphibians as indicators of ecosystem stress: a case study from California's Redwoods. Ecological Applications 8:1118-1132.

WELSH, JR. H. H., L. M. OLLIVIER, AND D. G. HANKIN. 1997. A habitat-based design for sampling and monitoring stream amphibians with an illustration from Redwood National Park. Northwestern Naturalist 78:1-16.

WILLIAMS, T. 2001. Mountain madness: West Virginia's coal companies are altering the state's very surface, and no one seems to have the power - or the will - to stop them. Audubon, May-June:36-43.

WOLF, B. L. 1994. Soil survey of Boone County, West Virginia. United States Soil Conservation Service, Guyan Soil Conservation District, United States Government Printing Office, Washington, D.C., USA.

WOLMAN, M. G., AND L. B. LEOPOLD. 1957. River floodplains: some observations on their formations. United States Geological Service Professional Paper 282C. Printing Office, Washington, D.C. $115 \mathrm{pp}$.

WOOD, P. B., J. W. EDWARDS, AND C. A. WEAKLAND. JANUARY 2001. Terrestrial vertebrate (breeding songbird, raptor, small mammal, herpetofaunal) of forested and reclaimed sites. Final report submitted to EIS steering committee. Morgantown, West Virginia. $149 \mathrm{pp}$.

WYMAN, R. L. 1990. What's happening to the amphibians? Conservation Biology 4:350-354.

YAHNER, R. H. 1988. Changes in wildlife communities near edges. Conservation Biology 2:333339.

YAHNER, R.H., W.C. BRAMBLE, AND W.R. BYRNES. 2001. Effect of vegetation maintenance of an electric transmission right-of-way on reptile and amphibian populations. Journal of Arboriculture. 27:24-28. 
ZAR, J. H. 1999. Biostatistical analysis. $4^{\text {th }}$ edition. Prentice Hall, Upper Saddle River, New Jersey.

ZIMMERMAN, B. L. AND M. T. RODRIGUEZ. 1990. Frogs, snakes, and lizards of the INPAWWF reserves near Manaus, Brazil. Pages 426-454 in A. H. Gentry (ed.). Four Neotropical Rainforests. Yale University Press, New Haven, Connecticut.

ZUG, G. R., L. J. VITT, AND J. P. CALDWELL. 2001. Herpetology: an introductory biology of amphibians and reptiles. $2^{\text {nd }}$ edition. Academic Press, San Diego, California. 


\section{VITA}

\section{Jennifer Mravintz Williams}

Jen Williams was born near Pittsburgh, Pennsylvania and spent her childhood in Cheswick, Pennsylvania as the youngest of 6 children. She graduated from Deer Lakes High School in 1992 and started Gannon University in fall of that year. She graduated with a B.S in Biology and worked for a year as a microbiology and virology laboratory assistant in Erie, Pennsylvania. After spending a summer in Vermont working as a Natural Resource Instructor at the Green Mountain Conservation Camp, she started her M. S. thesis at The Pennsylvania State University under the advisement of Dr. Hoagy Schaadt in fall of 1997. Her research focused on terrestrial salamander relative abundance in a mature, secondgrowth forest and an old growth forest in Pennsylvania. She graduated in May of 2000 with an M. S. in Wildlife and Fisheries Science. She then spent another summer working in Vermont before starting a job as a Research Technologist for the National Park Service. In January of 2001, she began her tenure at West Virginia University under the direction of Dr. Petra Bohall Wood. She graduated from WVU in December of 2003 with her Ph. D. in Forest Resource Science (emphasis on Wildlife / Herpetology). She is currently living in West Palm Beach, Florida, where she patiently awaits the job of her dreams. 